Prepared in cooperation with the National Park Service

Nutrient Budgets, Marsh Inundation Under Sea-Level

Rise Scenarios, and Sediment Chronologies for the Bass Harbor Marsh Estuary at Acadia National Park

Open-File Report 2014-1031 



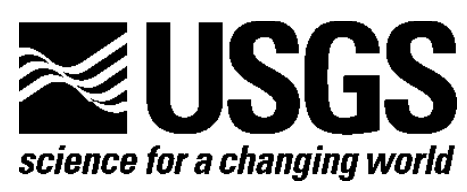

Prepared in cooperation with the National Park Service

\section{Nutrient Budgets, Marsh Inundation Under Sea-Level Rise Scenarios, and Sediment Chronologies for the Bass Harbor Marsh Estuary at Acadia National Park}

By Thomas G. Huntington, Charles W. Culbertson, Christopher Fuller, Patricia Glibert, and Luke Sturtevant

Open-File Report 2014-1031

U.S. Department of the Interior

U.S. Geological Survey 


\section{U.S. Department of the Interior \\ SALLY JEWELL, Secretary}

\section{U.S. Geological Survey \\ Suzette M. Kimball, Acting Director}

U.S. Geological Survey, Reston, Virginia: 2014

For more information on the USGS-the Federal source for science about the Earth, its natural and living resources, natural hazards, and the environment-visit http://www.usgs.gov or call 1-888-ASK-USGS

For an overview of USGS information products, including maps, imagery, and publications, visit http://www.usgs.gov/pubprod

To order this and other USGS information products, visit http://store.usgs.gov

Any use of trade, firm, or product names is for descriptive purposes only and does not imply endorsement by the U.S. Government.

Although this information product, for the most part, is in the public domain, it also may contain copyrighted materials as noted in the text. Permission to reproduce copyrighted items must be secured from the copyright owner.

Suggested citation:

Huntington, T.G., Culbertson, C.W., Fuller, Christopher, Glibert, Patricia, and Sturtevant, Luke, 2014, Nutrient budgets, marsh inundation under sea-level rise scenarios, and sediment chronologies for the Bass Harbor Marsh estuary at Acadia National Park: U.S. Geological Survey Open-File Report 2014-1031, 108 p., http://dx.doi.org/10.3133/ofr20141031.

ISSN 2331-1258 (online) 


\section{Acknowledgments}

The authors are grateful for the support they received from several people that contributed to the successful completion of this study. Staff at Acadia National Park (David Manski and William Gawley) helped facilitate this study by providing logistical support and meteorological, hydrologic, and waterquality data.

Staff at the U.S. Geological Survey (Nick Stasulis, Laura Flight, and Anthony Underwood) installed and maintained the flow gaging station at the estuary outlet and assisted with quality assurance and processing of the continuously collected water-temperature and specific conductance data. Nick Stasulis (U.S. Geological Survey) provided the technical expertise for design and implementation of the collection of bathymetric data and the postprocessing of these data so that they could be incorporated into a geographic information system. Laurel Larsen (U.S. Geological Survey) provided equipment and assistance with efforts to measure nitrate concentrations continuously at the gage outlet. Karen Anderson (National Park Service) provided historical aerial photographs that were used to assess estuary-channel widening. Edward Stets, Marc Zimmerman, Charles Schalk, Greg Stewart, and Pam Lombard (all of the U.S. Geological Survey) provided technical reviews that strengthened various sections of the report. 


\section{Contents}

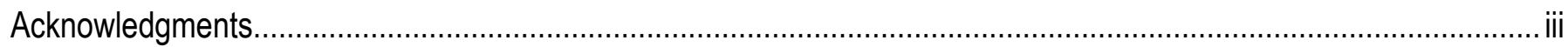

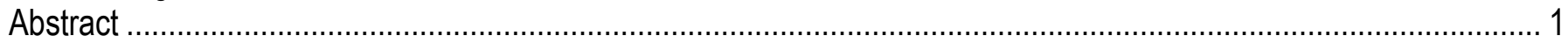

Introduction and Background on Nutrient Cycling in Coastal Estuaries ............................................................. 2

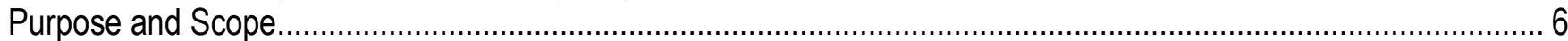

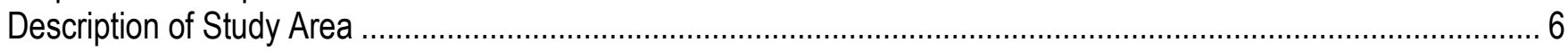

Methods of Measurement, Sampling, and Laboratory Analysis ........................................................................ 8

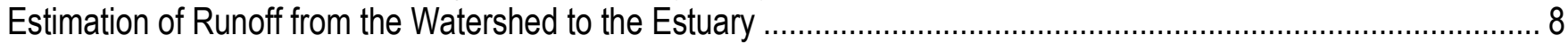

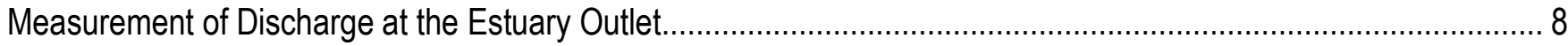

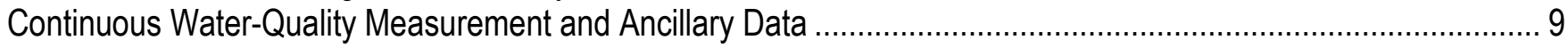

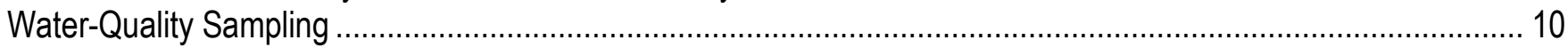

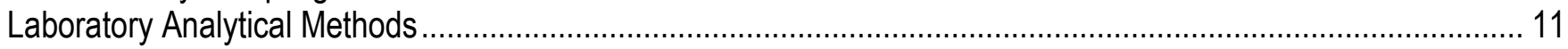

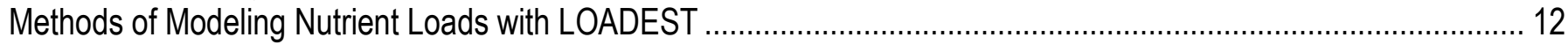

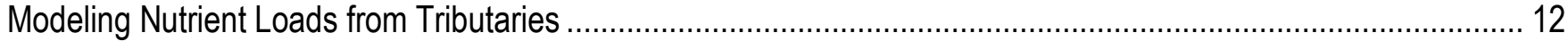

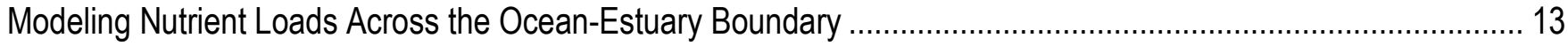

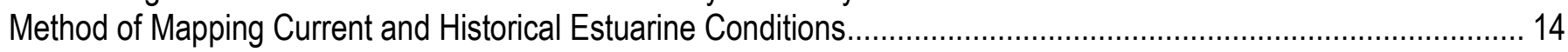

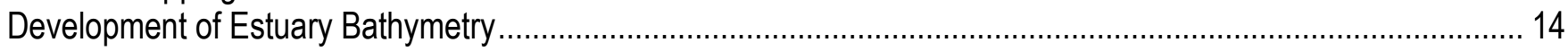

Estimating Effects of Sea-Level Rise on Area of Inundation in Bass Harbor Marsh............................................. 16

Estimating Channel Widening within Bass Harbor Marsh ............................................................................. 17

Methods of Sediment Coring and Analysis for Determination of Mass and Sediment Accumulation Rates................. 18

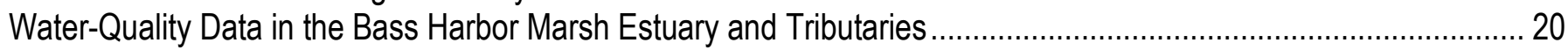

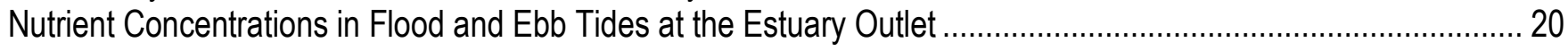

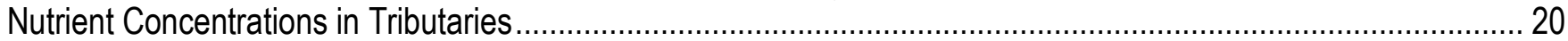

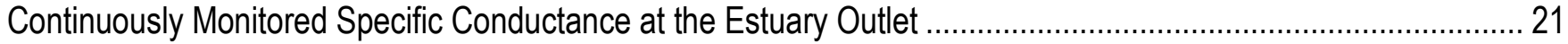

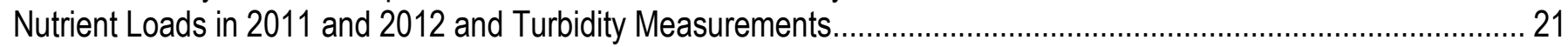

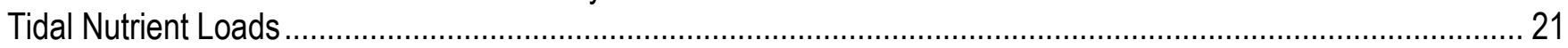

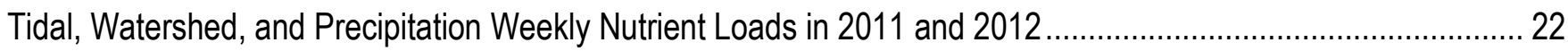

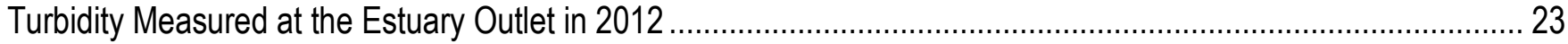

Tidal, Watershed, and Precipitation Seasonal Total Nutrient Loads in 2011 and 2012 ….................................. 23

Sea-Level Rise and Historical Changes in the Bass Harbor Marsh Estuary ......................................................... 24

Projected Changes in Inundated Area and Estuary Volume Under Three SLR Scenarios...................................... 24

Historical Changes in Estuary Area Based on a GIS Analysis of Aerial Photographs ........................................... 25

Bass Harbor Marsh Estuary and Marsh Surface Cores: Summary of ${ }^{210} \mathrm{~Pb}$ Chronology and Mass Accumulation

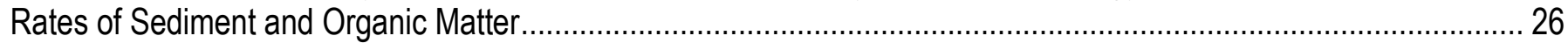

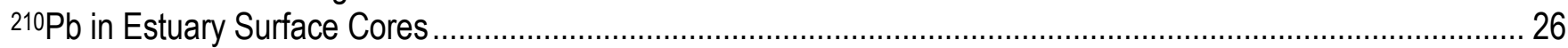

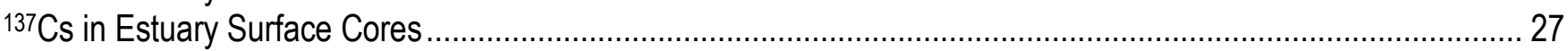

Estimating Mass Accumulation Rates Using Estuary Sediment Cores …………………………………….... 27

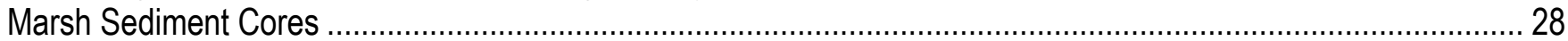

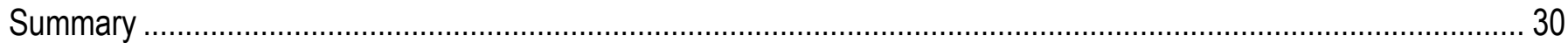

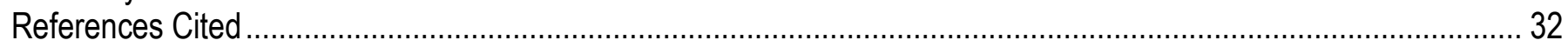




\section{Figures}

Figure 1. Map showing Mount Desert Island, Maine, in shaded relief, including the general location of Bass Harbor Marsh as an inset.

Figure 2. Map showing of Bass Harbor Marsh watershed, including watershed outline, streams, roads, Bass Harbor Marsh, and sampling locations, Mount Desert Island, Maine.

Figure 3. Map showing subwatersheds and tributaries delineated at sampling stations, Bass Harbor Marsh watershed, Mount Desert Island, Maine.

Figure 4. Map showing major vegetation types, streams, and roads at Bass Harbor Marsh watershed, Mount Desert Island, Maine.

Figure 5. Map showing Bass Harbor Marsh estuary, fringing marsh, and surrounding area in shaded relief, Mount Desert Island, Maine. Locations where sediment cores were collected in 2009 and 2011 are also shown. . 42 Figure 6. Graphs showing A, specific conductance and B, water temperature recorded during an ebb tide at 10:15 on June 21, 2012, at Bass Harbor Marsh estuary outlet, Mount Desert Island, Maine. Measurements were recorded in the middle of three depth strata: the surface, middle, and bottom depth intervals. Error bars indicate the variability of the measurements that was observed over about 1 minute. The actual variability was not recorded but was estimated to be about \pm 10 percent of the value shown.

Figure 7. Graphs showing recordings taken on at ebb tide at 11:00 on October 3, 2012, at Bass Harbor Marsh estuary outlet, Mount Desert Island, Maine, of A, specific conductance, B, water temperature, and C, turbidity, and on a flood tide recorded at 14:15 on October 3, 2012, of D, specific conductance, E, water temperature, and F, turbidity. Measurements were recorded in the middle of three depth strata: the surface, middle and bottom depth intervals. Error bars indicate the variability of the measurements that was observed over about 1 minute. The actual variability was not recorded but was estimated to be about \pm 10 percent of the value shown.

Figure 8. Map showing the track of the acoustic Doppler current profiler/Global Positioning System (ADCP/GPS) that was towed in the Bass Harbor Marsh estuary, Mount Desert Island, Maine, on July 5, 2012. The track is colorcoded showing the depth of water in the estuary at 14:01 at each point.

Figure 9. Graph showing water elevation (in reference to the North American Vertical Datum of 1988 (NAVD 88)) at the three reference points used to establish the slope of the water surface during the bathymetric survey, Bass Harbor Marsh estuary, Mount Desert Island, Maine. RM3, TBM101, and TBM102 are vertical reference control points in the Bass Harbor Marsh estuary. RM3 is a lagbolt in a bolder near the estuary outlet, TBM101 is a lagbolt $310.9 \mathrm{~m}$ upstream of the estuary outlet and TBM102 is vertically-set rebar $592.2 \mathrm{~m}$ upstream of the estuary outlet.

Figure 10. Graph showing concentrations of nitrate and ammonium in flood and ebb tides at the Bass Harbor Marsh estuary outlet, Mount Desert Island, Maine, during 2011 and 2012. Box and whisker plots show median, 25th and 75 th quartiles. Whiskers show the last observation within $1.5 \mathrm{x}$ the interquartile range (IQR, distance between the 25th and 75th quartiles). The " $x$ " symbol indicates observations between 1.5 and 3.0 times the IQR and the "o" symbol indicates observations greater than 3 times the IQR. Numbers at the top of the graph are the total number of samples analyzed for the indicated constituent in flood or ebb tide.

Figure 11. Graph showing concentrations of total dissolved nitrogen (TDN) and total dissolved organic nitrogen (TON) in flood and ebb tides at the Bass Harbor Marsh estuary outlet, Mount Desert Island, Maine, during 2011 and 2012. Box and whisker plots show median, quartiles, 10th and 90th deciles, outliers, and the number of samples analyzed. Numbers at the top of the graph are the total number of samples analyzed for the indicated constituent in flood or ebb tide.

Figure 12. Graph showing concentrations of inorganic nitrogen in tributaries draining into the Bass Harbor Marsh estuary, Mount Desert Island, Maine, in 2012 and 2012. Box and whisker plots show median, 25th and 75th quartiles. Whiskers show the last observation within $1.5 \mathrm{x}$ the interquartile range (IQR, distance between the 25 th 
and 75th quartiles). The "x" symbol indicates observations between 1.5 and 3.0 times the IQR and the "o" symbol indicates observations greater than 3 times the IQR. Numbers at the top of the graph are the total number of samples analyzed for the indicated constituent in flood or ebb tide.

Figure 13. Graph showing total dissolved nitrogen and dissolved organic nitrogen in tributaries draining into the Bass Harbor Marsh estuary, Mount Desert Island, Maine. Box and whisker plots show median, 25th and 75th quartiles. Whiskers show the last observation within $1.5 \mathrm{x}$ the interquartile range (IQR, distance between the 25th and 75th quartiles). The "x" symbol indicates observations between 1.5 and 3.0 times the IQR and the "o" symbol indicates observations greater than 3 times the IQR. Numbers at the top of the graph are the total number of samples analyzed for the indicated constituent in flood or ebb tide.

Figure 14. Graph showing total dissolved phosphorus (TDP) in tributaries draining into the Bass Harbor Marsh estuary, Mount Desert Island, Maine. Box and whisker plots show median, 25th and 75th quartiles. Whiskers show the last observation within $1.5 x$ the interquartile range (IQR, distance between the 25 th and 75 th quartiles). The " $x$ " symbol indicates observations between 1.5 and 3.0 times the IQR and the "o" symbol indicates observations greater than 3 times the IQR. Numbers at the top of the graph are the total number of samples analyzed for the indicated constituent in flood or ebb tide.

Figure 15. Graphs showing A, continuous specific conductance and water temperature at the Bass Harbor Marsh estuary outlet, Mount Desert Island, Maine, during June through September 2011, and B, discharge at Otter Creek and precipitation at McFarland Hill, Mount Desert Island, Maine, during June through September 2011.

Figure 16. Graphs showing A, continuous specific conductance and water temperature at the Bass Harbor Marsh estuary outlet, Mount Desert Island, Maine, during June through September 2012, and B, discharge at Otter Creek and precipitation at McFarland Hill, Mount Desert Island, Maine, during April through September 2012.

Figure 17. Graphs showing A, calculated tidal load of ammonium across the ocean-estuary boundary of Bass Harbor Marsh estuary in 2011 and tidal elevation in Bar Harbor, Maine; B, calculated tidal load of ammonium and daily precipitation recorded at McFarland Hill on Mount Desert Island, Maine; and C, calculated net tidal exchange (expressed as load, $\mathrm{kg}$ nitrogen per tide) during each tidal cycle (flood tide minus following ebb tide).....

Figure 18. Graphs showing A, calculated tidal load of ammonium across the ocean-estuary boundary for Bass Harbor Marsh estuary in 2012 and tidal elevation in Bar Harbor, Maine; B, calculated tidal load of ammonium and daily precipitation recorded at McFarland Hill on Mount Desert Island, Maine; and C, calculated net tidal exchange (expressed as load, $\mathrm{kg}$ nitrogen per tide) during each tidal cycle (flood tide minus following ebb tide).....

Figure 19. Graphs showing A, calculated tidal load of nitrate across the ocean-estuary boundary for Bass Harbor Marsh estuary in 2011 and tidal elevation in Bar Harbor, Maine; B, calculated tidal load of nitrate and daily precipitation recorded at McFarland Hill on Mount Desert Island, Maine; and C, calculated net tidal exchange (expressed as load, kg nitrogen per tide) during each tidal cycle (flood tide minus following ebb tide).....

Figure 20. Graphs showing A, calculated tidal load of nitrate across the ocean-estuary boundary for Bass Harbor Marsh estuary in 2012 and tidal elevation in Bar Harbor, Maine; B, calculated tidal load of nitrate and daily precipitation recorded at McFarland Hill on Mount Desert Island, Maine; and C, calculated net tidal exchange (expressed as load, $\mathrm{kg}$ nitrogen per tide) during each tidal cycle (flood tide minus following ebb tide)..................59 Figure 21. Graphs showing A, calculated tidal load of total dissolved nitrogen across the ocean-estuary boundary for Bass Harbor Marsh estuary in 2011 and tidal elevation in Bar Harbor, Maine; B, calculated tidal load of total dissolved nitrogen and daily precipitation recorded at McFarland Hill on Mount Desert Island, Maine; and C, calculated net tidal exchange (expressed as load, kg nitrogen per tide) during each tidal cycle (flood tide minus following ebb tide).

Figure 22. Graphs showing A, calculated tidal load of total dissolved nitrogen across the ocean-estuary boundary for Bass Harbor Marsh estuary in 2012 and tidal elevation in Bar Harbor, Maine; B, calculated tidal load of total dissolved nitrogen and daily precipitation recorded at McFarland Hill on Mount Desert Island, Maine; and C, calculated net tidal exchange (expressed as load, kg nitrogen per tide) during each tidal cycle (flood tide minus following ebb tide)...... 
Figure 23. Graphs showing A, calculated tidal load of total dissolved phosphorus across the ocean-estuary boundary for Bass Harbor Marsh estuary in 2011 and tidal elevation in Bar Harbor, Maine; B, calculated tidal load of phosphorus and daily precipitation recorded at McFarland Hill on Mount Desert Island, Maine; and C, calculated net tidal exchange (expressed as load, kg phosphorus per tide) during each tidal cycle (flood tide minus following ebb tide).

Figure 24. Graphs showing A, calculated tidal load of total dissolved phosphorus across the ocean-estuary boundary for Bass Harbor Marsh estuary in 2012 and tidal elevation in Bar Harbor, Maine; B, calculated tidal load of phosphorus and daily precipitation recorded at McFarland Hill on Mount Desert Island, Maine; and C, calculated net tidal exchange (expressed as load, kg phosphorus per tide) during each tidal cycle (flood tide minus following ebb tide).

Figure 25. Graph showing weekly ammonium $\left(\mathrm{NH}_{4}\right)$ inputs to the estuary (from precipitation, watershed runoff, and ebb tides) and exports from the Bass Harbor Marsh estuary (flood tide) in 2011, Mount Desert Island, Maine.

Figure 26. Graph showing weekly ammonium $\left(\mathrm{NH}_{4}\right)$ inputs to the estuary (from precipitation, watershed runoff, and ebb tides) and exports from the Bass Harbor Marsh estuary (flood tide) in 2012, Mount Desert Island,

Maine

Figure 27. Graph showing weekly nitrate $\left(\mathrm{NO}_{3}\right)$ inputs to the estuary (from precipitation, watershed runoff, and ebb tides) and exports from the Bass Harbor Marsh estuary (flood tide) in 2011, Mount Desert Island, Maine....... 66 Figure 28. Graph showing weekly nitrate $\left(\mathrm{NO}_{3}\right)$ inputs to the estuary (from precipitation, watershed runoff, and ebb tides) and exports from the Bass Harbor Marsh estuary (flood tide) in 2012, Mount Desert Island, Maine....... 67 Figure 29. Graph showing weekly phosphorus inputs to the estuary (from precipitation, watershed runoff, and ebb tides) and exports from the Bass Harbor Marsh estuary (flood tide) in 2011, Mount Desert Island, Maine.

Figure 30. Graph showing weekly phosphorus inputs to the estuary (from precipitation, watershed runoff, and ebb tides) and exports from the Bass Harbor Marsh estuary (flood tide) in 2012, Mount Desert Island, Maine...

Figure 31. Graph showing weekly total dissolved nitrogen inputs to the estuary (from precipitation, watershed runoff, and ebb tides) and exports from the Bass Harbor Marsh estuary (flood tide) in 2011, Mount Desert Island, Maine.

Figure 32. Graph showing weekly total dissolved nitrogen inputs to the estuary (from precipitation, watershed runoff, and ebb tides) and exports from the Bass Harbor Marsh estuary (flood tide) in 2012, Mount Desert Island, Maine.

Figure 33. Graph showing ratio of weekly nitrate $\left(\mathrm{NO}_{3}\right)$ and ammonium $\left(\mathrm{NH}_{4}\right)$ inputs in runoff and precipitation to tidal inputs during summer 2011, Bass Harbor Marsh estuary, Mount Desert Island, Maine.................................. 72 Figure 34. Graph showing ratio of weekly nitrate $\left(\mathrm{NO}_{3}\right)$ and ammonium $\left(\mathrm{NH}_{4}\right)$ inputs in runoff and precipitation to tidal inputs during summer 2012, Bass Harbor Marsh estuary, Mount Desert Island, Maine. 73

Figure 35. Graph showing ratio of weekly total dissolved nitrogen and phosphorus inputs in runoff and precipitation to tidal inputs during summer 2011, Bass Harbor Marsh estuary, Mount Desert Island, Maine.

Figure 36. Graph showing ratio of weekly total dissolved nitrogen and phosphorus inputs in runoff and precipitation to tidal inputs during summer 2012, Bass Harbor Marsh estuary, Mount Desert Island, Maine. 75

Figure 37. Graphs showing A, turbidity measured at the Bass Harbor Marsh estuary outlet and discharge measured at Otter Creek, Mount Desert Island, Maine, during 2012, and B, turbidity and flow velocity measured at the Bass Harbor Marsh estuary outlet. Positive velocity indicates ebb tide and negative velocity indicates flood tide.

Figure 38. Bathymetric map showing Bass Harbor Marsh estuary, Mount Desert Island, Maine, at high tide at 14:01, July 7, 2012.

Figure 39. Maps showing the predicted inundated areas within the Bass Harbor Marsh watershed, Mount Desert Island, Maine, at A, mean higher high water (MHHW) following 50-, 100-, and 200-centimeter (cm) sea-level rise (SLR), B, mean lower low water (MLLW) following 50-, 100-, and 200-cm SLR, and C, MHHW following 200-cm 
SLR with the 95-percent-upper- and lower-limit confidence bounds. The thick black line delineates the current [2013] channel boundary.

Figure 40. Photograph showing Bass Harbor Marsh estuary channel delineation from historical georeferenced aerial photographs, Mount Desert Island, Maine. Colors indicate extent of the estuary channel in years shown. ... 81 Figure 41. A, Graph showing total lead-210 (210Pb) and radium-226 (226Ra) activities, in becquerels per gram $(\mathrm{Bq} / \mathrm{g})$, in relation to depth in sediment core BHM.01 from Bass Harbor Marsh, Mount Desert Island, Maine. The location of the sediment core is shown in figure 5. Horizontal error bars depict 1-sigma uncertainty in the measured activity based on counting statistics. Vertical error bars depict depth range of sample interval. B, Graph showing natural logarithm of unsupported $210 \mathrm{~Pb}$ activity in relation to cumulative dry sediment mass (grams per square centimeter) in sediment core BHM.01 from Bass Harbor Marsh, Mount Desert Island, Maine. The corresponding depth, in centimeters, is shown on right hand axis.

Figure 42. A, Graph showing sediment deposition date in relation to depth based on the sediment mass accumulation rate estimated from lead-210 (210Pb) activity using the constant rate of supply (CRS) method in sediment core BHM.01 from Bass Harbor Marsh, Mount Desert Island, Maine. The location of the sediment core is shown in figure 5. B, Graph showing CRS method sediment mass accumulation rate (MAR), in grams of dry sediment per square centimeter per year, in relation to depth. Error bars represent 1-sigma propagated uncertainty in model MARs in sediment core BHM.01 from Bass Harbor Marsh, Mount Desert Island, Maine.

Figure 43. Graph showing cesium-137 (137Cs) activity, in becquerels per gram, in relation to depth in sediment core BHM.01. The location of the sediment core is shown in figure 5. Horizontal error bars depict 1-sigma uncertainty in measured activity based on counting statistics. Vertical error bars depict depth range of sample interval. Dashed line depicts method detection limit for 137Cs.

Figure 44. A, Graph showing total lead-210 (210Pb) and radium-226 (226Ra) activities, in becquerels per gram $(\mathrm{Bq} / \mathrm{g})$, in relation to depth in sediment core BHM.02 from Bass Harbor Marsh, Mount Desert Island, Maine. The location of the sediment core is shown in figure 5. Horizontal error bars depict 1-sigma uncertainty in measured activity based on counting statistics. Vertical error bars depict depth range of sample interval. B, Graph showing sediment deposition date in relation to depth based on the sediment mass accumulation rate estimated from $210 \mathrm{~Pb}$ using the CRS (constant rate of supply) method in sediment core BHM.02 from Bass Harbor Marsh, Mount Desert Island, Maine.

Figure 45. A, Graph showing total lead-210 (210Pb) and radium-226 (226Ra) activities, in becquerels per gram $(\mathrm{Bq} / \mathrm{g})$, in relation to depth in sediment core BHM.03 from Bass Harbor Marsh, Mount Desert Island, Maine. The location of the sediment core is shown in figure 5 . Horizontal error bars depict 1-sigma uncertainty in measured activity based on counting statistics. Vertical error bars depict depth range of sample interval. B, Graph showing sediment deposition date in relation to depth based on the sediment mass accumulation rate estimated from $210 \mathrm{~Pb}$ using the constant rate of supply (CRS) method in sediment core BHM.03 from Bass Harbor Marsh, Mount Desert Island, Maine.

Figure 46. $A$, Graph showing total lead-210 $(210 \mathrm{~Pb})$ and radium-226 $\left({ }^{226} \mathrm{Ra}\right)$ activities, in becquerels per gram $(\mathrm{Bq} / \mathrm{g})$, in relation to depth in sediment core BHM.04 from Bass Harbor Marsh, Mount Desert Island, Maine. The location of the sediment core is shown in figure 5. Horizontal error bars depict 1-sigma uncertainty in measured activity based on counting statistics. Vertical error bars depict depth range of sample interval. $B$, Graph showing sediment deposition date in relation to depth based on the sediment mass accumulation rate estimated from ${ }^{210} \mathrm{~Pb}$ using the constant rate of supply (CRS) method in sediment core BHM.04 from Bass Harbor Marsh, Mount Desert

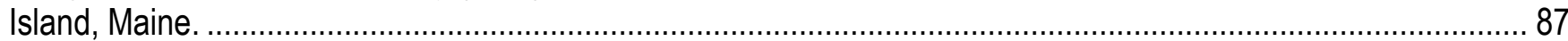

Figure 47. Graphs showing comparisons of A, lead-210 (210Pb) constant rate of supply (CRS) dates in relation to depth at the four core sites within the Bass Harbor Marsh estuary, and B, mass accumulation rates from the CRS method in relation to depth at the four core sites within the Bass Harbor Marsh estuary, Mount Desert Island, Maine. 
Figure 48. Graphs showing comparisons of A, unsupported lead-210 (210Pb) activity, in becquerels per gram $(\mathrm{Bq} / \mathrm{g})$, in relation to depth at the four core sites within the Bass Harbor Marsh estuary, Mount Desert Island, Maine; and $\mathrm{B}$, cesium $(137 \mathrm{Cs})$ activity, in becquerels per gram $(\mathrm{Bq} / \mathrm{g})$, in relation to depth at the four core sites within the Bass Harbor Marsh estuary. Dashed line depicts method detection limit for 137Cs.

Figure 49. Graph showing organic matter content, expressed as the fraction of total dry sediment mass as determined from loss on ignition (LOI), in relation to depth for the four core sites within the Bass Harbor Marsh estuary, Mount Desert Island, Maine.

Figure 50. Graphs showing A, total lead-210 (210Pb) and radium-226 (226Ra) activities, in becquerels per gram $(\mathrm{Bq} / \mathrm{g})$, in relation to depth in marsh surface sediment core BHM.S1 from Bass Harbor Marsh, Mount Desert Island, Maine (horizontal error bars depict 1-sigma uncertainty in measured activity based on counting statistics; vertical error bars depict depth range of sample interval); the location of the sediment core is shown in figure 5 ; $\mathrm{B}$, cesium137 (137Cs) activity, in becquerels per gram (Bq/g), in relation to depth; $\mathrm{C}$, sediment deposition date in relation to depth based on the sediment mass accumulations estimated from 210Pb using the constant rate of supply (CRS) method; D, sediment mass accumulation rate (MAR), in grams of dry sediment per square centimeter per year $(\mathrm{g} / \mathrm{cm} 2 / \mathrm{yr})$, in relation to depth; and $\mathrm{E}$, organic matter content, expressed as the fraction of total dry sediment mass as determined from loss on ignition (LOI), in relation to depth.

Figure 51. Graphs showing A, total lead-210 $(210 \mathrm{~Pb})$ and radium-226 (226Ra) activities, in becquerels per gram $(\mathrm{Bq} / \mathrm{g})$, in relation to depth in marsh surface sediment core BHM.S2 from Bass Harbor Marsh, Mount Desert Island, Maine (horizontal error bars depict 1-sigma uncertainty in measured activity based on counting statistics; the location of the sediment core is shown in figure 5 ; vertical error bars depict depth range of sample interval); $B$, cesium-137 ( $\left.{ }^{137} \mathrm{Cs}\right)$ activity, in becquerels per gram (Bqi/g), in relation to depth. (C) Sediment deposition date in relation to depth based on the sediment mass accumulations estimated from ${ }^{210} \mathrm{~Pb}$ using the constant rate of supply (CRS) method. (D) Sediment mass accumulation rate (MAR), in grams of dry sediment per square centimeter per year $\left(\mathrm{g} / \mathrm{cm}^{2} / \mathrm{yr}\right)$, in relation to depth. (E) Organic matter content, expressed as the fraction of total dry sediment mass as determined from loss on ignition (LOI), in relation to depth.

Figure 52. Graphs showing (A) Total lead-210 (210Pb) and radium-226 (226Ra) activities, in becquerels per gram $(\mathrm{Bq} / \mathrm{g})$, in relation to depth in marsh surface sediment core BHM.S3. The location of the sediment core is shown in figure 5. Horizontal error bars depict 1-sigma uncertainty in measured activity based on counting statistics. Vertical error bars depict depth range of sample interval. (B) 137Cs activity, in becquerels per gram (Bq/g), in relation to depth. (C) Sediment deposition date in relation to depth based on the sediment mass accumulations estimated from $210 \mathrm{~Pb}$ using the constant rate of supply (CRS) method. (D) Sediment mass accumulation rate (MAR), in grams of dry sediment per square centimeter per year $(\mathrm{g} / \mathrm{cm} 2 / \mathrm{yr})$, in relation to depth. (E) Organic matter content, expressed as the fraction of total dry sediment mass as determined from loss on ignition (LOI), in relation to depth.

Figure 53. Graphs showing $(\mathrm{A})$ Total lead-210 (210Pb) and radium-226 (226Ra) activities, in becquerels per gram $(\mathrm{Bq} / \mathrm{g})$, in relation to depth in marsh surface sediment core BHM.S4a. The location of the sediment core is shown in figure 5. Horizontal error bars depict 1-sigma uncertainty in measured activity based on counting statistics. Vertical error bars depict depth range of sample interval. (B) 137Cs activity, in becquerels per gram (Bq/g), in relation to depth. (C) Sediment deposition date in relation to depth based on the sediment mass accumulations estimated from $210 \mathrm{~Pb}$ using the constant rate of supply (CRS) method. (D) Sediment mass accumulation rate (MAR), in grams of dry sediment per square centimeter per year $(\mathrm{g} / \mathrm{cm} 2 / \mathrm{yr})$, in relation to depth. (E) Organic matter content, expressed as the fraction of total dry sediment mass as determined from loss on ignition (LOI), in relation to depth.

Figure 54. Graphs showing (A) lead-210 (210Pb) 210Pb and radium-226 (226Ra) activities, in becquerels per gram $(\mathrm{Bq} / \mathrm{g})$, in relation to depth in marsh surface sediment core BHM.S4b. The location of the sediment core is shown in figure 5. Horizontal error bars depict 1-sigma uncertainty in measured activity based on counting statistics. Vertical error bars depict depth range of sample interval. (B) 137Cs activity, in becquerels per gram 
$(\mathrm{Bq} / \mathrm{g})$, in relation to depth. (C) Sediment deposition date in relation to depth based on the sediment mass accumulations estimated from 210Pb using the constant rate of supply (CRS) method. (D) Sediment mass accumulation rate (MAR), in grams of dry sediment per square centimeter per year $(\mathrm{g} / \mathrm{cm} 2 / \mathrm{yr})$, in relation to depth. (E) Organic matter content, expressed as the fraction of total dry sediment mass as determined from loss on ignition (LOI), in relation to depth.

Figure 55. Graphs showing (A) Unsupported lead-210 (210Pb) activity, in becquerels per gram $(\mathrm{Bq} / \mathrm{g})$, in relation to depth, in centimeters $(\mathrm{cm})$, in the five marsh surface sediment cores. (B) Cesium-137 (137Cs)activity, in becquerels per gram $(\mathrm{Bq} / \mathrm{g})$, in relation to depth; $\mathrm{C}$, sediment deposition date in relation to depth based on the sediment mass accumulations estimated from 210Pb using the CRS (constant rate of supply) method; D, sediment mass accumulation rate (MAR), in grams of dry sediment per square centimeter per year in relation to year $(\mathrm{g} / \mathrm{cm} 2 / \mathrm{yr}) ; E$, organic matter MAR in relation to depth; $F$, inorganic sediment mass accumulation rate in relation to depth; and G, organic matter content, expressed as the fraction of total dry sediment mass as determined from loss on ignition (LOI), in relation to depth.

\section{Tables}

Table 1. Surface-water-streamgaging and water-quality-monitoring stations in Bass Harbor Marsh watershed in Mount Desert Island, Maine.

Table 2. Constituents and minimum reporting limits for water-quality-sample analyses conducted as part of this study.

Table 3. Location of sediment cores in the estuary and fringing marsh, date of core collection, and vegetation at coring sites in Bass Harbor Marsh, Mount Desert Island, Maine.

Table 4. Summer nutrient budget data for Bass Harbor Marsh estuary in Mount Desert Island, Maine, in 2011 and 2012.

Table 5. Projected changes in estuary area and in water volume associated with 50-, 100-, and 200-centimeter sea-level rise at mean higher high water and mean lower low water at Bass Harbor Marsh estuary, Mount Desert Island, Maine.

Table 6. Historical changes in estuary channel and marsh areas based on geo-referenced aerial photographs, Bass Harbor Marsh estuary, Mount Desert Island, Maine. 102

Table 7. Summary of total sediment mass accumulation rates (MAR) and sedimentation rates for the cores collected from the estuary in 2009 at Bass Harbor Marsh, Mount Desert Island, Maine....................................... 103 Table 8. Summary of sediment mass accumulation rates (MAR), for the cores collected from the marsh surface in 2011 at Bass Harbor Marsh, Mount Desert Island, Maine. 104

Table 9. Summary of sedimentation rates for the cores collected from the marsh surface at Bass Harbor Marsh,

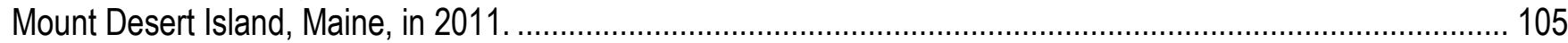

Table 10. LOADEST-selected regression equations for the indicated tributary or tidal load............................ 106 Table 11. Number of observations and selected model statistics from LOADEST regression model runs. ....... 107 Table 12. Mean loads and associated 95-percent confidence intervals based on the chosen adjusted maximum likelihood estimate regression model for tributary or tidal fluxes. 108 


\section{Conversion Factors, Datum, and Abbreviations}

SI to Inch/Pound

\begin{tabular}{|c|c|c|}
\hline Multiply & By & To obtain \\
\hline \multicolumn{3}{|c|}{ Length } \\
\hline centimeter $(\mathrm{cm})$ & 0.3937 & inch (in.) \\
\hline millimeter (mm) & 0.03937 & inch (in.) \\
\hline meter $(\mathrm{m})$ & 3.281 & foot $(\mathrm{ft})$ \\
\hline kilometer $(\mathrm{km})$ & 0.6214 & mile (mi) \\
\hline meter $(\mathrm{m})$ & 1.094 & yard (yd) \\
\hline \multicolumn{3}{|c|}{ Area } \\
\hline hectare (ha) & 2.471 & acre \\
\hline square kilometer $\left(\mathrm{km}^{2}\right)$ & 247.1 & acre \\
\hline square centimeter $\left(\mathrm{cm}^{2}\right)$ & 0.001076 & square foot $\left(\mathrm{ft}^{2}\right)$ \\
\hline square centimeter $\left(\mathrm{cm}^{2}\right)$ & 0.1550 & square inch $\left(\mathrm{ft}^{2}\right)$ \\
\hline hectare (ha) & 0.003861 & square mile $\left(\mathrm{mi}^{2}\right)$ \\
\hline square kilometer $\left(\mathrm{km}^{2}\right)$ & 0.3861 & square mile $\left(\mathrm{mi}^{2}\right)$ \\
\hline \multicolumn{3}{|c|}{ Volume } \\
\hline cubic meter $\left(\mathrm{m}^{3}\right)$ & 6.290 & barrel (petroleum, 1 barrel $=42$ gal $)$ \\
\hline liter (L) & 33.82 & ounce, fluid (fl. oz) \\
\hline liter (L) & 2.113 & pint $(\mathrm{pt})$ \\
\hline $\operatorname{liter}(\mathrm{L})$ & 1.057 & quart (qt) \\
\hline liter (L) & 0.2642 & gallon (gal) \\
\hline cubic meter $\left(\mathrm{m}^{3}\right)$ & 264.2 & gallon (gal) \\
\hline cubic centimeter $\left(\mathrm{cm}^{3}\right)$ & 0.06102 & cubic inch $\left(\right.$ in $\left.^{3}\right)$ \\
\hline cubic meter $\left(\mathrm{m}^{3}\right)$ & 35.31 & cubic foot $\left(\mathrm{ft}^{3}\right)$ \\
\hline cubic meter $\left(\mathrm{m}^{3}\right)$ & 1.308 & cubic yard $\left(\mathrm{yd}^{3}\right)$ \\
\hline cubic meter $\left(\mathrm{m}^{3}\right)$ & 0.0008107 & acre-foot (acre-ft) \\
\hline \multicolumn{3}{|c|}{ Flow rate } \\
\hline cubic meter per second $\left(\mathrm{m}^{3} / \mathrm{s}\right)$ & 35.31 & cubic foot per second $\left(\mathrm{ft}^{3} / \mathrm{s}\right)$ \\
\hline meter per second $(\mathrm{m} / \mathrm{s})$ & 3.281 & foot per second $(\mathrm{ft} / \mathrm{s})$ \\
\hline \multicolumn{3}{|c|}{ Mass } \\
\hline $\operatorname{gram}(\mathrm{g})$ & 0.03527 & ounce, avoirdupois (oz) \\
\hline kilogram (kg) & 2.205 & pound avoirdupois (lb) \\
\hline
\end{tabular}


Temperature in degrees Celsius $\left({ }^{\circ} \mathrm{C}\right)$ may be converted to degrees Fahrenheit $\left({ }^{\circ} \mathrm{F}\right)$ as follows:

$$
{ }^{\circ} \mathrm{F}=\left(1.8 x^{\circ} \mathrm{C}\right)+32
$$

Temperature in degrees Fahrenheit $\left({ }^{\circ} \mathrm{F}\right)$ may be converted to degrees Celsius $\left({ }^{\circ} \mathrm{C}\right)$ as follows:

$$
{ }^{\circ} \mathrm{C}=\left({ }^{\circ} \mathrm{F}-32\right) / 1.8
$$

Vertical coordinate information is referenced to the North American Vertical Datum of 1988 (NAVD 88).

Horizontal coordinate information is referenced to the North American Datum of 1983 (NAD 83).

Elevation, as used in this report, refers to distance above the vertical datum.

Specific conductance is given in microsiemens per centimeter at 25 degrees Celsius $\left(\mu \mathrm{S} / \mathrm{cm}\right.$ at $\left.25^{\circ} \mathrm{C}\right)$.

Concentrations of chemical constituents in water are given either in milligrams per liter (mg/L) or micrograms per liter $(\mu \mathrm{g} / \mathrm{L})$.

${ }^{210} \mathrm{~Pb},{ }^{226} \mathrm{Ra}$, and ${ }^{137} \mathrm{Cs}$ activities are given in becquerels per gram $(\mathrm{Bq} / \mathrm{g})$.

Mass accumulation rates are given in grams per square centimeter per year $\left(\mathrm{g} / \mathrm{cm}^{2} / \mathrm{yr}\right)$.

Sediment accumulation rates are given in centimeter per year $(\mathrm{cm} / \mathrm{yr})$.

\title{
Abbreviations
}

\author{
ADCP acoustic Doppler current profiler \\ AMLE adjusted maximum likelihood estimate \\ ANP Acadia National Park \\ BHM Bass Harbor Marsh \\ CF:CS constant flux-constant sedimentation method \\ CRS constant rate of supply [determined by the ${ }^{210} \mathrm{~Pb}$ dating method] \\ DIN dissolved inorganic nitrogen \\ DON dissolved organic nitrogen \\ EMCC eastern Maine coastal current \\ GOM Gulf of Maine \\ GPS global positioning system \\ IDW inverse distance weighting \\ LED light-emitting diode \\ lidar light detection and ranging \\ LOI loss on ignition \\ MAR mass accumulation rate \\ MDI Mount Desert Island \\ MHHW mean higher high water \\ MLLW mean lower low water \\ NADP National Atmospheric Deposition Program \\ NAVD88 North American Vertical Datum 1988 \\ NEC Northeast Creek \\ NIST National Institute of Standards and Technology \\ NOAA National Oceanographic and Atmospheric Administration \\ NPS National Park Service \\ NETN Northeast Temperate Trends Network \\ NTU nephelometric turbidity units \\ NWIS National Water Information System \\ SLR sea-level rise \\ TDN total dissolved nitrogen \\ TDP total dissolved phosphorus \\ TN total nitrogen \\ TON total organic nitrogen \\ USGS U.S. Geological Survey
}




\title{
Nutrient Budgets, Inundation Under Sea-Level Rise Scenarios, and Sediment Chronologies for the Bass Harbor Marsh Estuary at Acadia National Park
}

\author{
By Thomas G. Huntington, ${ }^{1}$ Charles W. Culbertson, ${ }^{1}$ Christopher Fuller, ${ }^{1}$ Patricia Glibert, ${ }^{2}$ and \\ Luke Sturtevant ${ }^{1}$
}

\begin{abstract}
Eutrophication in the Bass Harbor Marsh estuary on Mount Desert Island, Maine, is an ongoing problem manifested by recurring annual blooms of green macroalgae species, principally Enteromorpha prolifera and Enteromorpha flexuosa, blooms that appear in the spring and summer. These blooms are unsightly and impair the otherwise natural beauty of this estuarine ecosystem. The macroalgae also threaten the integrity of the estuary and its inherent functions. The U.S. Geological Survey and Acadia National Park have collaborated for several years to better understand the factors related to this eutrophication problem with support from the U.S. Geological Survey and National Park Service Water Quality Assessment and Monitoring Program. The current study involved the collection of hydrologic and water-quality data necessary to investigate the relative contribution of nutrients from oceanic and terrestrial sources during summer 2011 and summer 2012. This report provides data on nutrient budgets for this estuary, sedimentation chronologies for the estuary and fringing marsh, and estuary bathymetry. The report also includes data, based on aerial photographs, on historical changes from 1944 to 2010 in estuary surface area and data, based on surface-elevation details, on changes in marsh area that may accompany sea-level rise.

The LOADEST regression model was used to calculate nutrient loads into and out of the estuary during summer 2011 and summer 2012. During these summers, tidal inputs of ammonium to the estuary were more than seven times greater than the combined inputs in watershed runoff and precipitation. In 2011 tidal inputs of nitrate were about four times greater than watershed plus precipitation inputs, and in 2012 tidal inputs were only slightly larger than watershed plus precipitation inputs. In 2011, tidal inputs of total organic nitrogen were larger than watershed input by a factor of 1.6. By contrast, in 2012 inputs of total organic nitrogen in watershed runoff were much larger than tidal inputs, by a factor of 3.6. During the 2011 and 2012 summers, tidal inputs of total dissolved phosphorus to the estuary were more than seven times greater than inputs in watershed runoff. It is evident that during the summer tidal inputs of inorganic nitrogen and total dissolved phosphorus to the estuary exceed inputs from watershed runoff and precipitation.
\end{abstract}

\footnotetext{
${ }^{1}$ U.S. Geological Survey.

${ }^{2}$ University of Maryland.
} 
Projected sea-level rise associated with ongoing climate warming will affect the area of land within the Bass Harbor Marsh estuary watershed that is inundated during conditions of mean higher high water and during mean lower low water and hence will affect the vegetation and marsh area. Given 100-centimeter sea-level rise, the inundated area would increase from 25.7 hectares at the current condition to 77.5 hectares at mean higher high water and from 21.6 hectares to 26.7 hectares at mean lower low water. Given 50-centimeter sea-level rise, flooding of the entire marsh surface, which currently occurs only under the highest spring tides, would occur on average every other day.

Radioisotope analysis of sediment cores from the estuary indicates that the sediment accumulation rate increased markedly from 1930 to 1980 and was relatively constant ( 0.4 to 0.5 centimeter per year) from 1980 to 2009. Similarly, from 1980 to 2009 there was a consistently high mass accumulation rate of 0.09 to 0.11 grams per square centimeter per year. The sediment accretion rates determined for the five cores collected from the marsh surface (east and west sides of the estuary) in 2011 show generally higher rates of 0.20 to 0.29 centimeter per year for the period between 1980 to 2011 than for the period before 1980, when sediment accretion rates were 0.06 to 0.25 centimeter per year.

The data in this report provide resource managers at Acadia National Park with a baseline that can be used to evaluate future conditions within the estuary. Climate change, sea-level rise, and land-use change within the estuary's watershed may influence nutrient dynamics, sedimentation, and eutrophication, and these potential effects can be studied in relation to the baseline data provided in this report. The Route 102 Bridge in Tremont, Maine is constructed over a sill that controls the amount of tidal flushing by restricting the duration of the flood tide, and structural changes to the bridge could alter tidal nutrient inputs and residence times for watershed and ocean-derived nutrients in the estuary. Ongoing sea-level rise is likely increasing ocean-derived nutrients and their residence time in the estuary on the one hand and decreasing the residence time of watershed-derived nutrients on the other.

\section{Introduction and Background on Nutrient Cycling in Coastal Estuaries}

The U.S. Geological Survey, in cooperation with the National Park Service, conducted a study during summers of 2011 and 2012 to investigate oceanic nutrient inputs into Bass Harbor Marsh estuary. The Resource Management Plan for Acadia National Park (ANP) (Kahl and others, 2000) and the marine and estuarine resources research catalog workshop held at ANP in 2006 identified accelerated rates of freshwater and coastal marine eutrophication as a priority water-quality issue that continues to be one of the park's most substantial resource-management challenges. The U.S. Environmental Protection Agency's national coastal condition report (U.S. Environmental Protection Agency, 2001) lists eutrophic condition as one of the three greatest threats to the health of the Nation's estuaries. In the northeastern United States, about 60 percent of the estuarine area shows a high expression of eutrophic condition (U.S. Environmental Protection Agency, 2001). Previous U.S. Geological Survey (USGS) investigations have demonstrated the susceptibility of ANP' estuaries to elevated nutrient inputs from increasing rural development outside the park's boundaries. In spite of increases in residential development within the Bass Harbor Marsh (BHM) watershed, concentrations of dissolved nitrogen species in surface water tributaries to the estuary have not increased in the last 20 years, yet recurring annual macro-algal blooms continue and are reported to be worsening.

Doering and others (1995) reported that the relative contribution of oceanic sources, compared with the contribution of freshwater sources, of dissolved inorganic (DIN) and total 
nitrogen (TN) to BHM estuary was highly variable. The DIN to TN ratio depended most on the amount of freshwater discharge and the concentration of nitrogen species in freshwater inputs. In the Doering and others (1995) study neither the oceanic nor the freshwater source dominated either DIN or total dissolved nitrogen (TDN). Organic forms of nitrogen typically accounted for greater than 80 percent of total nitrogen inputs from both fresh and marine sources. It is likely that rising sea levels (approximately 18 centimeters $(\mathrm{cm})$ since the early 1900s in this area) have resulted in an increase in oceanic inputs due to the restriction at the estuary outlet and the resulting tidal asymmetry (9- to 10-hour ebb tide and 2- to 3-hour flood tide) in this estuary. The Doering and others (1995) study involved only a few discrete measurements and acknowledged errors averaging about 25 percent, a rate suggesting the need for better quantification with continuous measurements.

Nitrogen enters estuarine ecosystems through atmospheric deposition and through surface water, groundwater, and marine sources. The rates of naturally occurring terrestrial nitrogen cycling have been doubled by human activities, primarily through the burning of fossil fuels (atmospheric deposition), applying of fertilizers, and increasing of septic effluents associated with increasing populations (Nixon, 1995; Vitousek and others, 1997; Boyer and Howarth, 2002). Riverine exports of nitrogen to the near-coastal ocean have also increased with increasing development in the northeastern United States and the Canadian Maritime Provinces (National Research Council, 2000; Howarth, 2008). Nitrogen fixation may be accelerating because of seasurface warming (Karl and others, 2002), thus adding more reactive nitrogen that could enhance tidal inputs. Townsend (1998) has reported that remineralization of organic nitrogen was an important source of dissolved nitrogen in the Gulf of Maine (GOM) so that if climate change increases, the rate of remineralization of more reactive nitrogen in near-coastal ocean waters would also increase. The largest source of nitrogen in tidal-input waters is from the eastern Maine coastal current (EMCC), which flows in a counterclockwise direction in the GOM and from east to west in the ocean off Mount Desert Island and BHM (Pettigrew and others, 1998). The nitrogen in the EMCC is derived primarily from the Scotian Shelf and Northeast Channel waters that enter the GOM from the northeast (Townsend, 1998). Runoff from Saint John River and other rivers to the east of Mount Desert Island contribute nitrogen to the nearshore EMCC. Primary production in the offshore GOM can become nutrient-limited in the summer as nitrogen is depleted in the euphotic zone. However, nitrogen is abundant in deeper waters, and locally tidal mixing, wind, and upwelling from currents can supply surface waters with nitrogen throughout the summer (Sowles, 2001). Climatic changes that alter wind, ocean circulation, and currents could change the magnitude and temporal pattern of nitrogen inputs to estuaries in the GOM.

EMCC waters are relatively enriched in nitrate plus nitrite compared with most waters in the GOM and are thought to contribute to near-shore algal blooms under conditions in which these waters are advected shoreward with strong onshore winds (Townsend and others, 2001). The frequency, spatial extent, and duration of coastal eutrophication and harmful algal blooms have increased greatly in recent decades largely because of increases in nitrogen inputs (Howarth, 2008). Climate projections indicating increasing storm intensity in this region (Bindoff and others, 2007; Nicholls and others, 2007) suggest that nutrient delivery to these nearshore regions of the eastern GOM may increase in association with further climate warming. There is also evidence of increased freshening of continental shelf waters, including the Gulf of Maine (resulting from higher rates of glacial melting, enhanced precipitation, and higher river 
runoff in recent decades); this freshening could affect circulation, vertical stratification, and spring phytoplankton blooms (Ji and others, 2007; Balch and others, 2012).

The general responses of estuaries and coastal ecosystems to excessive nutrient enrichment are widely recognized (Glibert and others, 2010). These responses include increased growth of macroalgae and phytoplankton, subsequent reduction in light penetration leading to loss of seagrass habitat, increased community metabolism, and decreased dissolved oxygen concentrations (Valiela and others 1992; Nixon 1995; Glibert and others, 2008). Algal responses have tended to follow increases in nitrate $\left(\mathrm{NO}_{3}\right)$ plus nitrite $\left(\mathrm{NO}_{2}\right)$ and ammonium $\left(\mathrm{NH}_{4}\right)$, emphasizing nitrogen limitations in tributaries to the Chesapeake Bay (Glibert and others, 2008). Estuarine resources at ANP in other locations such as Northeast Creek (NEC) are also threatened by increasing nutrient enrichment. In NEC, the threats have primarily been associated with air pollution and rapid residential development of the watersheds (Neckles and others 2003). Studies completed by the USGS in the last 15 years have addressed several questions related to the eutrophication susceptibility of estuaries at ANP. The focus of prior research has been on the load of nutrients off the landscape and their effects on the estuarine ecosystem and on the denitrification potential of marsh soils. The completed studies include the following:

1. Quantifying the loads of dissolved nitrogen and phosphorus nutrients from selected tributaries draining previously burned or unburned areas on Mount Desert Island (Nielsen and Kahl, 2007);

2. Predicting the response of the Northeast Creek Estuary ecosystem response to various levels of additional $\mathrm{NO}_{3}$ fertilization (Neckles and others, 2003);

3. Developing the "Acadia National Park Nutrient Load and Estuarine Response Decision Support System" (U.S. Geological Survey, 2013a) to calculate nutrient loading in the Northeast Creek Estuary;

4. Identifying groundwater seeps that contribute to nutrient enrichment of Northeast Creek and BHM estuaries (Culbertson and others, 2007); and

5. Estimating ambient and potential denitrification rates in marsh soils of Northeast Creek and Bass Harbor Marsh watersheds, Mount Desert Island, Maine (Huntington and others, 2012).

Sedimentation within the estuary may contribute to eutrophication by causing shoaling (shallow water) that, in turn, could result in increasing water temperature, reduced stratification and increased light penetration through the water column, and increased phytoplankton growth (Lucas and Cloern, 2002). Estuarine phytoplankton growth is related to seasonal variations in irradiance, temperature, grazing, inputs of nutrients, and freshwater; daily to weekly variations in tidal dynamics, vertical mixing, turbidity, and horizontal transport (Cloern, 1996); and hourly variations in water column depth (Lucas and Cloern, 2002). Sedimentation could also result in an increase in the rate of organic nitrogen mineralization from sediments. Sediment loads across the estuarine-coastal ocean boundary are unknown. Sea-level rise has changed the hydrodynamics that, in turn, have affected residence time for tidal waters and the rate of sedimentation in the estuary. Sea-level rise may also affect the rates of erosion of marsh surfaces and upland banks. Climatic and hydrologic changes may accelerate the rate of the delivery of nitrogen via surface and groundwater and the rate of net mineralization of soil and estuary sediment organic nitrogen (Howarth and others, 2006; Huntington, 2006; Huntington and others, 2009). The likelihood of these potential changes has not been assessed to determine their effects on eutrophication. 
Tidally exported organic matter and biota produced in salt marsh or wetland plant communities can have a profound effect on estuarine productivity, making coastal salt marshes and wetlands among the most productive yet threatened ecosystems in North America. Changes in sediment physicochemical conditions related to nutrient enrichment or to perturbations due to human activity can alter the pattern of plant zonation, whereby highly competitive invasive plant species can displace native plant species. Moreover, these changes can additionally trigger a higher frequency and intensity of nuisance algal blooms in estuarine ecosystems, a key indicator of a system trending toward eutrophication.

While it is reasonable to be concerned with watershed development and increasing nutrient loading from land, a national assessment of the eutrophication status of the Nation's estuaries revealed that many estuaries in Rhode Island, Massachusetts, New Hampshire, and Maine exhibited eutrophic symptoms despite their associations with relatively pristine watersheds (Bricker and others, 1999). These eutrophic symptoms were attributed to the low level of freshwater supply relative to tidal inputs in these systems. Thus, offshore coastal waters may be the major nutrient source for many estuaries where tidal contributions are large relative to freshwater drained from the watershed. Tidal nutrient contributions may be especially important during drought periods when freshwater inputs to estuaries are at a minimum. Drought periods are likely to become more frequent and severe in response to projected climate change (Hayhoe and others, 2007; Anderson and others, 2010).

The exchange of nutrients between estuaries and adjacent near-coastal ocean environments has been the subject of considerable study that has evolved over time (Nixon, 1980; Childers and others, 2000; Tobias and Neubauer, 2009). Early studies suggested that most marsh-estuary complexes were sources of nutrients to the ocean, stimulating productivity in what was known as an "Outwelling Hypothesis," (Nixon, 1980). This hypothesis was patterned after upwelling in oceanic systems, whereby upwelling is an important source of nutrients for oceanic productivity (Childers and others, 2000). As more data became available, it was apparent to estuarine scientists (Childers and others, 2000; Tobias and Neubauer, 2009) that the exchange of nutrients between estuaries and adjacent oceans was complex. Investigators have begun to seek patterns among marsh-estuary complexes in terms of climate, freshwater inputs, basin age, geomorphologic setting, tidal amplitude, and vegetation that might explain nutrient exchanges. High variability in these properties among estuaries has made it difficult to categorize systems as net importers or exporters of nutrients.

Tobias and Neubauer (2009) have reviewed several studies that have reported net nutrient exchanges for estuaries and associated salt marsh ecosystems. In their review of more than 20 salt marsh studies they found 40 percent of the marshes were net annual importers of $\mathrm{NH}_{4}$, 35 percent imported $\mathrm{NO}_{3}$, and 27 percent imported dissolved organic nitrogen (DON). The amount of $\mathrm{NH}_{4}$ exchanged tended to be higher than the amount of $\mathrm{NO}_{3}$. The amount of DON imported and exported was larger than that of $\mathrm{NH}_{4}$ and $\mathrm{NO}_{3}$, but the fractions but were highly variable. Younger marshes (formed in the more recent geologic past) lying closer to the upland boundary or including large areas of open water and few inlets and outlets generally tended to import $\mathrm{NH}_{4}$ and $\mathrm{NO}_{3}$ (although DON was often exported) (Tobias and Neubauer, 2009; Dame 1994). Older marshes have been found to usually export $\mathrm{NH}_{4}, \mathrm{NO}_{3}$, and $\mathrm{DON}$ (Tobias and Neubauer, 2009; Dame 1994). Tidal amplitude has also been studied as a controlling factor in net nutrient exchange in estuaries. At tidal amplitudes above 1.2 meters (m), marshes tended to switch from $\mathrm{NO}_{3}$ import to export (Childers, 1994). Loads of particulate organic nitrogen (import and export) were generally larger than loads of $\mathrm{NH}_{4}$ and $\mathrm{NO}_{3}$ (Tobias and Neubauer, 2009). The 
quotation below from Tobias and Neubauer (2009) summarizes their findings about nutrient exchanges in salt marshes.

Tidal exchange usually dominates the mass fluxes of nitrogen between salt marshes and adjacent ecosystems (Morris, 1991; Rozema and others, 2000). Thirty years of tidal flux studies show that marshes transform nitrogen, sometimes acting as a net importer or exporter of dissolved or particulate N. The magnitude, and in some cases the direction, of such exchanges can reverse on short timescales within a single marsh (Dankers and others, 1984; Wolaver and others, 1988; Whiting and others, 1989; Anderson and others, 1997) and it remains difficult to predict whether a particular marsh will import or export various nitrogen species at any given time.

\section{Purpose and Scope}

The goal of this report was to provide ANP resource managers with information necessary to develop strategies to minimize the effects of eutrophication in BHM estuary. The development of adaptive management strategies to address water-quality impairment in the estuary requires a comprehensive understanding of nutrient sources (including oceanic), seasonal variability, and historical trends as well as an understanding of sedimentation and ongoing sealevel rise. This report describes estimates of nutrient inputs to the estuary from tributaries, precipitation, and ocean tides, and outputs from the estuary on ocean tides. The potential effects of sea-level rise on changes in estuary volume and area of inundation were investigated by analyzing detailed bathymetry and light detection and ranging (lidar). Changes in estuary volume may influence eutrophication in the estuary by altering the amount of nutrients entering the estuary from the ocean and the residence time of nutrients in the estuary. Changes in the area of inundation will affect marsh vegetation and nutrient dynamics. By constructing complete nutrient budgets throughout the summer season, this report determined the relative importance of land in relation to ocean nutrient sources and the source-sink relationships for these nutrients. This report also examined sediment chronologies to assess potential shoaling in the estuary. This shoaling, by altering the thermal regime and water-residence time, may be related to eutrophication. Sediment chronologies in the estuary and fringing marsh were also reported to determine whether sediment accumulation rate was keeping up with sea-level rise.

\section{Description of Study Area}

The BHM estuary is in the southwestern part of Mount Desert Island, in eastern midcoast Maine (fig. 1). Much of the estuarine system lies within the ANP boundaries. The BHM watershed drains 21.78 square kilometers $\left(\mathrm{km}^{2}\right)$ and contains several perennial streams, including Heath, Lurvey, Marshall, and Adams Brooks, that were sampled during this study (fig. 2). The BHM watershed is composed of several small watersheds (fig. 3; table 1), four of which have been sampled for nutrient concentrations in recent years. Heath, Lurvey, and Marshall Brooks are part of the Northeast Temperate Trends Network (NETN) (Mitchell and others, 2006), in which the National Park Service (NPS) staff samples these brooks for nutrient concentrations and records discharge twice per year (in May and August) every other year. The largest subwatershed, Marshall Brook $\left(6.52 \mathrm{~km}^{2}\right)$, lies partially outside park boundaries and may be substantially affected by residential and commercial development and a former landfill. Adams Brook, the second largest subwatershed $\left(5.01 \mathrm{~km}^{2}\right)$, has some limited residential development but lies mostly within park boundaries (Doering and others, 1995). 
The land cover of the BHM watershed is primarily forested, and the vegetation is a complex assemblage of different forest types but is predominantly composed of the spruce-fir complex that contain some hardwood species and white pine (fig. 4). Other vegetation types within the watershed include the estuary-fringing salt marsh and wetland complexes along certain parts of tributary channels. Beaver activity has affected water levels and vegetation in some locations, including Heath and Adams Brook subwatersheds. The area of the fringing salt marsh, tidal creeks, and streams was estimated to be $3.49 \mathrm{~km}^{2}$ (fig. 5) (Doering and others, 1995).

Acadia National Park is located in the Northeastern Coastal Zone ecoregion at $44^{\circ} \mathrm{N}$. latitude, and its climate is influenced primarily by maritime conditions. Summers in this ecoregion tend to be more moist and cooler than in adjacent inland areas, whereas winters in this ecoregion tend to be somewhat warmer and experience less snowfall than inland areas (Kahl and others, 2000). Annual total precipitation is variable; for example, during a 50-year period (19441993 ) it ranged from $185 \mathrm{~cm}$ in 1983 to $98.8 \mathrm{~cm}$ in 1965 (S. Perrin, unpublished data, 1994). Over a 41-year period (1940-1980) precipitation averaged $123 \mathrm{~cm}$ and temperature averaged $8{ }^{\circ} \mathrm{C}$ annually (Patterson and others, 1983).

BHM is a typical estuarine ecosystem, having direct exchange with the ocean through Bass Harbor and receiving freshwater input through several small streams. The estuary is connected to the ocean through Bass Harbor. A road causeway and a natural bedrock sill near the marsh outlet dampen the tidal range from approximately 3 meters $(\mathrm{m})$ in the harbor to less than $1 \mathrm{~m}$ within the marsh, depending on the height of the tide. The presence of this sill creates an asymmetric tidal flux where flood tides enter the marsh for 2-3 hours and ebb tides leave for 910 hours (Doering and others, 1995). The water depth within the estuary is shallow, generally less than $0.5 \mathrm{~m}$ at low tide. The system is well flushed, with a residence time of less than 3 days (Kinney and Roman, 1998). It is likely that rising sea levels (approximately $11 \mathrm{~cm}$ from 1950 through 2006 in nearby Bar Harbor, Maine, (data accessed March 15, 2013, at http://www.tidesandcurrents.noaa.gov/sltrends)) have resulted in an increase in oceanic inputs (tidal volume and nutrients derived from oceanic sources) due to the tidal asymmetry (9-10 hour ebb tide and 2-3 hour flood tide in the early 1990s) in this estuary.

The main stem of the marsh creek meanders north for approximately $3 \mathrm{~km}$ and is fed by several brooks, and a secondary marsh creek meanders approximately $1.5 \mathrm{~km}$ in a southerly direction and is fed by Adams Brook (fig. 2). Salinities range from freshwater (near-zero salinity) at the upstream tidal ends of these two branches of the marsh creek to 32 parts per thousand near the outlet.

Signs of eutrophication in BHM estuary, the largest tidal marsh estuary on the island, were documented more than 20 years ago (Doering and others 1995). Evidence of continuing eutrophication in BHM in response to input of internal and external sources of nitrogen is noted in other studies (Kinney and Roman, 1998; Farris and Oviatt, 1999). A 1999 to 2000 study (Nielsen, 2002) corroborated the previous findings that dissolved inorganic nitrogen from freshwater sources was a substantial part of the total nitrogen load to BHM from Marshall and Heath Brooks. Organic nitrogen comprised most of the total nitrogen from the other tributaries (Lurvey, Adams, and Buttermilk Brooks) feeding the BHM estuary (Doering and others, 1995).

Vegetation within the marsh and the estuary were described by Kinney and Roman (1998). The marsh surface is dominated by short form Spartina alterniflora and other plants characteristic of saline to brackish-water systems. In the estuary, Ruppia maritima, a few patches of Zostera marina, and green macroalgae species, principally Enteromorpha prolifera and 
Enteromorpha flexuosa, all co-occur. E. intestinalis, Rhizoclonium riparium, as well as the yellow-green alga Vaucheria sp. and the blue-green Microcoleus lyngbyaceus are also found.

Unquantified visual observations made by the authors of this report from kayaks in the estuary several times during the course of summers in 2011 and 2012 suggest that 1) annual blooms of green macroalgae species, principally Enteromorpha prolifera and Enteromorpha flexuosa appear in spring and summer, and 2) the abundance of Ruppia maritima may have declined substantially since the report published by Kinney and Roman (1998).

\section{Methods of Measurement, Sampling, and Laboratory Analysis}

The following section describes the methods of estimation runoff from the watershed to the estuary from tributaries and the ungaged areas and methods for measuring bidirectional flow at the estuary outlet. This section also describes the measurements of water quality using in-place continuously recording sensors and the ancillary data that was compiled for this project. This section describes the methods of water quality sampling and laboratory analytical methods.

\section{Estimation of Runoff from the Watershed to the Estuary}

To estimate freshwater inputs to the BHM estuary, first, discharge was estimated from the tributaries (Heath, Lurvey, and Marshall Brooks). Periodic stream-discharge measurements were recorded during May through October on these tributaries at the locations where samples were collected for nutrient chemistry from 2006 through 2012. These discharge measurements were made by NPS staff as part of the NETN program (Mitchell and others, 2006). NPS staff were trained by USGS hydrologists and employed USGS methods for making discharge measurements. The measurement stations on these tributaries constitute partial record sites. The Move 1. regression technique (Hirsch, 1982) was used to estimate continuous discharge during May through September in 2011 and 2012 at these partial record sites. An application of this regression technique to other small tributaries on Mount Desert Island is described by Nielsen (2002). The Move. 1 regression technique is based on the relation between continuous discharge measured at an index site and discrete discharge measurements made at the partial records sites. The continuous-discharge data recorded at Otter Creek (USGS streamgaging station 01022840) that began in April of 2006 were used for the index site in this Move. 1 regression. Three measurements, out of a total of 56 on all three tributaries, were censored before the regression was performed because these points were clearly outliers that departed greatly from otherwise linear relationships. The coefficients of determination (r-squares) for the correlations between paired discharge measurements at the tributaries and at Otter Creek were 0.82 for Heath Brook, 0.87 for Lurvey Brook, and 0.93 for Marshall Brook. Discharge from Marshall Brook was used to estimate discharge for Adams Brook with a simple area adjustment (discharge at Adams Brook $=0.812 \times$ discharge at Marshall Brook). Marshall Brook discharge was used to estimate Adams Brook discharge because Adams Brook was more similar to Marshall Brook in its size than to the other tributaries and because a higher $r$-square was attained for the correlation between Marshall Brook and Otter Creek than for the other tributaries and Otter Creek.

\section{Measurement of Discharge at the Estuary Outlet}

Discharge at the estuary outlet at the Route 102 Bridge in Tremont, Maine, was measured using the index velocity method (Levesque and Oberg, 2012). In this method velocity and area are separated into two ratings - the index velocity rating and the stage-area rating. The outputs 
from each of these ratings, mean channel velocity (V) and cross-sectional area (A), are then multiplied together to compute a discharge. In the index velocity method, $\mathrm{V}$ is a function of such parameters as stream velocity, stage, cross-stream velocity, and velocity head, and A is a function of stage and cross-section shape. The index velocity method is appropriate when more than one specific discharge can be measured for a specific stage, as is inherent in a tidally reversing system such as the BHM estuary outlet. This site was especially challenging because of the asymmetric tidal phasing and high velocities during the flood tide.

For BHM a SonTek Argonaut-SW uplooker was selected for measurement of continuous velocity. The index velocity rating was developed from a series of periodic discharge measurements, taken throughout the measurement season and covering more than 90 percent of the observed velocities, with an independent acoustic Doppler current profiler (ADCP) following standard USGS procedures (Turnipseed and Sauer, 2010). The stage-area rating was developed by surveying a streambed cross section and relating the area to contemporaneous stage measurements. Data from discharge measurements and uplooker and stage sensors were compiled for index-rating analysis. Index ratings were developed by regression techniques in which the mean cross-sectional velocity for the standard section was related to the measured index velocity. Data were recorded on a 5-minute interval.

There were a few short periods when instrumentation or data transmission failed and no discharge data could be calculated. The longest period was from August 23, 2011, 18:05 to August 25, 2011, 11:50, a period in which several samples were collected from flood and ebb tides. In order to estimate discharge during this period so that these samples could be used in the LOADEST regression program (Runkel and others, 2004) and so that hourly load during this period could be estimated, the following procedure was used. Data from July 2011 during the period (neap tides) of the tidal cycle, when tidal amplitudes were nearly identical to those of the August 23-25 period of missing record, were chosen to calculate an estimate of the discharge during this period. The data were aligned such that the data for July 23, 2011, at 17:35 were compared with the data beginning on August 21, 2011, at 16:50 and continuing until August 27, 2011, at 8:20. This period was chosen because, on visual inspection, the hydrographs lined up very well in terms of the beginning and end of flood and ebb tides (all inflection points in the hydrograph were matched to within 30 minutes or less during this period), and the absolute levels of discharge were closely aligned. The biggest differences were observed during the periods of highest discharge in midflood. The largest percentage differences were observed during the lowest discharges.

To assess the error associated with this method of estimation, the estimated discharge value was compared with the measured value for the periods of overlapping record (August 21, 2011 16:50 to August 23, 2011 18:05 and August 25, 2011 11:50 to August 27, 2011 8:20). During these periods of overlapping data, the median error was 11 percent, and the median difference in discharge was 7.9 cubic feet per second $\left(\mathrm{ft}^{3} / \mathrm{s}\right)$; 90 percent of the time the absolute error was less than 35 percent, and the absolute difference was less than $39 \mathrm{ft}^{3} / \mathrm{s}$.

\section{Continuous Water-Quality Measurement and Ancillary Data}

Continuous temperature, specific conductance, and turbidity data were collected at a 5minute time interval using a YSI model 600 OMS V2 sonde. The sonde was deployed at the estuary outlet (fig. 2) 1.2 meters upstream and 1.2 meters east (into the channel) from the western Route 102 bridge abutment at a depth of $20 \mathrm{~cm}$ above the bedrock sill. The sonde remained submerged at a depth of at least $15 \mathrm{~cm}$ even under the lowest water-level tidal 
conditions. The sonde was equipped with a YSI model 6136 optical turbidity sensor. A handheld YSI model 6600 sonde equipped with the same sensors was used for calibration and validation of the in-place continuously monitoring sonde and was also used to obtain specific conductance, temperature, and turbidity through the cross section at the outlet where the continuously monitoring sonde was deployed. To ensure data quality, the sondes were calibrated and tested following standard manufacturer and USGS (Wagner and others, 2006) procedures prior to, during, and after deployment.

Daily precipitation data were obtained from the National Park Service (NPS at ANP). The NPS maintains a National Atmospheric Deposition Program (NADP) monitoring site that uses a tipping bucket rain gage to record daily precipitation data at McFarland Hill on Mount Desert Island. The McFarland Hill site is about $13 \mathrm{~km}$ generally northeast of the centroid of the BHM Watershed. The NADP program is administered by the Illinois State Water Survey, Champaign, Ill. (National Atmospheric Deposition Program, 2012).

Tidal data were obtained from National Oceanic and Atmospheric Administration (NOAA) data files (2012) for Frenchman's Bay, Bar Harbor, Maine on Mount Desert Island. Stream-water discharge records were obtained for Otter Creek near Bar Harbor, Maine (USGS streamgaging station 01022840) from the USGS National Water Information System (NWIS) (2013b).

\section{Water-Quality Sampling}

Samples were collected for nutrient analysis (table 2) from Marshall, Heath, Lurvey, and Adams Brooks, and from the estuary outlet (fig. 2). Grab samples were collected from tributaries approximately once monthly from June through October in 2011 and 2012. Samples were collected from the estuary outlet every 2 to 4 weeks during successive flood and ebb tides from June through October in 2011 and 2012. Usually 2 or 3 samples were collected on flood tides and 2 to 5 samples were collected on ebb tides. Samples were collected during spring and neap tides. In 2011 most samples were collected using an automated sampler programmed to collect a sample every hour. The automated-sampler intake line was located approximately $25 \mathrm{~cm}$ above the bedrock sill and about 1.7 meters streamward from the western bridge abutment. On a few occasions in 2011 grab samples were collected at this location.

Preliminary analyses of water temperature and specific conductance made through the cross section at the estuary outlet during 2011 showed that the water was well mixed during flood tides but that during ebb tides the water was not well mixed vertically. A vertical gradient was observed such that the surface layer was lower in salinity, and the gradient was more pronounced when there was more runoff from the watershed into the estuary than during periods of low runoff. During periods of low runoff in late summer, a substantially smaller vertical gradient was observed during ebb tides, so that there was usually less than 10 to 15 percent variation in specific conductance in a vertical profile. Analyses of specific conductance, temperature, and turbidity made with a hand-held sonde confirmed these earlier preliminary observations (figs. 6 and 7). Because of the vertical variation in specific conductance during ebb tides during periods of higher runoff, in 2012 all samples were collected, with a hand-held US DH-81 isokinetic depth-integrating sampler equipped with a 0.79 -cm-diameter nozzle, across the section where the point samples had been collected in 2011. The US DH-81 sampler configuration is designed for flow velocities between 0.55 and 2.1 meters per second $(\mathrm{m} / \mathrm{s})$ to insure isokinetic sampling (Lane and others, 2003). Sampling during the ebb tide was conducted during flow velocities within this range. During flood tides, flow velocities were frequently 
greater than $2.1 \mathrm{~m} / \mathrm{s}$, and at those times isokinetic sampling was not attained, but we are confident that we collected representative samples during the flood tide because conditions during flood tides indicated that that the water was well mixed throughout the cross section at the estuary outlet. The DH-81 sampler was used to obtain a sample that was representative of all the water flowing into or out of the estuary through the cross section. In 2012, 9 point samples (4 flood tide and $5 \mathrm{ebb}$ tide) were collected at the location of the automated-sampler intake during 2011 to compare the nutrient concentrations of the point sample to those collected with the isokinetic depth-integrating sampler.

As expected, the average percent differences (absolute values) between integrated and point samples were generally smaller on the flood tide than on the ebb tide, except for TDN where there were larger differences on the flood tide. Positive and negative differences between integrated and point samples were observed on flood and ebb tides. Average differences on the flood tide were $-3.7,13,-18$ and 5.2 percent for $\mathrm{NH}_{4}, \mathrm{NO}_{3}$, TDN and total dissolved phosphorus (TDP), respectively, and average differences on the ebb tide were $-25,1.5,14$, and 13 percent for $\mathrm{NH}_{4}, \mathrm{NO}_{3}$, TDN and TDP, respectively. Analysis of field-replicate samples showed absolute differences between 3.1 and 67 percent (mean $=27$ percent), depending on the constituent. In the laboratory, differences between duplicate analyses were usually less than 5 percent, indicating that the largest source of variation occurred during field sampling. The source of this variation is likely a combination of systematic variation within the cross section, impossibility of sampling in the exact same location, and temporal variation inherent in this system. There are insufficient data to justify any adjustment of the 2011 point sampling because the limited data do not show a systematic difference between integrated and point sampling. There is a substantial amount of error in individual nutrient concentration measurements and consequently in the resulting load calculations, but there is no evidence of a systematic bias.

Samples were collected in prewashed and acid-rinsed polyethylene bottles. Samples were filtered within 24 hours of collection through a cartridge filter $(0.45$-micrometer $(\mu \mathrm{m})$ polyethersulfone membrane) and into a $125-\mathrm{mL}$ amber polyethylene bottle at each measuring site. Samples were maintained chilled (approximately $4{ }^{\circ} \mathrm{C}$ ) following collection until they were returned to the USGS Maine Office of the New England Water Science Center in Augusta, Maine. At the USGS Maine Office the samples were frozen until shipment to the University of Maryland, Analytical Services Laboratory, in Horn Point, Md.

\section{Laboratory Analytical Methods}

Ammonia $\left(\mathrm{NH}_{3}\right)$ was analyzed colorimetrically by the automated phenate method [EPA350.1] (U.S. Environmental Protection Agency 1979a; O’Dell, 1993; American Public Health Association, 1998, method 4500-NH3-F, p. 4.108-4.109). In this report all $\mathrm{NH}_{3}$ plus $\mathrm{NH}_{4}$ is reported as $\mathrm{NH}_{4}$ because at the $\mathrm{pH}$ of the tributaries to the estuary the ratio of $\mathrm{NH}_{4}$ to $\mathrm{NH}_{3}$ was estimated to be from 100 to greater than 1,000 based on the dissociation constant for $\mathrm{NH}_{4}$ (at $25^{\circ} \mathrm{C}, \mathrm{Ka}=5.89 \times 10^{-10}$ ) (Culbertson and others, 2007; NETN data from - William Gawley, [National Park Service], written commun., February 25, 2013), and in the estuary this ratio was estimated to be 10 to 100 (Culbertson and others, 2007). At the $\mathrm{pH}$ of seawater in the GOM (8.1 at $25^{\circ} \mathrm{C}$ ) $\mathrm{GOM}$ the ratio of $\mathrm{NH}_{4}$ to $\mathrm{NH}_{3}$ would be 13.5. Total dissolved phosphorous was analyzed as phosphate colorimetrically by the automated, molybdate method [EPA 365.1], following alkaline persulfate digestion (U.S. Environmental Protection Agency 1979c; Valderrama, 1981). Nitrate plus $\mathrm{NO}_{2}$ were analyzed colorimetrically by the automated cadmium reduction method [EPA 353.2] (U.S. Environmental Protection Agency 1979b; Wood and others 
1967; American Public Health Association, 1998, method 4500-NO3-F, p. 4.118-4.119). The concentration of $\mathrm{NO}_{2}$ in these waters is expected to be below the laboratory detection limit based on a previous study at ANP (Culbertson and others, 2007); therefore, throughout this report, this analysis $\left(\mathrm{NO}_{3}\right.$ plus $\left.\mathrm{NO}_{2}\right)$ is referred to as $\mathrm{NO}_{3}$. Total dissolved nitrogen was analyzed colorimetrically by the automated cadmium reduction method [EPA 353.2] following alkaline persulfate digestion (U.S. Environmental Protection Agency 1979b; Valderrama, 1981).

\section{Methods of Modeling Nutrient Loads with LOADEST}

The USGS Load Estimator (LOADEST) regression model (Runkel and others, 2004) was used to model (calculate) nutrient loads from the tributaries to BHM estuary. The LOADEST regression model was also used to calculate nutrient loads across the ocean-estuary boundary at the Route 102 bridge in Tremont, Maine.

\section{Modeling Nutrient Loads from Tributaries}

The USGS Load Estimator (LOADEST) regression model (Runkel and others, 2004) was used to calculate hourly nutrient loads from Heath, Lurvey, and Marshall Brooks. The LOADEST approach uses discrete pairs of concentration and discharge data to calibrate the adjusted maximum likelihood estimate (AMLE) regression between constituent load, streamflow, and seasonality. The instantaneous discharge associated with each sample was determined from the MOVE.1 regression and discharge data from nearby Otter Creek, described above, because discharge measurements were not made when these samples were collected. The MOVE.1-calculated continuous hourly discharge data were then used to compute hourly nutrient loads using the AMLE results from LOADEST. The model "centers" explanatory variables (time and streamflow) to eliminate colinearity and automatically selects one of nine predefined regression models to fit the data. The selected regression models are shown in table A1.

Analysis of residuals to these AMLE regression models indicated that relationships between the log of nutrient load and the log of streamflow were generally linear, and there was random distribution of observations around the regression line. Inspection of plots of the log of nutrient load in relation to model residuals further indicated that the model residuals were independent and homoscedastic (having constant variance). These analyses of residuals supported the assumptions of the regression model (Runkel and others, 2004). Regression model bias was evaluated using the LOADEST software-derived statistics: the load bias in percent and the Nash Sutcliffe efficiency index $(E)$. A positive load bias indicates an overestimation and a negative load bias indicates an underestimation. A small overestimate was observed in all cases except for TDN on the ebb tide, where a small underestimate was observed (table A2). In all cases the load bias percent was less than 25 percent, indicating that the regression model is appropriate. Values of $\mathrm{E}$ range from negative infinity to 1.0 , with a value of 1.0 indicating a perfect fit and a value of 0.0 indicating that the load estimates are only as accurate as the mean. Values of $\mathrm{E}<0$ indicate that the observed mean is a better estimate of load than the selected regression model. The $\mathrm{E}$ values for the regression models for all nutrients on flood and ebb tides were greater than zero (table A2), indicating that the regression models were justified and superior to simple load calculations based on the product of mean concentration and discharge volume.

Analysis of uncertainty in AMLE regression models can be expressed as the 95-percent confidence intervals of the standard error of prediction for the estimation period in kilograms per 
day (kg/day), and these limits are generated directly from LOADEST. There was substantial variability in the magnitude of the confidence intervals relative to the mean load estimates, depending on the tributary and nutrient. The lower confidence intervals were usually within the range of 30 to 50 percent of the mean value, and the upper confidence intervals were usually within the range of 45 to 75 percent of the mean value (table A3). The uncertainty was usually highest for $\mathrm{NO}_{3}$ and lowest for TDN and TDP. There is substantial uncertainty in these load estimates in part because of natural variability in these tributaries. Uncertainty also arises from errors in discharge measurement at Otter Creek, Move.1 regressions, area adjustments for estimation of discharge, and error inherent in laboratory nutrient analysis. Quantitative estimation of the combined error is beyond the scope of this report. Given the large uncertainties associated with these load calculations, care should be taken in use of specific quantitative estimates.

Adams Brook was treated separately because there were insufficient samples from Adams Brook to run LOADEST, since LOADEST requires a minimum of twelve samples. Adams and Marshall Brooks are of similar size and were sampled on the same dates, but substantial differences in nutrient concentrations were observed between the two tributaries. The median ratios of nutrient concentrations (concentration in Adams Brook divided by concentration in Marshall Brook) were calculated for the eight samples collected on the same dates. The coefficients of variation for these nutrient ratios generally ranged from 0.39 to 0.58 . These ratios were then multiplied by the measured concentrations at Marshall Brook for all of the sampling dates at Marshall, and these ratios were assumed to be reasonable estimates of the nutrient concentrations at Adams on these dates. Instantaneous and average hourly discharge at Adams Brook were obtained using a simple area adjustment applied to the discharge at Marshall Brook.

These estimated nutrient concentration and discharge data for Adams Brook made it possible to run the LOADEST model for this tributary in a way that would be more accurate than a simple area adjustment from the area-weighted mean loads from the three measured tributaries. Adams Brook contains a relatively large wetland that probably results in substantially different nutrient concentrations than the other tributaries: specifically, higher dissolved organic nitrogen, $\mathrm{NH}_{4}$, and TDP, and lower $\mathrm{NO}_{3}$. We calculated nutrient loads from the ungaged watershed area from the area-weighted average loads from Heath, Lurvey, and Marshall Brooks.

\section{Modeling Nutrient Loads Across the Ocean-Estuary Boundary}

The LOADEST regression model (Runkel and others, 2004) was also used to estimate hourly nutrient loads across the ocean-estuary boundary. Continuous discharge data were recorded on a 5-minute interval on both ebb tides (coded positive) and flood tides (coded negative) at the index velocity gage at the estuary outlet. Paired nutrient concentration and associated instantaneous discharge data collected in 2011 and 2012 were used to calibrate the LOADEST model. Separate models were obtained for each nutrient and for ebb and flood tides. In most cases the "best-fit" model automatically chosen by the LOADEST regression program indicated seasonal variation in concentration for equivalent discharges (table A1).

The continuous discharge data were aggregated from 5-minute to hourly average data because the hourly time step is the smallest time step that LOADEST will run. At the beginning and end of each ebb and flood tide, where part of each hour was ebb and part flood, the hour was assigned both a flood and an ebb hourly average discharge based on the period of flow that occurred during flood or ebb. LOADEST was not designed to compute loads bi-directionally, 
and it could not run with a zero value for hourly average discharge. Therefore, separate models of LOADEST were run for flood and ebb as though the water were flowing continuously in the flood or the ebb direction, respectively. For hours where flood or ebb flow was actually zero, a value of $1.0 \mathrm{ft}^{3} / \mathrm{s}$ was used and the resulting load was set to zero after the regression was completed.

Analysis of AMLE regression models residuals for tidal loads indicated that: (1) relationships between log of load and log of streamflow were linear; (2) in general, assumptions of normality were supported; and, (3) plots of log of loads in relation to model residuals yielded no clear patterns or trends. There was substantial variability in the magnitude of the confidence intervals relative to the mean load estimates depending on the tidal load (floor or ebb) and nutrient considered. The lower confidence intervals were usually within the range of 6 to 30 percent of the mean value, and the upper confidence intervals were usually within the range of 7 to 40 percent of the mean value (table A1). The uncertainty was usually lowest for ebb tidal loads and highest for flood tidal loads.

There is substantial uncertainty in these tidal-load estimates, although the uncertainty is less than that observed for the tributary loads. Uncertainty arises from errors in discharge measurement, errors associated with obtaining a representative water sample at the estuary outlet that is not well mixed due to salinity stratification and turbulence, and errors inherent in laboratory nutrient analysis. Quantitative estimation of the combined error is beyond the scope of this report. Given the large uncertainties associated with these tidal-load estimates, care should be taken in use of specific quantitative estimates.

The hourly loads were aggregated to compute tidal loads for each complete flood and ebb tide so that water and nutrient inputs could be compared between flood and following ebb tides at various time scales from individual tidal cycles to the complete summer measurement seasons. Hourly tributary inputs during tidal cycles were also computed to calculate nutrient budgets for the estuary during each flood-followed-by-ebb tidal cycle to determine the importance of watershed-derived nutrients in relation to ocean-derived nutrients and to obtain an estimate of the residual to the measured nutrient inputs to the estuary and outputs (export) from the estuary. The mass balance equation that describes these components is:

(flood tide inputs + tributary inputs + precipitation inputs) - ebb tide outputs (export) $=$ residual

The residual is assumed to be net retention within the estuary (if positive) or net release (export) from the estuary (if negative). The residual may include some combination of uptake by macroalgae, mineralization, un-quantified groundwater inputs and measurement error.

\section{Method of Mapping Current and Historical Estuarine Conditions}

\section{Development of Estuary Bathymetry}

Bathymetric data were collected on July 5, 2012, from 10:56 to 14:55, a period that straddled the highest water elevation in the estuary during the flood and early ebb tide. Water depth and location data were recorded continuously on a one second interval. The data were collected using a time-synchronized Teledyne RD Instrument's RiverRay Acoustic Doppler Current Profiler (ADCP) coupled with a high precision global positioning system (GPS). The RiverRay ADCP is mounted on a miniature trimaran that was towed behind a kayak. The kayak went back and forth across the estuary from the mouth of the estuary to the upper reaches until 
the estuary became too narrow to navigate (fig. 8). The ADCP and GPS were used to collect highly dense and precisely located depth data in a relatively short period of time. ADCP data were logged in Teledyne RD Instrument's WinRiver II software with time and synchronized to the string of GPS data. The GPS location was referenced to a reference point (RM3) established near the outlet. The vertical datum of RM3 is 2.121 North American Vertical Datum of 1988 (NAVD 88). The objective was to determine the bathymetry and water volume at a single point in time at the maximum water level during the tidal cycle on July 5, 2012, at 14:01. At this date and time the water level at RM3 was $1.357 \mathrm{~m}$ NAVD 88.

The depths determined by the ADCP were validated by comparing several depth measurements with depths recorded manually with a survey rod to the nearest hundredth of a foot while the ADCP was held stationary. The bottom sediments were relatively firm and well defined, resulting in rod measurements that were reproducible. Four rod measurements were made during the survey on July 5, 2012, between 12:36 and 13:27 at depths ranging from 31.09 to $48.16 \mathrm{~cm}$ (rod depth). ADCP data were averaged for one minute centered on the time recorded for the rod measurement. The mean difference between the rod-and ADCP-depth data was $1.22 \mathrm{~cm}(0.427-\mathrm{cm}$ standard deviation).

The coupled ADCP and WinRiver II software reported the latitude, longitude, and average depth of the four beams. Water level within the estuary was monitored continuously with pressure transducers at three locations during the bathymetric measurements. The time on the pressure transducers was synchronized with the ADCP and GPS. The locations of the pressure transducers were immediately upstream from the estuary outlet and at 310.9 (TBM101) and 592.2 (TBM102) m upstream near the eastern shore of the estuary, where latitudes, longitudes, and elevations were determined using standard surveying techniques. The water levels at these locations were recorded in order to adjust the ADCP-determined water depths to a uniform time (what they would have been at 14:01). The depths were all adjusted to correspond to the maximum water depth as recorded at the pressure transducer immediately upstream of the estuary outlet (RM3) at 14:01. These adjustments were necessary because (1) the water level fluctuates continuously within the estuary and (2) there is a slight slope in the surface of the water whose sign and magnitude varies with time during the ebb and flood tides (fig. 9). The adjustments were based on the water level at RM3 and the slope of the water surface extrapolated to the distance away from RM3 in time and space.

The resulting bottom-elevation data files were processed in ArcMap 10.1 (ArcGIS Software, Environmental Systems Research Institute, ESRI) for bathymetric mapping. Standard computational steps were used to convert the data into the horizontal (North American Datum of 1983) and vertical (NAVD 88) datums and linear units (meters) of the base topographic dataset, which was a high-precision digital elevation model derived by light detection and ranging (lidar) methods, for coastal Maine.

Standard tools in ArcMap 10.1 were used to create raster-interpolated surfaces from the point elevations. The mathematical algorithms in these tools include Inverse Distance Weighting (IDW), Kriging, and Natural Neighbor. Each raster was clipped to the estuary shoreline using a shoreline polygon which was created from the lidar. IDW and Kriging tools have parameters that set the limit of the search radius to minimize the influence of points at greater distances. Because the largest physical distance between transects was 102 meters, the search radius was set to a maximum of 105 meters. This resulted in uniform surfaces having no holes or gaps. After evaluating the IDW, Kriging, and Natural Neighbor algorithms, Natural Neighbor was chosen as 
the most appropriate for this analysis. The cell size of $2 \mathrm{~m}$ produced good resolution for all interpolated surfaces.

\section{Estimating Effects of Sea-Level Rise on Area of Inundation in Bass Harbor Marsh}

To estimate the effect of 50,100, and $200 \mathrm{~cm}$ of sea-level rise (SLR) on the inundated area within BHM, lidar-derived elevation data were used following the method of Gesch and others (2009). Future rates of SLR are unknown, but the rates used cover the full range of projections for potential SLR by the end of the 21 st century that are included in the technical input to the National Climate Assessment (Parris and others, 2012). To evaluate the effects of these SLR scenarios, maps were constructed of predicted inundated areas within BHM. The area and water volume of the estuary at mean higher high water (MHHW) and mean lower low water (MLLW) in the current condition was compared with the changes in area and volume associated with SLR of 50, 100, and $200 \mathrm{~cm}$. MHHW and MLLW were calculated from the continuously recorded 5-minute gage-height data at the estuary outlet during 2011 and 2012. MHHW was estimated as the average of the highest recorded water level each day from the data. MLLW was estimated as the average of the lowest recorded water level each day from the data. The water levels used in the calculations were $1.226 \mathrm{~m}$ for MHHW and $0.727 \mathrm{~m}$ for MLLW. To estimate the increase in water level in the estuary that would result from the SLR scenarios of 50, 100, and $200 \mathrm{~cm}$, maximum water levels in the ocean and corresponding maximum levels in the estuary were compared during neap and spring tides. The increase in water level between neap and spring tides in the ocean was about $74 \mathrm{~cm}$ and the corresponding increase in water level in the estuary was about $45 \mathrm{~cm}$. Therefore, it was assumed that the water level in the estuary would increase by about 60 percent of that observed in the ocean because of the flow restriction at the outlet. The effective increases in MHHW and MLLW in the estuary associated with the SLR scenarios of 50,100, and $200 \mathrm{~cm}$ were then 30,60 , and $120 \mathrm{~cm}$.

Contours were created from lidar data using a model builder tool constructed for a previous USGS study on the effects of sea-level rise on salt marshes (Nielsen and Dudley, 2013). That study determined the lidar accuracy to be within $26 \mathrm{~cm}$ of high-accuracy GPS survey points within the BHM area. For this reason, sea-level rise contours were constructed in such a way as to have upper and lower confidence contours of $26 \mathrm{~cm}$. The high marsh elevations were determined by constructing polygons of the salt-marsh area using high resolution aerial photographs provided by Bing map online resource (Bing, 2010). Lidar data were used to assign elevations to the edges of the salt-marsh polygons where the salt marsh ends and forest or other vegetation begins. These salt-marsh polygons attributed with high marsh elevations were obtained from the USGS Acadia salt-marsh study database (Nielsen and Dudley, 2013). The high marsh-elevation contours were used to determine the difference in present high-tide inundation and future sea-level-rise conditions.

Three separate polygon layers for BHM were created and attributed with the same high marsh elevations for the marsh polygons, sea-level-rise-estimate elevation, and the upper and lower confidence elevations. The field calculator was used to add $26 \mathrm{~cm}$ to the sea-level-rise estimate for the upper confidence and subtract $26 \mathrm{~cm}$ for the lower confidence. These $26-\mathrm{cm}$ confidence polygons were created for the $50-\mathrm{cm}, 100-\mathrm{cm}$, and $200-\mathrm{cm}$ polygon layers. These polygons and the lidar data were used as input features for the model builder tool to construct the sea-level-rise contours.

Most of the high marsh elevations were found to be at slightly different elevations from each other. For this reason some contours were slightly offset from neighboring polygons and 
had to be matched up by manually editing each line and merging all lines together. To construct inundation polygons, each set of contours was closed off. The 50-cm contours were closed off at the outlet of the estuary. The $100-\mathrm{cm}$ and $200-\mathrm{cm}$ contours were closed off along the major road at the outlet, under the assumption that that the road would be a physical barrier to sea-level rise and would be built up in the future to restrict inundation. After construction of the polygons representing different inundated areas associated with 50-, 100- and 200-cm of sea-level rise, these polygons were merged with the bathymetry and lidar-elevation data to compute the volume of water in the estuary during these high-tide conditions at each SLR scenario.

\section{Estimating Channel Widening within Bass Harbor Marsh}

Anecdotal reports of shoaling within the estuary in recent decades led to the hypothesis that erosion and collapse of channel banks could be the source of sediment responsible for shoaling. Historical aerial photographs of the BHM estuary were provided the National Park Service. These photographs were studied to determine whether they would show evidence for changes in channel width within the BHM estuary. The aerial photographs were from 1944, 1955, 1964, 1979, and 1997. The aerial photographs from 1944 and 1979 were georeferenced images, but photographs from 1955, 1964, and 1979 were not georeferenced. The 1944 and 1979 images were checked for quality using the Bing map (Bing, 2010) as a reference; both matched up well with only slight variations (less than a meter) in some areas. These variations could be attributed to roadway changes and other newly developed areas as well as georeferencing inaccuracies. The 1955, 1964, and 1997 aerial photographs were georeferenced using ArcMap 10.1. Digital control points were established on features that were discernible on all the images and on the Bing map base layer, (Bing, 2010) and the resultant georeferenced images were inspected for consistency and accuracy.

A geodatabase was created for delineation of the Bass Harbor estuary channel. Six polygon datasets were created to represent the extents of the estuary channel and the marsh estuary in the years 1944, 1955, 1964, 1979, 1997, and 2010. The resolution of the historical images made it difficult to estimate the normal channel conditions for the estuary. However, each historical image provided a contrast boundary along the channel banks of the estuary that indicated the presence of a high-tide mark or change in vegetation. In order to implement a consistent delineation method, the channel in each historical image was delineated along the midsection between the darkly colored water surface and the contrast boundary along the channel banks. This consistent approach minimized any biases for channel widening over the years.

The estuary boundary on each historical image was delineated from the outlet of the estuary and the inlet of Adam's Brook to the northernmost extent of the marsh. Each boundary was clipped at the same downstream section to create polygons that had consistent downstream extents, and the area of each estuary-boundary polygon was calculated.

In a similar manner, the marsh area for each year was delineated to determine whether channel widening caused proportional decreases in marsh area. A previously delineated polygon of BHM (Nielsen and Dudley, 2013) was used to represent the 2010 year. Nielsen and Dudley (2013) used lidar-derived digital elevation models, land-surveyed control points, and digital color aerial photographs taken during low-tide conditions in 2008 to define the boundary between uplands and the marsh. It was assumed that the upland marsh boundary defined by Nielsen and Dudley (2013) remained constant from the date of the earliest aerial image (1944) until the present and reflected the elevation of mean higher high water that is sometimes used as 
an alternative to this boundary. Vegetation is a more accurate indicator of marsh elevation than a specific tidal elevation in these environments (M. Nielsen, Hydrologist, oral communication). This marsh area polygon was edited to match the 2010 Bing basemap (Bing, 2010) as accurately as possible. The inland marsh perimeter was not changed for any of the years to keep a control on polygon area. The northern and southern extents of the polygons were unchanged as well for further control on area. The marsh surface area was determined as the area of the polygons formed from the boundaries between the estuary and the marsh on the one hand and the marsh and the upland on the other.

\section{Methods of Sediment Coring and Analysis for Determination of Mass and Sediment Accumulation Rates}

Four sediment cores were collected on September 1 and 2, 2009, manually from a small boat with a push corer from various locations in the estuary (table 3, fig. 5). Recovered cores were 40 to $50 \mathrm{~cm}$ in length. Vertical sediment core samples were sectioned by upward extrusion at 2-cm intervals to $10 \mathrm{~cm}$, and at 3-cm intervals thereafter. Samples were shipped on ice to the USGS Menlo Park Sediment Radioisotope Lab for radioisotope analysis to determine sediment accumulation rates. Sediments were freeze-dried to allow powdering to facilitate packing into counting vials to obtain constant geometry among samples. Splits of sediments were taken in the field to determine water content and bulk density. These samples were sealed in glass vials and upon return to the lab were weighed wet and after drying at $110{ }^{\circ} \mathrm{C}$ to constant weight. Sediment bulk density (grams dry sediment per cubic centimeter) was assumed to equal $2.6 \mathrm{~g} / \mathrm{cm}^{3}$. Organic matter content was determined by gravimetric loss on ignition (LOI) at $500{ }^{\circ} \mathrm{C}$ for 24 hours (Davies, 1974), a measure of the total organic matter content of the sediment. All organic matter content results are presented on an oven-dry weight $\left(105^{\circ} \mathrm{C}\right.$ constant weight) basis.

Five marsh surface cores were collected November 2 and 3, 2011, using a Hargis corer, a razor-edged, 15-cm-diameter piston corer that minimizes soil compaction (Hargis and Twilley, 1994). Four sites were sampled: two on the west side of the estuary (BHM.S2 and BHM.S3) and two on the east side (BHM.S1 and BHM.S4) with replicate cores collected at site 4 (BHM.S4a and BHM.S4b) (table 3, fig. 5). Core recoveries ranged from 32 to $46 \mathrm{~cm}$. Cores were stored upright and sectioned within two days of recovery by upward extrusion and slicing at vertical 2-cm intervals. Minimal compression of material was observed during the sectioning process. A subsection of each interval was sampled at the time of slicing for water content and loss on ignition. After drying to determine water content, the subsection samples were combusted at $500{ }^{\circ} \mathrm{C}$ for 24 hours to determine LOI. The remaining sample was transported on ice to the USGS Menlo Park lab. Samples were freeze-dried, then homogenized, and subsampled for environmental radioisotope analysis.

Sediment accumulation rates were determined using ${ }^{210} \mathrm{~Pb}$ sediment dating methods (Appleby and Oldfield, 1992; Van Metre and others, 2004). ${ }^{210} \mathrm{~Pb}$ dating methods are based on the decay ${ }^{210} \mathrm{~Pb}$ (half-life 22.3 years) over time to its background or supported activity defined by the activity of ${ }^{226} \mathrm{Ra}$, its long-lived progenitor (half-life 1600 years). ${ }^{210} \mathrm{~Pb}$ activities greater than the ${ }^{226} \mathrm{Ra}$ activity are termed unsupported or excess ${ }^{210} \mathrm{~Pb}$. Unsupported ${ }^{210} \mathrm{~Pb}$ in sediments results from the emanation of ${ }^{222} \mathrm{Rn}$ gas from continental land masses to the atmosphere. ${ }^{222} \mathrm{Rn}(3.8$ day half-life) is an intermediate in the ${ }^{238} \mathrm{U}$ decay series between ${ }^{226} \mathrm{Ra}$ and ${ }^{210} \mathrm{~Pb}$. Decay of ${ }^{222} \mathrm{Rn}$ decays in the atmosphere to produce ${ }^{210} \mathrm{~Pb}$, which is subsequently deposited onto the estuary surface and watershed and scavenged by sediment particles that are then deposited onto the 
sediment surface. This process results in unsupported ${ }^{210} \mathrm{~Pb}$ in recently deposited sediment. Following sediment deposition, the unsupported ${ }^{210} \mathrm{~Pb}$ decays over time until only the supported activity defined by the ${ }^{226} \mathrm{Ra}$ activity remains. At that time, ${ }^{210} \mathrm{~Pb}$ decays at the same rate it is produced by ${ }^{226} \mathrm{Ra}$ decay, which is termed secular equilibrium. Because the decay rate of ${ }^{210} \mathrm{~Pb}$ is defined by its half-life (22.3 years), the sediment profile of unsupported ${ }^{210} \mathrm{~Pb}$ provides a measure of sediment accumulation rate, which is calculated using well-established methods (Appleby and Oldfield, 1992; Van Metre and others, 2004). For example, the unsupported ${ }^{210} \mathrm{~Pb}$ activity decreases exponentially with depth in a system with a constant sediment accumulation rate. In this case, the exponential decrease resulting solely from the decay of unsupported ${ }^{210} \mathrm{~Pb}$. The sediment age at any depth is thus defined by the change in unsupported activity between the surface and that depth.

The anthropogenic radionuclide ${ }^{137} \mathrm{Cs}$ provides a means to test the ${ }^{210} \mathrm{~Pb}$ chronology because of its well-known input history. ${ }^{137} \mathrm{Cs}$ in estuarine sediments is derived from atmospheric fallout from aboveground nuclear weapons testing in the 1950's and first half of the 1960's. The first occurrence is commonly assigned a date of 1952, with maximum deposition occurring during the years 1963 and 1964. Atmospheric fallout decreased following this period with no measurable fallout detected after 1976 (Callender and Robbins, 1994). The profile of ${ }^{137} \mathrm{Cs}$ in an undisturbed sediment profile should reflect this temporal input history of atmospheric fallout providing time horizons to compare the chronology derived from ${ }^{210} \mathrm{~Pb}$.

Freeze-dried subsections of the estuary and marsh-surface cores were analyzed at for ${ }^{210} \mathrm{~Pb},{ }^{226} \mathrm{Ra},{ }^{137} \mathrm{Cs}$ and ${ }^{7} \mathrm{Be}$ activity to estimate sediment accumulation rates for assigning dates to core profiles. Activities of total ${ }^{210} \mathrm{~Pb},{ }^{226} \mathrm{Ra},{ }^{137} \mathrm{Cs}$, and ${ }^{7} \mathrm{Be}$ were measured simultaneously by gamma spectrometry based on previously published methods (see Van Metre and others, 2004; Fuller and others, 1999). The intervals from the top $6 \mathrm{~cm}$ of each core were analyzed for ${ }^{7} \mathrm{Be}$ (half-life 53 days) within six weeks of collection. The presence of ${ }^{7} \mathrm{Be}$ in surface sediments provides an indicator of recent sediment deposition and reworking by mixing or resuspension processes. The supported ${ }^{210} \mathrm{~Pb}$ activity, defined by its long-lived progenitor, ${ }^{226} \mathrm{Ra}$ activity, was determined on each interval from the 352-kiloelectron-volts $(\mathrm{KeV})$ and $609-\mathrm{KeV}$ gamma emission lines of ${ }^{214} \mathrm{~Pb}$ and ${ }^{214} \mathrm{Bi}$ daughters of ${ }^{226} \mathrm{Ra}$, respectively. Because the low energy 46$\mathrm{KeV}^{210} \mathrm{~Pb}$ gamma emission is absorbed in part by the sample (self-absorption), ${ }^{210} \mathrm{~Pb}$ count rates were corrected for self-absorption using an attenuation factor for each counting vial calculated from an empirical relationship between self-absorption and the sample bulk density developed for the counting geometry based on the method of Cutshall and others (1983). Self-absorption of the ${ }^{214} \mathrm{~Pb},{ }^{214} \mathrm{Bi}, 474-\mathrm{Kev}{ }^{7} \mathrm{Be}$ and the $661.5-\mathrm{KeV}{ }^{137} \mathrm{Cs}$ gamma emission lines was negligible, and, therefore, count rates for these radioisotopes were not corrected. Detector efficiency for each isotope was determined using National Institute of Standards and Technology (NIST) traceable standards. NIST and International Atomic Energy Agency reference materials were used to check detector calibration. The reported uncertainty in the measured activity calculated from the random counting error of samples and background spectra at the one-standard-deviation level was typically less than plus-or-minus 10 percent of the measured activity. The measured activities of replicate analyses of material from the same interval agreed to within plus-or-minus 15 percent. The total activities of unsupported ${ }^{210} \mathrm{~Pb}$ and ${ }^{137} \mathrm{Cs}$ were determined by multiplying the activity of each interval by the interval bulk density and the interval thickness and summing the value for each interval over the entire depth range of measurable unsupported ${ }^{210} \mathrm{~Pb}$ or ${ }^{137} \mathrm{Cs}$. The whole core total activity is termed inventory and has units of activity per area. 
Sediment mass accumulation rates (MAR) were determined using the Constant Rate of Supply ${ }^{210} \mathrm{~Pb}$ dating method (CRS) for both the estuary and marsh profiles (Appleby and Oldfield, 1992). The CRS method assumes a constant rate of input of unsupported ${ }^{210} \mathrm{~Pb}$ activity per gram and determines a sediment accumulation rate for each core interval by mass balance (in units of grams per square centimeter squared per year, g/ $\mathrm{cm}^{2} / \mathrm{yr}$ ). The Constant Flux:Constant Sedimentation method (CF:CS; Appleby and Oldfield, 1992) was also applied to the marshsurface ${ }^{210} \mathrm{~Pb}$ profiles. Based on the assumption that ${ }^{210} \mathrm{~Pb}$ is associated with inorganic sediment, the method was modified to account for loss of mass from organic matter degradation over time. The CRS method is based on the unsupported ${ }^{210} \mathrm{~Pb}$ activity per unit area in each core interval, so correction for change in organic content is accounted for in the model construct. Both methods use cumulative dry mass for the vertical axis, instead of depth, to account for compaction.

The resulting sediment accumulation rates were used to calculate the age range of each interval as calendar dates before present. In addition to MAR, sedimentation rates were determined for specific time increments among estuary cores to identify changes over time. The CF:CS method assumes a constant sediment accumulation rate, whereas CRS determines MAR for each interval. The resulting chronology for the marsh-surface-core profiles determined the two methods agreed well with each other. The organic sediment MAR was determined from LOI, and the CRS total sediment MAR for each interval for the marsh surface sediments was determined by multiplying the total sediment MAR by the fraction of organic matter. The inorganic sediment MAR is then the difference between the total sediment MAR and the organic sediment MAR. Marsh accretion rate $(\mathrm{cm} / \mathrm{yr})$ was determined by dividing the maximum depth of measurable unsupported ${ }^{210} \mathrm{~Pb}$ by the difference between the surface date and the date at this depth.

\section{Water-Quality Data in the Bass Harbor Marsh Estuary and Tributaries}

\section{Nutrient Concentrations in Flood and Ebb Tides at the Estuary Outlet}

The median $\mathrm{NO}_{3}$ as nitrogen $\left(\mathrm{NO}_{3}-\mathrm{N}\right)$ concentration during the summers in 2011 and 2012 in the flood tide at the BHM Estuary outlet was $0.0097 \mathrm{mg} \mathrm{L}^{-1}$, and in the ebb tide it was $0.0075 \mathrm{mg} \mathrm{L}^{-1}$ (fig. 10). The median $\mathrm{NH}_{4}$ as nitrogen $\left(\mathrm{NH}_{4}-\mathrm{N}\right)$ concentration during the summers in 2011 and 2012 in the flood tide at the BHM Estuary outlet was $0.0250 \mathrm{mg} \mathrm{L}^{-1}$ nitrogen, and on the ebb tide it was $0.0200 \mathrm{mg} \mathrm{L}^{-1}$ nitrogen (fig. 10).

The median TDN concentration during the summers in 2011 and 2012 in the flood tide at the BHM Estuary outlet was $0.078 \mathrm{mg} \mathrm{L}^{-1}$, and on the ebb tide it was $0.110 \mathrm{mg} \mathrm{L}^{-1}$ (fig. 11). The median dissolved organic nitrogen (DON) concentration during the summers in 2011 and 2012 in the flood tide at the BHM Estuary outlet was $0.041 \mathrm{mg} \mathrm{L}^{-1}$ nitrogen, and on the ebb tide it was $0.087 \mathrm{mg} \mathrm{L}^{-1}$ nitrogen (fig. 11).

The median TDP concentration during the summers in 2011 and 2012 in the flood tide at the BHM Estuary outlet was $0.023 \mathrm{mg} \mathrm{L}^{-1}$, and on the ebb tide it was $0.020 \mathrm{mg} \mathrm{L}^{-1}$ (fig. 11).

\section{Nutrient Concentrations in Tributaries}

The median $\mathrm{NO}_{3}-\mathrm{N}$ concentration during the summers in 2011 and 2012 in Marshall Brook was $0.080 \mathrm{mg} \mathrm{L}^{-1}$ nitrogen, which was an order of magnitude higher than median $\mathrm{NO}_{3}$ concentrations in the other tributaries (fig. 12). 
Median concentrations of $\mathrm{NH}_{4}$ were highest in Adams Brook ( $0.043 \mathrm{mg} \mathrm{L}^{-1}$ nitrogen) and

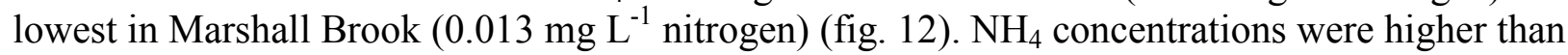
$\mathrm{NO}_{3}$ concentrations in Lurvey, Heath, and Adams Brooks, but substantially lower than $\mathrm{NO}_{3}$ concentrations in Marshall Brook. Median total organic nitrogen concentrations were highest in Adams Brook (0.69 $\mathrm{mg} \mathrm{L}^{-1}$ nitrogen) and lowest in Marshall Brook (0.29 $\mathrm{mg} \mathrm{L}^{-1}$ nitrogen) (fig. 13). The organic nitrogen fraction dominated the dissolved nitrogen fraction in all tributaries. Median total TDP concentrations were highest in Adams Brook $\left(0.019 \mathrm{mg} \mathrm{P} \mathrm{L}{ }^{-1}\right)$ and lowest in Marshall Brook (0.005 $\left.\mathrm{mg} \mathrm{P} \mathrm{L}^{-1}\right)$ (fig. 14). There was little seasonal variation in inorganic nitrogen or TDP concentrations; however, organic nitrogen concentrations tended to be higher during August and September than during May, June, and July (data are not shown but are accessible through the NWIS online database (U.S. Geological Survey, 2013b)).

\section{Continuously Monitored Specific Conductance at the Estuary Outlet}

Specific conductance measured at the estuary outlet varied between 1,000 and $50,000 \mu \mathrm{s} / \mathrm{cm}$ in both 2011 and 2012 (figs. 15A, 16A). The tidally forced reversing flow causes the specific conductance to rebound to levels associated with ocean waters (approximately $50,000 \mu \mathrm{s} / \mathrm{cm}$ ) during each flood tide. The overall seasonal pattern was for the specific conductance to be lowest on the ebb tides early in the spring and for specific conductance on the ebb tide to become progressively higher (saltier) throughout the summer. This overall pattern was punctuated by decreases in specific conductance associated with runoff following storms (figs. 15A and B, 16A and B). These depressions in ebb-tide specific conductance could persist for several days following large runoff events. Precipitation records from the McFarland Hill NADP site for the summers (June 1 through September 30) of 2011 and 2012 show a total of $31 \mathrm{~cm}$ in 2011 and $56.5 \mathrm{~cm}$ in 2012 (although $6.1 \mathrm{~cm}$ were recorded on September 30, 2012).

\section{Nutrient Loads in 2011 and 2012 and Turbidity Measurements}

\section{Tidal Nutrient Loads}

Nutrient loads in each flood tide and following ebb tide were estimated from hourly load data for summer 2011 and summer 2012. These load values were superimposed on plots of tidal elevations recorded in nearby Bar Harbor to illustrate the effect of tidal elevation on nutrient loads across the boundary between the ocean and the estuary at the estuary outlet. These loads were also plotted with daily precipitation recorded at the McFarland Hill NADP site to show the connection between precipitation and nutrients exported on the ebb tide. The net exchange during a sequential flood and following ebb tide were also plotted to illustrate how the pattern of net exchange changed during the course of the season.

The magnitude of tidal nutrient loads followed the cycle of spring and neap tides (being highest on spring tides and lowest on neap tides) but was generally greatest during late May and June (figs. 17A, 18A, 19A, 20A, 21A, 22A, 23A, 24A) when runoff was greatest (figs. 15B and 16B). Nutrient loads on ebb tides increased following major precipitation events (figs. 17B, 18B, 19B, 20B, 21 B, 22B, 23B, 24B) that, in turn, corresponded with periods of higher runoff recorded at the nearby Otter Creek (figs. 15B and 16B). Net tidal exchange (flood minus following ebb) of $\mathrm{NH}_{4}$ tended to be negative (ebb load greater than flood load) in late May and June and positive or neutral after that (figs. 17C, 18C). Net tidal exchange of $\mathrm{NO}_{3}$ was positive throughout the season in 2011, especially in September (fig. 19C), and in 2012 it was mostly 
negative before mid-June, neutral until mid- to late August, and positive after that (fig. 20C). Net tidal exchange of TDN was negative throughout most of 2011 (fig. 21C) and all of 2012

(fig. 22C). Net tidal exchange of total TDP was mostly negative in 2011 (fig. 23C) and neutral in most of 2012 (fig. 24C).

\section{Tidal, Watershed, and Precipitation Weekly Nutrient Loads in 2011 and 2012}

Weekly inputs of $\mathrm{NH}_{4}$ to the estuary in runoff and direct precipitation in 2011 and 2012 show large variability ranging from 0.33 to $20 \mathrm{~kg}$ nitrogen per week for runoff and from 0.0 to $2.3 \mathrm{~kg}$ nitrogen per week for precipitation (figs. 25 and 26). Tidal inputs and exports of $\mathrm{NH}_{4}$ to the estuary were usually much larger (by a factor of 10 or more) than inputs in runoff or direct precipitation, except during 2012 following periods of high runoff when tidal inputs and exports were only larger by a factor of about 2 to 3 (figs. 25 and 26). Ebb-tide $\mathrm{NH}_{4}$ exports from the estuary were greater than flood-tide inputs to the estuary until the end of June in 2011 and until mid-July in 2012; after that flood-tide inputs were greater than ebb-tide exports in 2011 or nearly identical to flood-tide inputs in 2012. In 2011, total $\mathrm{NH}_{4}$ exports from the estuary were greater than inputs until the end of June, and after that $\mathrm{NH}_{4}$ inputs were always greater than exports. The cumulative input-export increased steadily from mid-June through the end of September to $146 \mathrm{~kg}$ nitrogen, reflecting steady consumption of $\mathrm{NH}_{4}$ in the estuary during this period at a rate of about $1.5 \mathrm{~kg}$ nitrogen per day. In 2012, total $\mathrm{NH}_{4}$ exports from the estuary were generally less than inputs until mid-July, and after that inputs were generally greater than exports. The cumulative input-export in 2012 decreased markedly from late May through mid-June and then more slowly though mid-July. The cumulative input-export in 2012 increased steadily from midJuly through the end of September but remained negative $(-33 \mathrm{~kg})$ at the end of September, reflecting net export from the estuary. In 2012 the estuary was a net source to the ocean from May 17 to July 10, 2012, at an average rate of $1.8 \mathrm{~kg}$ nitrogen per day, and the estuary consumed $\mathrm{NH}_{4}$ from July 10 to September 25, 2012, at a rate of $0.69 \mathrm{~kg}$ nitrogen per day.

Weekly inputs of $\mathrm{NO}_{3}$ to the estuary in runoff and direct precipitation in 2011 and 2012 show large variability ranging from 0.90 to $39 \mathrm{~kg}$ nitrogen per week for runoff and from 0.0 to $6.9 \mathrm{~kg}$ nitrogen per week for precipitation (figs. 27 and 28). Tidal inputs were usually larger than inputs in direct precipitation or runoff (by factors ranging from about 2 to 20), except during spring 2012 when inputs from runoff and the flood tide were similar, or for the week ending June 26, 2012, when inputs in watershed runoff were 3 times higher than tidal inputs following a major runoff event shown in figure 16B (figs. 27 and 28). Flood-tide imports of $\mathrm{NO}_{3}$ to the estuary were greater than ebb-tide exports throughout 2011 and in all but one week in 2012. The cumulative $\mathrm{NO}_{3}$ inputs-exports increased steadily in both 2011 and 2012, illustrating a pattern of net consumption within the estuary of $1.9 \mathrm{~kg}$ nitrogen per day in 2011 and $1.7 \mathrm{~kg}$ nitrogen per day in 2012.

Weekly inputs of phosphorus $(\mathrm{P})$ to the estuary in runoff varied greatly among weeks in both years, ranging from 0.20 to $14 \mathrm{~kg} P$ per week, and inputs were less than $0.5 \mathrm{~kg} P$ per week from mid-July to early August in both years (figs. 29 and 30). Weekly phosphorus inputs in runoff were substantially lower in late May and June in 2011 than in 2012. Runoff measured at nearby Otter Creek during this period was very low in 2011(fig. 15B) compared with runoff in 2012 (fig. 16B). Tidal inputs of phosphorus to the estuary were larger than inputs in runoff and direct precipitation by more than a factor of 10 in most weeks in 2011 and 2012. In 2011, the cumulative inputs-exports curve was positive until mid-July, when it began to decline steadily until mid-August (fig. 29). In 2011, the estuary was a net sink (P was consumed) until mid-July, 
and from mid-July to mid-August the estuary was a net source to the ocean. From mid-August to the end of September inputs were generally balanced by exports. In contrast, in 2012 the estuary was a net sink in most weeks (fig. 30). The majority of cumulative export in 2012 occurred from late may through the end of June. Inputs were balanced by exports from late June though the end of July.

Weekly inputs of TDN to the estuary in runoff varied greatly among weeks in both years. In 2011 inputs ranged from 7.0 to $316 \mathrm{~kg}$ nitrogen per week, and inputs were lowest in July and mid-September (fig. 31). In 2012 inputs ranged from 10 to $550 \mathrm{~kg}$ nitrogen per week, and inputs were low from July through September with the exception of one week in August and one week in September (fig. 32). In 2011 the cumulative inputs-exports curve was negative until late August, after which it remained positive through the end of September (fig. 31), indicating that the estuary was a net sink of TDN for the season but that the estuary was a net source to the ocean from early June though mid-August. In 2012 the cumulative inputs-exports curve for TDN remained positive throughout the year (the estuary was a net sink) in spite of the fact that the weekly input-export of TDN was negative (the estuary was a net source) for 13 out of 18 weeks (fig. 32).

The ratios of watershed plus direct precipitation to tidal inputs of $\mathrm{NO}_{3}$ and $\mathrm{NH}_{4}$ to the estuary varied greatly during each year, from greater than 4 to less than 0.1 , and were highest when watershed runoff was highest and lowest during summer months when runoff was lowest (figs. 33 and 34). These ratios were substantially lower in 2011 (when they were always less than 1.0 for $\mathrm{NO}_{3}$ and less than or equal to 0.3 for $\mathrm{NH}_{4}$ ) when runoff was lower than in 2012. The ratio of runoff plus precipitation to tidal inputs was always higher for $\mathrm{NO}_{3}$ than for $\mathrm{NH}_{4}$ (figs. 33 and 34). Watershed runoff plus precipitation generally supplied proportionately more of the total inputs to the estuary of $\mathrm{NO}_{3}$ than these sources did for $\mathrm{NH}_{4}$. During the drier, summer months tidal inputs supplied proportionately more $\mathrm{NH}_{4}$ and $\mathrm{NO}_{3}$ to the estuary than they did in the spring. The ratio of TDN in runoff and direct precipitation to tidal TDN inputs to the estuary ranged from less than 0.1 to 2.1 in 2011 (fig. 35) and from 0.1 to 6.8 in 2012 (fig. 36). The ratio of TDP in runoff and direct precipitation to tidal TDP inputs to the estuary ranged from less than 0.01 to 0.26 in 2011 (fig. 35) and from 0.01 to 0.74 in 2012 (fig. 36).

\section{Turbidity Measured at the Estuary Outlet in 2012}

Turbidity was measured at the estuary outlet for most of the period from mid-July through the end of September in 2012 (fig. 37A). Turbidity was usually below 10 nephelometric turbidity units (NTU) except following a storm-and-runoff event in early September when it increased to about 40 NTU. Turbidity followed a regular pattern whereby it reached a minimum at the end of the flood tide and then increased rapidly during the beginning of the ebb tide, then more slowly during the majority of the ebb tide, and reached a maximum at the end of the ebb tide (fig. 37B). This pattern would suggest that the estuary is a source of suspended sediment to the ocean rather than the ocean being a source to the estuary during this summer period because there is typically a positive relation between turbidity and suspended sediment (Hannouche and others, 2011).

\section{Tidal, Watershed, and Precipitation Seasonal Total Nutrient Loads in 2011 and 2012}

$\mathrm{NH}_{4}-\mathrm{N}$ loads were similar between ebb and flood tides in both years, being slightly higher on the flood tides in 2011 and slightly higher on the ebb tides in 2012 (table 4). The positive residual of $150 \mathrm{~kg} \mathrm{NH}_{4}-\mathrm{N}$ in 2011 indicated that the estuary was a net sink, consuming 
$\mathrm{NH}_{4}$ (net uptake, absorption, or flocculation/sedimentation). The residual was slightly negative $(-37 \mathrm{~kg})$ in 2012 , indicating that during this period the estuary was a net source of $\mathrm{NH}_{4}-\mathrm{N}$ to the ocean. Direct precipitation was a minor source of $\mathrm{NH}_{4}-\mathrm{N}$ in both years, only about 1 percent of all inputs to the estuary. Runoff was of relatively minor importance (about 6 percent of all inputs and 30 percent of the residual) in 2011 but arguably more important in 2012, when it accounted for 10 percent of all inputs and was 1.7 times higher than the residual (table 4 ).

$\mathrm{NO}_{3}-\mathrm{N}$ loads were substantially larger in the flood tide than the ebb tide in 2011, but they were similar between flood and ebb tides in 2012 (table 4). The importance of tidal $\mathrm{NO}_{3}-\mathrm{N}$ inputs to the estuary in 2011, in comparison with 2012, is highlighted by the fact that in 2011 the ratio of tidal inputs to watershed inputs was about 3.5, whereas in 2012 the ratio was about 1.4. The residual was positive and large in relation to the absolute values of inputs and exports in both years, indicating that the estuary was a sink for $\mathrm{NO}_{3}-\mathrm{N}$. In both years the flood tide was the largest source of that $\mathrm{NO}_{3}-\mathrm{N}$ to the estuary. The ratio of precipitation to watershed runoff inputs of $\mathrm{NO}_{3}-\mathrm{N}$ to the estuary was higher than this ratio was for $\mathrm{NH}_{4}-\mathrm{N}$ inputs. $\mathrm{NO}_{3}-\mathrm{N}$ inputs in precipitation were 7 percent of total inputs to the estuary in 2011 and 8 percent in 2012.

TDP loads were similar between ebb and flood tides in both years. TDP inputs from watershed runoff were 6 percent of total inputs to the estuary in 2011 and 10 percent of total inputs in 2012 (table 4). The residuals were small in both years relative to the tidal loads, indicating that inputs were nearly balanced by exports and that the estuary was neither a net source or sink of TDP.

Organic nitrogen loads (TON) on the ebb tide were substantially larger than organic nitrogen loads on the flood tide in 2011 and 2012 (table 4). However, in both years, inputs of TON to the estuary were approximately equal to the difference between ebb and flood tides so that the residuals were small. Only a relatively small proportion (about 4 percent in 2011 and 15 percent in 2012) of the TON that enters the estuary in watershed runoff plus flood tide is lost (consumed or deposited) within the estuary. The net load with respect to the ocean, or ebb-flood, was $1,000 \mathrm{~kg}$ in 2011 and 1,900 in 2012, illustrating that BHM watershed is a net source of TON to the ocean. The ratio of ebb to flood loads was 1.6 in 2011, but it was about 4.0 in 2012 . TON export on the ebb tide was nearly identical in both years, but flood tide inputs were $1,600 \mathrm{~kg}$ in 2011 and $630 \mathrm{~kg}$ in 2012. Organic nitrogen composed the largest fraction (83 to 88 percent) of TDN in watershed runoff in both years and on the ebb tide during both 2011 (76 percent) and 2012 (71 percent). Organic nitrogen comprised 62 percent of TDN on the flood tide in 2011 and only 42 percent of TDN in 2012.

\section{Sea-Level Rise and Historical Changes in the Bass Harbor Marsh Estuary}

\section{Projected Changes in Inundated Area and Estuary Volume Under Three SLR Scenarios}

Bathymetry of the estuary was measured to facilitate the calculation of the volume of water during the highest tides. The resulting bathymetric map shows that that the deepest areas are near the estuary outlet and that there is a recognizable channel along the western edge in the widest portion of the estuary (fig. 38). Projected sea-level rise associated with ongoing climate warming will affect the area of land within the BHM estuary watershed that is inundated during the mean higher high water (MHHW) and mean lower low water (MLLW) and hence affect the vegetation and marsh area. At MHHW the inundated area increases from 25.7 hectares (ha) at the current condition to 77.5 ha or 202 percent in association with 100-cm SLR (table 5 and figs. 39A and B). This large increase in area occurs because the water level rises above the 
fringing marsh surface and floods a substantial portion of the existing marsh at MHHW. If sea level were to rise by $200 \mathrm{~cm}$, the inundated area at MHHW would increase by over 400 percent, flooding all of the existing marsh, and would extend into peripheral forest areas that are not currently mapped as marsh (fig. 39A). There would be major increases in inundated areas along the entire length of the estuary but particularly in the north (on the eastern side of the estuary) and in the south (on the western side of the estuary) (fig. 39A).

At MLLW the inundated area increases from 21.6 ha at the current condition to 26.7 ha (a 24-percent increase) in association with 100-cm SLR (table 5 and fig. 39B). Given 200-cm SLR, all of the existing Spartina marsh adjacent to the estuary would be flooded at MLLW (fig. 39B). In other words, after 200-cm SLR the current marsh would be open water under almost all tidal conditions. Flooding to this extent currently occurs only under the very highest spring tides, but after $50 \mathrm{~cm}$ of SLR it would occur on average every other day. The uncertainty about these estimates is shown graphically with inundated areas at MHHW for 200-cm SLR as the 95percent upper and lower confidence limits using the reported lidar accuracy of $\pm 26 \mathrm{~cm}$ (fig. 39C).

The volume of water in the estuary at MHHW, under an assumption of no change in existing estuary bathymetry or fringing marsh elevation, is projected to increase markedly under SLR (table 5). At MHHW, the estuary volume increases from 176,000 cubic meters $\left(\mathrm{m}^{3}\right)$ in the current conditions to $473,000 \mathrm{~m}^{3}$ or 169 percent in association with $100-\mathrm{cm}$ SLR and to $1,130,000 \mathrm{~m}^{3}$ or 543 percent with $200-\mathrm{cm}$ SLR. At MLLW, the estuary volume increases from $56,800 \mathrm{~m}^{3}$ in the current conditions to $203,000 \mathrm{~m}^{3}$ or 257 percent in association with $100-\mathrm{cm}$ SLR and to $559,000 \mathrm{~m}^{3}$ or 543 percent with $200-\mathrm{cm}$ SLR.

The projected changes in inundated areas and estuary water volumes estimated in this report were calculated with the simplifying assumption that no sediment accretion occurred (that is, the estuary bottom and marsh-surface elevations were fixed at their current elevations). It is recognized that sediment accretion will occur; in fact, analysis of sediment chronologies described below indicates that the marsh-surface elevation appears to have kept pace with SLR of about $2.0 \mathrm{~mm} / \mathrm{yr}$ in this area during the last 100 years (National Oceanic and Atmospheric Administration, 2013). However, increases in the rate of SLR in this area since 1970 (Sallenger and others, 2012) and the projected acceleration in sea-level rise over the next century (by as much as a factor of 10) (Parris and others, 2012) may substantially exceed the rate of sediment accretion in this tidally restricted estuary because of a lack of sediment supply. Therefore, under a worst-case scenario of 200-cm of SLR by 2100 (Parris and others, 2012) the observed marshsurface sediment accretion rates would not begin to keep up, and the validity of these estimates of changes in inundation and volume would be enhanced. Because sediment accretion will occur and because moderate rates of SLR are likely, the potential increases in the area of inundation and in estuary water volume presented here are somewhat exaggerated and shown for conceptual illustration rather than quantitative prediction.

\section{Historical Changes in Estuary Area Based on a GIS Analysis of Aerial Photographs}

It is evident that the estuary has widened since the earliest aerial photographs were taken in 1944. The widening is presumably related to erosion and collapse of channel banks. Widening of the estuary channel is especially apparent in the widest portions of the estuary and has resulted in an overall increase in the surface area of the estuary (fig. 40). The increase in estuary area is estimated to be 1.4 ha or a 7-percent increase from 1944 to 2010 (table 6). The change in estuary surface area (channel widening) has not been uniform over time. The channel widened by 
5 percent between 1944 and 1955 and by an additional 2 percent from 1955 to 2010. Marsh surface area decreased by about 0.9 ha or 3.1 percent from 1944 to 2010. Estuary widening associated with rising sea level has been reported for another marsh complex in the Chesapeake Bay area (Tiner and Bergquist, 2003; Kearney and others, 1988).

\section{Bass Harbor Marsh Estuary and Marsh Surface Cores: Summary of $210 \mathrm{~Pb}$ Chronology and Mass Accumulation Rates of Sediment and Organic Matter}

\section{${ }^{210} \mathrm{~Pb}$ in Estuary Surface Cores}

The ${ }^{210} \mathrm{~Pb}$ analysis of the four cores collected in the estuary indicated that the mass accumulation rates were very similar, so only the results from one core (BHM.01) are discussed here. ${ }^{210} \mathrm{~Pb}$ activity decreases with increasing depth in sediment to the supported activity defined by ${ }^{226} \mathrm{Ra}$ at the depths greater than $22 \mathrm{~cm}$ (fig. 41A). The decrease in unsupported activity does not follow a simple exponential decrease with depth, as illustrated by plotting the natural log of unsupported ${ }^{210} \mathrm{~Pb}$ in relation to cumulative sediment mass (fig. 41B). An exponential decrease is expected for decay of the unsupported ${ }^{210} \mathrm{~Pb}$ activity over time because of its characteristic decay rate (with a half life of 22.3 years in a system with constant sediment accumulation rate). Unsupported ${ }^{210} \mathrm{~Pb}$ results from emanation of ${ }^{222} \mathrm{Rn}$ from continental land masses, decay in the atmosphere to ${ }^{210} \mathrm{~Pb}$, and subsequent deposition onto the estuary surface and watershed, followed by scavenging by sediment particles and deposition that are then deposited on the estuary bed. The zone of near constant ${ }^{210} \mathrm{~Pb}$ activity between 0 and $4 \mathrm{~cm}$ may reflect a period of increased accumulation or mixing of the sediment due to physical processes, such as episodic resuspension and redeposition. The presence of ${ }^{7} \mathrm{Be}$ in the top interval only $(0-2 \mathrm{~cm})$ and not below (data not shown) suggests that sediment mixing is minor. The source of ${ }^{7} \mathrm{Be}$ is atmospheric deposition to the estuary surface and rapid scavenging to suspended particulate material. Because of its 53-day half-life, the ${ }^{7} \mathrm{Be}$ in the $0-2-\mathrm{cm}$ depth interval can only occur if some fraction of the sediment was in the water column within the past 200 days.

The nonlinear profile of unsupported ${ }^{210} \mathrm{~Pb}$ in relation to depth indicates a change in sediment accumulation rate at this site, and is particularly evident from the large change in slope below $16 \mathrm{~cm}$ (fig. 41B), consistent with an increase in sedimentation rate above. Sediment MAR in relation to depth was determined from the ${ }^{210} \mathrm{~Pb}$ profile using the constant rate of supply, CRS, method (Appleby and Oldfield, 1992). The CRS method assumes a constant rate of input of unsupported ${ }^{210} \mathrm{~Pb}$ activity per gram and determines a sediment accumulation rate for each core interval by mass balance (in units of grams per square centimeter per year, $\mathrm{g} / \mathrm{cm}^{2} / \mathrm{yr}$ ). The method allows for determining variations in rate of sediment accumulation with depth. The age of the midpoint of each sediment interval is determined for each interval at its mid-depth and subtracted from the core collection date to assign a calendar year for each interval (fig. 42A). The resulting dates and MARs from the CRS method, depicted in figure 42B, show a nearly constant sediment accumulation rate over the upper $10 \mathrm{~cm}$ (to 1970) and a large decrease in MAR with increasing depth below. The propagated uncertainty in the MAR for the deepest interval indicates that ${ }^{210} \mathrm{~Pb}$-derived dates at depth less than $19 \mathrm{~cm}$ (before 1900) are unreliable. Nonetheless, the ${ }^{210} \mathrm{~Pb}$ data are best described as a large increase in sedimentation that occurred from 1930 to 1980 , followed by a relatively constant rate. Core sectioning at intervals of $1 \mathrm{~cm}$, 
for example, at depths less than $20 \mathrm{~cm}$ could improve the detection of the occurrence and timing of the apparent change in sedimentation.

\section{${ }^{137}$ Cs in Estuary Surface Cores}

In this core, ${ }^{137} \mathrm{Cs}$ activity has a slight maximum in activity in the $10-13-\mathrm{cm}$ depth interval (fig. 43), and then the activity decreases as depth increases below the peak, with measurable activity present to $19-22 \mathrm{~cm}$. The ${ }^{210} \mathrm{~Pb}$-derived dates for the depth interval of maximum ${ }^{137}$ Cs activity range from 1969 to 1982 , with a mid-interval date of 1976, all later than the known fallout input maximum of 1963. In addition, measurable ${ }^{137} \mathrm{Cs}$ is present to at least 19- $22 \mathrm{~cm}$. The ${ }^{210} \mathrm{~Pb}$-derived dates for this $19-22 \mathrm{~cm}$ depth range precede the onset of atmospheric fallout in 1952 by 30 or more years. Postdepositional mobility of ${ }^{137} \mathrm{Cs}$, independent of sediment particles, has been documented in sediments with high organic-matter contents and high rates of organic-matter degradation. Remobilization of ${ }^{137} \mathrm{Cs}$ results from desorption from clays by cation exchange for $\mathrm{NH}_{4}$ ions produced during diagenesis. Subsequent diffusion of dissolved ${ }^{137} \mathrm{Cs}$ results in deeper penetration of the radionuclide and an upward migration of the activity maximum (Anderson and others, 1987). The poor agreement between ${ }^{137} \mathrm{Cs}$ horizons with ${ }^{210} \mathrm{~Pb}$ chronology is consistent with ${ }^{137} \mathrm{Cs}$ remobilization. As a result, ${ }^{137} \mathrm{Cs}$ cannot be used reliably in this core to constrain the sediment chronology.

\section{Estimating Mass Accumulation Rates Using Estuary Sediment Cores}

Figures showing the similar results from the other three cores (BHM.02, BHM.03, and BHM.04) are shown (figs. 44, 45, 46). A comparison of the ${ }^{210} \mathrm{~Pb}$ CRS method dates and sediment MARs shows similar chronologies and mass accumulation rates by depth for all four cores, (fig. 47). The upper $20 \mathrm{~cm}$ at these sites was deposited over the last 100 years. Sites BHM.01, BHM.02, and BHM.04 have similar chronology in the upper $20 \mathrm{~cm}$. Sediment MARs (accounting for compaction) have increased three-fold during the past 100 years. A comparison of the unsupported ${ }^{210} \mathrm{~Pb}$ and ${ }^{137} \mathrm{Cs}$ activity for all four cores shows that the activity and inventory of ${ }^{210} \mathrm{~Pb}$ are lowest for site BHM.03 (near the estuary outlet) and that the other three sites are similar to each other (fig. 48 ). The ${ }^{137} \mathrm{Cs}$ inventory decreases with proximity to the seaward end of the estuary, likely resulting from cation exchange of Cs off sediments when higher salinities are encountered. Maxima in ${ }^{137} \mathrm{Cs}$ activity are broad and not well defined at sites BHM.01, BHM.02, and BHM.04, and are not present at site BHM.03. Mobility of Cs, redistribution of sediment within the estuary, and lag in delivery from the watershed may contribute to absence in distinct ${ }^{137} \mathrm{Cs}$ maxima corresponding to the period of maximum ${ }^{137} \mathrm{Cs}$ fallout delivery (1963).

A summary of the mass accumulation rates (MARs) determined for the four cores collected from the estuary in 2009 shows consistently high rates of 0.09 to $0.11 \mathrm{~g} / \mathrm{cm}^{2} / \mathrm{yr}$ for 1980 to 2009 (table 7). The MARs are lowest prior to the decades from 1960 to 1980 which, in turn, have MARs lower than those during the period 1980 to 2009 (table 7). Similarly, the sediment accumulation rates were highest, 0.4 to $0.5 \mathrm{~cm} / \mathrm{yr}$, during 1980 to 2009 , intermediate during 1960 to 1980 , and lowest, 0.1 to 0.2 , prior to 1960 .

Organic content of the estuary sediments is comparable among the four core profiles in the upper $40 \mathrm{~cm}$ (fig. 49). Organic content varies little in the upper $18 \mathrm{~cm}$, ranging between 14 to 17 percent among the four core profiles. This zone corresponds to sediments deposited during the last 80 to 100 years (fig. 47). Organic content of the sediments decreases with increasing depth below $16 \mathrm{~cm}$, with a greater decrease observed in core BHM.01 than in the other cores. It is unknown if the decrease corresponding to increasing depth is the result of organic-matter 
decomposition over time or if it reflects recent deposition of sediment with relatively high organic content. Organic content increases sharply below $40 \mathrm{~cm}$ in cores BHM.03 and BHM.04. No increase was observed below $40 \mathrm{~cm}$ in BHM.01 and a small increase was observed in BHM.02. The depth of this increase is $20 \mathrm{~cm}$ or more below the ${ }^{210} \mathrm{~Pb}$-dated section. Thus, the increase in organic matter occurs in sediments that are at least 200 years old. Deeper cores and alternate dating tools would be needed to characterize the timing and possible source of the increase in organic matter. The increase in organic content at depth may reflect sediment of different sources or may be the result of a relict marsh deposit. Organic-matter mass accumulations were calculated for the intervals dated by ${ }^{210} \mathrm{~Pb}$ (table 7). Because the organic matter content does not vary with depth in the ${ }^{210} \mathrm{~Pb}$ date intervals, the calculated organic MARs are greater in shallower sediments as a result of the increase in total sediment MAR (fig. 47).

\section{Marsh Sediment Cores}

The marsh-surface sediment cores had much higher organic matter concentrations than the estuary sediments and account for more than 80 percent of the sediment mass at the core tops (figs. 50 to 54). Sediments at site BHM.S1 had the lowest organic fraction, with organic content accounting for up to 50 percent (fig. 50). This site was located at the edge of the marsh on the berm adjacent to the estuary and may thus receive a greater input of inorganic sediment than the other marsh-core sites. Organic content was relatively constant in the upper $12 \mathrm{~cm}$ of each core. Organic content decreased with depth in BHM.S1 with the exception of small increase between 24 and $28 \mathrm{~cm}$ (fig. 50). In BHM.S2, organic content decreased sharply at $12 \mathrm{~cm}$ to $20 \mathrm{~cm}$ below the surface, and below that level, organic content was relatively constant and in the range of the estuary sediment cores (fig. 51). Organic content at sites BHM.S3, BHM.S4a, and BHM.S4b also decreased below a constant zone in the upper part of the cores (figs. 52 to 54). In all three, a subsurface minimum occurs that is underlain by a zone where organic content increases with increasing depth. It is unknown if these zones of low organic content are the result of increased input of inorganic sediment to the marsh or a hiatus in the marsh accretion. The organic content in relation to depth for all cores is plotted in figure 55 to provide comparison among cores.

${ }^{210} \mathrm{~Pb}$ profiles of the five marsh surface core show a near-exponential decrease in activity with increasing depth (figs. 50 to 54). Unsupported ${ }^{210} \mathrm{~Pb}$ activity extends to $22 \mathrm{~cm}$ at sites BHM.S1, BHM.S4a, and BHM.S4b, all on the east side of the estuary (fig. 5). The ${ }^{210} \mathrm{~Pb}$ activities in the top intervals of the marsh-surface cores are a factor of 5 or higher than in the estuary sediments. This difference may in part reflect dilution of ${ }^{210} \mathrm{~Pb}$ in the estuary inorganic sediments that have a higher bulk density than the marsh surface sediment. The unsupported ${ }^{210} \mathrm{~Pb}$ inventories for the entire profiles (table 8) range from 0.43 to 1.33 becquerels per square centimeter $\left(\mathrm{Bq} / \mathrm{cm}^{2}\right)$. By comparison, the integrated unsupported ${ }^{210} \mathrm{~Pb}$ in the estuary cores ranged from 0.27 to $0.44 \mathrm{~Bq} / \mathrm{cm}^{2}$ and averaged $0.37 \pm 0.07$. The unsupported ${ }^{210} \mathrm{~Pb}$ inventories should be equal if the unsupported ${ }^{210} \mathrm{~Pb}$ is only from fallout directly to the sediment surface. Transport of sediment and ${ }^{210} \mathrm{~Pb}$ from other sources in the estuary and watershed and deposition at the coring sites would increase the ${ }^{210} \mathrm{~Pb}$ inventory, whereas low values may reflect transport of a fraction of the atmospheric ${ }^{210} \mathrm{~Pb}$ away from the coring sites.

Dates calculated by the CRS method for the marsh-surface cores decreased somewhat uniformly with increasing depth in all cores (figs. 50 to 54), with the depth-curve dates for the five profiles overlapping one another (fig. 55). A summary of the CRS MARs for total sediment (organic plus inorganic mass) determined for the five cores collected from the marsh surface (east and west sides of the estuary) in 2011 show rates ranging from 0.018 to $0.036 \mathrm{~g} / \mathrm{cm}^{2} / \mathrm{yr}$ 
from the early 1900s to 2011 (table 8); the average for the five sites is $0.025 \pm 0.007 \mathrm{~g} / \mathrm{cm}^{2} / \mathrm{yr}$. Total sediment MARs determined by the CRS method were somewhat uniform with depth at sites BHM.S2, BHM.S3, and BHM.S4b. The total sediment MAR for site BHM.S1 varied irregularly by over a factor of three over the dated core profile, and hd the highest rates in the upper two depth intervals. The total sediment MAR in BHM.S4a had a subsurface maximum at 12 to $14 \mathrm{~cm}$. Similarly, the MAR of organic matter also had a subsurface maximum in this depth range, as did the inorganic sediment MAR. Dates derived using the CF:CS method for an inorganic sediment basis (not shown) agreed very well with the CRS dates. This agreement is consistent with constant accumulation rates over time at each site.

Organic matter MAR was calculated for each core interval by multiplying the total sediment MAR (from the CRS method) by the interval fraction of organic sediment. Among the five marsh surface cores, the organic matter MAR for the entire ${ }^{210} \mathrm{~Pb}$ dated profile has a narrow range from 0.014 to $0.018 \mathrm{~g} / \mathrm{cm}^{2} / \mathrm{yr}$, averaging $0.016 \pm 0.002 \mathrm{~g} / \mathrm{cm}^{2} / \mathrm{yr}$. The organic-matter MAR shows similar variability in each core to the total sediment MAR, with the exception of site BHM.S1, where the total sediment MAR varies much more than the organic MAR (fig. 55). The similarity in trends of total and organic MAR is indicative of organic-matter accumulation dominating marsh accretion at all sites except BHM.S1. The increase in MAR in the 12-14-cm interval in BHM.S4a reflects a period of somewhat higher mass accumulation at this site. The organic sediment MAR for the other sites varies little with depth, suggesting a near-constant accumulation of organic matter in the marsh over time. Organic-matter accumulation is likely dominated from plant growth in the marsh. Inorganic sediment MAR is defined as the difference between total sediment MAR and organic sediment MAR. The inorganic sediment MAR at BHM.S1 displays a wide variability in rate with depth similar to that observed for total sediment MAR (fig. 50), indicating that the transport and delivery of inorganic sediment to the marsh edge varies widely over time. By comparison, inorganic-sediment mass accumulation rate varies little with depth (and thus over time) at all other sites, which are located farther from the estuary (figs. 51 to 55 ).

The marsh accretion rate, in $\mathrm{cm} /$ year, was calculated from the thickness of the dated section divided by the difference between the surface age and the ${ }^{210} \mathrm{~Pb}$ age at the bottom. For example, in core BHM.S1 the 24-cm horizon is dated at 1902, so $24 \mathrm{~cm} /(2011-1902)=$ $0.22 \mathrm{~cm} / \mathrm{yr}$. The range and average accretion rate over last 100 years is 0.14 to $0.22 \mathrm{~cm} / \mathrm{yr}$ $(0.18 \pm 0.03 \mathrm{~cm} / \mathrm{yr}$ or $1.8 \pm 0.3 \mathrm{~mm} / \mathrm{yr}$ average) (table 8$)$. SLR based on the NOAA tide gage in nearby Bar Harbor between the years 1947 through 2011 is $2.18 \pm 0.26 \mathrm{~mm} / \mathrm{yr}$ (National Oceanic and Atmospheric Administration, 2013). The data indicate that marsh accretion has kept up with SLR in this marsh. A summary of the sediment accretion rates determined for the five cores collected from the marsh surface (east and west sides of the estuary) in 2011 show generally higher rates of 0.20 to $0.29 \mathrm{~cm} / \mathrm{yr}$ for the period between 1980 to 2011 than for the period before 1980 (table 9). The sediment accretion rates are lower $(0.06$ to $0.25 \mathrm{~cm} / \mathrm{yr})$ for the earlier part of the 20th century than for the late 20 th and early 21 st centuries.

The profiles of ${ }^{137}$ Cs show distinct subsurface maxima at sites BHM.S1, BHM.S2, BHM.S4a and BHM.S4b (figs. 50 to 55). The date ranges for the depth of the ${ }^{137} \mathrm{Cs}$ for sites BHM.S1 and BHM.S4b agree with the maximum fallout delivery of ${ }^{137}$ Cs from 1963 to 1964 . The ${ }^{210} \mathrm{~Pb}$ date for the depth of the ${ }^{137} \mathrm{Cs}$ peak in BHM.S4a precedes 1963 by 9 to 14 years, whereas the date of the peak interval in BHM.S2 is 8 to 13 years later than 1963. The disparity between the dates of the intervals with the observed ${ }^{137} \mathrm{Cs}$ subsurface peak in these two cores is partly the result of the uncertainty involved in ${ }^{210} \mathrm{~Pb}$ dating, as the peaks occur in an interval that 
is shallower in BHM.S2 and deeper in BHM.S4b than the interval that contains the 1963 horizon defined by ${ }^{210} \mathrm{~Pb}$. The ${ }^{137} \mathrm{Cs}$ profile for site BHM.S3 has two distinct subsurface maxima (fig. 52). The processes causing this ${ }^{137} \mathrm{Cs}$ profile are unknown.

\section{Summary}

The U.S. Geological Survey and Acadia National Park collaborated on a study of nutrient inputs into Bass Harbor Marsh estuary to better understand ongoing eutrophication, oceanderived nutrient inputs, and potential management solutions. This study included the estimation of ammonium, nitrate, total dissolved nitrogen, and total dissolved phosphorus loads to the estuary derived from runoff within the watershed and from tidal inputs during summer 2011 and summer 2012. Tidal outputs were also monitored, and nutrient inputs from direct precipitation to the estuary were estimated. Specific conductance, water temperature, and turbidity were monitored at the estuary outlet. The study included an analysis of the potential effects of projected sea-level rise on the inundated area and estuary volume. Historical aerial photographs were used to investigate the possibility that the estuary channel has widened over time. The study also included the analysis of sediment cores, collected from the estuary and fringing marsh surfaces, to assess sediment mass accumulation rates.

Nutrient loads into the estuary on the flood tide and out of the estuary on the ebb tide followed the cycle of spring and neap tides (being largest on spring and smallest on neap tides) but were generally largest during late May and June when runoff was also largest. Nutrient loads on ebb tides increased following major precipitation that, in turn, corresponded with periods when relatively large volumes of runoff were recorded at the nearby Otter Creek. Net tidal exchange (flood minus following ebb) of ammonium tended to be negative (ebb load greater than flood load) in late May and June and positive or neutral after that. Net tidal exchange of nitrate was positive throughout the season in 2011, especially in September, and, in 2012, it was mostly negative before mid-June, neutral until mid- to late August, and positive after that. Net tidal exchange of total dissolved nitrogen was usually negative. Net tidal exchange of total dissolved phosphorus was mostly negative in 2011 and neutral in most of 2012.

Tidal inputs and exports of ammonium to the estuary were usually much larger than inputs in runoff or direct precipitation, except during 2012, following periods of high runoff, when tidal inports and exports were only larger by a factor of about 2 to 3. In 2011 the estuary was a net sink for ammonium, whereas in 2012 it was a small net source of ammonium to the ocean. Tidal inputs of nitrate to the estuary were usually much larger than inputs in runoff or direct precipitation. The estuary was a net sink for nitrate during June through September in 2011 and 2012.

In 2011, the estuary was a net sink for total dissolved phosphorus (phosphorus was consumed) until mid-July, and from mid-July to mid-August the estuary was a net source to the ocean. In contrast, in 2012 the estuary was a net sink in most weeks. The majority of cumulative export from the estuary to the ocean in 2012 occurred from late May through the end of June. Inputs were balanced by outputs from late June through the end of July. In 2011, the estuary was a net sink of total dissolved nitrogen for the season, but the estuary was a net source to the ocean from early June though mid-August. In 2012 the estuary was a net sink for the summer season in spite of the fact that the weekly input-export of total dissolved nitrogen was negative (the estuary was a net source) for 13 out of 18 weeks.

The weekly ratios of watershed plus direct precipitation to tidal inputs of nitrate and ammonium to the estuary varied greatly during each year, from greater than 4 to less than 0.1 . 
These ratios were highest when watershed runoff was greatest and were least during summer months when runoff was least. These ratios were substantially lower in 2011 (when they were always less than 1.0 for nitrate and greater than or equal to 0.3 for ammonium) when runoff was lower than in 2012. The ratio of runoff plus precipitation to tidal inputs was always higher for nitrate than for ammonium. Watershed runoff plus precipitation generally supplied proportionately more of the total inputs to the estuary of nitrate than these sources did for ammonium.

For the 2011 and 2012 summers, estimated tidal inputs of ammonium to the estuary were more than 7 times greater than the combined inputs in watershed runoff and precipitation. In 2011, tidal inputs of nitrate were about 3 times greater than watershed plus precipitation inputs, and in 2012 , tidal inputs were only slightly greater than watershed plus precipitation inputs. In 2011, tidal inputs of total organic nitrogen were greater than watershed inputs by a factor of 1.6. By contrast, in 2012, inputs of total organic nitrogen in watershed runoff were much greater than tidal inputs, by a factor of 3.6. For the 2011 and 2012 seasons, tidal inputs of total dissolved phosphorus to the estuary were more than seven times greater than inputs in watershed runoff. It is evident that during the summer tidal inputs of inorganic nitrogen and total dissolved phosphorus to the estuary exceed inputs from watershed runoff and precipitation.

Sea-level rise (SLR) projections for the 21st century are highly uncertain, but under the scenarios investigated in this report (sea-level-rise predictions of 50, 100, and 200 centimeters $(\mathrm{cm})$ ), there would likely be major changes in inundated area and estuary volume. We estimated that a $100-\mathrm{cm}$ sea-level rise would result in approximately $60 \mathrm{~cm}$ of water-level rise within the estuary, an increase of 200 percent in inundated area at mean higher high water. The increase in estuary volume associated with this 100 -cm SLR projection would be 169 percent. For SLR projections of 50 and $100 \mathrm{~cm}$ the area of inundation at mean lower low water would be only 12 and 24 percent, respectively, but a sea-level rise of $200 \mathrm{~cm}$ would increase the area of inundation at mean lower low water by more than 300 percent. Rising sea level would increase the duration of the flood tide and the residence time of ocean-derived nutrients within the estuary.

Analysis of historical aerial photographs of the Bass Harbor Marsh estuary and surrounding areas showed that the channel has apparently widened since 1944. The estuary channel area increased by about 7 percent from 1944 to 2010, mostly between 1944 and 1955. The apparent erosion of channel banks may be the source of sediment responsible for an acceleration of sedimentation within the estuary and could explain shoaling that has been reported anecdotally.

A summary of the mass accumulation rates (MARs) determined for the four cores collected from the estuary in 2009 show consistently high rates of 0.09 to 0.11 grams per square centimeter per year $\left(\mathrm{g} / \mathrm{cm}^{2} / \mathrm{yr}\right)$ for 1980 to 2009 . The mass accumulation rates are somewhat lower, 0.06 to $0.09 \mathrm{~g} / \mathrm{cm}^{2} / \mathrm{yr}$, in the preceding decades (1960 to 1980) and lower still, 0.02 to $0.05 \mathrm{~g} / \mathrm{cm}^{2} / \mathrm{yr}$, during the decades before that. Similarly the sediment accumulation rates were highest, 0.4 to 0.5 centimeter per year (cm/yr), during 1980 to 2009 , intermediate during 1960 to 1980 , and lowest, 0.1 to 0.2 , prior to 1960 . A summary of the constant rate of supply (determined by the ${ }^{210} \mathrm{~Pb}$ dating method) (CRS) mass accumulation rates (MARs) for total sediment (organic plus inorganic mass) determined for the five cores collected from the marsh surface (east and west sides of the estuary) in 2011 shows rates ranging from 0.018 to $0.036 \mathrm{~g} / \mathrm{cm}^{2} / \mathrm{yr}$ from the early 1900s to 2011 ; the average for the five sites is $0.025 \pm 0.007 \mathrm{~g} / \mathrm{cm}^{2} / \mathrm{yr}$. A summary of the sediment accretion rates determined for the five cores collected from the marsh surface (east and west sides of the estuary) in 2011 shows generally higher rates of 0.20 to $0.29 \mathrm{~cm} / \mathrm{yr}$ from around 
1980 to 2011 than before 1980 . The sediment accretion rates on the marsh surface in the early part of the 20th century were lower than in the late 20th and early 21 st centuries by 0.06 to $0.25 \mathrm{~cm} / \mathrm{yr}$. The sharp increases in organic matter content that were observed deeper than $40 \mathrm{~cm}$ in two of the four estuary cores occurred in sediments that were more than 200 years old and may reflect a different sediment source or a relict marsh deposit. Similarly, we observed increases in organic matter content between 25 - and 40-cm depth in two of the four marshsurface locations that were cored.

\section{References Cited}

American Public Health Association, 1998, Standard methods for the examination of water and wastewater (20th ed.): Washington, D.C., American Public Health Association.

Anderson, B.T., Hayhoe, Katharine, and Liang, X.Z., 2010, Anthropogenic-induced changes in twenty-first century summertime hydroclimatology of the northeastern US: Climatic Change, v. 99, p. $403-423$.

Anderson, I.C., Tobias, C.R., Neikirk, B.B., and Wetzel, R.L., 1997, Development of a processbased nitrogen mass balance model for a Virginia (USA) Spartina alterniflora salt marshImplications for net DIN flux: Marine Ecology Progress Series, v. 159, p. 13-27.

Anderson, R.A., Schiff, S.L., and Hesslein, R.H., 1987, Determining sediment accumulation and mixing rates using ${ }^{210} \mathrm{~Pb},{ }^{137} \mathrm{Cs}$ and other tracers-Problems due to postdepositional mobility or coring artifacts: Canadian Journal of Fisheries and Aquatic Sciences, v. 44, p. 231-250.

Appleby, P.G., and Oldfield, Frank., 1992, Application of ${ }^{210} \mathrm{~Pb}$ to sedimentation studies, chap. 21 in Ivanovich, Miro, and Harmon. R.S., eds., Uranium-series disequilibrium-Application to earth, marine, and environmental sciences (2d ed.): Oxford, Clarendon Press, p. 731-778.

Balch, W.M., Drapeau, D.T., Bowler, B.C., and Huntington, T.G., 2012, Step-changes in the physical, chemical and biological characteristics of the Gulf of Maine, as documented by the Gulf of Maine North Atlantic time series (GNATS): Marine Ecological Progress Series, v. 450, p. 11-35.

Bindoff, N.L., Willebrand, Jürgen, Artale, Vincenzo, Cazenave, Anny, Gregory, J.M., Gulev, Sergey, Hanawa, Kimio, Le Quéré, Corrine, Levitus, Sydney, Nojiri, Yukihiro, Shum, C.K., Talley, L.D., and Unnikrishnan, A.S., 2007, Observations-Oceanic climate change and sea level, in Solomon, S., Qin, D., Manning, M., Chen, Z., Marquis, M., Averyt, K.B., Tignor, M. and Miller, H.L., eds., Climate change 2007-The physical science basis Contribution of Working Group I to the Fourth Assessment Report of the Intergovernmental Panel on Climate Change: [Cambridge, United Kingdom, and New York, N.Y., Cambridge University Press, p. 385-432.

Bing, 2010, Bass Harbor Marsh estuary channel and fringing marsh, [44 $1527.45 \mathrm{~N}$ latitude, -68 2039.73 W longitude]: Seattle, Wash., Microsoft Corp., accessed January 7, 2013, at http://www.bing.com/maps/\#Y3A9cmM5ZG42OTk0OTJyJmx2bD0xNSZzdHk9YiZxPTQ0JT I1MjAxNSUyNTIwMjcuNDUIMjUyMC02OCUyNTIwMjAlMjUyMDM5Ljcz

Boyer, E.W., and Howarth, R.W., 2002, The nitrogen cycle at regional to global scales: New York, Springer, $532 \mathrm{p}$.

Bricker, S.B., Clement, C.G., Pirhalla, D.E., Orlando, S.P., and Farrow, D.R.G., 1999, National estuarine eutrophication assessment-Effects of nutrient enrichment in the nation's estuaries: Silver Spring, Md., National Oceanic and Atmospheric Administration, National Ocean Service, Special Projects Office and the National Centers for Coastal Ocean Science, 71 p. 
Callender, Edward., and Robbins, J.A., 1994, Transport and accumulation of radionuclides and stable elements in a Missouri River reservoir: Water Resources Research, v. 29, p. 1787-1804.

Childers, D.L., 1994, Fifteen years of marsh flumes-A review of marsh-water column interactions in Southeastern USA estuaries, in Mitsch, W.J., ed., Global Wetlands-Old World and New: New York, Elsevier Science, p. 277-293.

Childers, D.L., Day, J.W., Jr., and McKellar, H.N., Jr., 2000, Twenty more years of marsh and estuarine flux studies-Revisiting Nixon (1980), in Weinstein, M., Kreeger, D.A., eds., Concepts and Controversies in Tidal Marsh Ecology: Dordrecht, Kluwer Academic Publishing, p. 391-423.

Cloern, J.E., 1996, Phytoplankton bloom dynamics in coastal ecosystems-A review with some general lessons from sustained investigation of San Francisco Bay, California: Reviews of Geophysics, v. 34, p. 127-168.

Culbertson, C.W., Huntington, T.G., and Caldwell, J.M., 2007, Nutrient enrichment in estuaries from discharge of shallow ground water, Mt. Desert Island, Maine: U.S. Geological Survey Scientific Investigations Report 2007-5188, 34 p.

Cutshall, N.H., Larsen, I.L., and Olsen, C.R., 1983, Direct analysis of ${ }^{210} \mathrm{~Pb}$ in sediment samples-Self-absorption corrections: Nuclear Instruments and Methods in Physics Research, v. 306, p. 309-312.

Dame, R.F., 1994, The net flux of materials between marsh-estuarine systems and the sea-The Atlantic coast of the United States, in Mitsch, W.J., ed., Global wetlands - Old world and new: Amsterdam, Elsevier, p. 295-305.

Dankers, Norbert, Binsbergen, Michel, Zegers, Koos, Laane, Remi, and van der Loeff, M.R., 1984, Transportation of water, particulate and dissolved organic and inorganic matter between a salt marsh and the Ems- Dollard estuary, The Netherlands: Estuarine Coastal Shelf Science, v. 19, p. 143-165.

Davies, B.E., 1974, Loss-on-ignition as an estimate of soil organic matter: Soil Science Society of America Proceedings, v. 38, p. 150-151.

Doering, P.H., Roman, C.T., Beatty, L.L., Keller, A.A., and Oviatt, C.A., 1995, Water quality and habitat evaluation of Bass Harbor Marsh, Acadia National Park, Maine: National Park Service Technical Report NPS/NESORNR/NRTR/95-31, 147p.

Farris, C.N., and Oviatt, C.A., 1999, Changes in metabolic rates under fluctuating salinity regimes for two subtidal estuarine habitats: Estuaries, v. 22, p. 126-137.

Fuller, C.C., vanGeen, Alexander, Baskaran, Mark, and Anima, Roberto, 1999, Sediment chronology in San Francisco Bay defined by ${ }^{210} \mathrm{~Pb},{ }^{234} \mathrm{Th},{ }^{137} \mathrm{Cs}$, and ${ }^{239,240} \mathrm{Pu}$ : Marine Chemistry, v. 64, p. 7-27.

Gesch, D.B., Gutierrez, B.T., and Gill, S.K., 2009, Coastal elevations, chap. 2 in Titus, J.G., coordinator, Coastal sensitivity to sea level rise-A focus on the mid-Atlantic region-A report by the U.S. Climate Change Science Program and the Subcommittee on Global Change Research: Washington, D.C., U.S. Environmental Protection Agency, p. 25-42.

Glibert, P.M., Boyer, J.M., Heil, C.A., Madden, C.J., Sturgis, Brian, and Wazniak, C.E., 2010, Blooms in lagoons different from those of river-dominated estuaries, in Kennish, M.J., and Pearl, H.W., eds., Coastal Lagoons-Critical Habitats of Environmental Change: Boca Raton, Florida, CRC Press, p. 91-113.

Glibert, P. M., Kelly, Vincent, Alexander, Jeffrey, Codispoti, L.A., Boicourt, W.C., Trice, T.M., and Michael, Bruce, 2008, In situ nutrient monitoring-A tool for capturing nutrient variability and the antecedent conditions that support algal blooms: Harmful Algae, v. 8, p. 175-181. 
Hannouche, Ali, GHassan, Chebbo, Ruban, Gwenaël, Tassin, Bruno, Lemaire, B.J., and Joannis, Claude, 2011, Relationship between turbidity and total suspended solids concentration within a combined sewer system: Water Science and Technology, v. 64, no. 12, p. 2245-2252.

Hargis, T.G., and Twilley, R.R., 1994, Improved coring device for measuring soil bulk density in a Louisiana deltaic marsh: Journal of Sedimentary Research, Section A: Sedimentary Petrology and Processes, v. 64, p. 681-683.

Hayhoe, Katharine, Wake, C.P., Huntington, T.G., Luo, Lifeng, Schwartz, M.D., Sheffield, Justin, Wood, E.F., Anderson, Bruce, Bradbury, J.A., DeGaetano, A.T., and Wolfe, David, 2007, Past and future changes in climate and hydrological indicators in the U.S. Northeast: Climate Dynamics, v. 28, p. 381-407.

Hirsch, R.M., 1982, A comparison of four streamflow record extension techniques: Water Resources Research, v. 18, p. 1081-1088.

Howarth, R.W., 2008, Coastal nitrogen pollution-A review of sources and trends globally and regionally: Harmful Algae, v. 8, p. 14-20.

Howarth, R.W., Swaney, D.P., Boyer, E.W., Marino, Roxanne, Jaworski, N.A., and Goodale, C.L., 2006, The influence of climate on average nitrogen export from large watersheds in the Northeastern United States: Biogeochemistry, v. 79, p. 163-186.

Huntington, T.G., 2006, Evidence for intensification of the global water cycle-Review and synthesis: Journal of Hydrology, v. 319, p. 83-95.

Huntington, T.G., Culbertson, C.W., and Duff, J.H., 2012, Ambient and potential denitrification rates in marsh soils of Northeast Creek and Bass Harbor Marsh watersheds, Mount Desert Island, Maine: U.S. Geological Survey Scientific Investigations Report 2012-5166, 40 p. (Also available at http://pubs.usgs.gov/sir/2012/5166/.)

Huntington, T.G., Richardson, A.D., McGuire, K.J., and Hayhoe, Katharine, 2009, Climate and hydrological changes in the northeastern United States-Recent trends and implications for forested and aquatic ecosystems: Canadian Journal of Forest Research, v. 39, p. 199-212.

Ji, Rubaro, Davis, C.S., Chen, Changsheng, Townsend, D.W., Mountain, D.G., and Beardsley, R.C., 2007, Influence of ocean freshening on shelf phytoplankton dynamics: Geophysical Research Letters, v. 34, L24607, http://dx.doi.org/10.1029/2007GL032010.

Kahl, J.S., Manski, David, Flora, Mark, and Houtman, Nick, eds., 2000, Water Resources Management Plan: Acadia National Park, Mount Desert Island, Maine [variously paginated]. Karl, D.M., Michaels, A.F., Bergman, Britta, Capone, D.G., Carpenter, E.J., Letelier, Ricardo, Lipschultz, Fredric, Paerl, H.W., Sigman, D.M., and Stal, L., 2002, Dinitrogen fixation in the world's oceans: Biogeochemistry, v. 57-58, p. 47-98.

Kearney, M.S., Grace, R.E., and Stevenson, J.C., 1988, Marsh loss in Nanticoke estuary, Chesapeake Bay: The Geographical Review, v. 78, p. 205-220.

Kinney, E.H., and Roman, C.T., 1998, Response of primary producers to nutrient enrichment in a shallow estuary: Marine Ecology Progress Series, v. 163, p. 89-98.

Lane, S.L., Flanagan, Sarah, and Wilde, F.D., 2003, Selection of equipment for water sampling (ver. 2.0): U.S. Geological Survey Techniques of Water-Resources Investigations, book 9, chap. A2, accessed December 17, 2013 at http://pubs.water.usgs.gov/twri9A2/.

Levesque, V.A., and Oberg, K.A., 2012, Computing discharge using the index velocity method: U.S. Geological Survey Techniques and Methods 3-A23, 148 p. (Also available at http://pubs.usgs.gov/tm/3a23/.)

Lucas, L.V., and Cloern, J.E., 2002, Effects of tidal shallowing and deepening on phytoplankton production dynamics - A modeling study: Estuaries and Coasts, v. 25, p. 497-507. 
Mitchell, B.R., Shriver, G.W., Dieffenbach, Fred, Moore, T., Faber-Langendoen, Don, Tierney, G.L., Lombard, P.J., and Gibbs, J.P., 2006, Northeast Temperate Network Vital Signs Monitoring Plan: Woodstock, Vt., National Park Service, Northeast Temperate Network Technical Report NPS/NER/NRTR-2006/059, 131 p.

Morris, J.T., 1991, Effects of nitrogen loading on wetland ecosystems with particular reference to atmospheric deposition: Annual Review of Ecology and Systematics, v. 22, p. 257-279.

National Atmospheric Deposition Program, 2012, Daily precipitation data for Acadia National Park, Mount Desert Island, Maine: National Atmospheric Deposition Program database, accessed May 7, 2013, at http://nadp.sws.uiuc.edu.

National Oceanic and Atmospheric Administration, 2013, Sea level trends data for Bar Harbor, Maine: National Oceanic and Atmospheric Administration database, accessed May 7, 2013, at http://www.tidesandcurrents.noaa.gov/sltrends.

National Oceanic and Atmospheric Administration, 2012, Tidal data for Frenchman's Bay, Bar Harbor, Maine: National Oceanic and Atmospheric Administration database, accessed December 20, 2012, at http://tidesandcurrents.noaa.gov.

National Research Council, 2000, Clean coastal waters-Understanding and reducing the effects of nutrient pollution: Washington, D.C., National Academies Press.

Neckles, H.A., Kopp, B.S., Nielsen, M.G., and Guntenspergen, G.R., 2003, Autotrophic responses to nutrient loadings in a Ruppia dominated estuary-current status and future projections: Biennial Meeting of the Estuarine Research Federation, September 14-18, 2003, Seattle, Wash.

Nicholls, R.J., Wong, P.P., Burkett, V.E. Codignotto, J.O., Hay, J.E., McLean, R.F., Ragoonaden, Sachooda, and Woodroffe, C.D., 2007, Coastal systems and low-lying areas, in Parry, M.L., Canziani, O.F., Palutikof, P.J. van der Linden, and Hanson, C.E., eds., Climate Change 2007-Impacts, Adaptation and Vulnerability. Contribution of Working Group II to the Fourth Assessment Report of the Intergovernmental Panel on Climate Change: Cambridge, United Kingdom, Cambridge University Press, p. 315-356.

Nielsen, M.G., 2002, Water budget for and nitrogen loads to Northeast Creek, Bar Harbor, Maine: U.S. Geological Survey Water-Resources Investigations Report 02-4000, 32 p.

Nielsen, M.G., and Dudley, R.W., 2013, Estimates of future inundation of salt marshes in response to sea-level rise in and around Acadia National Park, Maine: U.S. Geological Survey Scientific Investigations Report 2012-5290, 20 p. (Also available at http://pubs.usgs.gov/sir/2012/5290/.)

Nielsen, M.G., and Kahl, J.S., 2007, Nutrient export from watersheds on Mt. Desert Island, Maine, as a function of land use and fire history: Environmental Monitoring and Assessment, v. 126, p. 81-96.

Nixon, S.W., 1980, Between coastal marshes and coastal waters-A review of twenty years of speculation and research on the role of salt marshes in estuarine productivity and water chemistry, University of Rhode Island, Marine Advisory Service, Publications Unit, 89 p.

Nixon, S.W., 1995, Coastal marine eutrophication - a definition, social causes, and future concerns: Ophelia, v. 41, p. 199-219.

O’Dell, J.W., 1993, Method 350.1—Determination of ammonia nitrogen by semi-automated colorimetry (Revision 2.0): Cincinnati, Ohio, U.S. Environmental Protection Agency, Environmental Monitoring Systems Laboratory, Office of Research and Development, 15 p.

Parris, Adam, Bromirski, Peter, Burkett, Virginia, Cayan, Dan, Culver, Mary, Hall, John, Horton, Radley, Knuuti, Kevin, Moss, Richard, Obeysekera, Jayantha, Sallenger, Abby, and 
Weiss, Jeremy, 2012, Global sea level rise scenarios for the United States National Climate Assessment: NOAA Technical Memorandum OAR CPO-1, 37 pp.

Patterson, W.A., III, Saunders, K.E., and Horton, L.J., 1983, Fire regimes of the coastal Maine forests of Acadia National Park: Boston, Mass., National Park Service, Office of Scientific Programs Report OSS 83-3, 259 p.

Pettigrew, N.R., Townsend, D.W., Xue, H., Wallinga, J.P., Brickley, P.J., and Hetland, R.D., 1998, Observations of the eastern Maine coastal current and its offshore extensions in 1994: Journal of Geophysical Research, v. 103, p. 30623-30639.

Rozema, Jelte, Leendertse, Peter, Bakker, Jan, and van Wijnen, Harm, 2000, Nitrogen and vegetation dynamics in European salt marshes, in Weinstein, M.P., and Kreeger, D.A., eds., Concepts and controversies in tidal marsh ecology: Dordrecht, Kluwer Academic Publishing, p. 469-494.

Runkel, R.L., Crawford, C.G., and Cohn, T.A., 2004, Load estimator (LOADEST)-A FORTRAN program for estimating constituent loads in streams and rivers: U.S. Geological Survey Techniques and Methods, book 4, chap. A5, 69 pp.

Sallenger, A.H., Doran, K.S., and Howd, P.A., 2012, Hotspot of accelerated sea-level rise on the Atlantic coast of North America: Nature Climate Change, v. 2, p. 884-888.

Sowles, John, 2001, Nitrogen in the Gulf of Maine-Sources, susceptibility, and trends: A Workshop on Nutrient Management in the Gulf of Maine, Portsmouth, N.H., November 2829, 2001, white paper 1, $16 \mathrm{p}$.

Tiner, R.W., and Bergquist, H.C., 2003, Historical analysis of wetlands and their functions for the Nanticoke River watershed-A comparison between pre-settlement and 1998 conditions: Hadley, Mass., U.S. Fish and Wildlife Service, National Wetlands Inventory (NWI) Program, Northeast Region, NWI technical report, $41 \mathrm{p}$.

Tobias, C.R., and Neubauer, S.C., 2009, Salt marsh biogeochemistry-An overview, in Perillo, G. M. E,, Wolanski, Eric, Cahoon, D. R., and Brinson, M. M., eds., Coastal wetlands-An integrated ecosystem approach: Philadelphia, Pennsylvania, Elsevier, p. 445-492

Townsend, D.W., 1998., Sources and cycling of nitrogen in the Gulf of Maine: Journal of Marine Systems, v. 16, p. 283-295.

Townsend, D.W., Pettigrew, N.R., and Thomas, A.C., 2001, Offshore blooms of the red tide dinoflagellate, Alexandrium sp., in the Gulf of Maine: Continental Shelf Research, v. 21, p. 347-369.

Turnipseed, D.P., and Sauer,V.B., 2010, Discharge measurements at gaging stations: U.S. Geological Survey Techniques and Methods book 3, chap. A8, 87 p. (Also available at http://pubs.usgs.gov/tm/tm3-a8/.)

U.S. Environmental Protection Agency, 1979a, Method No. 350.1 in Methods for chemical analysis of water and wastes: Cincinnati, Ohio, U.S. Environmental Protection Agency, Office of Research and Development, Report No. EPA-600/7-79-20, 460 p. (Revised 1983.)

U.S. Environmental Protection Agency, 1979b, Method No. 353.2 in Methods for chemical analysis of water and wastes: Cincinnati, Ohio, U.S. Environmental Protection Agency, Office of Research and Development, Report No. EPA-600/7-79-20, 460 p. (Revised 1983.)

U.S. Environmental Protection Agency, 1979c, Method No. 365.1 in Methods for chemical analysis of water and wastes: Cincinnati, Ohio, U.S. Environmental Protection Agency, Office of Research and Development, Report No. EPA-600/7-79-20, 460 p. (Revised 1983.)

U.S. Environmental Protection Agency, 2001, National Coastal Condition Report: Washington, D.C., Office of Research and Development and Office of Water, EPA-620/R-01/005. 
U.S. Geological Survey, 2013a, Acadia National Park nutrient load and estuarine response decision support system: U.S. Geological Survey, Upper Midwest Environmental Sciences Center, accessed on March 27, 2013, at http://www.umesc.usgs.gov/management/dss/anp_nutrient.html.

U.S. Geological Survey, 2013b, Stream-water discharge records for Otter Creek near Bar Harbor, Maine (USGS streamgaging station 01022840): U.S. Geological Survey National Water Information System, accessed on March 27, 2013, at http://waterdata.usgs.gov/me/nwis.

Valderrama, J.C., 1981, The simultaneous analysis of total nitrogen and total phosphorous in natural waters: Marine Chemistry, v. 10, p. 109-122.

Valiela, Ivan, Foreman, Kenneth, LaMontagne, Michael, Hersh, Douglas, Costa, Joseph, Peckol, Paulete, DeMeo-Andreson, Barbara, D’Avanzo, Charlene, Babione, Michele, Sham, CChi-Ho, Brawley, John, and Lajtha, Kate, 1992, Couplings of watersheds and coastal waters-Sources and consequences of nutrient enrichment in Waquoit Bay, Massachusetts: Estuaries, v. 15, p. 443-457.

Van Metre, P.C., Wilson, J.T., Fuller, C.C., Callender, Edward, and Mahler, B.J., 2004, Collection, analysis, and age dating of sediment cores from 56 U.S. lakes and reservoirs sampled by the U.S. Geological Survey, 1992-2001: U.S. Geological Survey Scientific Investigations Report 2004-5184, $180 \mathrm{p}$.

Vitousek, P.M., Aber, J.D., Howarth, R.W., Likens, G.E., Matson, P.A., Schindler, D.W., Schlesinger, W.H., and Tilman, D.G., 1997, Human alteration of the global nitrogen cycleSources and consequences: Ecological Applications, v. 7, p. 737-750.

Wagner, R.J., Boulger, R.W., Jr., Oblinger, C.J., and Smith, B.A., 2006, Guidelines and standard procedures for continuous water-quality monitors - Station operation, record computation, and data reporting: U.S. Geological Survey Techniques and Methods 1-D3, 51 p., accessed April 10, 2006, at http://pubs.water.usgs.gov/tm1d3.

Whiting, G.J., McKellar, H.N., Spurrier, J.D., and Wolaver, T.G., 1989, Nitrogen exchange between a portion of vegetated salt marsh and the adjoining creek: Limnology and Oceanography, v. 34, p. 463-473.

Wolaver, T.G., Dame, R.F., Spurrier, J.D., and Miller, A.B., 1988, Sediment exchange between a euhaline salt marsh in South Carolina and the adjacent tidal creek: Journal of Coastal Research, v. 4, p. 17-26.

Wood, E.D., Armstrong, F.A.J., and Richards, F.A., 1967, Determination of nitrate in sea water by cadmium-copper reduction to nitrite: Journal of the Marine Biological Association of the United Kingdom, v. 47, p. 23-31. 


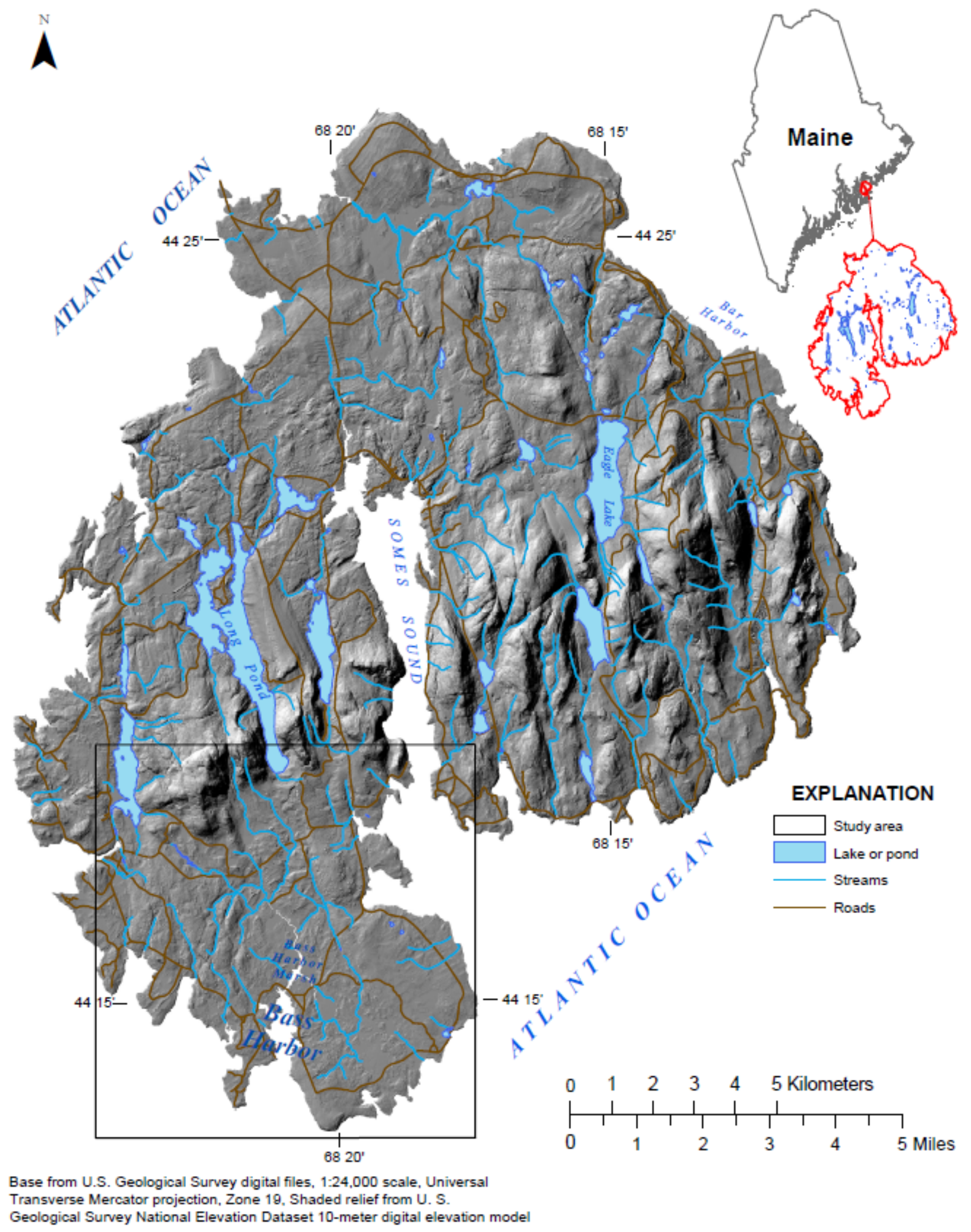

Figure 1. Map showing Mount Desert Island, Maine, in shaded relief, including the general location of Bass Harbor Marsh as an inset. 


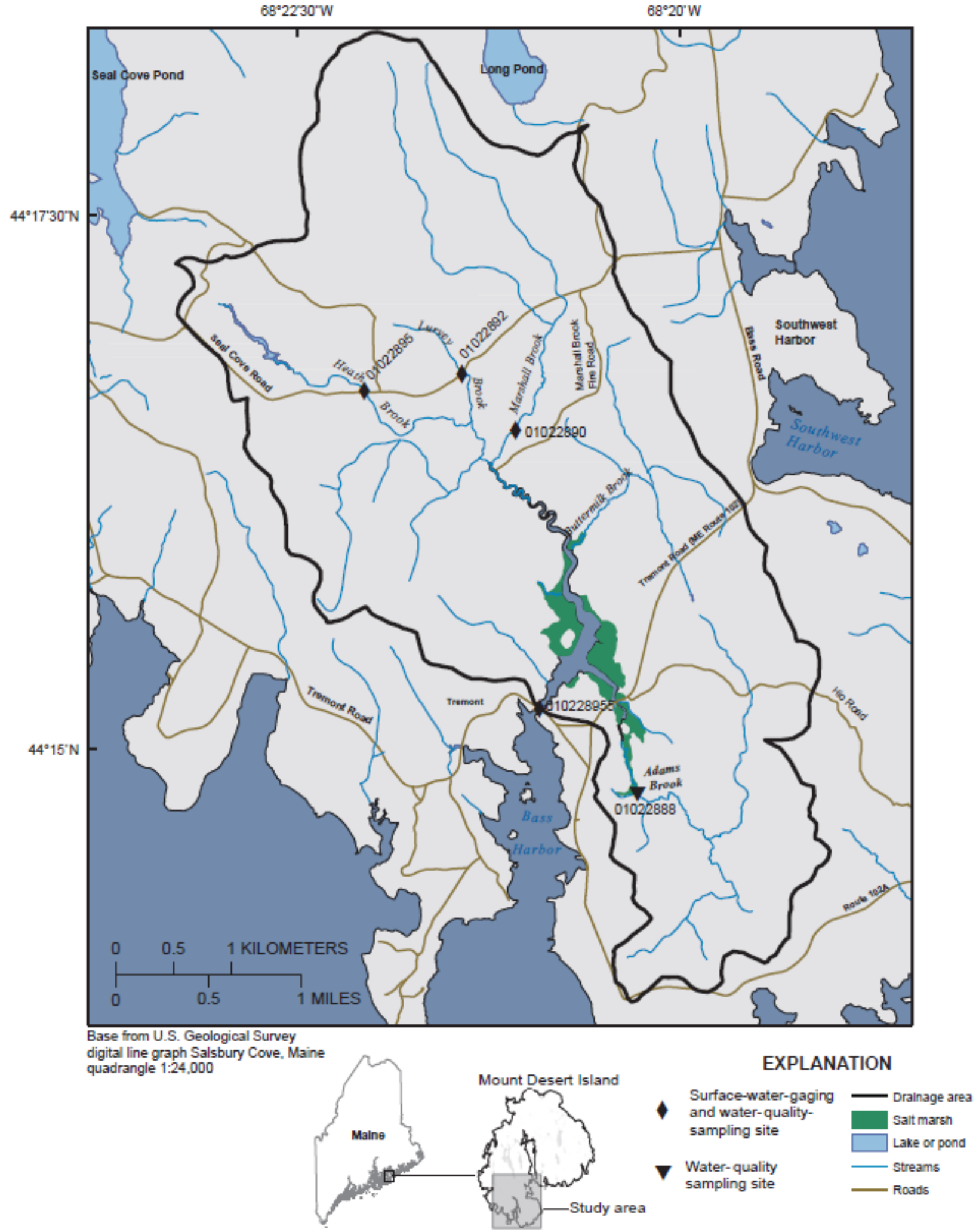

Figure 2. Map showing of Bass Harbor Marsh watershed, including watershed outline, streams, roads, Bass Harbor Marsh, and sampling locations, Mount Desert Island, Maine. 


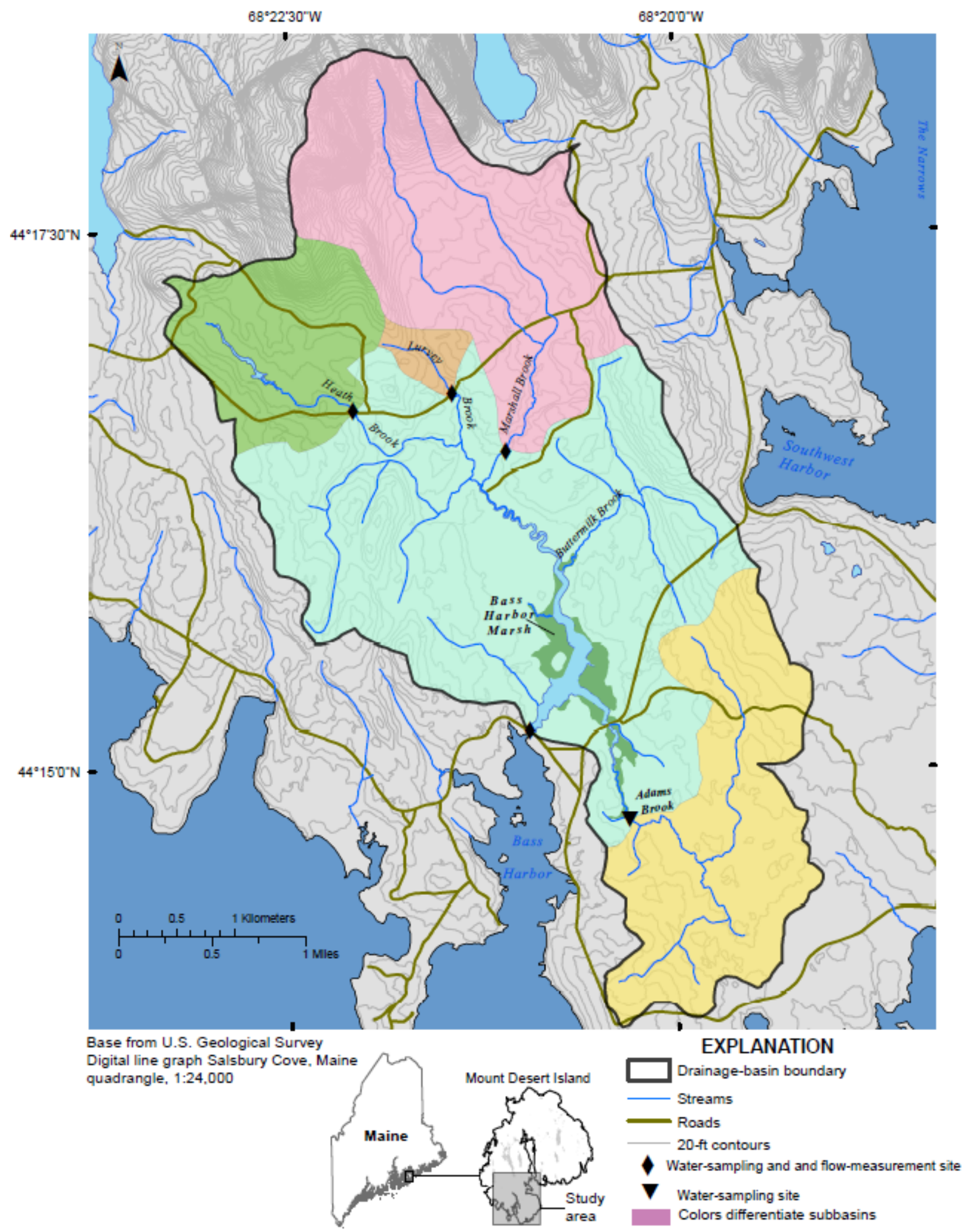

Figure 3. Map showing subwatersheds and tributaries delineated at sampling stations, Bass Harbor Marsh watershed, Mount Desert Island, Maine. 


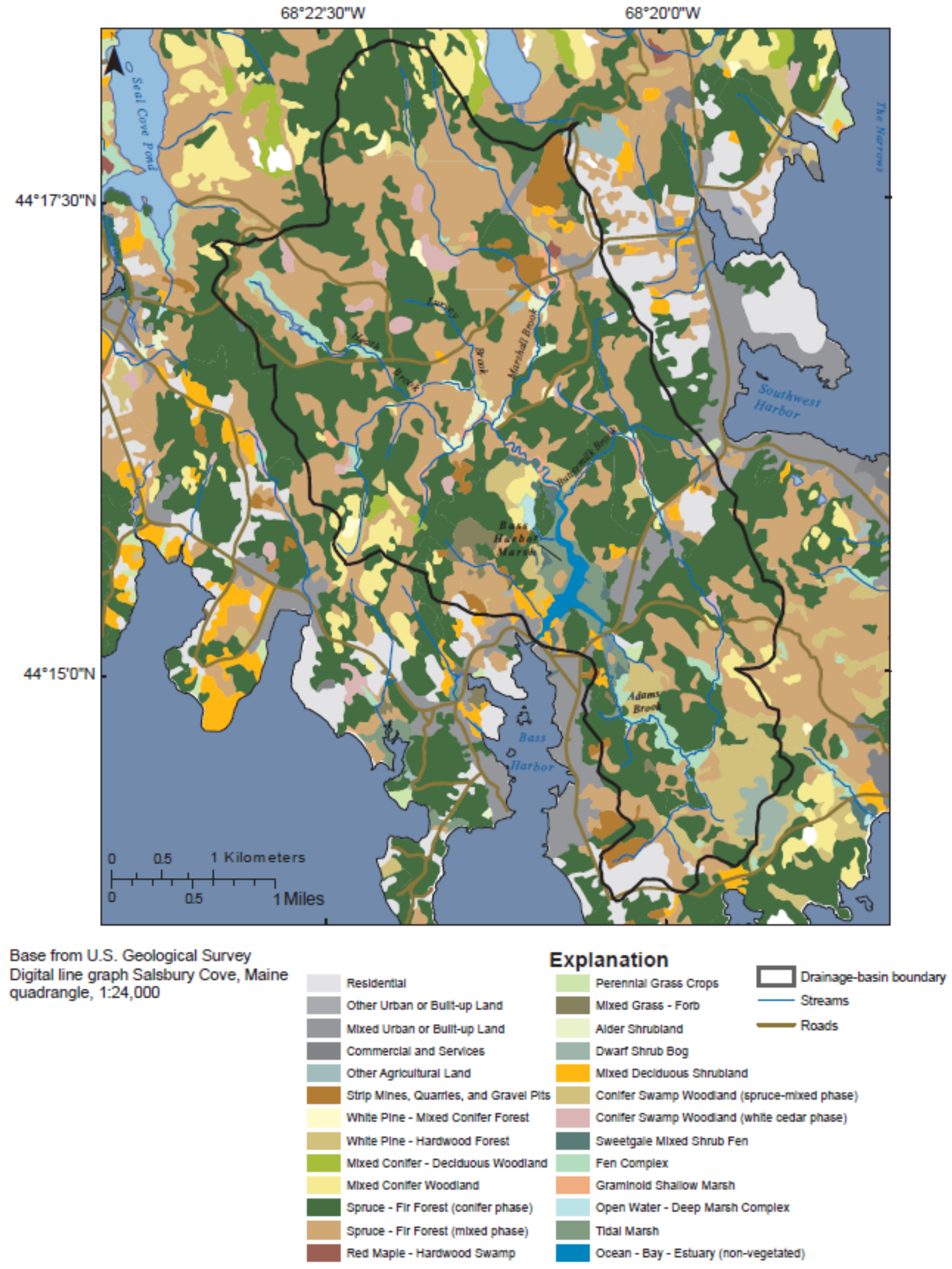

Figure 4. Map showing major vegetation types, streams, and roads at Bass Harbor Marsh watershed, Mount Desert Island, Maine. 


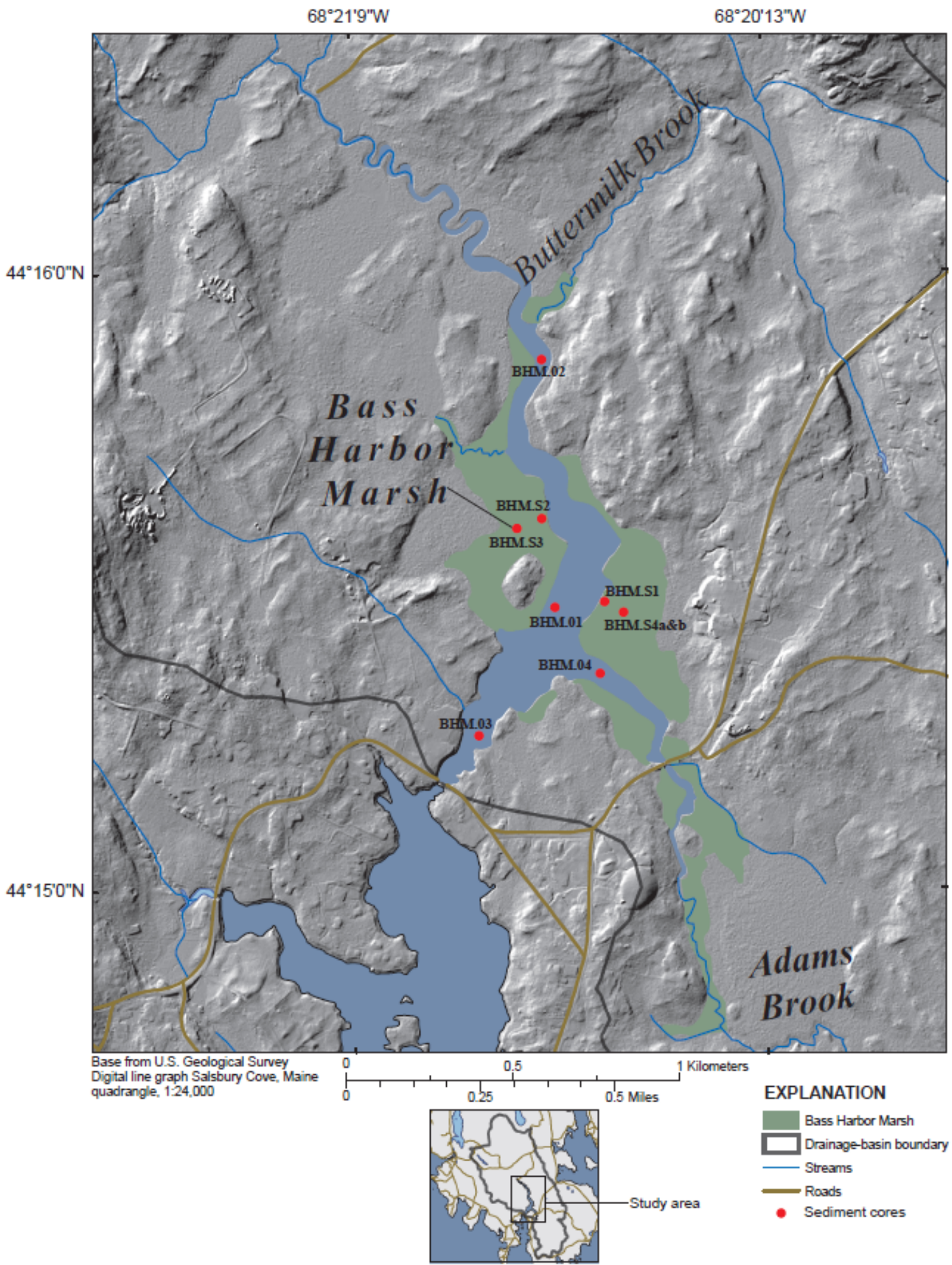

Figure 5. Map showing Bass Harbor Marsh estuary, fringing marsh, and surrounding area in shaded relief, Mount Desert Island, Maine. Locations where sediment cores were collected in 2009 and 2011 are also shown. 

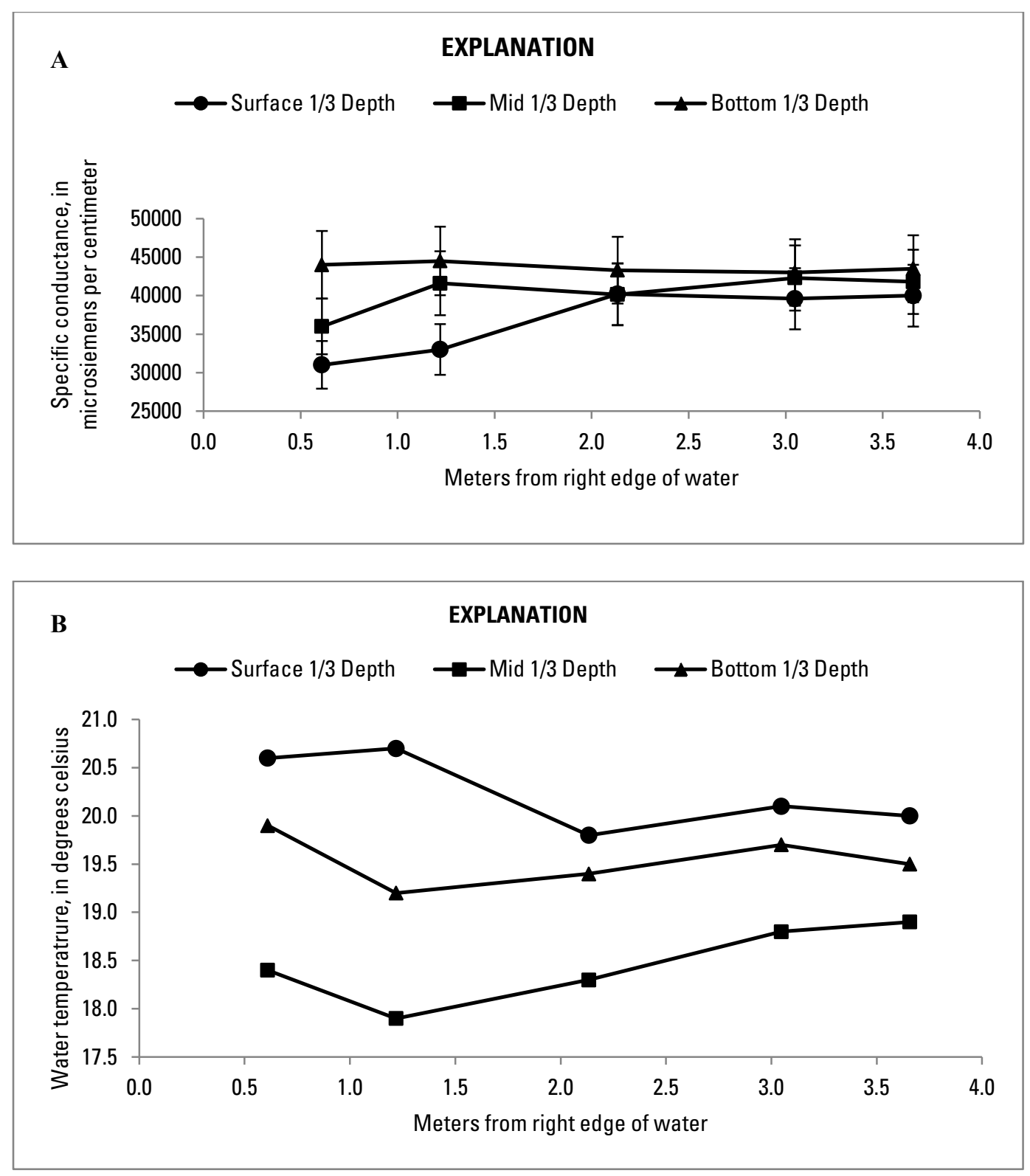

Figure 6. Graphs showing A, specific conductance and B, water temperature recorded during an ebb tide at 10:15 on June 21, 2012, at Bass Harbor Marsh estuary outlet, Mount Desert Island, Maine. Measurements were recorded in the middle of three depth strata: the surface, middle, and bottom depth intervals. Error bars indicate the variability of the measurements that was observed over about 1 minute. The actual variability was not recorded but was estimated to be about \pm 10 percent of the value shown. 


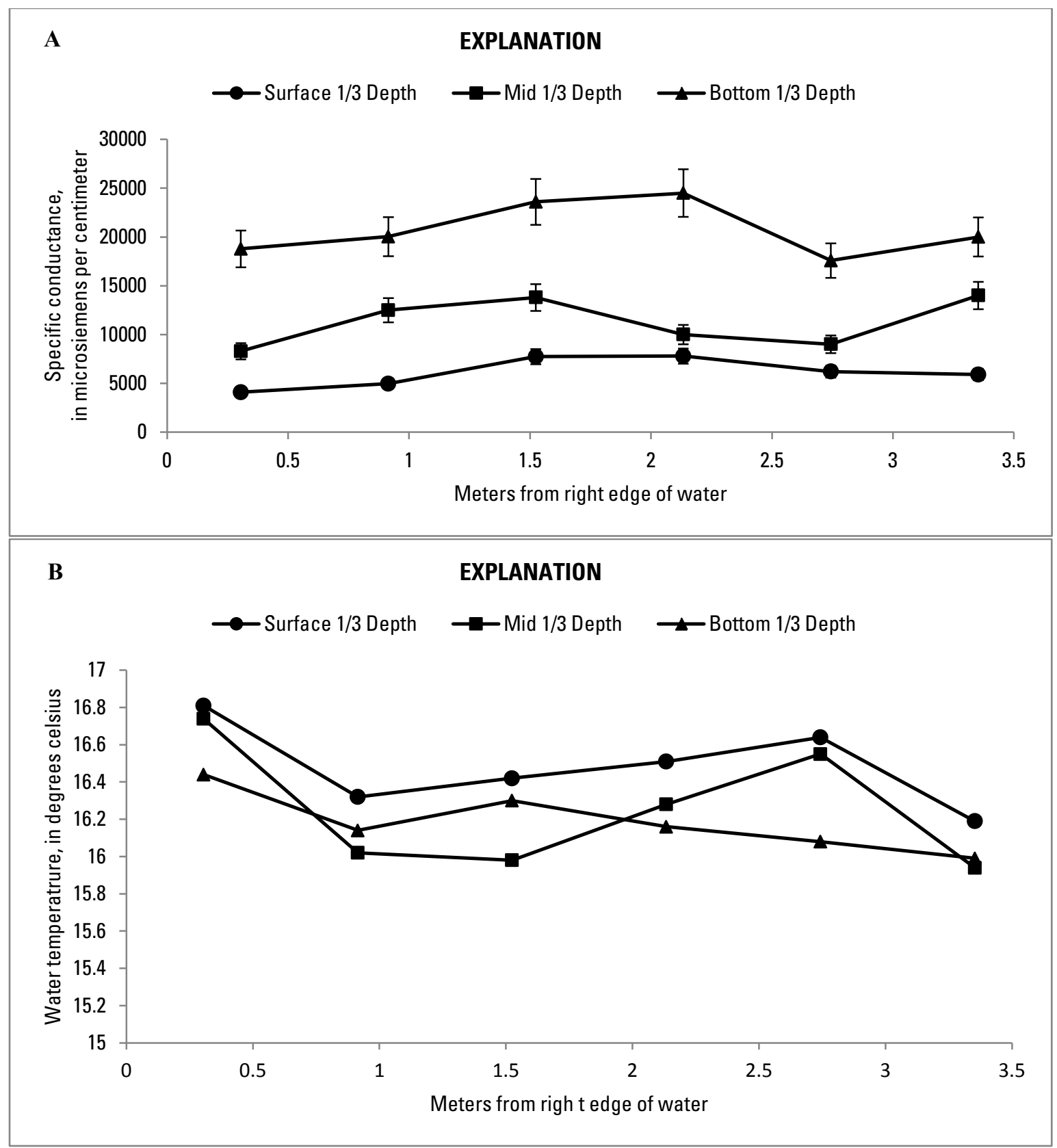

Figure 7. Graphs showing recordings taken on at ebb tide at 11:00 on October 3, 2012, at Bass Harbor Marsh estuary outlet, Mount Desert Island, Maine, of $A$, specific conductance, $B$, water temperature, and $C$, turbidity, and on a flood tide recorded at 14:15 on October 3, 2012, of $D$, specific conductance, $E$, water temperature, and $F$, turbidity. Measurements were recorded in the middle of three depth strata: the surface, middle and bottom depth intervals. Error bars indicate the variability of the measurements that was observed over about 1 minute. The actual variability was not recorded but was estimated to be about \pm 10 percent of the value shown. 


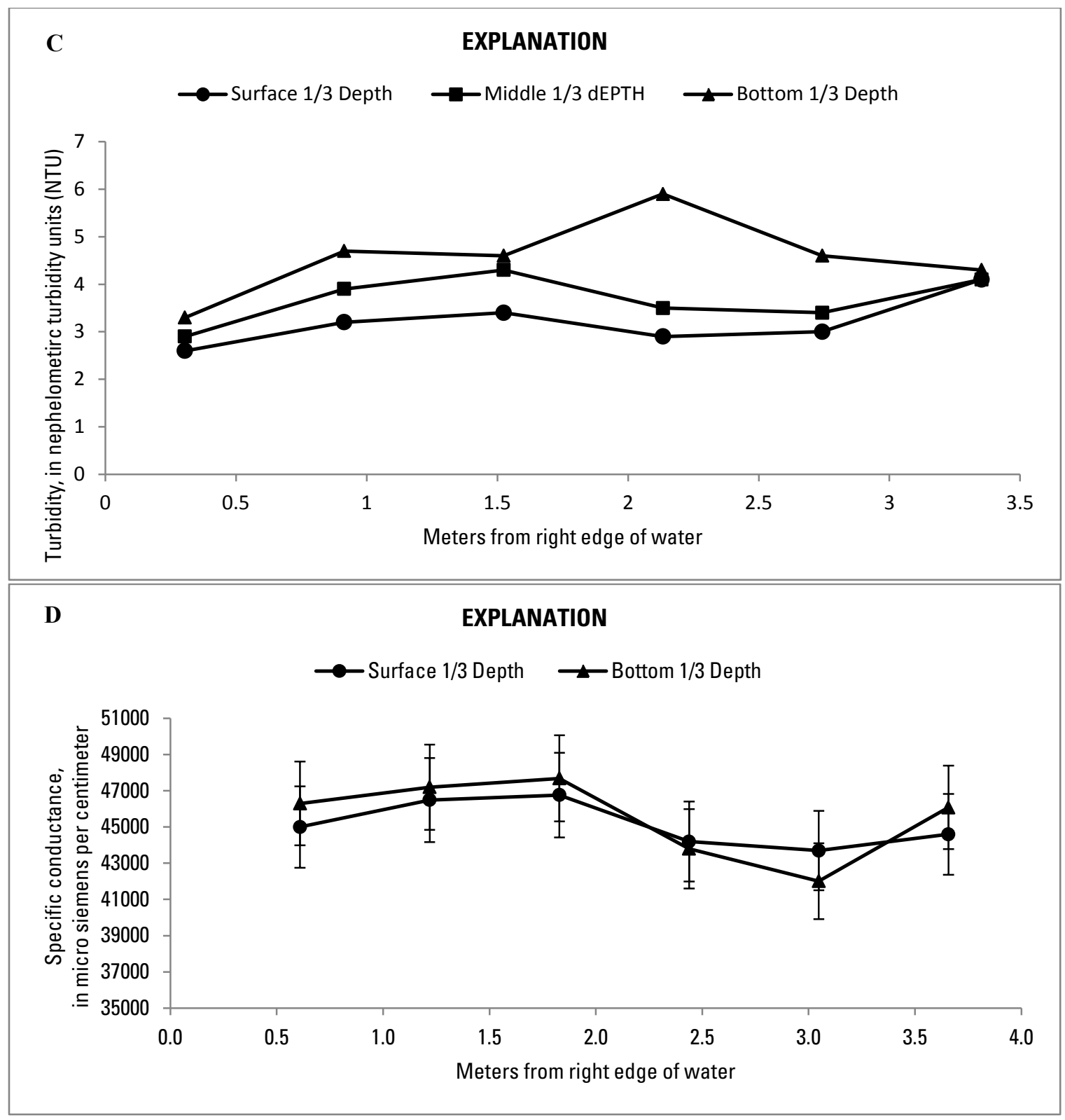

Figure 7. Graphs showing recordings taken on at ebb tide at 11:00 on October 3, 2012, at Bass Harbor Marsh estuary outlet, Mount Desert Island, Maine, of $A$, specific conductance, $B$, water temperature, and $C$, turbidity, and on a flood tide recorded at 14:15 on October 3,2012, of $D$, specific conductance, $E$, water temperature, and $F$, turbidity. Measurements were recorded in the middle of three depth strata: the surface, middle and bottom depth intervals. Error bars indicate the variability of the measurements that was observed over about 1 minute. The actual variability was not recorded but was estimated to be about \pm 10 percent of the value shown.-Continued 


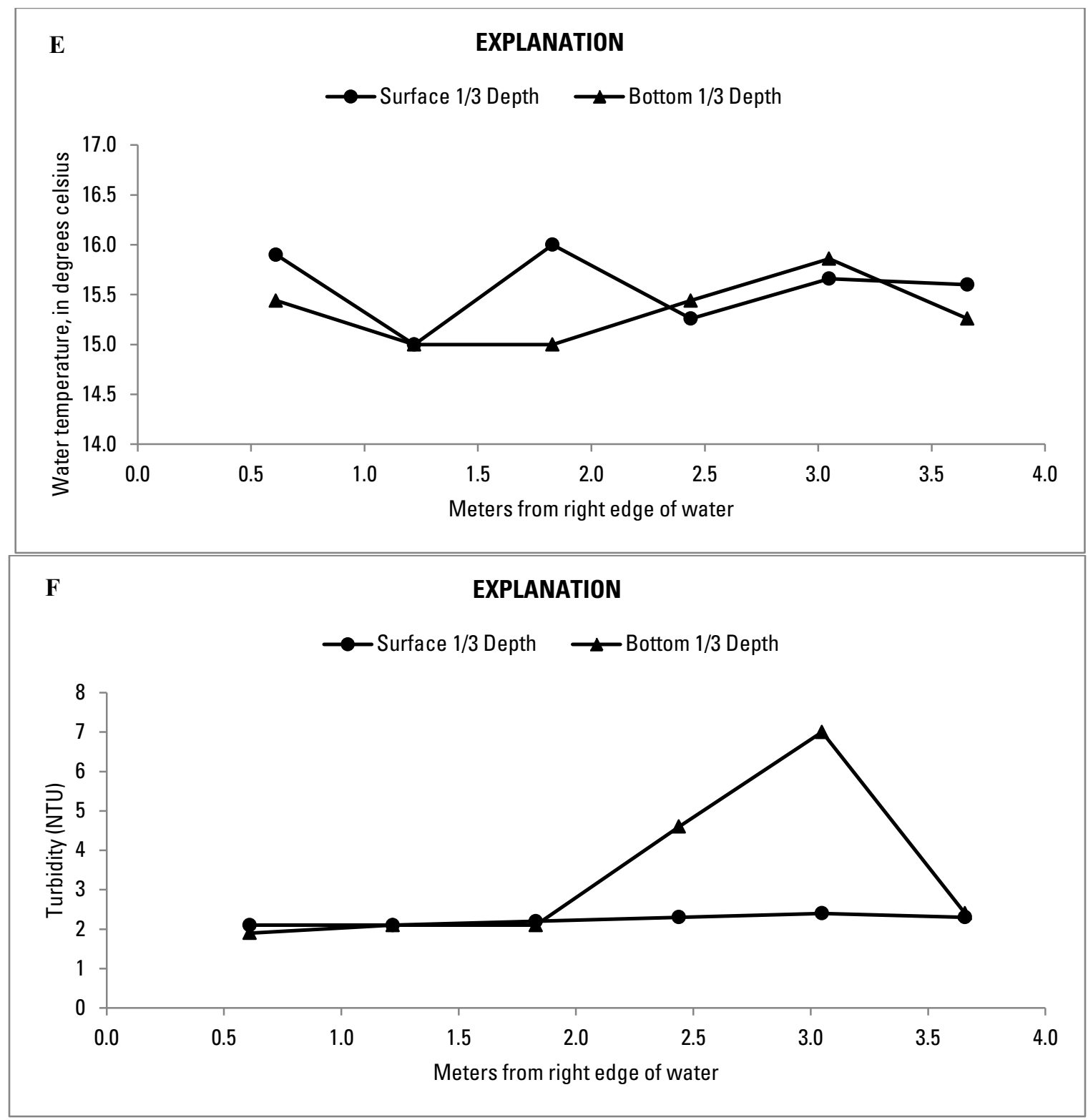

Figure 7. Graphs showing recordings taken on at ebb tide at 11:00 on October 3, 2012, at Bass Harbor Marsh estuary outlet, Mount Desert Island, Maine, of $A$, specific conductance, $B$, water temperature, and $C$, turbidity, and on a flood tide recorded at 14:15 on October 3,2012 , of $D$, specific conductance, $E$, water temperature, and $F$, turbidity. Measurements were recorded in the middle of three depth strata: the surface, middle and bottom depth intervals. Error bars indicate the variability of the measurements that was observed over about 1 minute. The actual variability was not recorded but was estimated to be about \pm 10 percent of the value shown.-Continued 


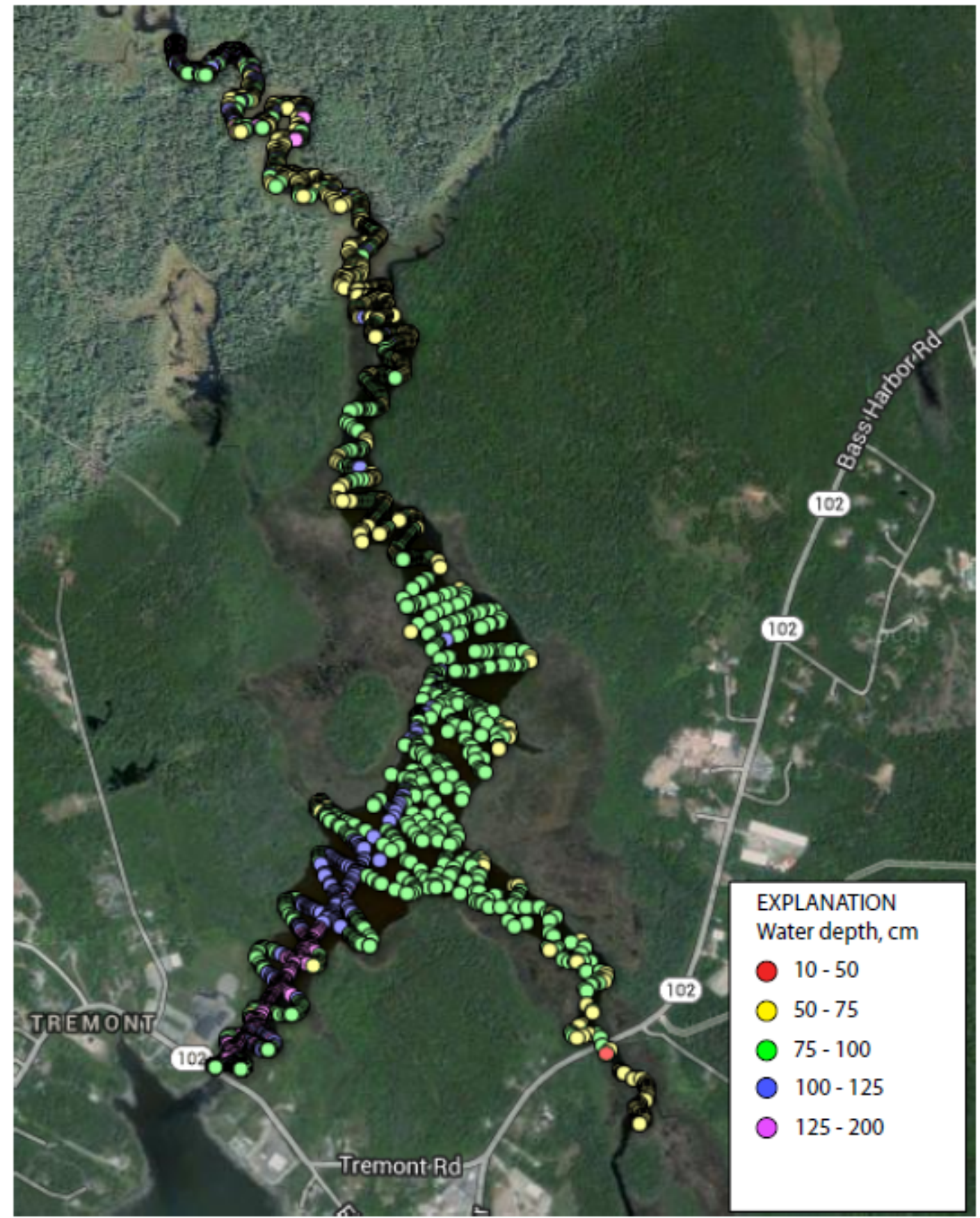

Base image credit: Maine Coastal Low Tide Ortho-rectified Digital Images, 2008. Maine Office of Geographic Information Systems (MEGIS).

Figure 8. Map showing the track of the acoustic Doppler current profiler/Global Positioning System (ADCP/GPS) that was towed in the Bass Harbor Marsh estuary, Mount Desert Island, Maine, on July 5, 2012. The track is color-coded showing the depth of water in the estuary at 14:01 at each point. 


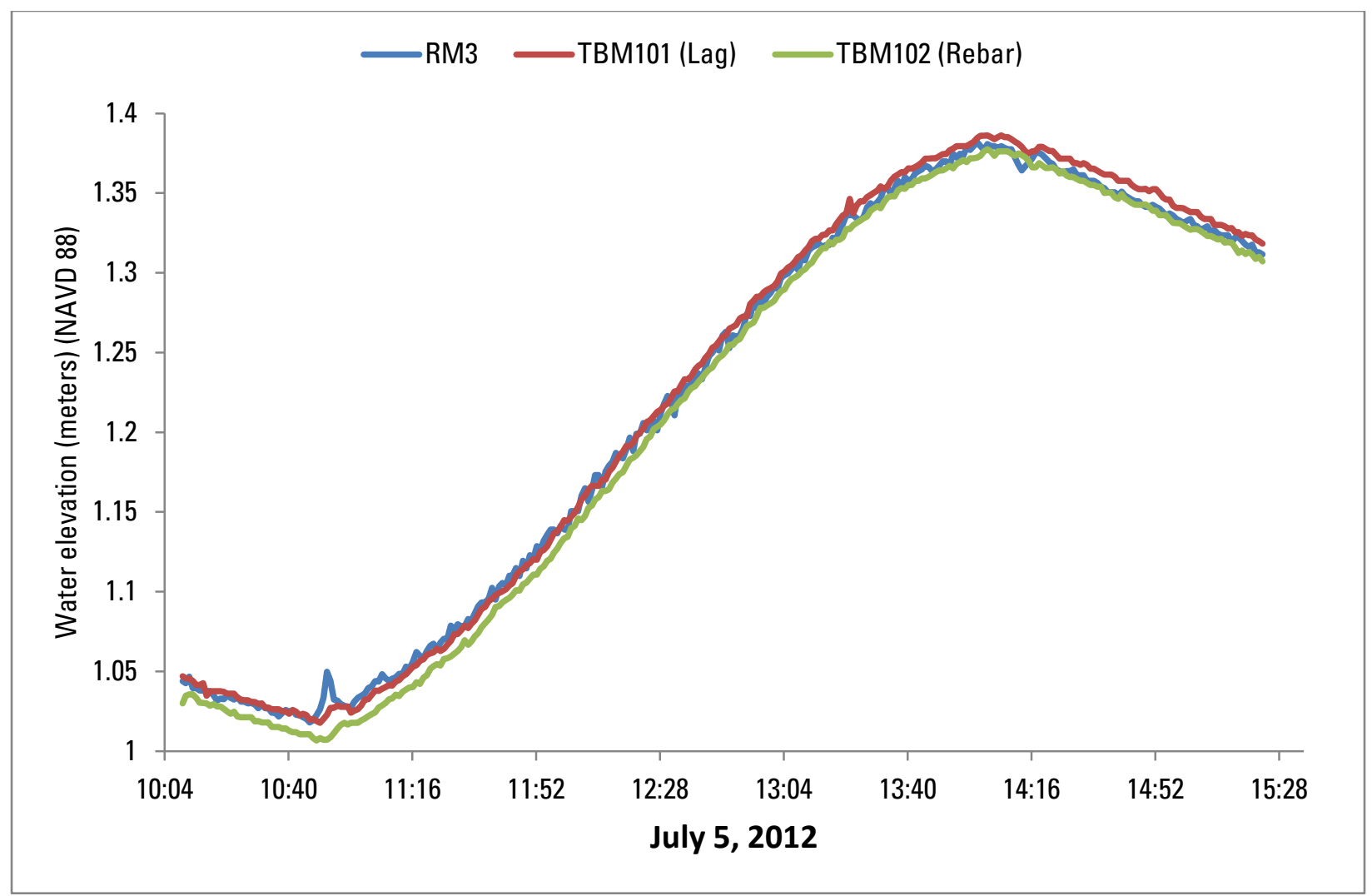

Figure 9. Graph showing water elevation (in reference to the North American Vertical Datum of 1988 (NAVD 88)) at the three reference points used to establish the slope of the water surface during the bathymetric survey, Bass Harbor Marsh estuary, Mount Desert Island, Maine. RM3, TBM101, and TBM102 are vertical reference control points in the Bass Harbor Marsh estuary. RM3 is a lagbolt in a bolder near the estuary outlet, TBM101 is a lagbolt $310.9 \mathrm{~m}$ upstream of the estuary outlet and TBM102 is vertically-set rebar $592.2 \mathrm{~m}$ upstream of the estuary outlet. 


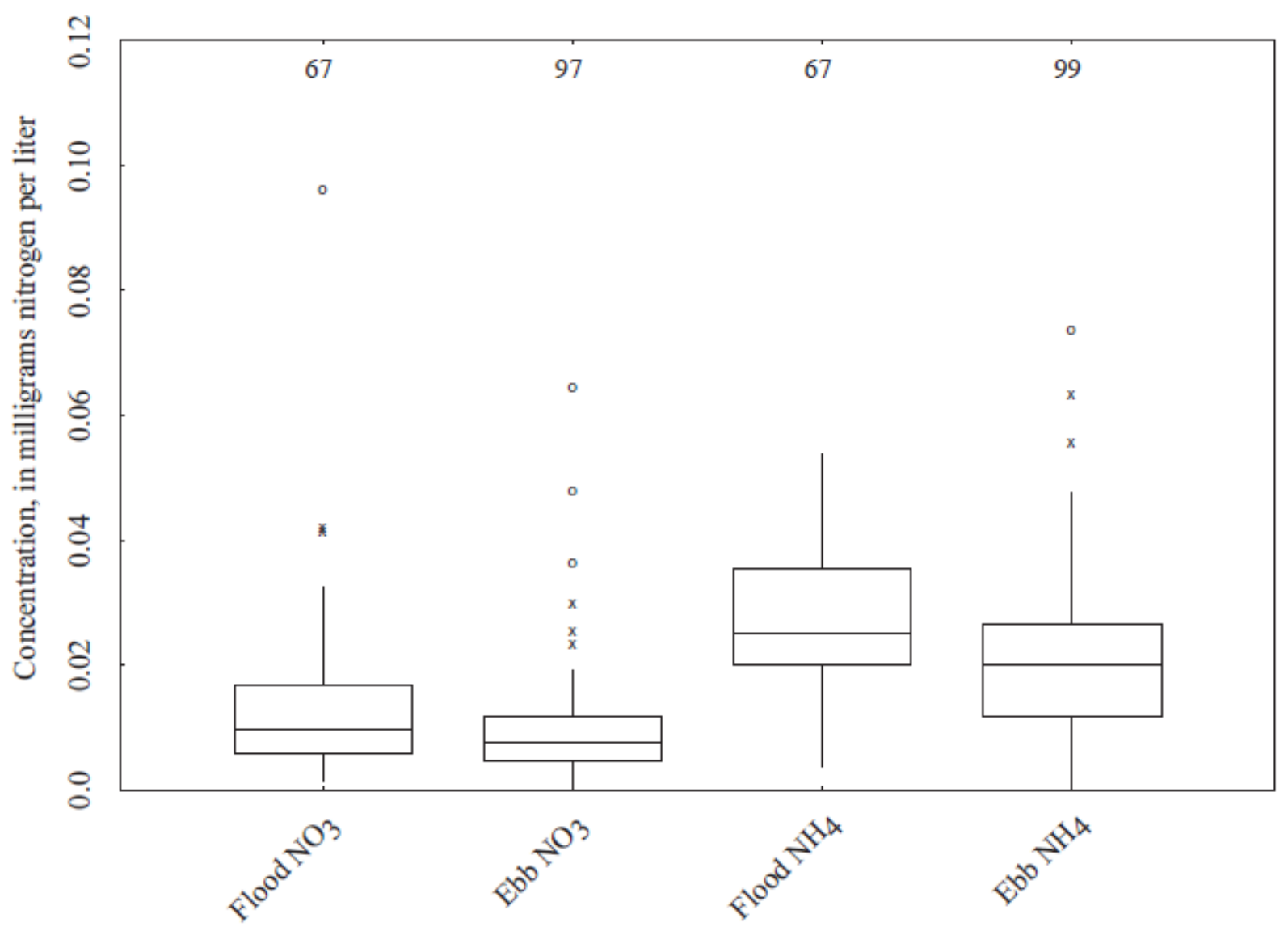

Figure 10. Graph showing concentrations of nitrate and ammonium in flood and ebb tides at the Bass Harbor Marsh estuary outlet, Mount Desert Island, Maine, during 2011 and 2012. Box and whisker plots show median, 25th and 75th quartiles. Whiskers show the last observation within $1.5 \mathrm{x}$ the interquartile range (IQR, distance between the 25th and 75th quartiles). The "x" symbol indicates observations between 1.5 and 3.0 times the IQR and the "o" symbol indicates observations greater than 3 times the IQR. Numbers at the top of the graph are the total number of samples analyzed for the indicated constituent in flood or ebb tide. 


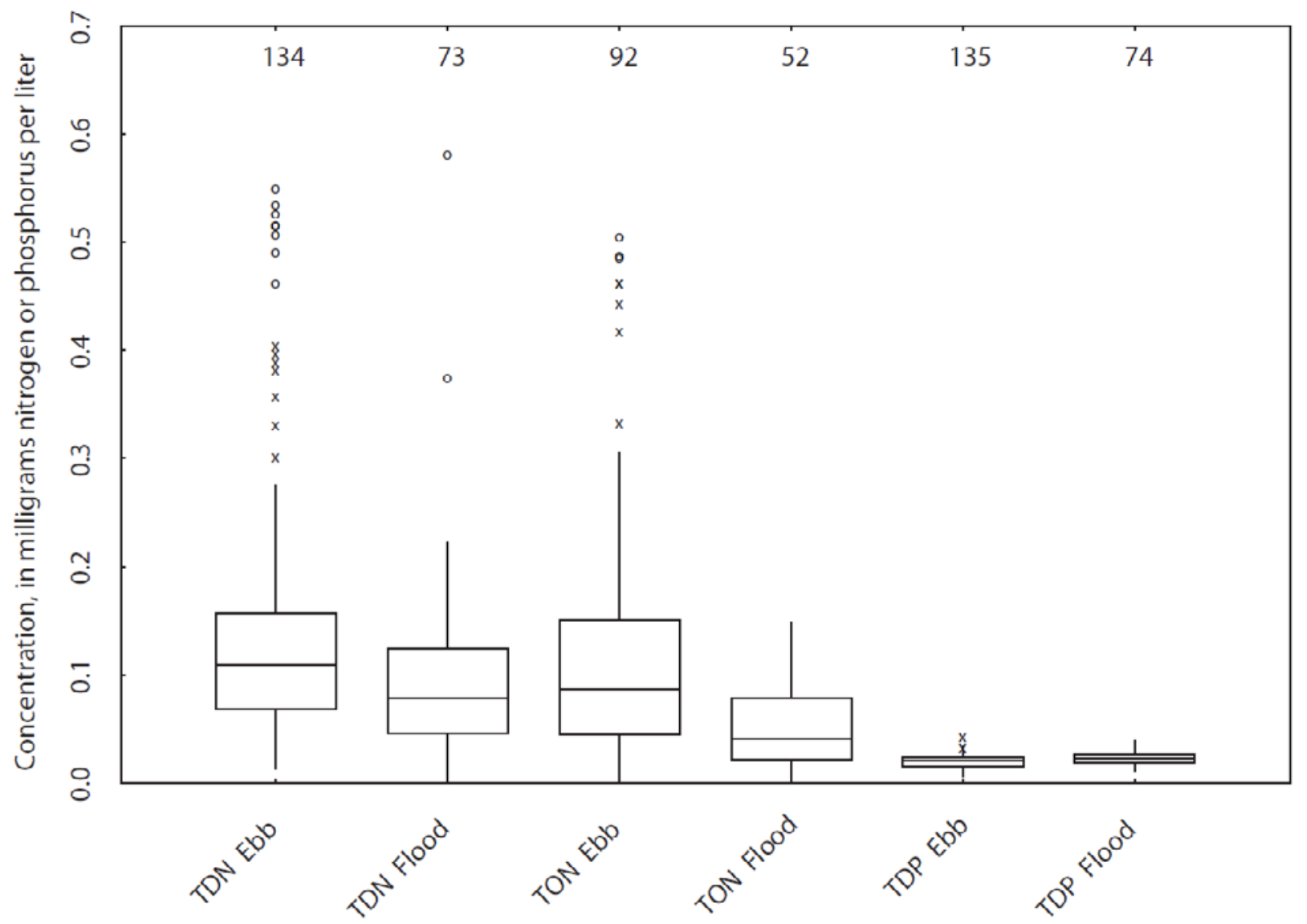

Figure 11. Graph showing concentrations of total dissolved nitrogen (TDN) and total dissolved organic nitrogen (TON) in flood and ebb tides at the Bass Harbor Marsh estuary outlet, Mount Desert Island, Maine, during 2011 and 2012. Box and whisker plots show median, quartiles, 10th and 90th deciles, outliers, and the number of samples analyzed. Numbers at the top of the graph are the total number of samples analyzed for the indicated constituent in flood or ebb tide. 


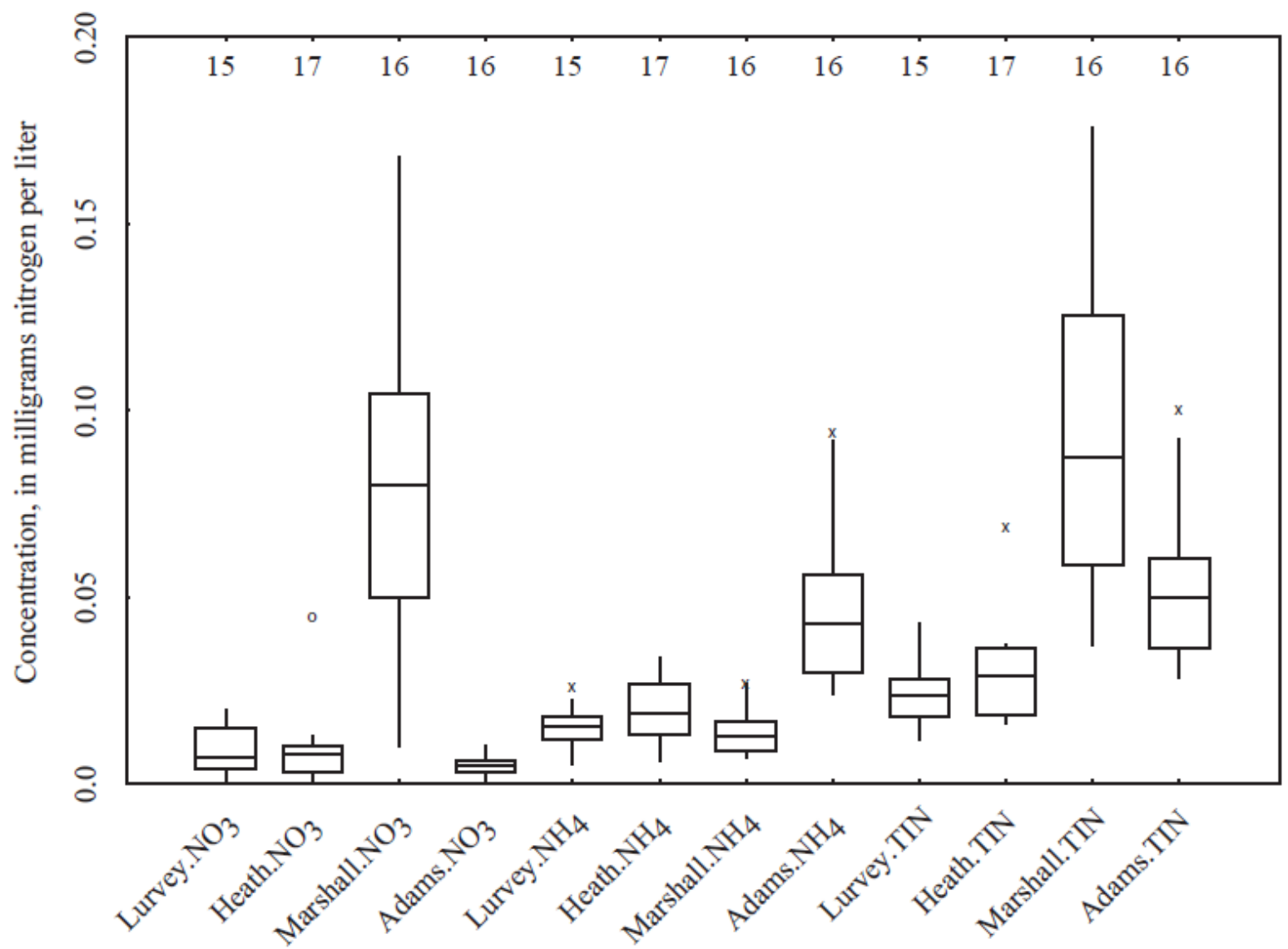

Figure 12. Graph showing concentrations of inorganic nitrogen in tributaries draining into the Bass Harbor Marsh estuary, Mount Desert Island, Maine, in 2012 and 2012. Box and whisker plots show median, 25th and 75th quartiles. Whiskers show the last observation within $1.5 \mathrm{x}$ the interquartile range (IQR, distance between the 25th and 75th quartiles). The "x" symbol indicates observations between 1.5 and 3.0 times the IQR and the "o" symbol indicates observations greater than 3 times the IQR. Numbers at the top of the graph are the total number of samples analyzed for the indicated constituent in flood or ebb tide. 


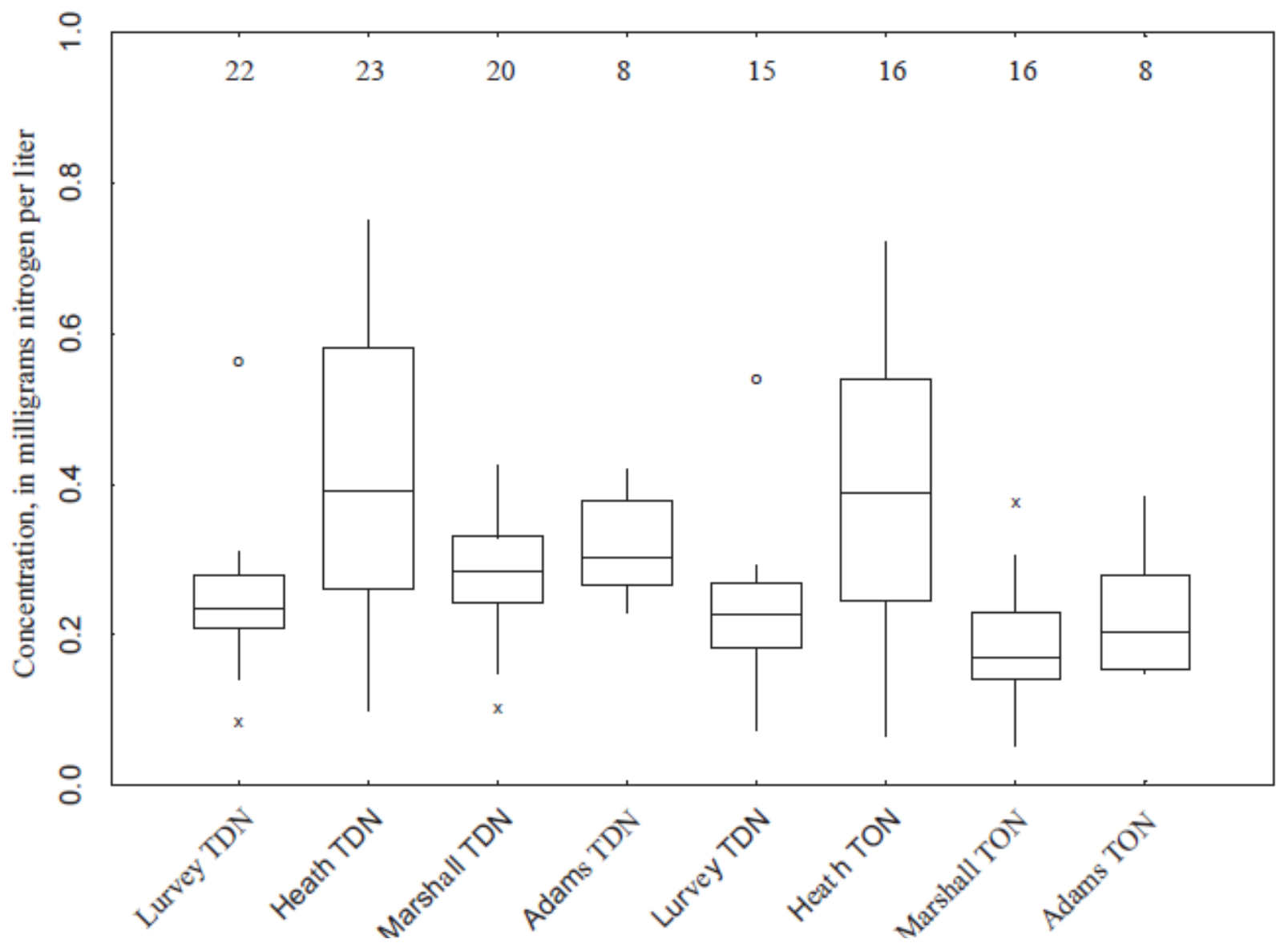

Figure 13. Graph showing total dissolved nitrogen and dissolved organic nitrogen in tributaries draining into the Bass Harbor Marsh estuary, Mount Desert Island, Maine. Box and whisker plots show median, 25th and 75 th quartiles. Whiskers show the last observation within $1.5 \mathrm{x}$ the interquartile range (IQR, distance between the 25th and 75th quartiles). The " $x$ " symbol indicates observations between 1.5 and 3.0 times the IQR and the "O" symbol indicates observations greater than 3 times the IQR. Numbers at the top of the graph are the total number of samples analyzed for the indicated constituent in flood or ebb tide. 


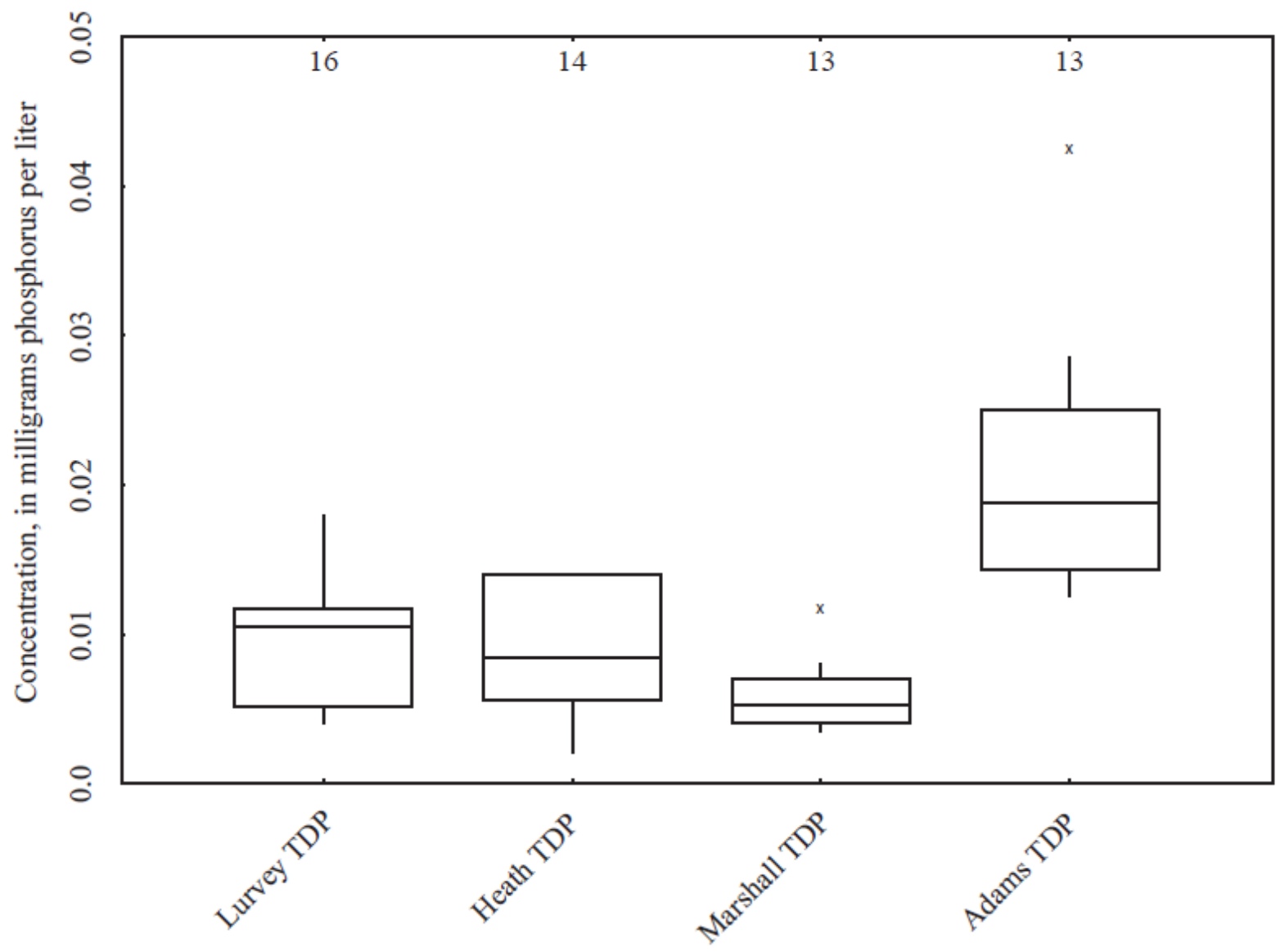

Figure 14. Graph showing total dissolved phosphorus (TDP) in tributaries draining into the Bass Harbor Marsh estuary, Mount Desert Island, Maine. Box and whisker plots show median, 25th and 75th quartiles. Whiskers show the last observation within $1.5 x$ the interquartile range (IQR, distance between the 25th and 75th quartiles). The " $x$ " symbol indicates observations between 1.5 and 3.0 times the IQR and the "o" symbol indicates observations greater than 3 times the IQR. Numbers at the top of the graph are the total number of samples analyzed for the indicated constituent in flood or ebb tide. 


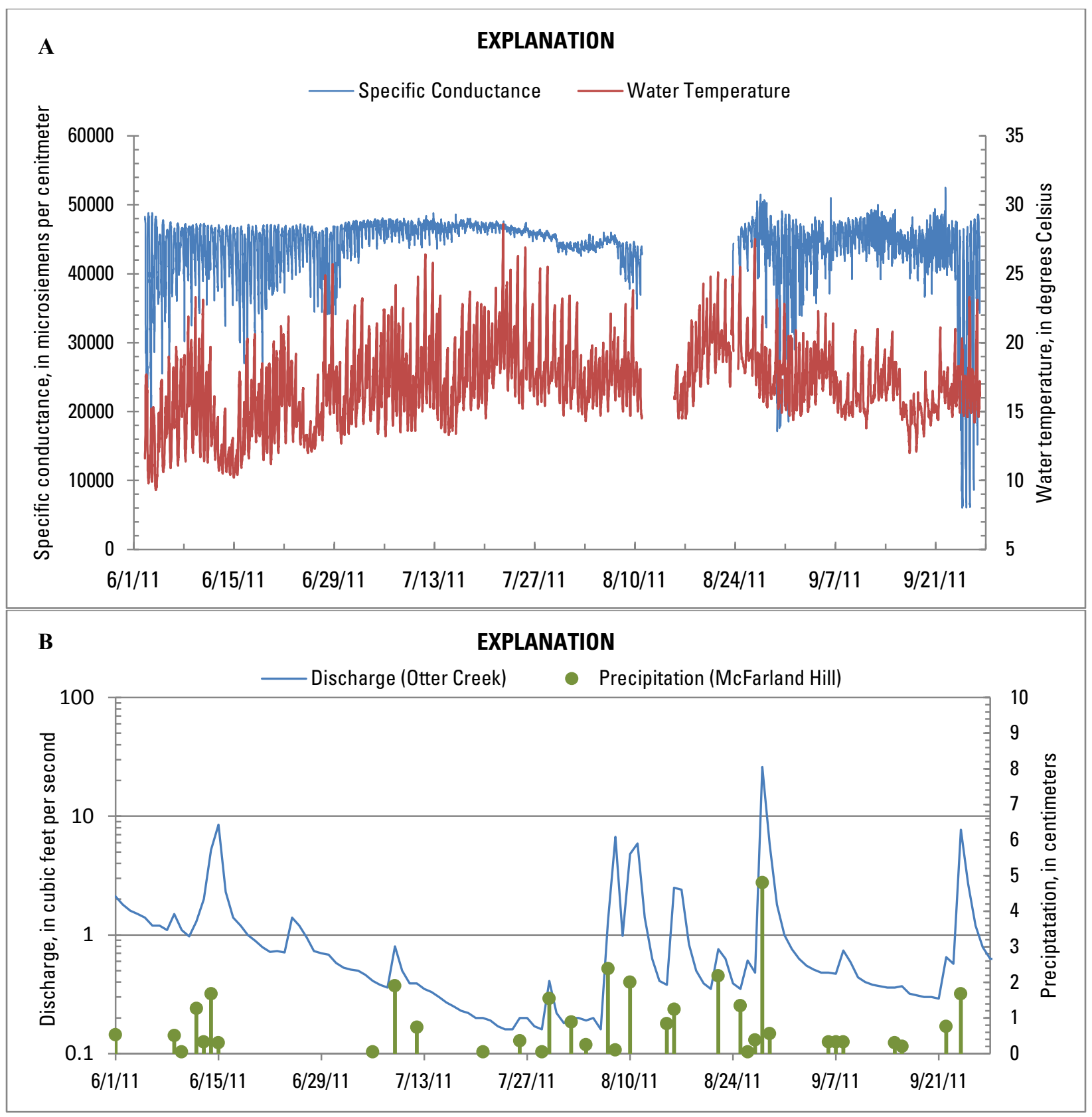

Figure 15. Graphs showing $A$, continuous specific conductance and water temperature at the Bass Harbor Marsh estuary outlet, Mount Desert Island, Maine, during June through September 2011, and B, discharge at Otter Creek and precipitation at McFarland Hill, Mount Desert Island, Maine, during June through September 2011. 

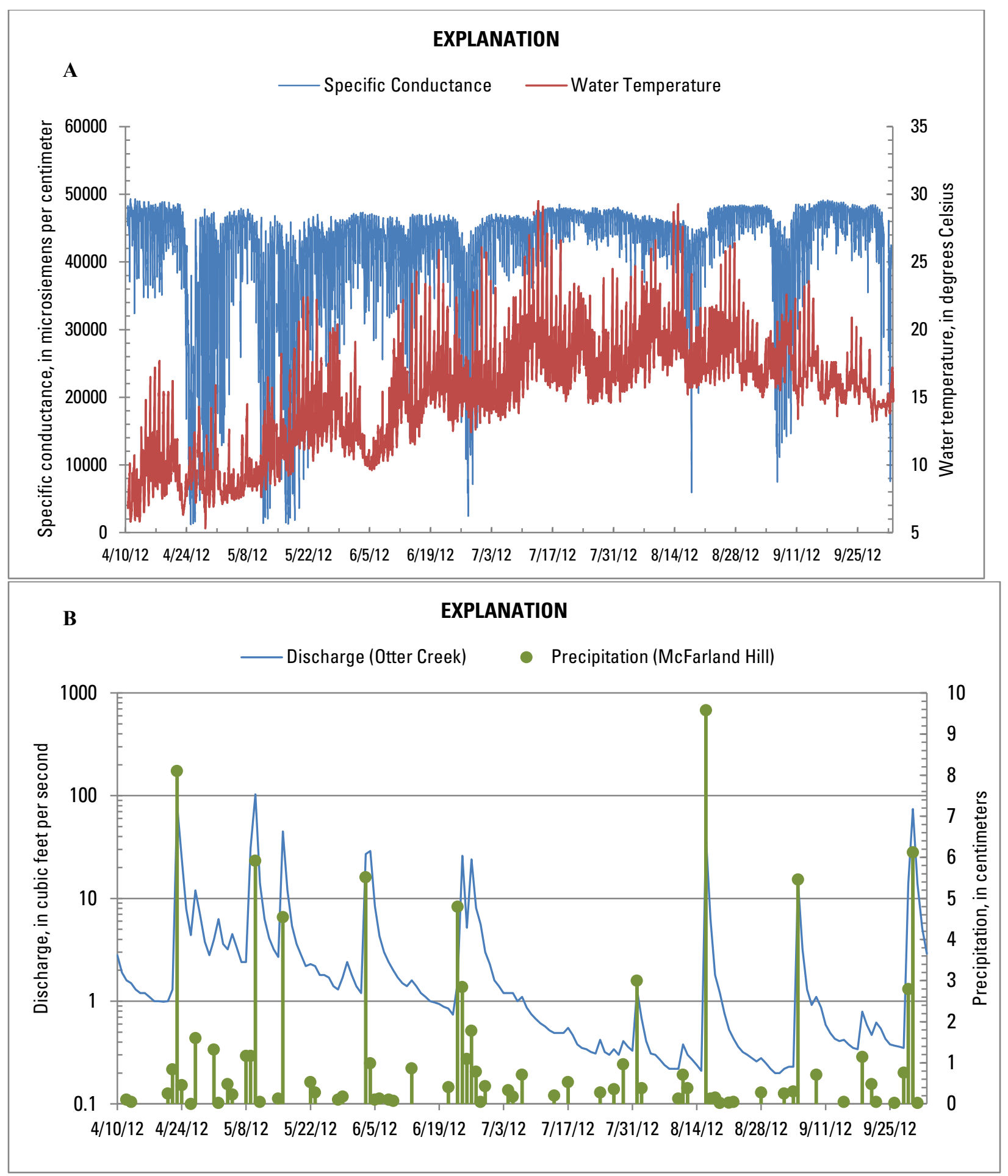

Figure 16. Graphs showing $A$, continuous specific conductance and water temperature at the Bass Harbor Marsh estuary outlet, Mount Desert Island, Maine, during June through September 2012, and B, discharge at Otter Creek and precipitation at McFarland Hill, Mount Desert Island, Maine, during April through September 2012. 

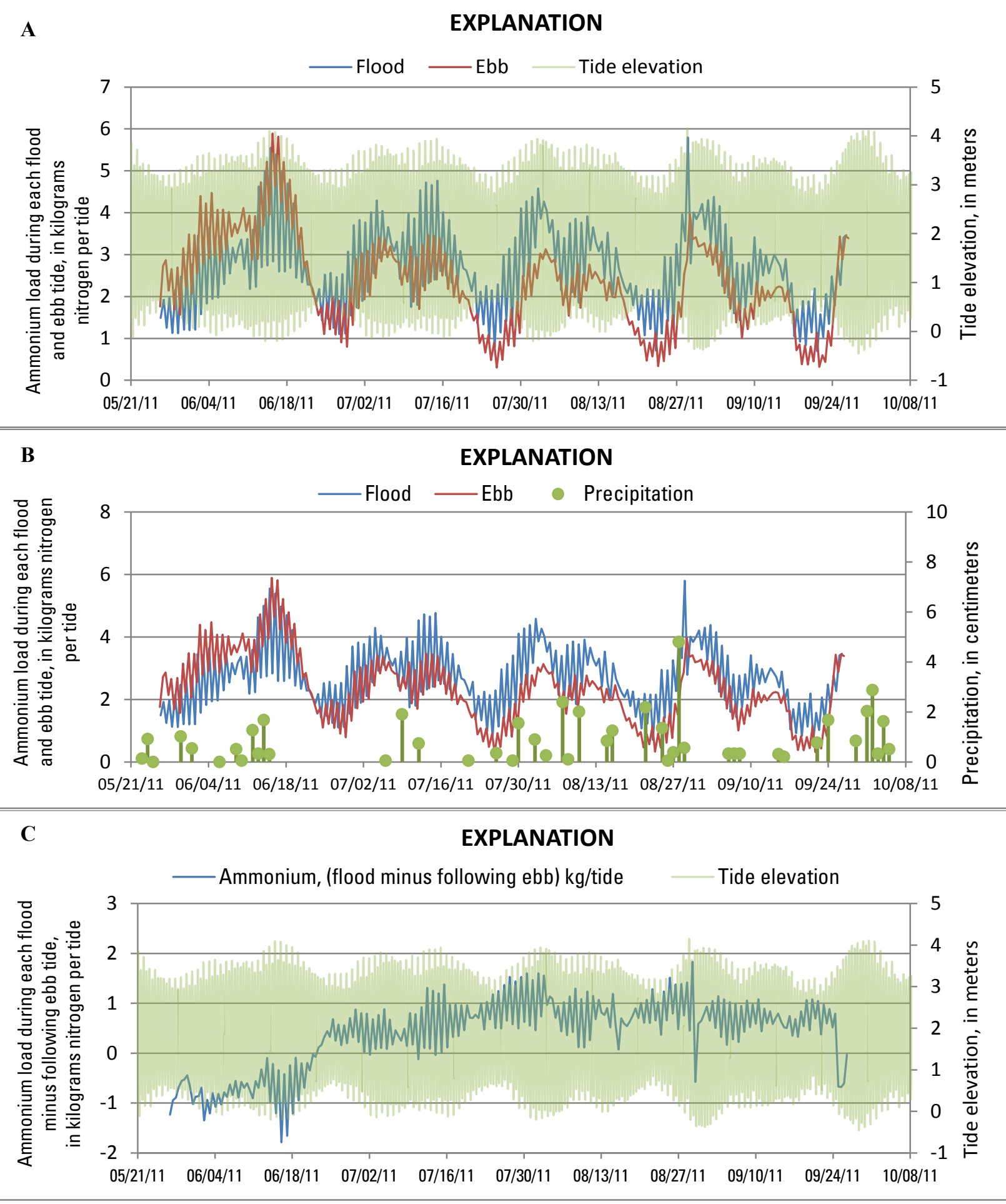

Figure 17. Graphs showing A, calculated tidal load of ammonium across the ocean-estuary boundary of Bass Harbor Marsh estuary in 2011 and tidal elevation in Bar Harbor, Maine; B, calculated tidal load of ammonium and daily precipitation recorded at McFarland Hill on Mount Desert Island, Maine; and $C$, calculated net tidal exchange (expressed as load, kg nitrogen per tide) during each tidal cycle (flood tide minus following ebb tide). 

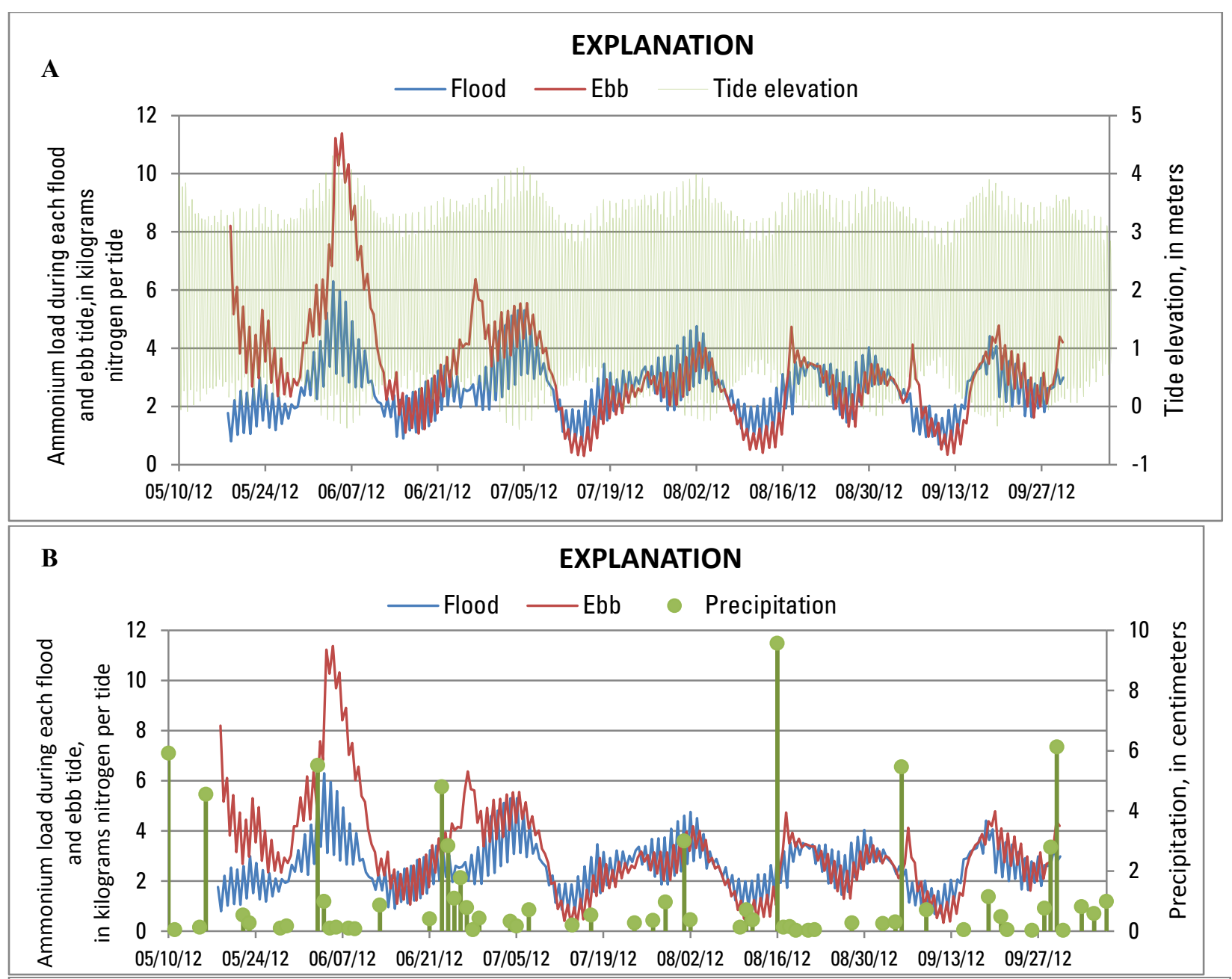

C EXPLANATION

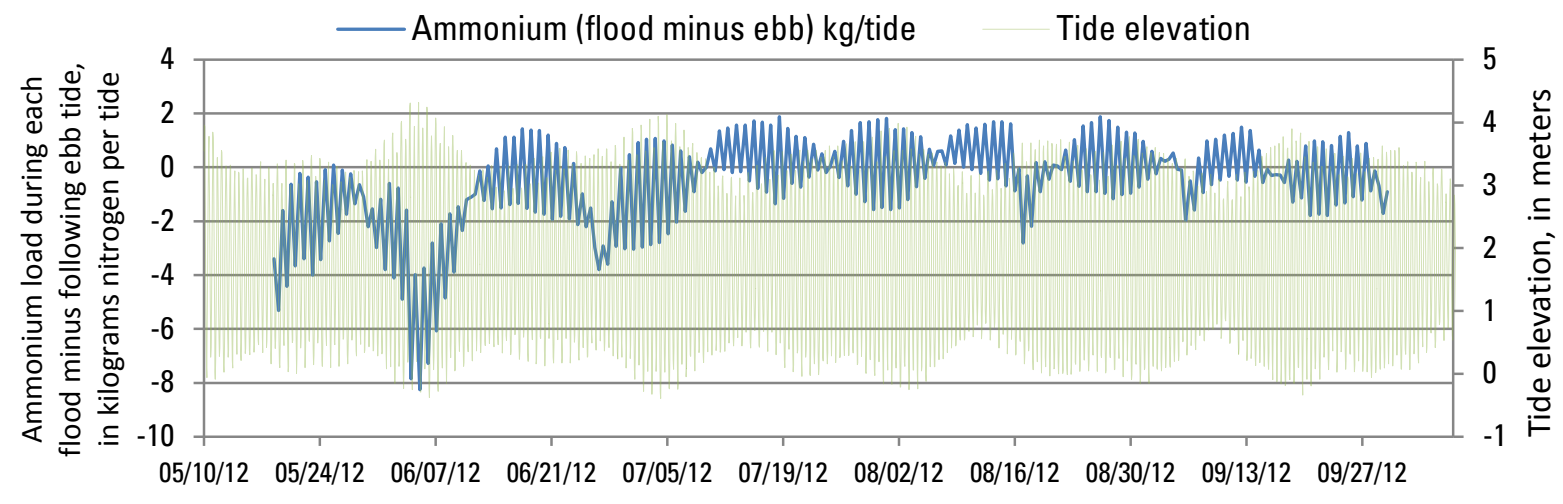

Figure 18. Graphs showing $A$, calculated tidal load of ammonium across the ocean-estuary boundary for Bass Harbor Marsh estuary in 2012 and tidal elevation in Bar Harbor, Maine; $B$, calculated tidal load of ammonium and daily precipitation recorded at McFarland Hill on Mount Desert Island, Maine; and C, calculated net tidal exchange (expressed as load, kg nitrogen per tide) during each tidal cycle (flood tide minus following ebb tide). 

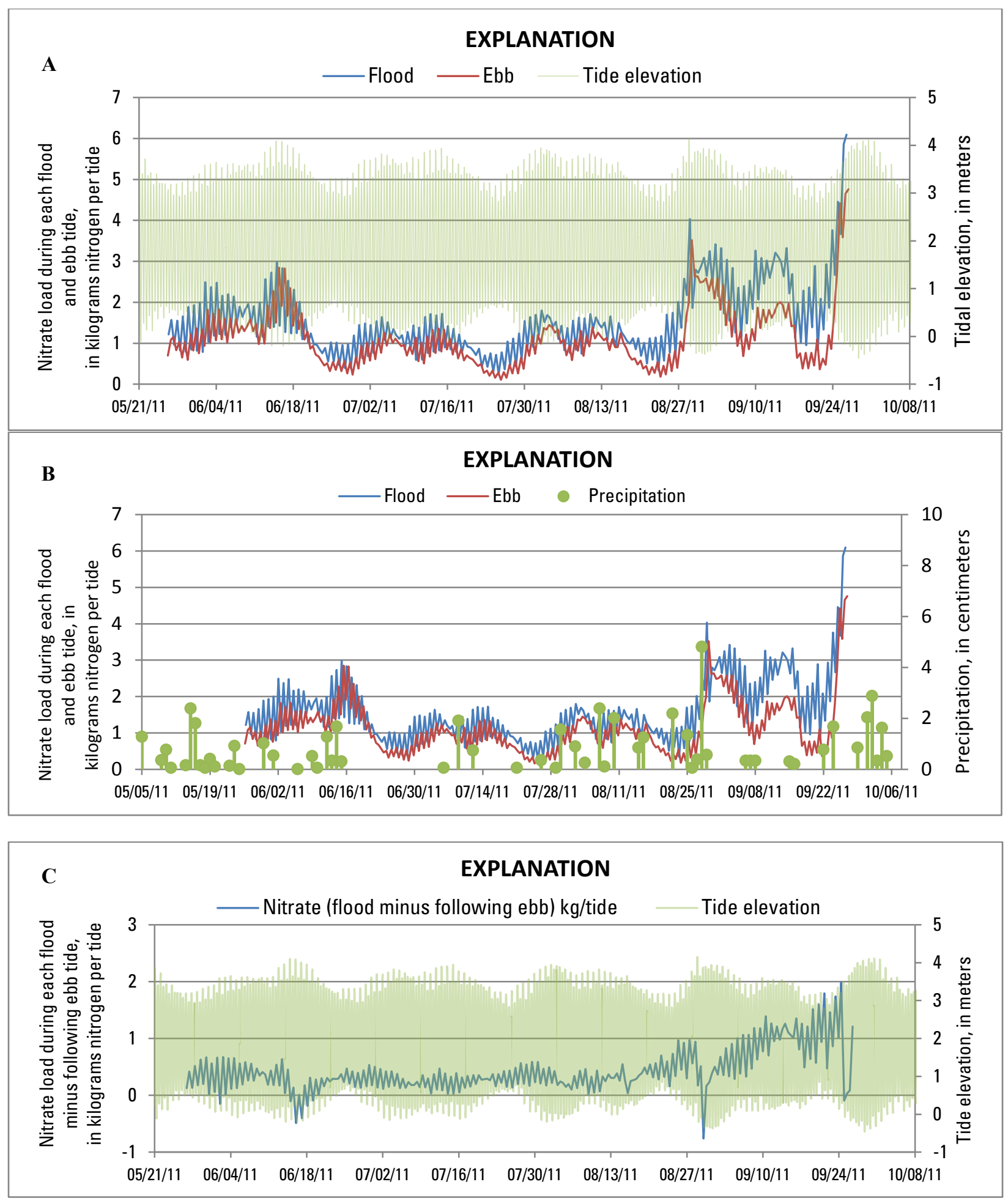

Figure 19. Graphs showing $A$, calculated tidal load of nitrate across the ocean-estuary boundary for Bass Harbor Marsh estuary in 2011 and tidal elevation in Bar Harbor, Maine; B, calculated tidal load of nitrate and daily precipitation recorded at McFarland Hill on Mount Desert Island, Maine; and $C$, calculated net tidal exchange (expressed as load, $\mathrm{kg}$ nitrogen per tide) during each tidal cycle (flood tide minus following ebb tide). 

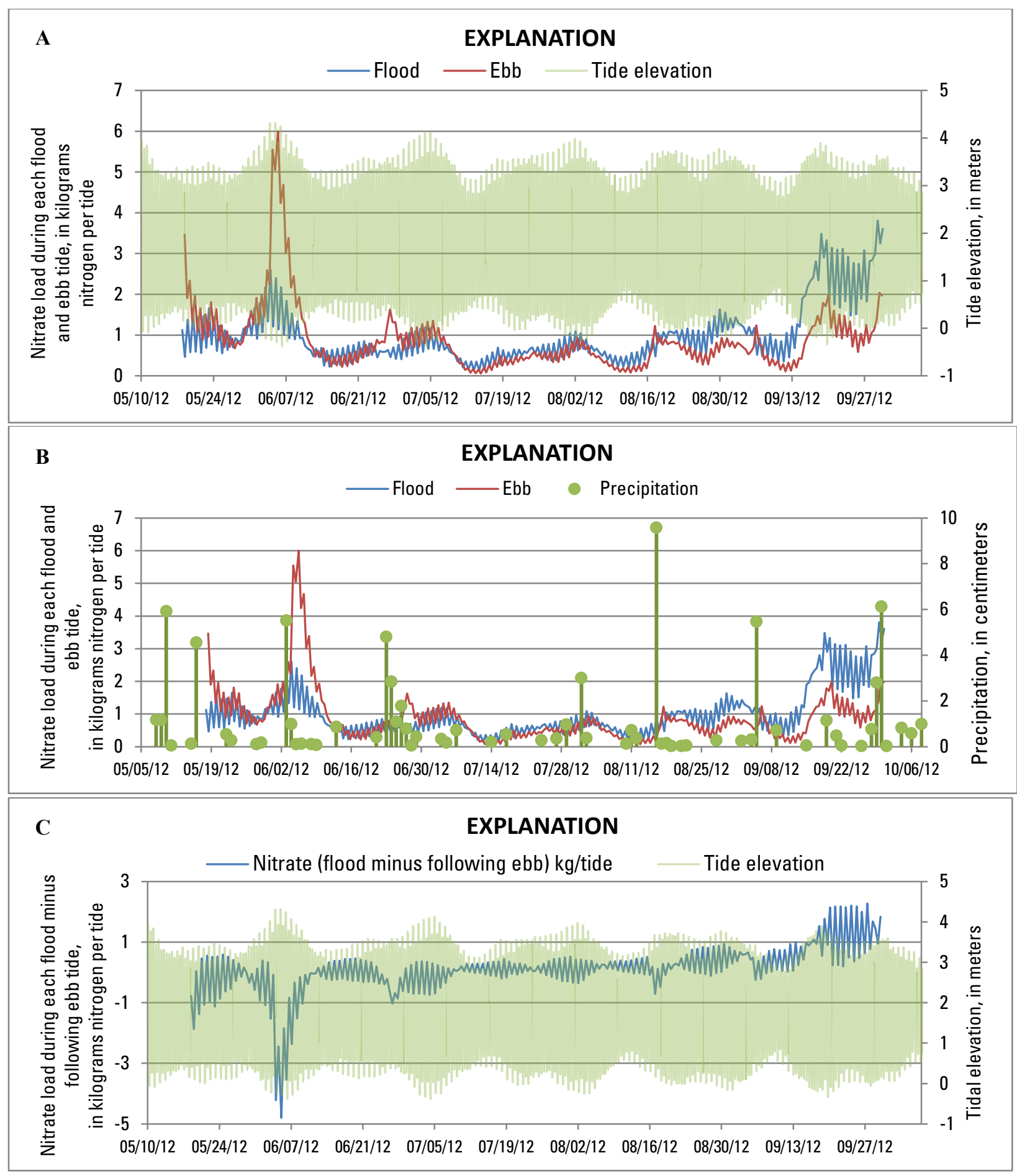

Figure 20. Graphs showing A, calculated tidal load of nitrate across the ocean-estuary boundary for Bass Harbor Marsh estuary in 2012 and tidal elevation in Bar Harbor, Maine; B, calculated tidal load of nitrate and daily precipitation recorded at McFarland Hill on Mount Desert Island, Maine; and C, calculated net tidal exchange (expressed as load, kg nitrogen per tide) during each tidal cycle (flood tide minus following ebb tide). 

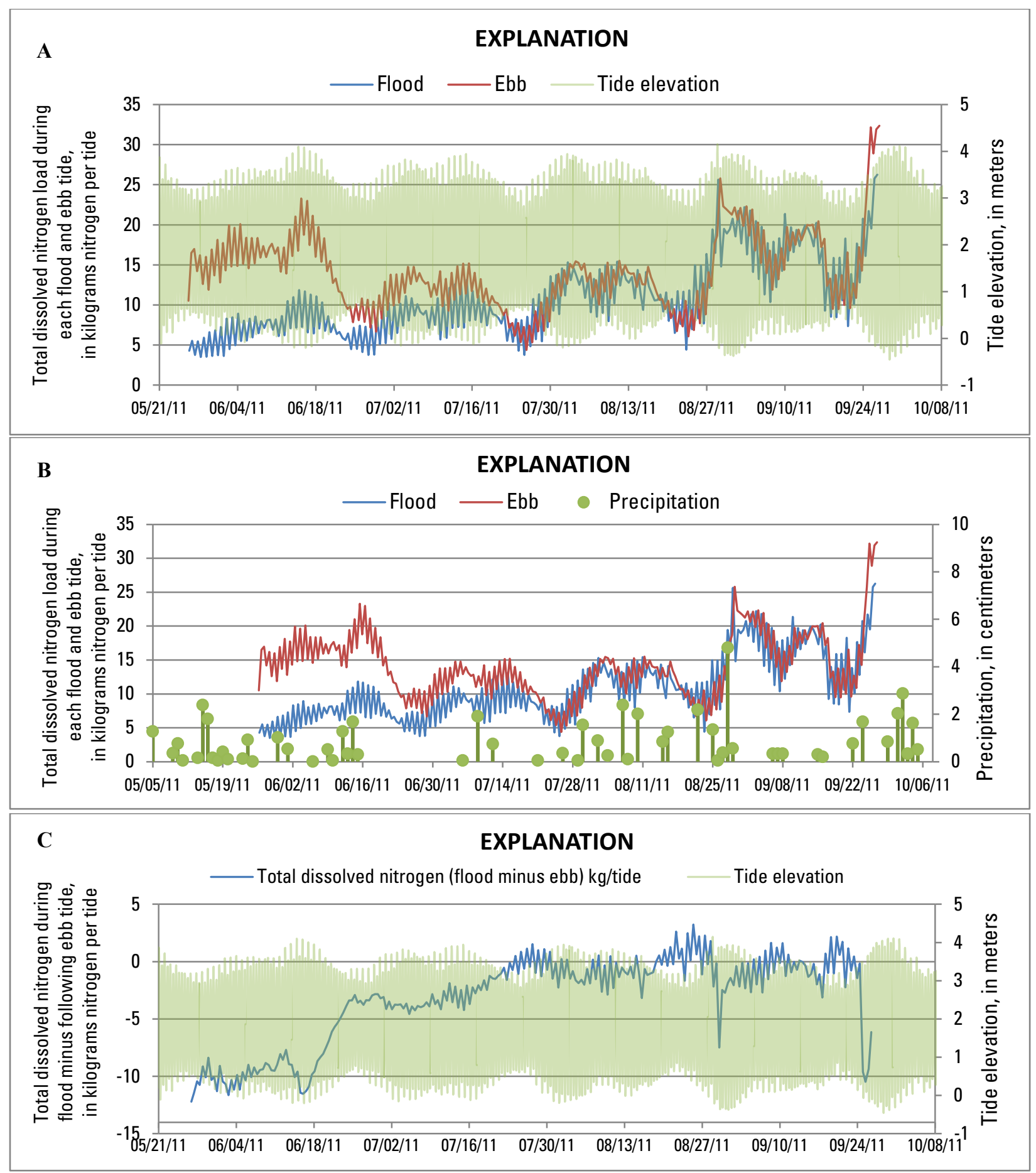

Figure 21. Graphs showing $A$, calculated tidal load of total dissolved nitrogen across the ocean-estuary boundary for Bass Harbor Marsh estuary in 2011 and tidal elevation in Bar Harbor, Maine; $B$, calculated tidal load of total dissolved nitrogen and daily precipitation recorded at McFarland Hill on Mount Desert Island, Maine; and C, calculated net tidal exchange (expressed as load, kg nitrogen per tide) during each tidal cycle (flood tide minus following ebb tide). 


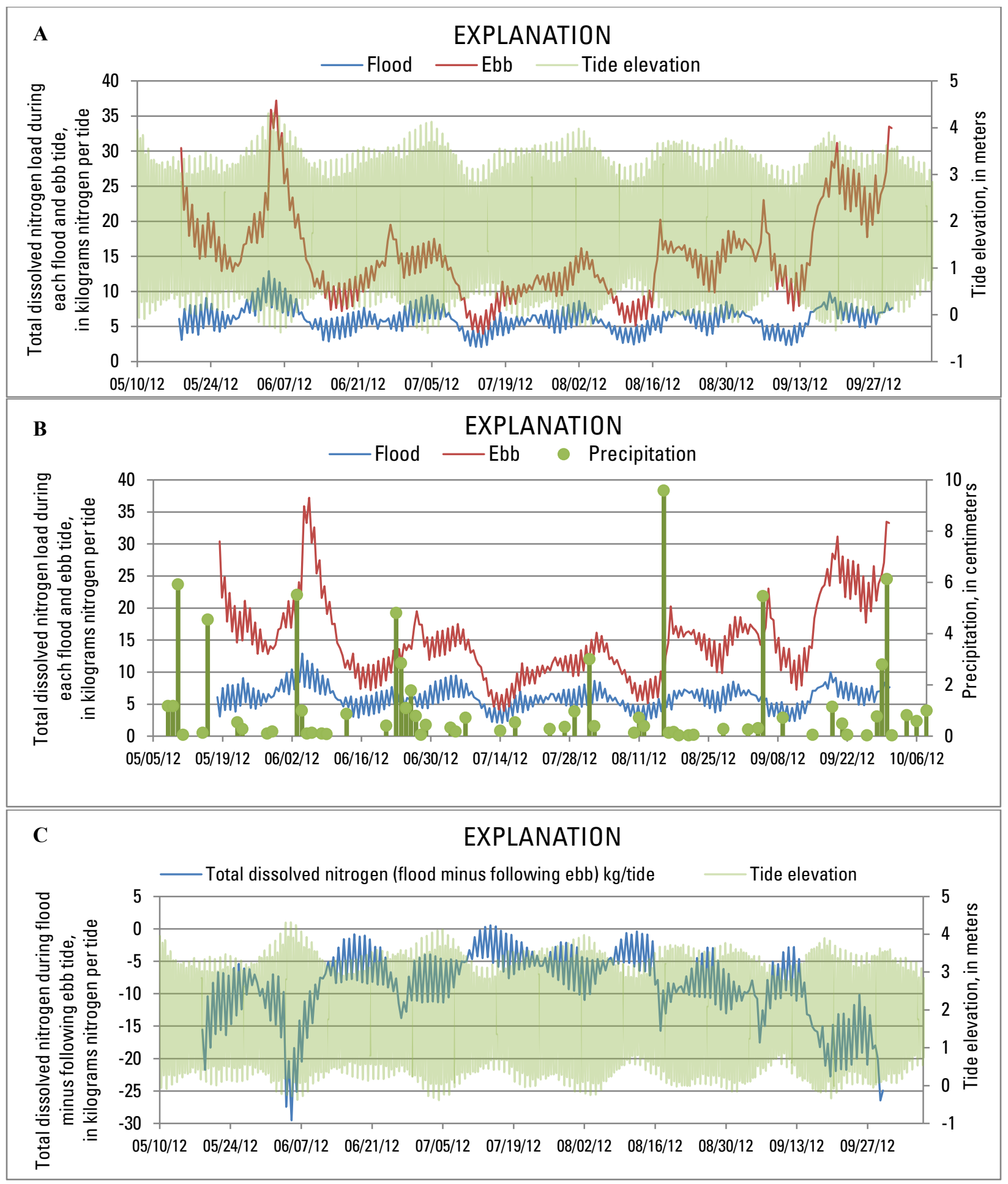

Figure 22. Graphs showing $A$, calculated tidal load of total dissolved nitrogen across the ocean-estuary boundary for Bass Harbor Marsh estuary in 2012 and tidal elevation in Bar Harbor, Maine; B, calculated tidal load of total dissolved nitrogen and daily precipitation recorded at McFarland Hill on Mount Desert Island, Maine; and C, calculated net tidal exchange (expressed as load, $\mathrm{kg}$ nitrogen per tide) during each tidal cycle (flood tide minus following ebb tide). 

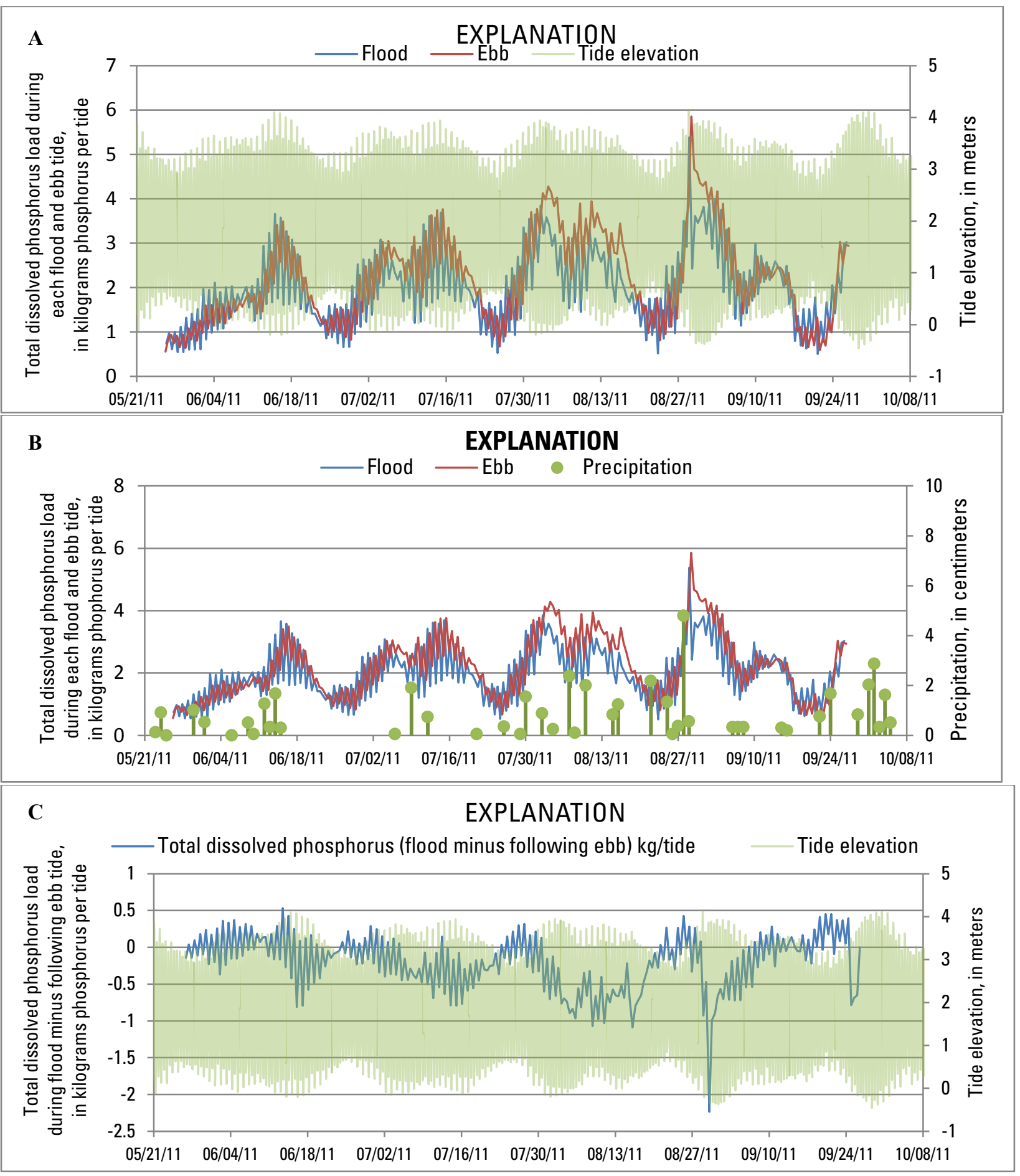

Figure 23. Graphs showing $A$, calculated tidal load of total dissolved phosphorus across the ocean-estuary boundary for Bass Harbor Marsh estuary in 2011 and tidal elevation in Bar Harbor, Maine; $B$, calculated tidal load of phosphorus and daily precipitation recorded at McFarland Hill on Mount Desert Island, Maine; and $C$, calculated net tidal exchange (expressed as load, kg phosphorus per tide) during each tidal cycle (flood tide minus following ebb tide). 

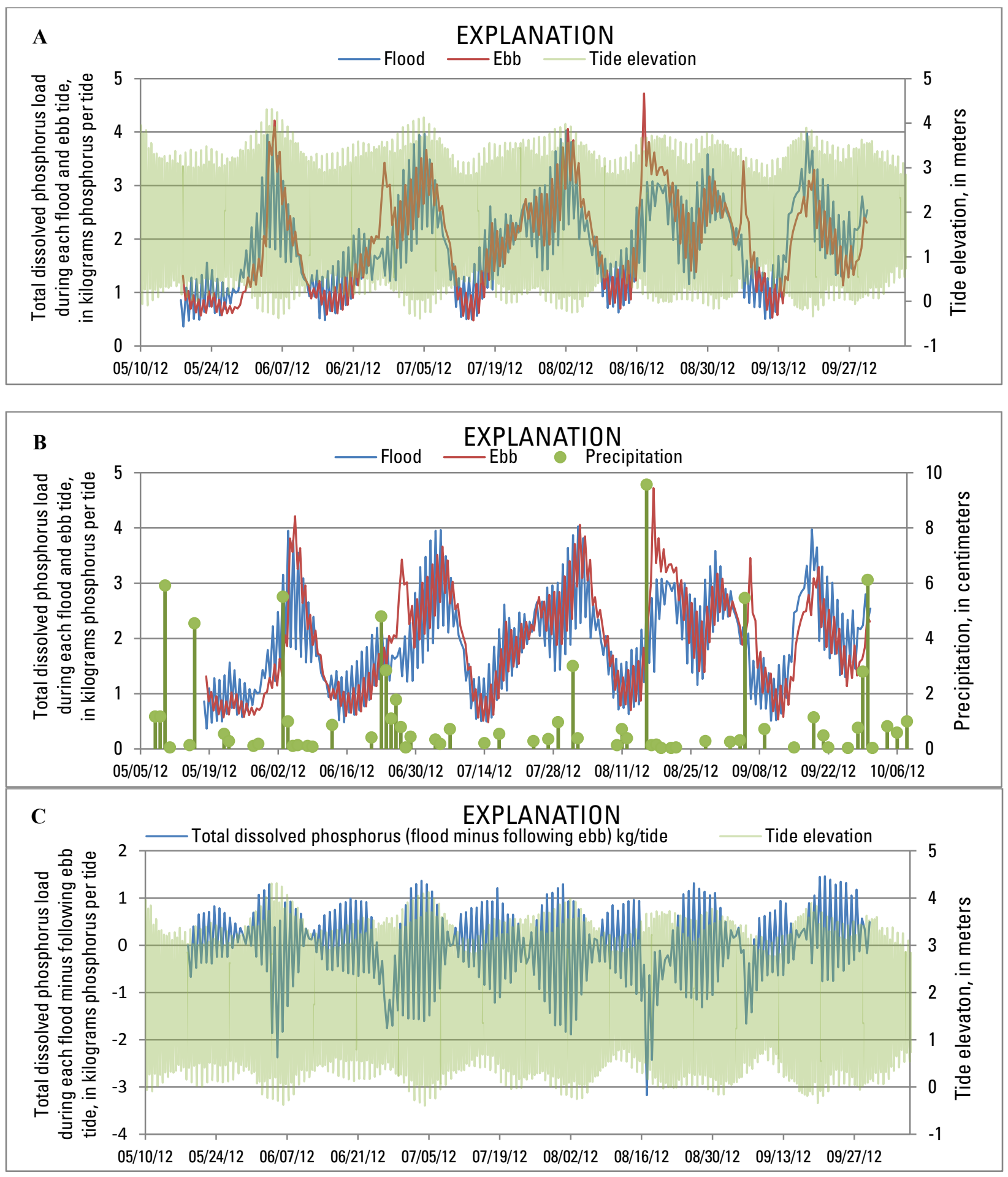

Figure 24. Graphs showing $A$, calculated tidal load of total dissolved phosphorus across the ocean-estuary boundary for Bass Harbor Marsh estuary in 2012 and tidal elevation in Bar Harbor, Maine; $B$, calculated tidal load of phosphorus and daily precipitation recorded at McFarland Hill on Mount Desert Island, Maine; and $C$, calculated net tidal exchange (expressed as load, kg phosphorus per tide) during each tidal cycle (flood tide minus following ebb tide). 


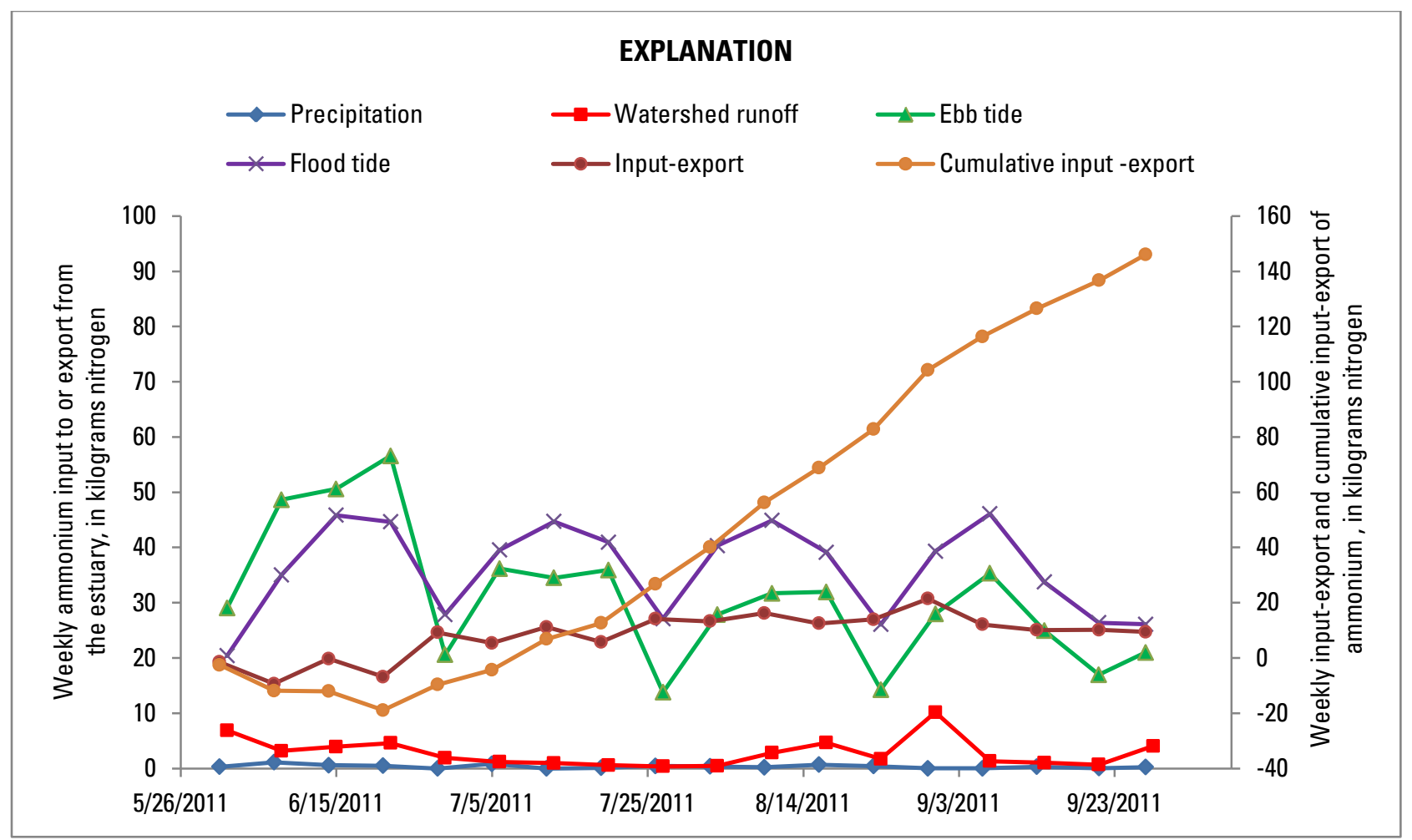

Figure 25. Graph showing weekly ammonium $\left(\mathrm{NH}_{4}\right)$ inputs to the estuary (from precipitation, watershed runoff, and ebb tides) and exports from the Bass Harbor Marsh estuary (flood tide) in 2011, Mount Desert Island, Maine. 


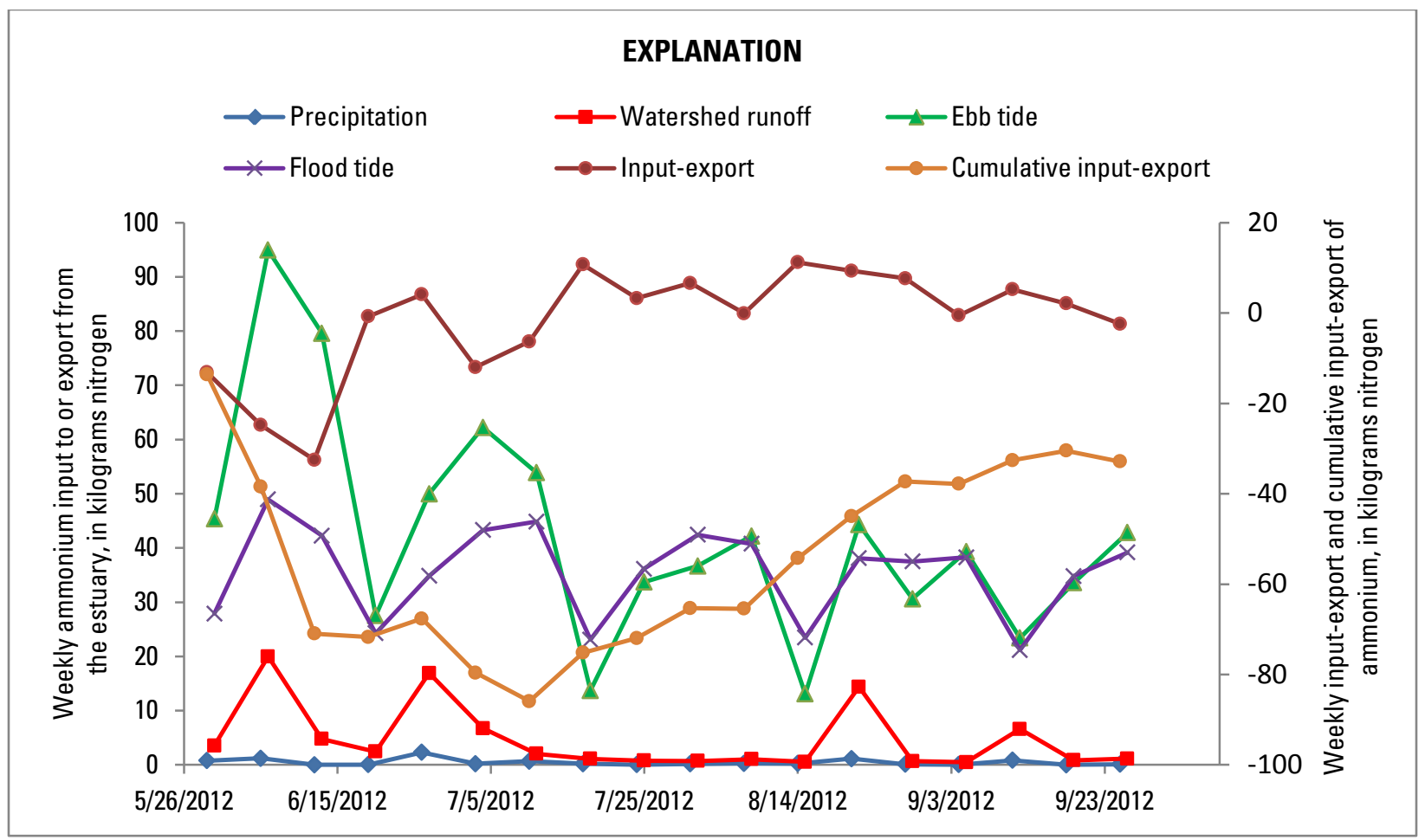

Figure 26. Graph showing weekly ammonium $\left(\mathrm{NH}_{4}\right)$ inputs to the estuary (from precipitation, watershed runoff, and ebb tides) and exports from the Bass Harbor Marsh estuary (flood tide) in 2012, Mount Desert Island, Maine 


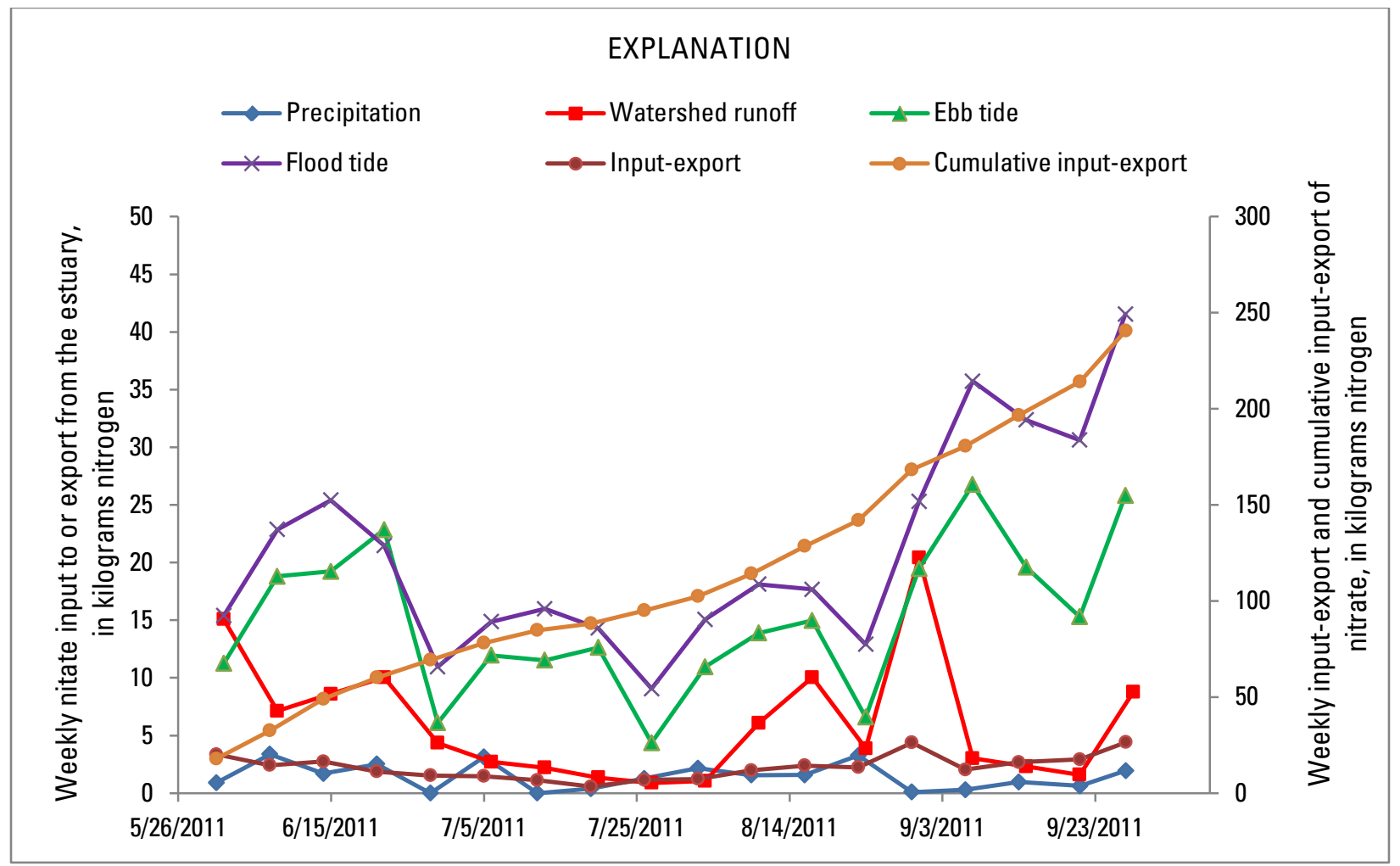

Figure 27. Graph showing weekly nitrate $\left(\mathrm{NO}_{3}\right)$ inputs to the estuary (from precipitation, watershed runoff, and ebb tides) and exports from the Bass Harbor Marsh estuary (flood tide) in 2011, Mount Desert Island, Maine. 


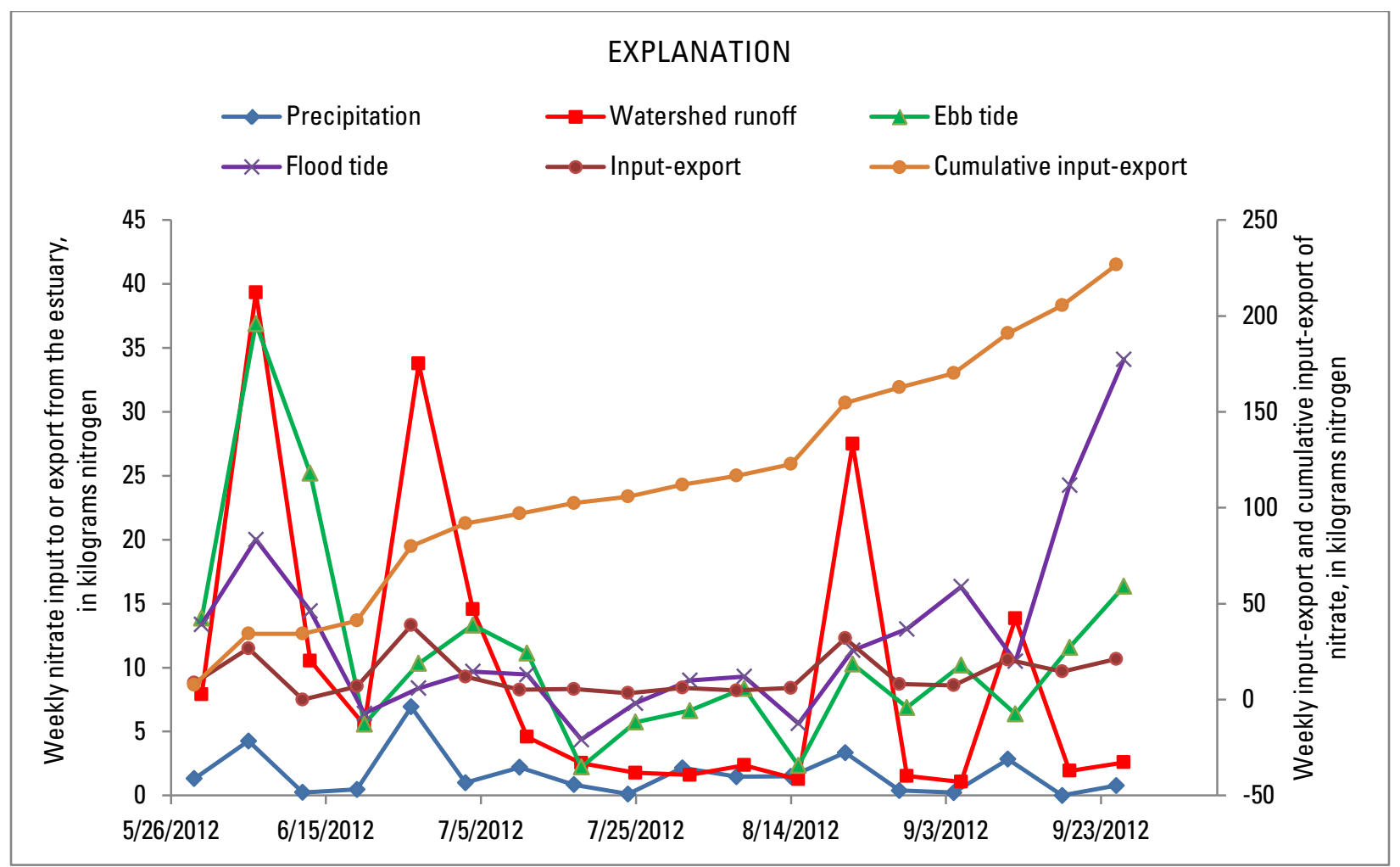

Figure 28. Graph showing weekly nitrate $\left(\mathrm{NO}_{3}\right)$ inputs to the estuary (from precipitation, watershed runoff, and ebb tides) and exports from the Bass Harbor Marsh estuary (flood tide) in 2012, Mount Desert Island, Maine. 


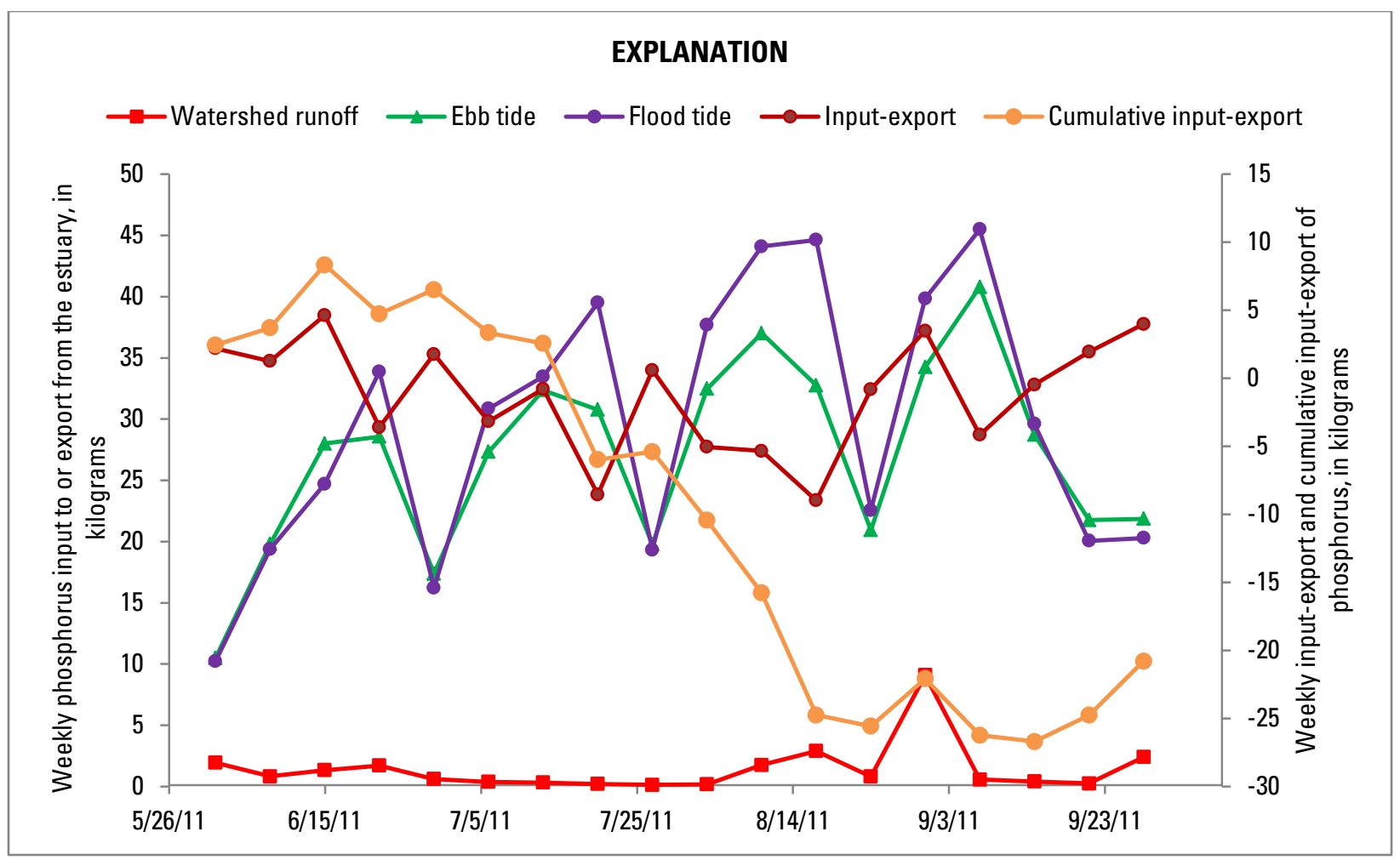

Figure 29. Graph showing weekly phosphorus inputs to the estuary (from precipitation, watershed runoff, and ebb tides) and exports from the Bass Harbor Marsh estuary (flood tide) in 2011, Mount Desert Island, Maine. 


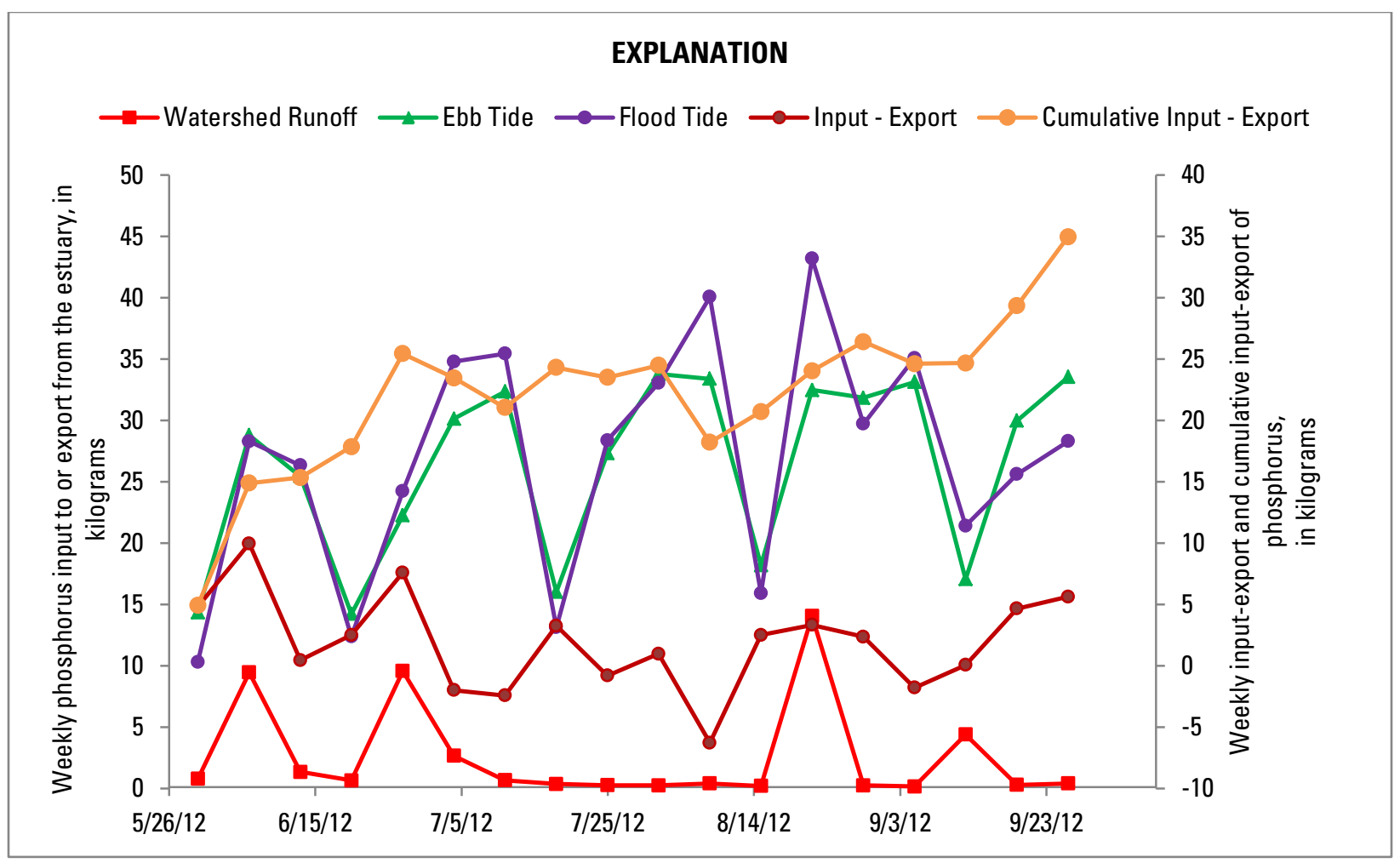

Figure 30. Graph showing weekly phosphorus inputs to the estuary (from precipitation, watershed runoff, and ebb tides) and exports from the Bass Harbor Marsh estuary (flood tide) in 2012, Mount Desert Island, Maine. 


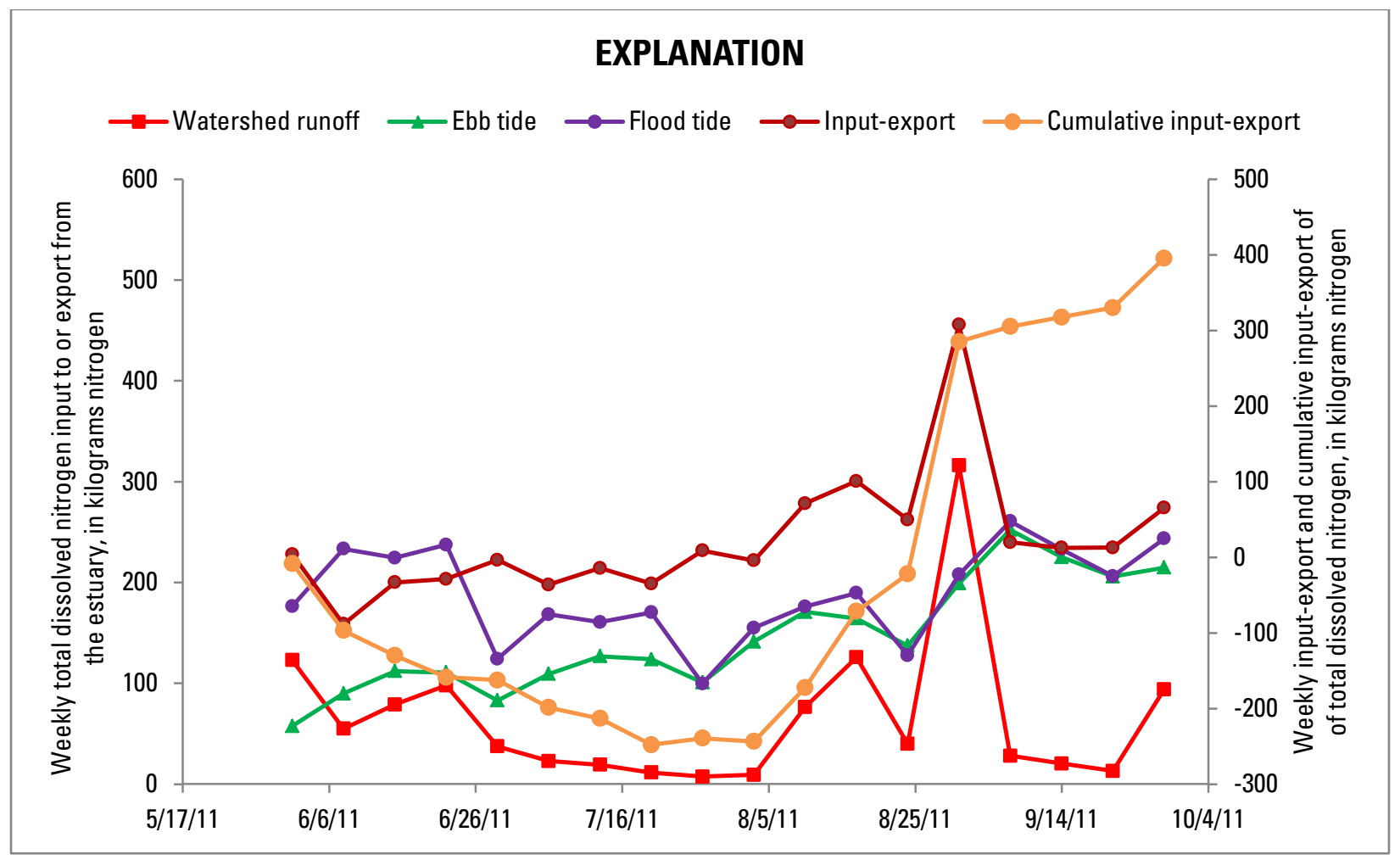

Figure 31. Graph showing weekly total dissolved nitrogen inputs to the estuary (from precipitation, watershed runoff, and ebb tides) and exports from the Bass Harbor Marsh estuary (flood tide) in 2011, Mount Desert Island, Maine. 


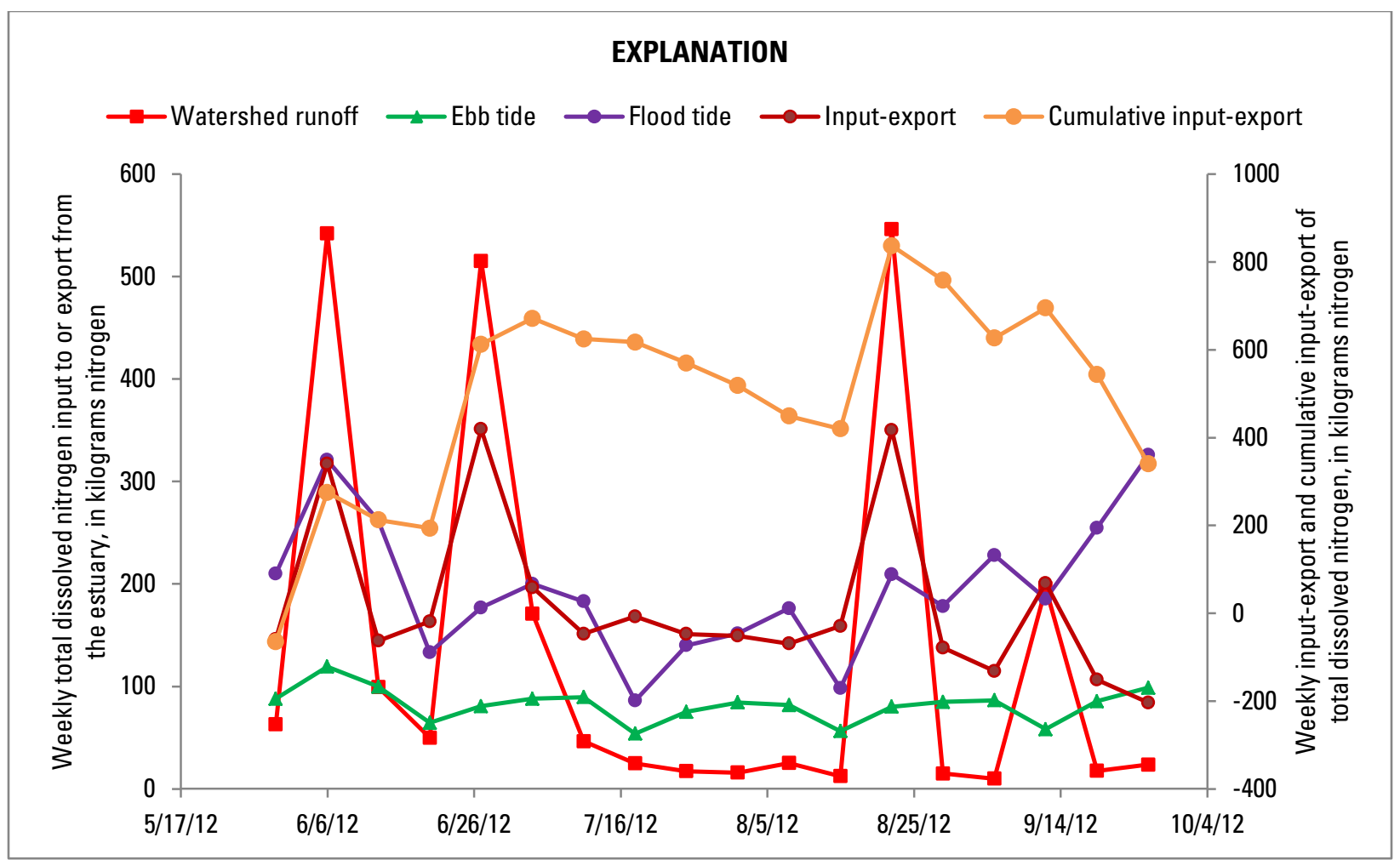

Figure 32. Graph showing weekly total dissolved nitrogen inputs to the estuary (from precipitation, watershed runoff, and ebb tides) and exports from the Bass Harbor Marsh estuary (flood tide) in 2012, Mount Desert Island, Maine. 


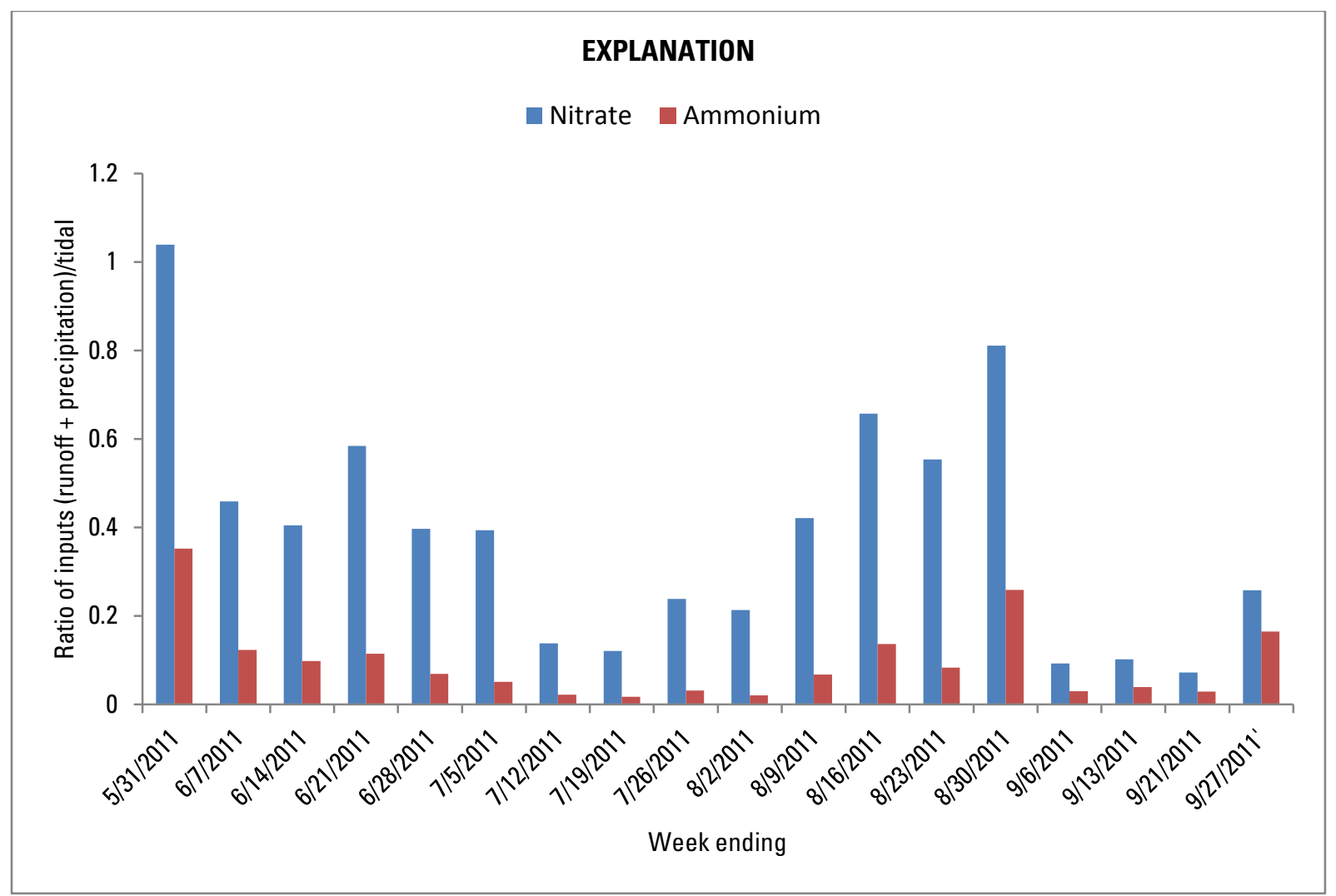

Figure 33. Graph showing ratio of weekly nitrate $\left(\mathrm{NO}_{3}\right)$ and ammonium $\left(\mathrm{NH}_{4}\right)$ inputs in runoff and precipitation to tidal inputs during summer 2011, Bass Harbor Marsh estuary, Mount Desert Island, Maine. 


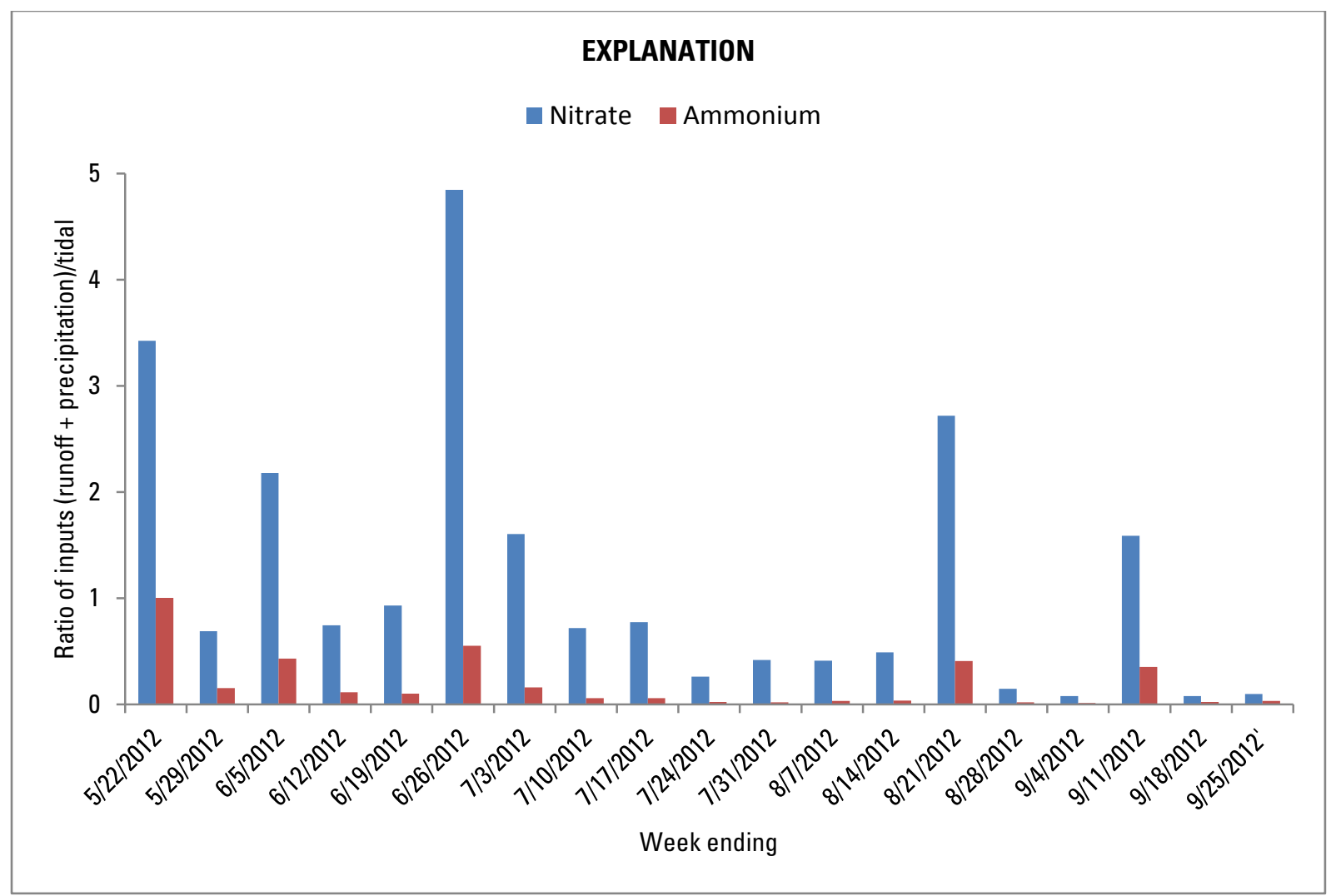

Figure 34. Graph showing ratio of weekly nitrate $\left(\mathrm{NO}_{3}\right)$ and ammonium $\left(\mathrm{NH}_{4}\right)$ inputs in runoff and precipitation to tidal inputs during summer 2012, Bass Harbor Marsh estuary, Mount Desert Island, Maine. 


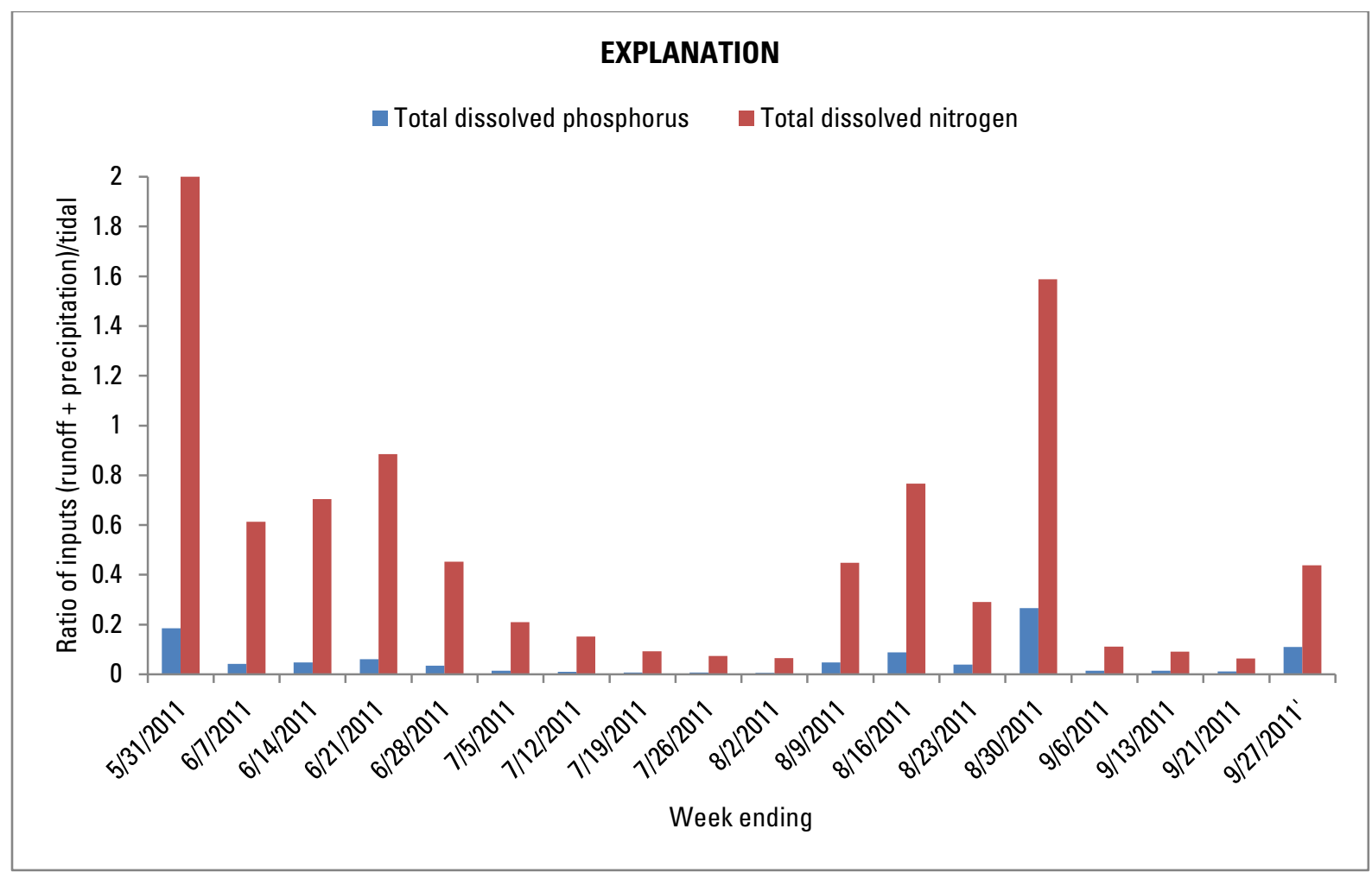

Figure 35. Graph showing ratio of weekly total dissolved nitrogen and phosphorus inputs in runoff and precipitation to tidal inputs during summer 2011, Bass Harbor Marsh estuary, Mount Desert Island, Maine. 


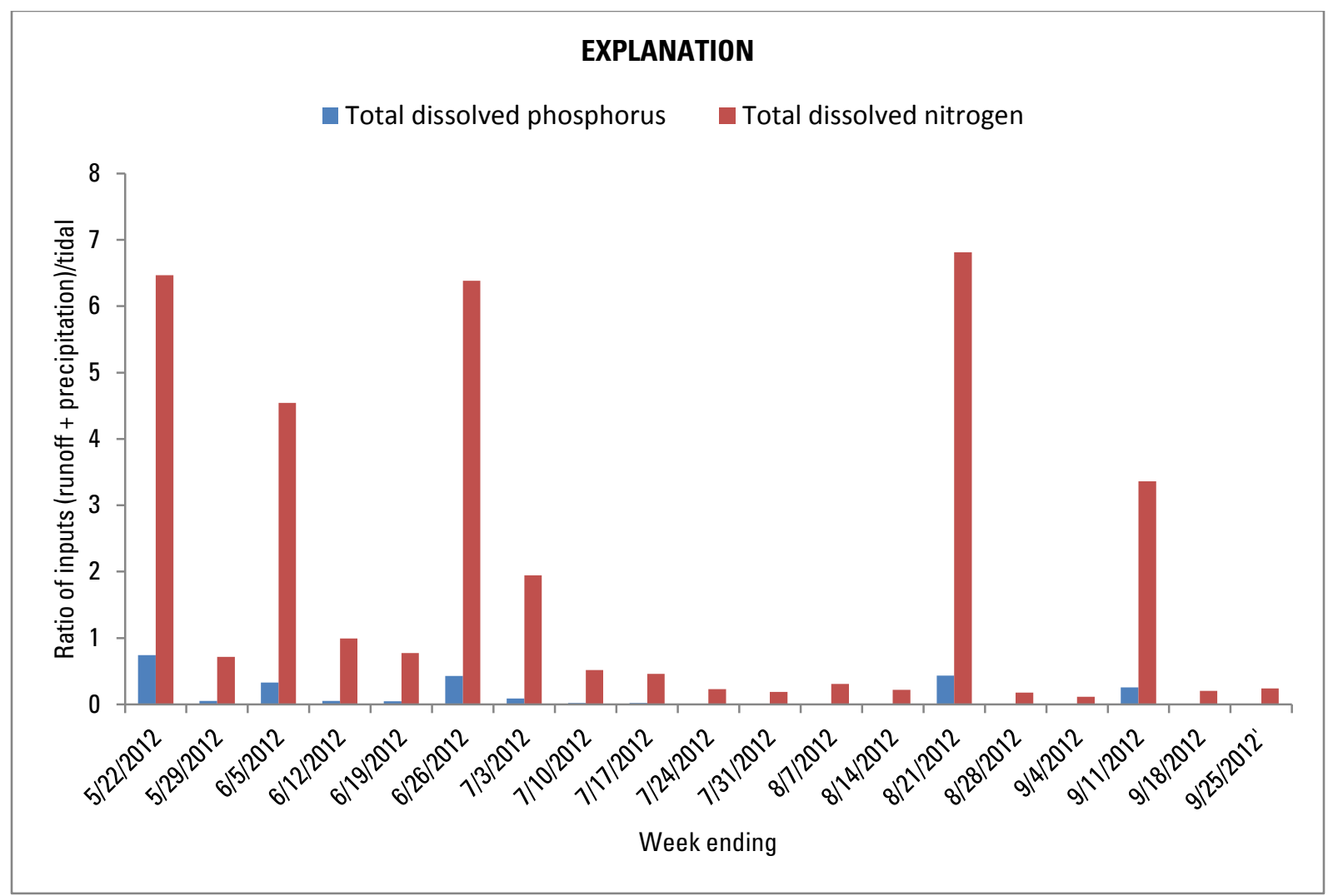

Figure 36. Graph showing ratio of weekly total dissolved nitrogen and phosphorus inputs in runoff and precipitation to tidal inputs during summer 2012, Bass Harbor Marsh estuary, Mount Desert Island, Maine. 


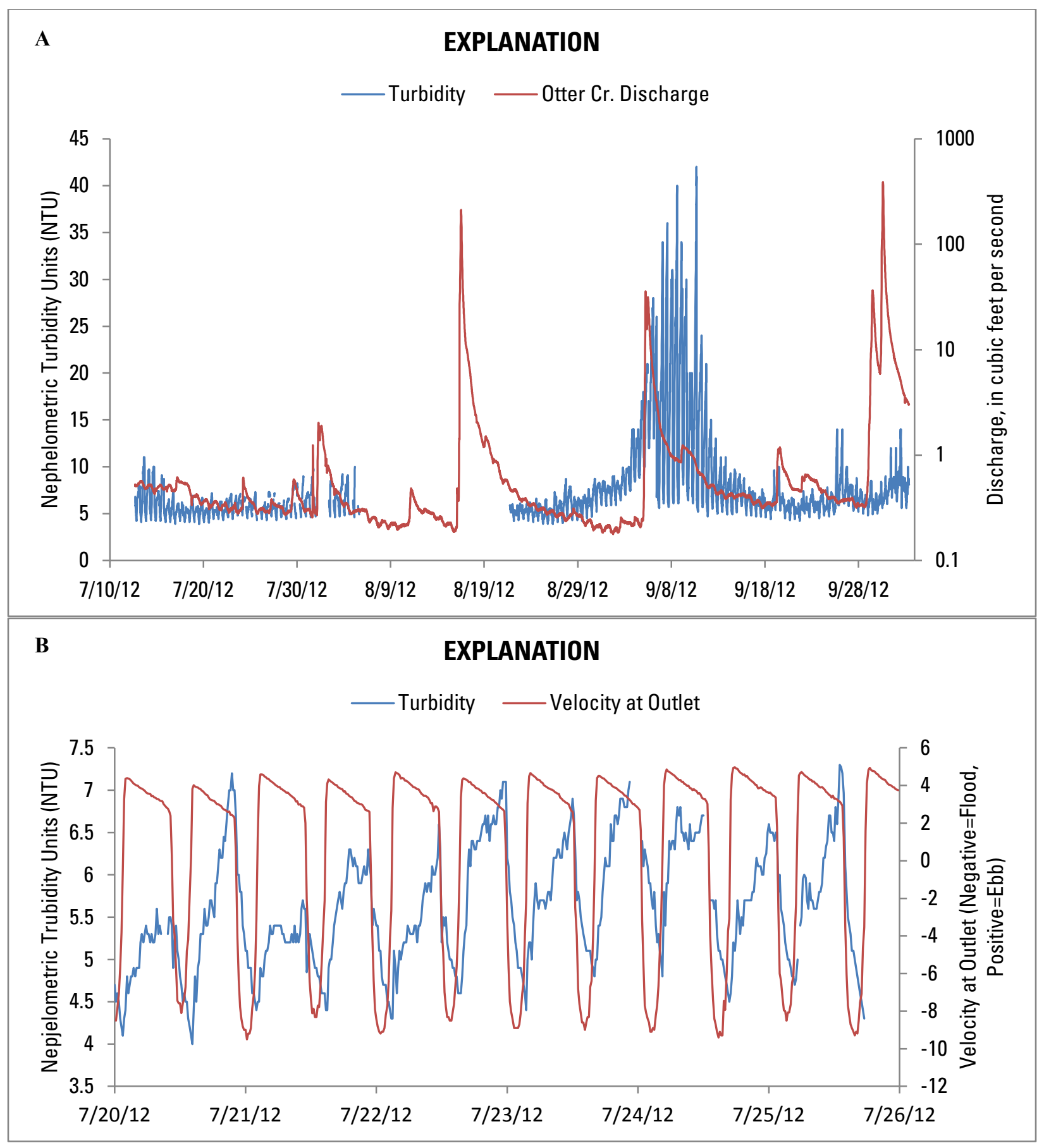

Figure 37. Graphs showing $A$, turbidity measured at the Bass Harbor Marsh estuary outlet and discharge measured at Otter Creek, Mount Desert Island, Maine, during 2012, and B, turbidity and flow velocity measured at the Bass Harbor Marsh estuary outlet. Positive velocity indicates ebb tide and negative velocity indicates flood tide. 


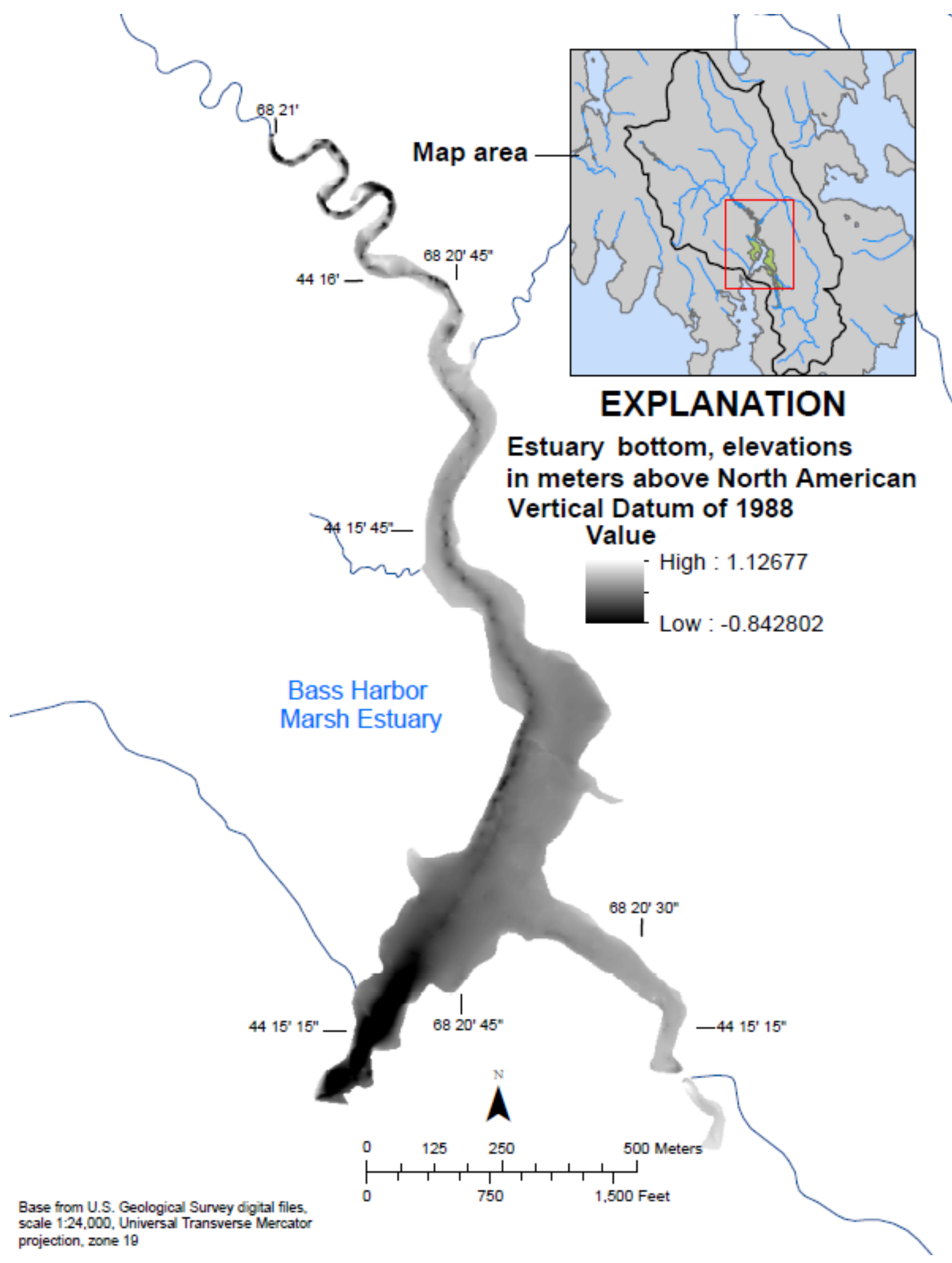

Figure 38. Bathymetric map showing Bass Harbor Marsh estuary, Mount Desert Island, Maine, at high tide at 14:01, July 7, 2012. 


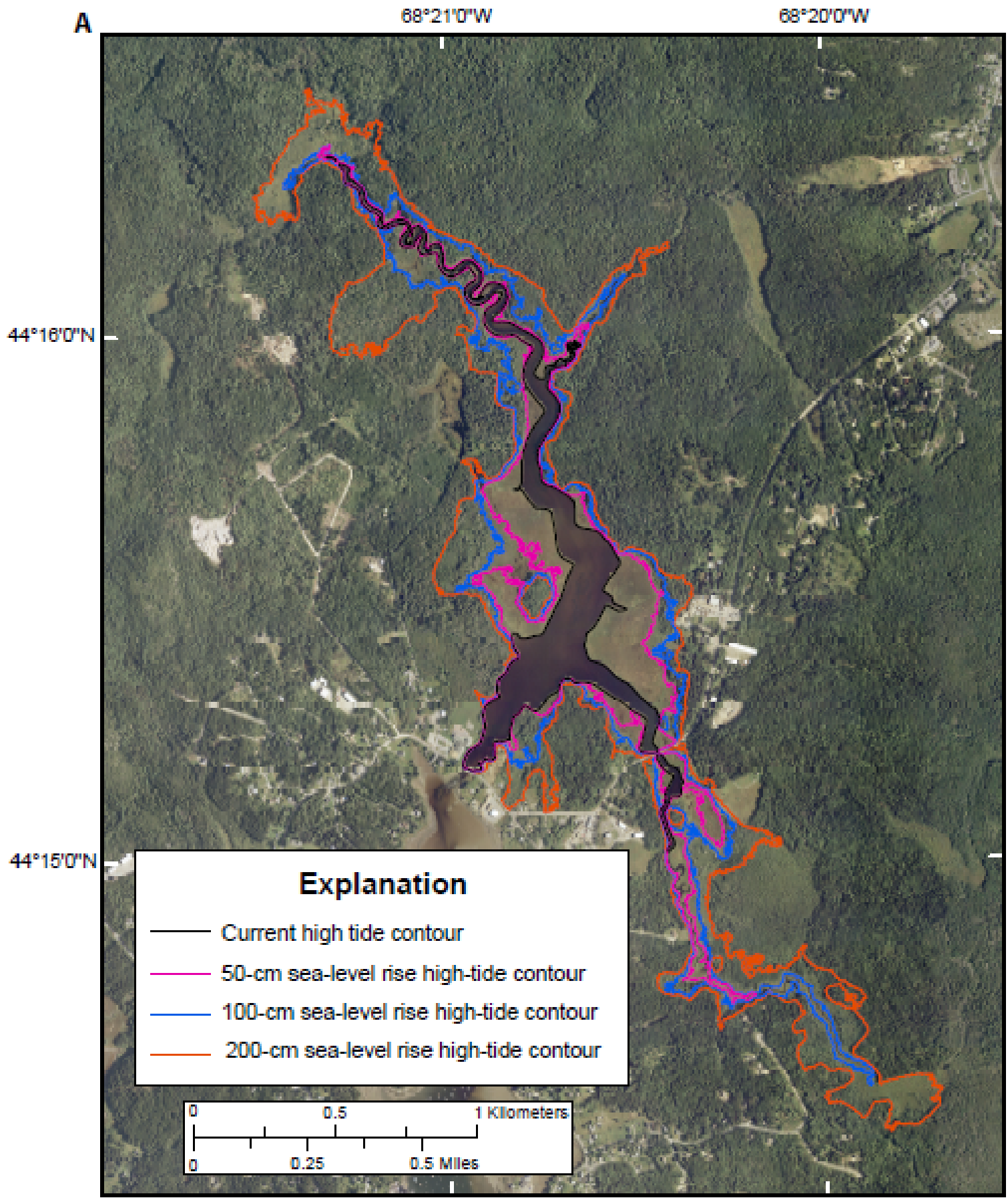

Base image credit: Maine Coastal Low Tide Ortho-rectified Digital Images, 2008. Maine Office of Geographic Information Systems (MEGIS).

Figure 39. Maps showing the predicted inundated areas within the Bass Harbor Marsh watershed, Mount Desert Island, Maine, at $A$, mean higher high water (MHHW) following 50-, 100-, and 200-centimeter (cm) sea-level rise (SLR), B, mean lower low water (MLLW) following 50-, 100-, and 200-cm SLR, and $C$, MHHW following 200-cm SLR with the 95-percent-upper- and lower-limit confidence bounds. The thick black line delineates the current [2013] channel boundary. 


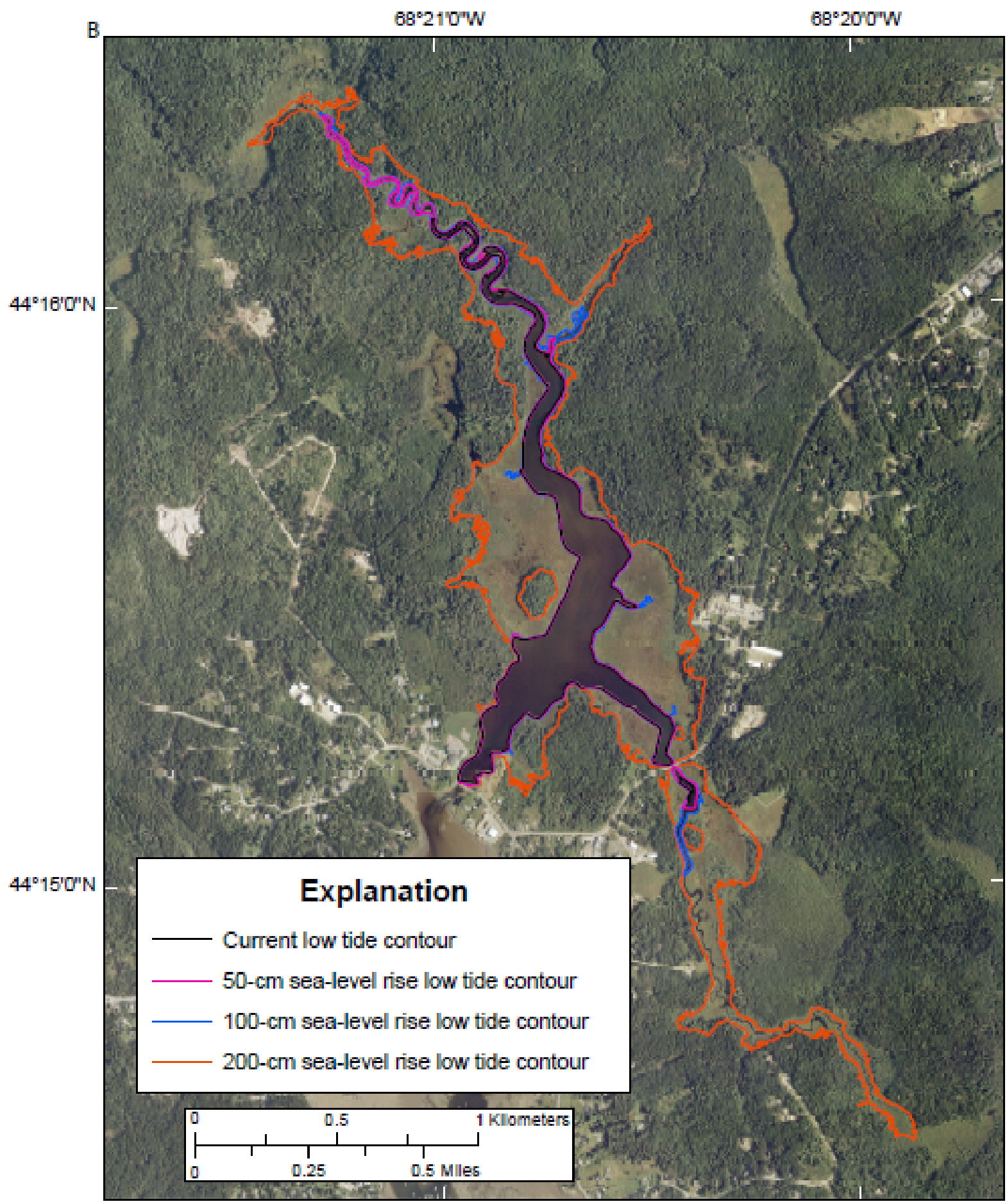

Base image credit: Maine Coastal Low Tide Ortho-rectified Digital Images, 2008. Maine Office of Geographic Information Systems (MEGIS).

Figure 39. Maps showing the predicted inundated areas within the Bass Harbor Marsh watershed, Mount Desert Island, Maine, at $A$, mean higher high water (MHHW) following 50-, 100-, and 200-centimeter (cm) sea-level rise (SLR), B, mean lower low water (MLLW) following 50-, 100-, and 200-cm SLR, and C, MHHW following 200-cm SLR with the 95-percent-upper- and lower-limit confidence bounds. The thick black line delineates the current [2013] channel boundary.-Continued 


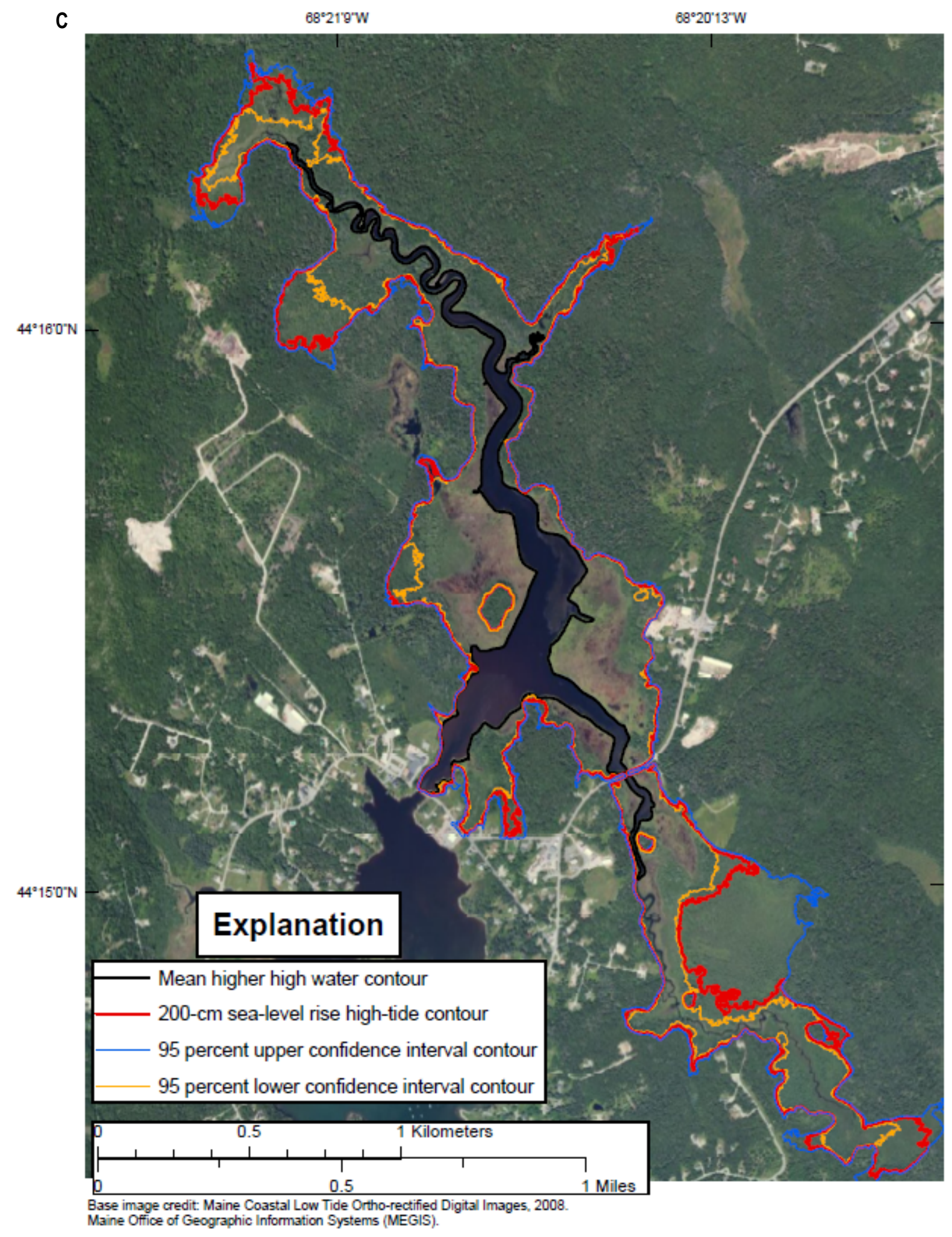

Figure 39. Maps showing the predicted inundated areas within the Bass Harbor Marsh watershed, Mount Desert Island, Maine, at $A$, mean higher high water (MHHW) following 50-, 100-, and 200-centimeter (cm) sea-level rise (SLR), B, mean lower low water (MLLW) following 50-, 100-, and 200-cm SLR, and C, MHHW following 200-cm SLR with the 95-percent-upper- and lower-limit confidence bounds. The thick black line delineates the current [2013] channel boundary.-Continued 


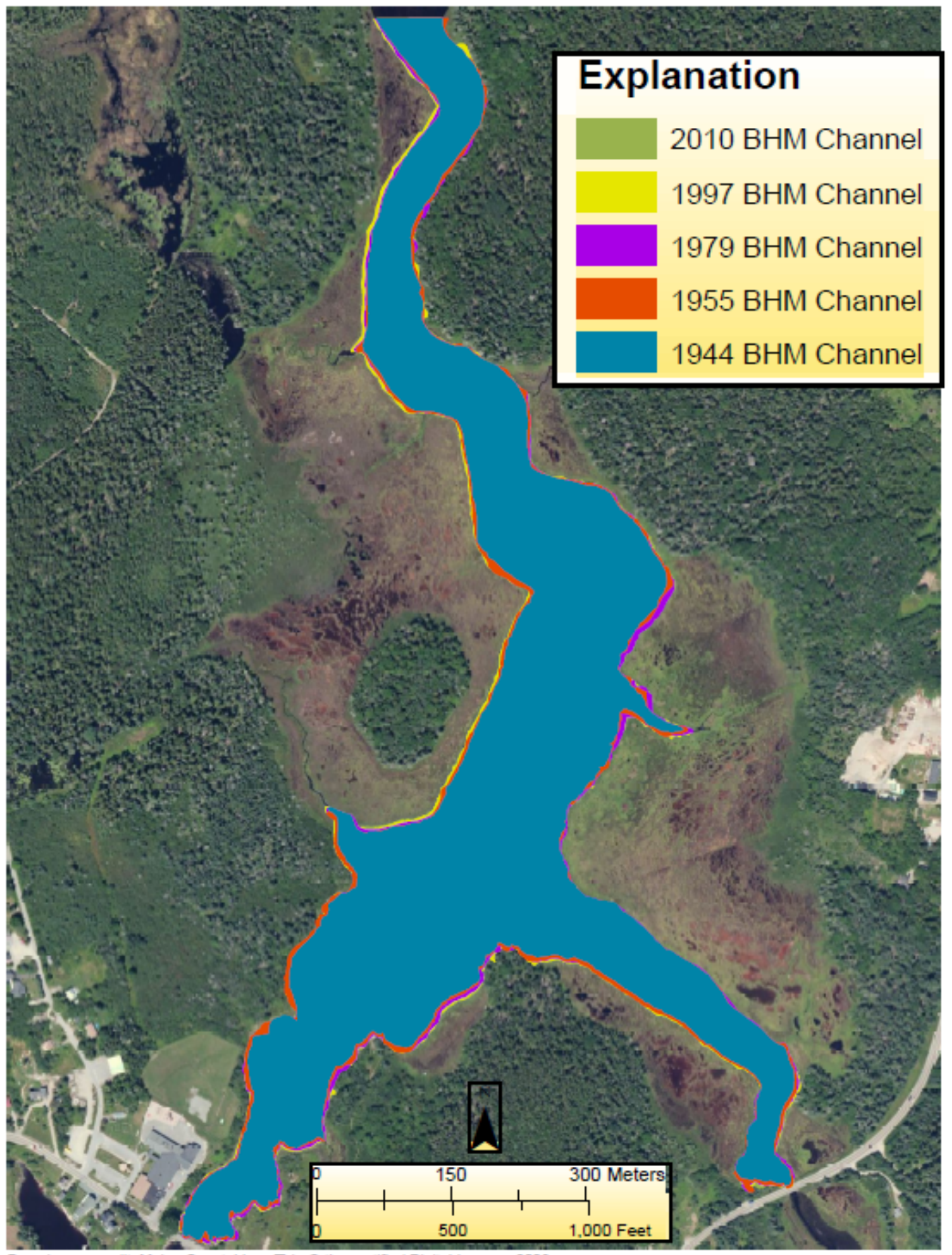

Base image credit: Maine Coastal Low Tide Ortho-rectified Digital Images, 2008. Maine Office of Geographic Information Systems (MEGIS).

Figure 40. Photograph showing Bass Harbor Marsh estuary channel delineation from historical georeferenced aerial photographs, Mount Desert Island, Maine. Colors indicate extent of the estuary channel in years shown. 

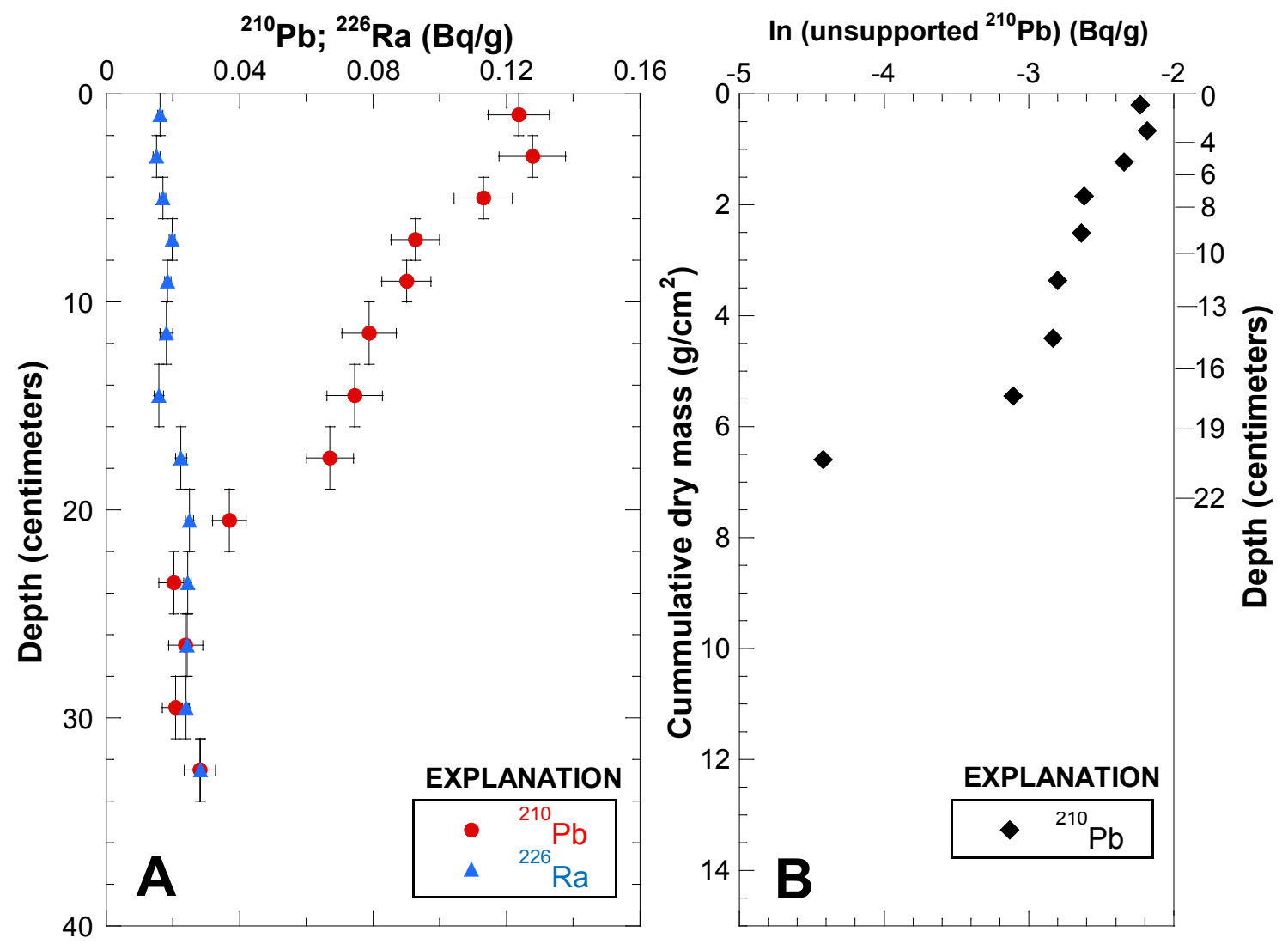

Figure 41. A, Graph showing total lead-210 $(210 \mathrm{~Pb})$ and radium-226 $(226 \mathrm{Ra})$ activities, in becquerels per gram $(\mathrm{Bq} / \mathrm{g})$, in relation to depth in sediment core BHM.01 from Bass Harbor Marsh, Mount Desert Island, Maine. The location of the sediment core is shown in figure 5. Horizontal error bars depict 1sigma uncertainty in the measured activity based on counting statistics. Vertical error bars depict depth range of sample interval. $B$, Graph showing natural logarithm of unsupported ${ }^{210} \mathrm{~Pb}$ activity in relation to cumulative dry sediment mass (grams per square centimeter) in sediment core BHM.01 from Bass Harbor Marsh, Mount Desert Island, Maine. The corresponding depth, in centimeters, is shown on right hand axis. 


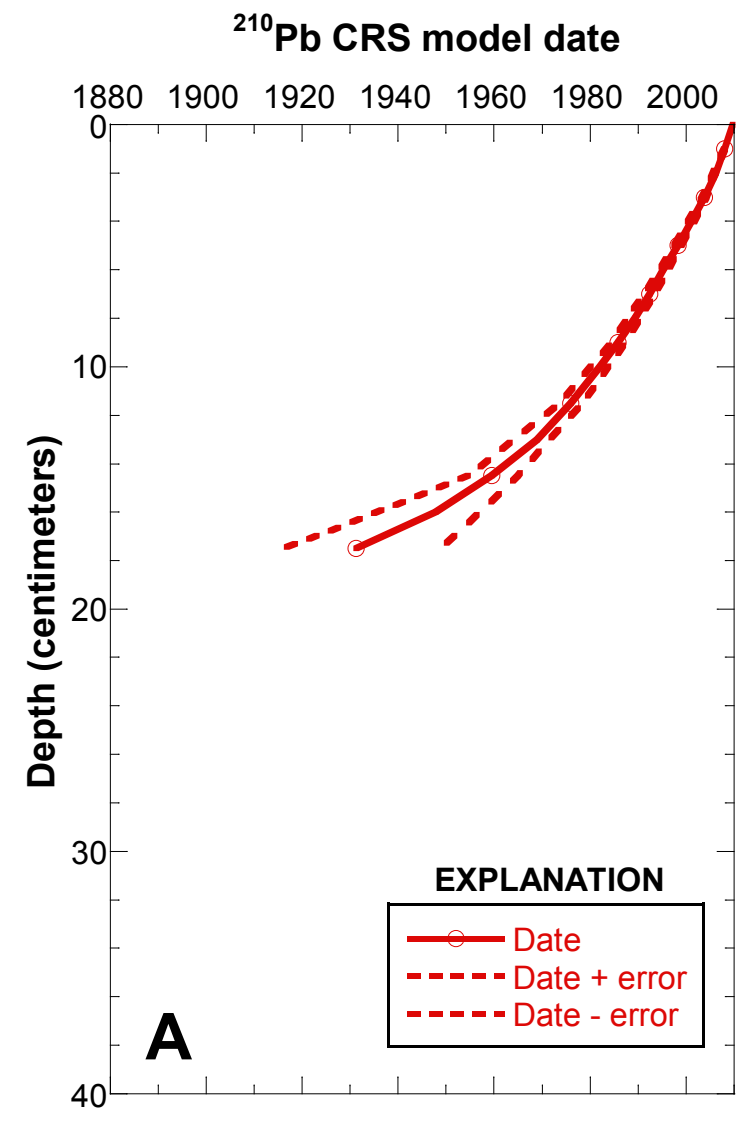

Sediment mass accumulation Rate (dry g/cm $/$ /yr) CRS model

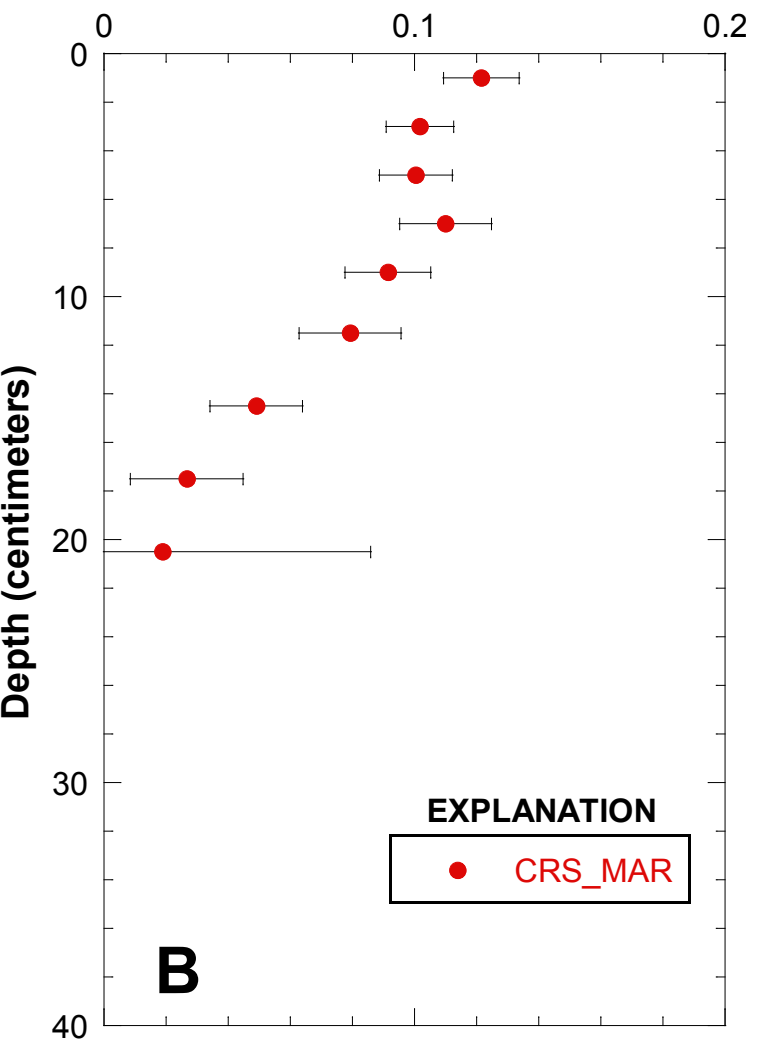

Figure 42. A, Graph showing sediment deposition date in relation to depth based on the sediment mass accumulation rate estimated from lead-210 $(210 \mathrm{~Pb})$ activity using the constant rate of supply (CRS) method in sediment core BHM.01 from Bass Harbor Marsh, Mount Desert Island, Maine. The location of the sediment core is shown in figure $5 . B$, Graph showing CRS method sediment mass accumulation rate (MAR), in grams of dry sediment per square centimeter per year, in relation to depth. Error bars represent 1-sigma propagated uncertainty in model MARs in sediment core BHM.01 from Bass Harbor Marsh, Mount Desert Island, Maine. 


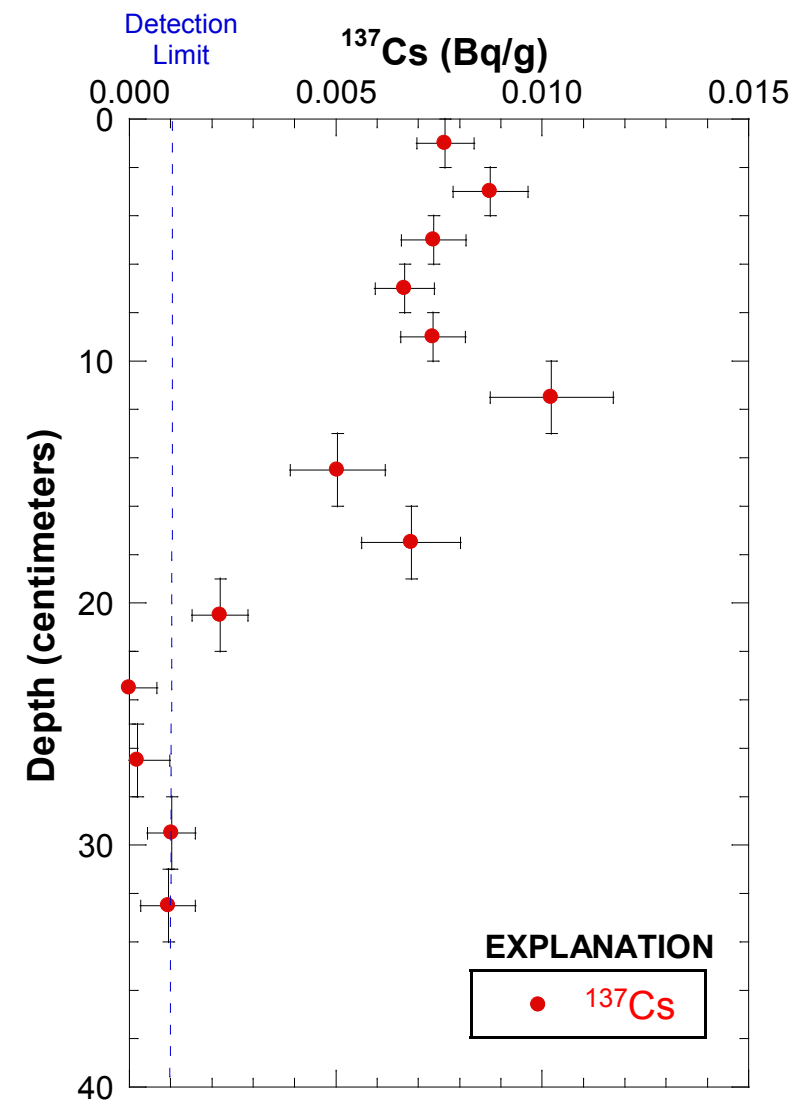

Figure 43. Graph showing cesium-137 $\left({ }^{137} \mathrm{Cs}\right)$ activity, in becquerels per gram, in relation to depth in sediment core BHM.01. The location of the sediment core is shown in figure 5 . Horizontal error bars depict 1-sigma uncertainty in measured activity based on counting statistics. Vertical error bars depict depth range of sample interval. Dashed line depicts method detection limit for ${ }^{137} \mathrm{Cs}$. 

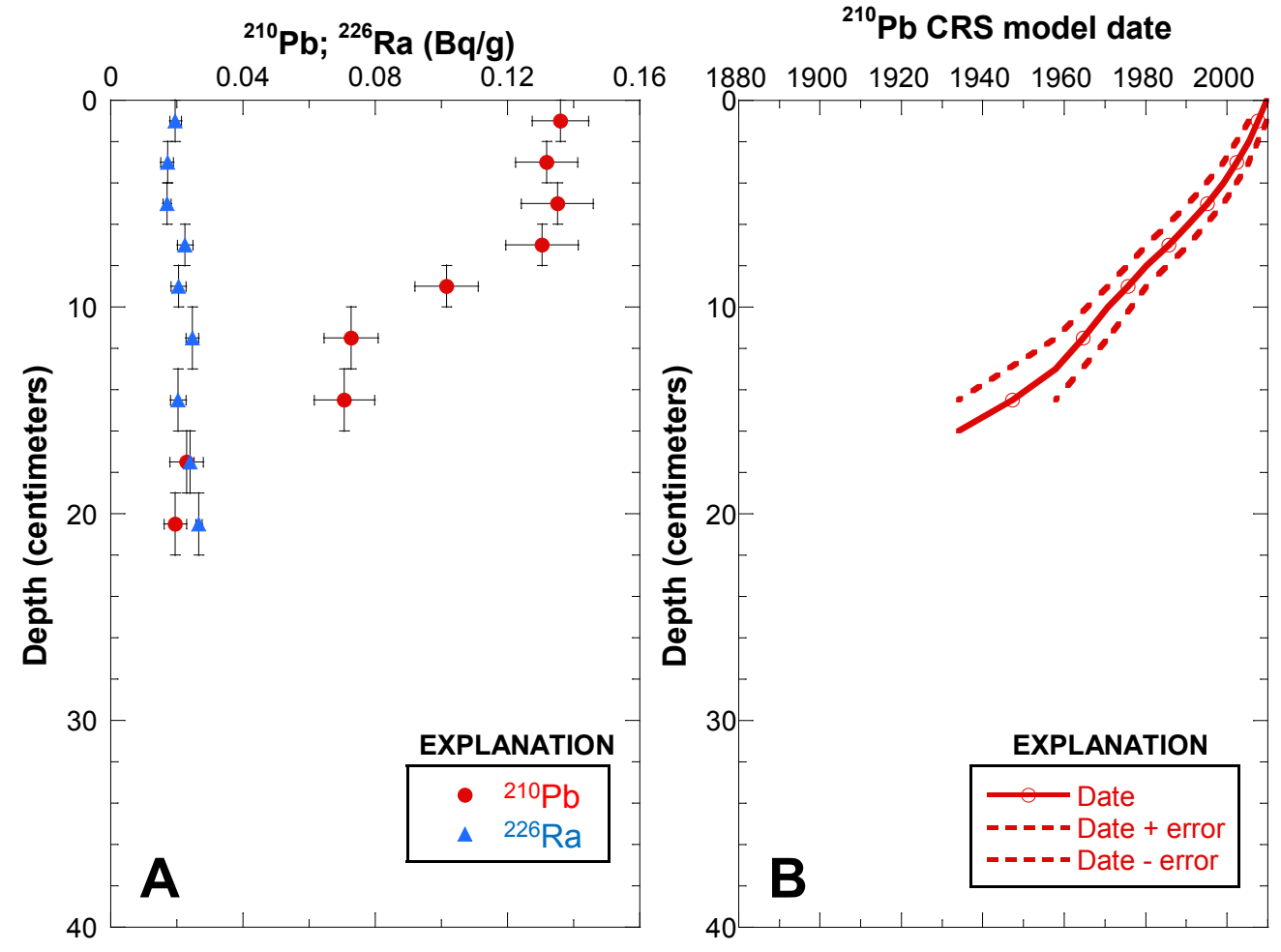

Figure 44. $A$, Graph showing total lead-210 $\left({ }^{210} \mathrm{~Pb}\right)$ and radium-226 $\left({ }^{226} \mathrm{Ra}\right)$ activities, in becquerels per gram (Bq/g), in relation to depth in sediment core BHM.02 from Bass Harbor Marsh, Mount Desert Island, Maine. The location of the sediment core is shown in figure 5. Horizontal error bars depict 1sigma uncertainty in measured activity based on counting statistics. Vertical error bars depict depth range of sample interval. $B$, Graph showing sediment deposition date in relation to depth based on the sediment mass accumulation rate estimated from ${ }^{210} \mathrm{~Pb}$ using the CRS (constant rate of supply) method in sediment core BHM.02 from Bass Harbor Marsh, Mount Desert Island, Maine. 


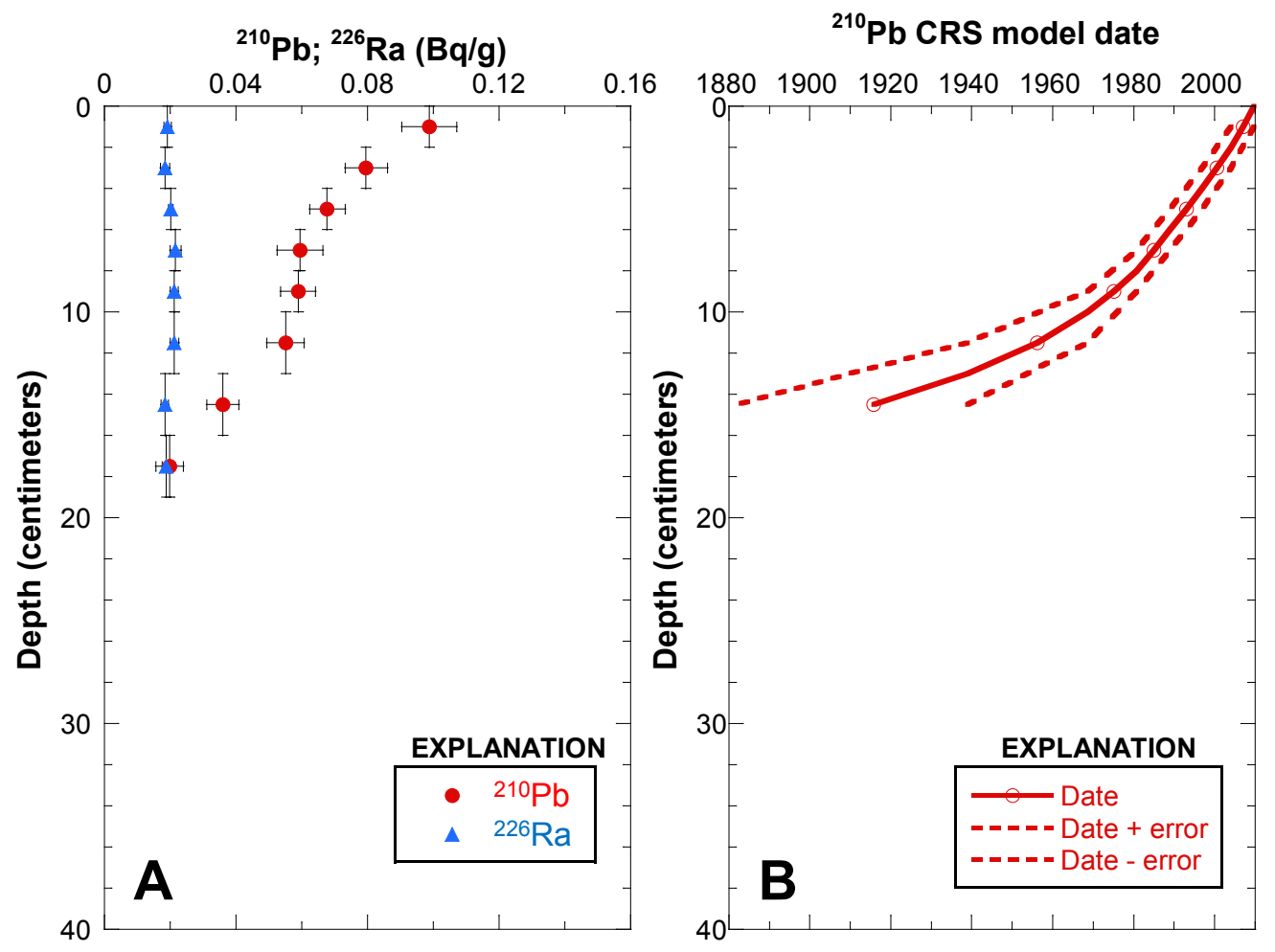

Figure 45. A, Graph showing total lead-210 $\left({ }^{210} \mathrm{~Pb}\right)$ and radium-226 $\left({ }^{226} \mathrm{Ra}\right)$ activities, in becquerels per gram $(\mathrm{Bq} / \mathrm{g})$, in relation to depth in sediment core BHM.03 from Bass Harbor Marsh, Mount Desert Island, Maine. The location of the sediment core is shown in figure 5. Horizontal error bars depict 1sigma uncertainty in measured activity based on counting statistics. Vertical error bars depict depth range of sample interval. $B$, Graph showing sediment deposition date in relation to depth based on the sediment mass accumulation rate estimated from ${ }^{210} \mathrm{~Pb}$ using the constant rate of supply (CRS) method in sediment core BHM.03 from Bass Harbor Marsh, Mount Desert Island, Maine. 


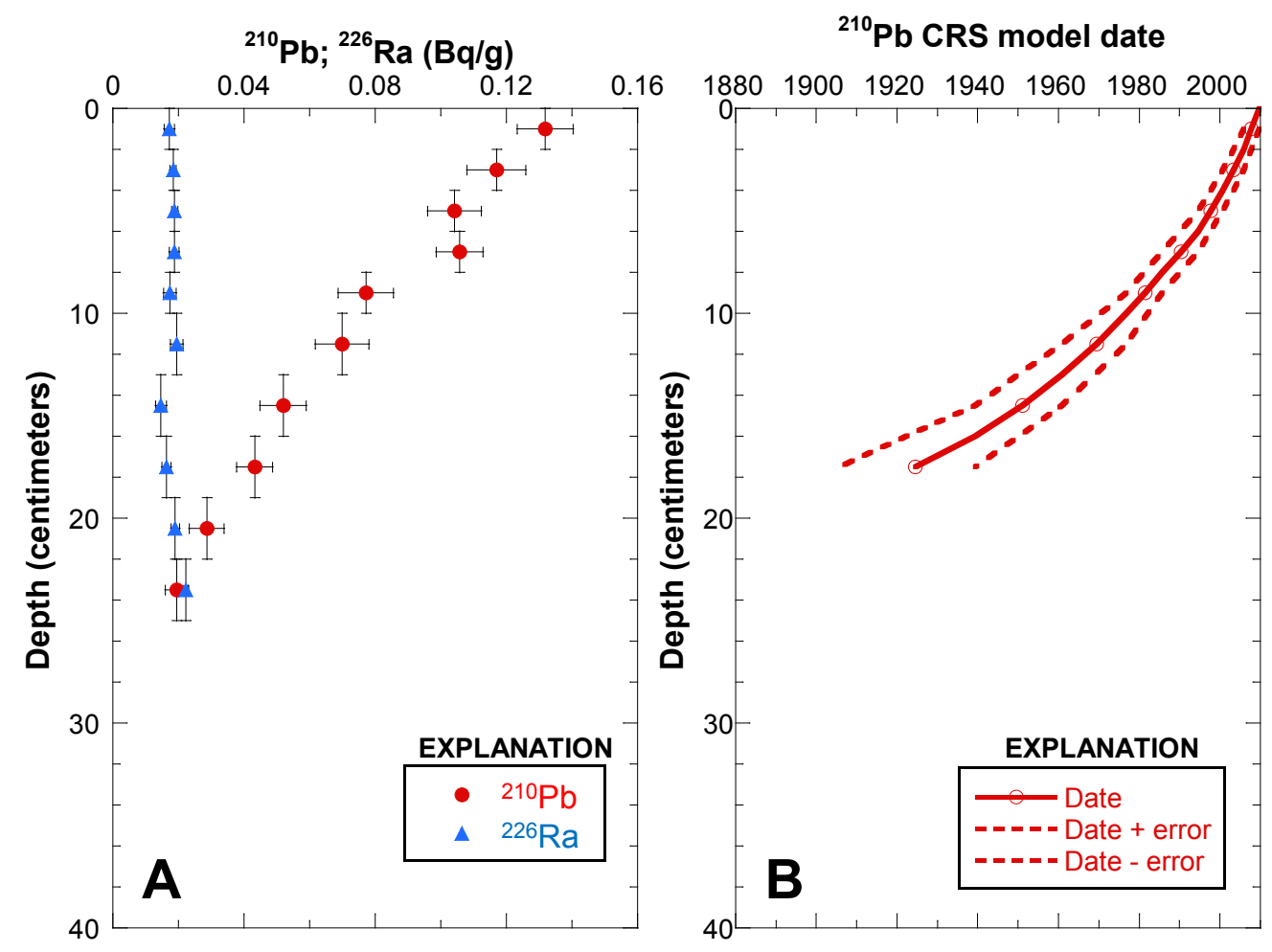

Figure 46. $\quad A$, Graph showing total lead-210 $\left({ }^{210} \mathrm{~Pb}\right)$ and radium-226 $\left({ }^{226} \mathrm{Ra}\right)$ activities, in becquerels per gram $(\mathrm{Bq} / \mathrm{g})$, in relation to depth in sediment core BHM.04 from Bass Harbor Marsh, Mount Desert Island, Maine. The location of the sediment core is shown in figure 5. Horizontal error bars depict 1sigma uncertainty in measured activity based on counting statistics. Vertical error bars depict depth range of sample interval. $B$, Graph showing sediment deposition date in relation to depth based on the sediment mass accumulation rate estimated from ${ }^{210} \mathrm{~Pb}$ using the constant rate of supply (CRS) method in sediment core BHM.04 from Bass Harbor Marsh, Mount Desert Island, Maine. 


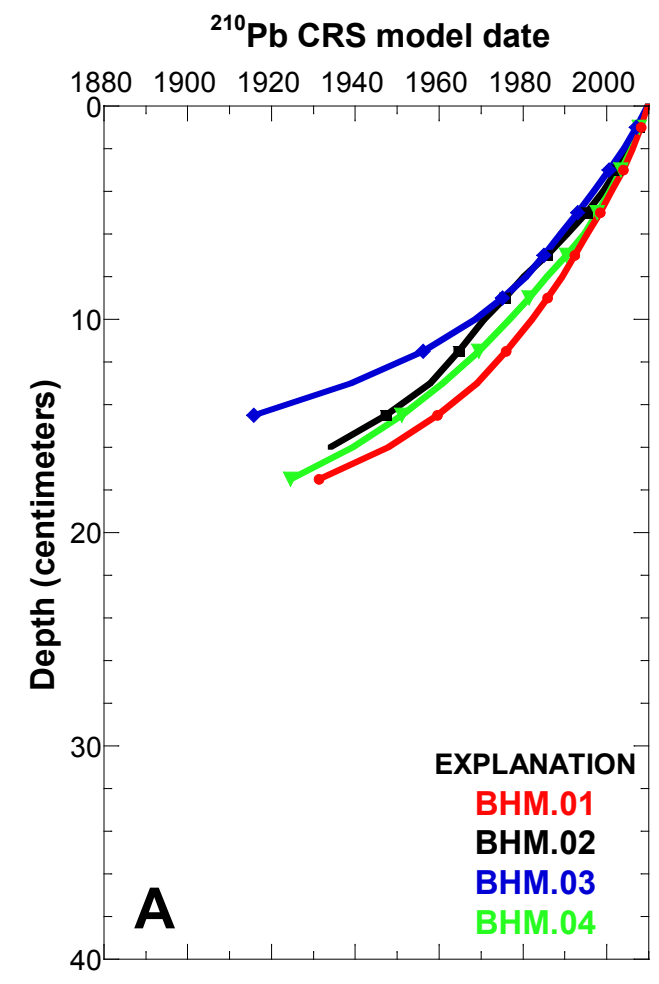

\section{Sediment mass accumulation rate}

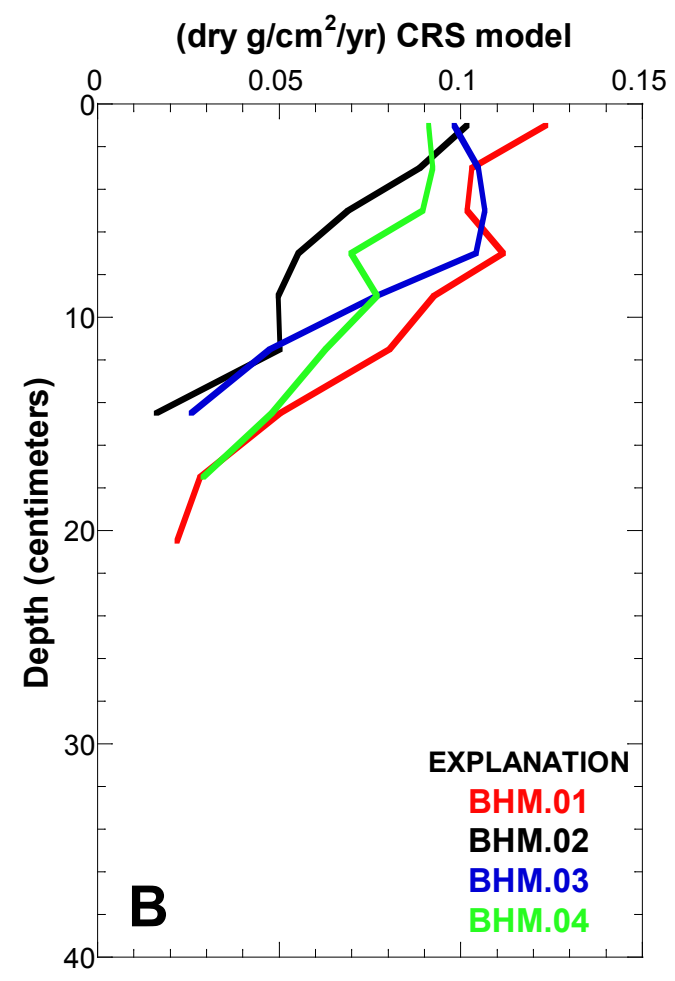

Figure 47. Graphs showing comparisons of $A$, lead-210 $(210 \mathrm{~Pb})$ constant rate of supply (CRS) dates in relation to depth at the four core sites within the Bass Harbor Marsh estuary, and $B$, mass accumulation rates from the CRS method in relation to depth at the four core sites within the Bass Harbor Marsh estuary, Mount Desert Island, Maine. 

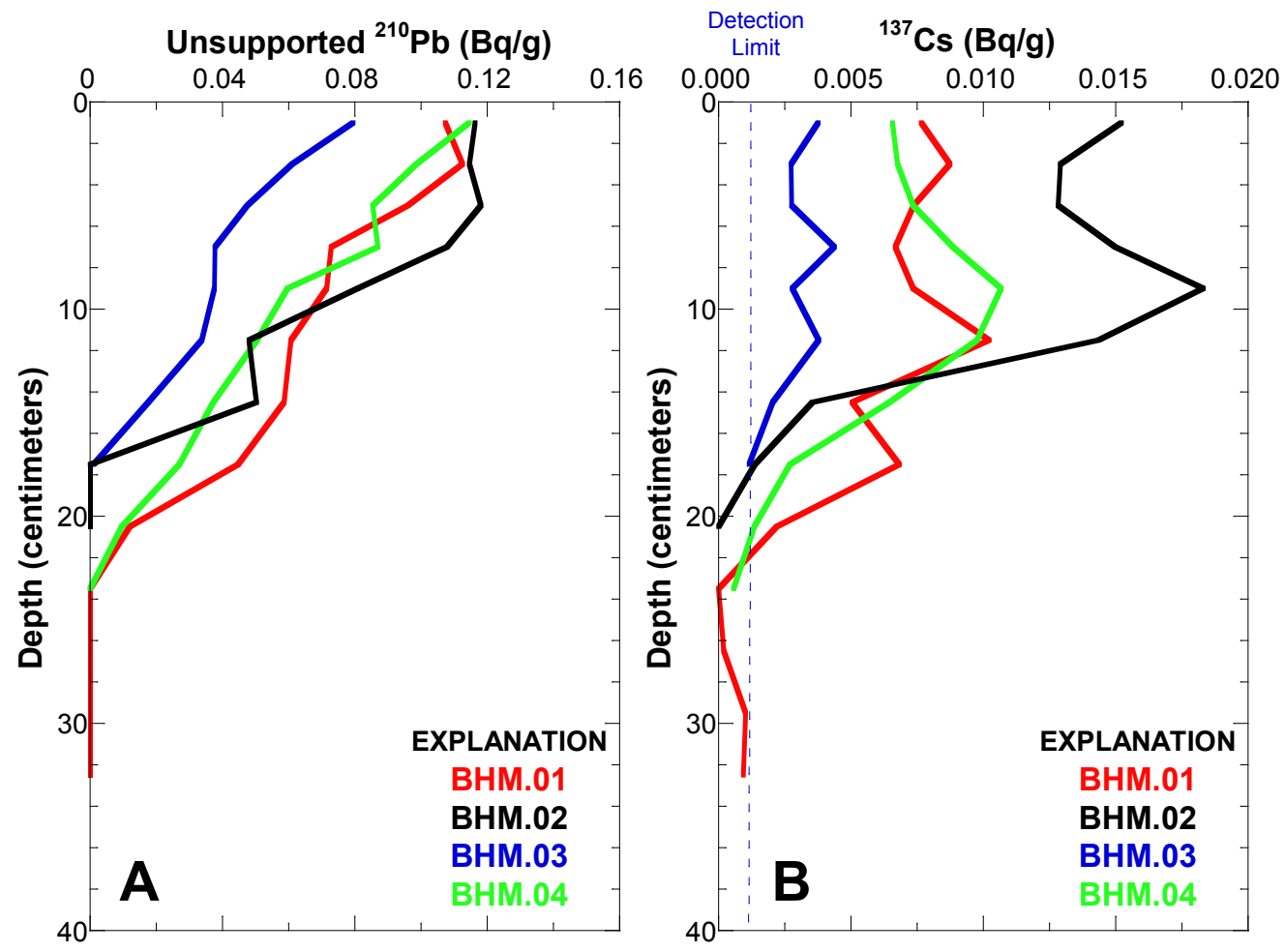

Figure 48. Graphs showing comparisons of $A$, unsupported lead-210 $(210 \mathrm{~Pb})$ activity, in becquerels per gram $(\mathrm{Bq} / \mathrm{g})$, in relation to depth at the four core sites within the Bass Harbor Marsh estuary, Mount Desert Island, Maine; and $B$, cesium $\left({ }^{137} \mathrm{Cs}\right)$ activity, in becquerels per gram $(\mathrm{Bq} / \mathrm{g})$, in relation to depth at the four core sites within the Bass Harbor Marsh estuary. Dashed line depicts method detection limit for ${ }^{137}$ Cs. 


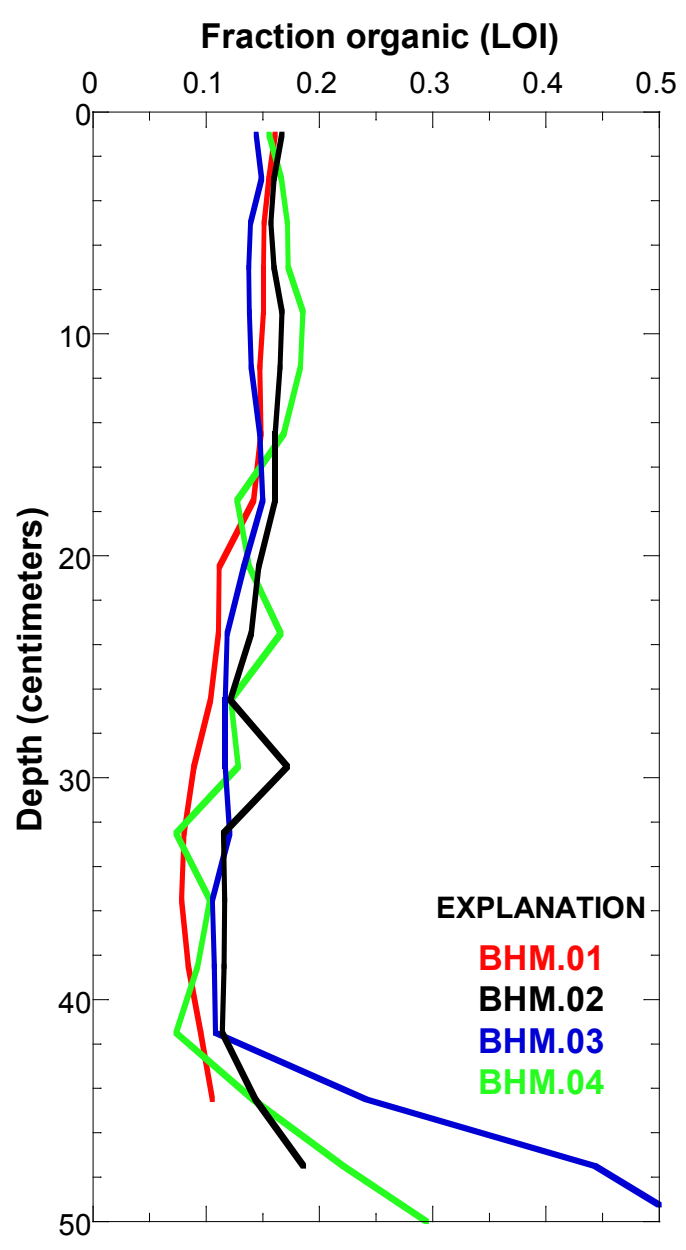

Figure 49. Graph showing organic matter content, expressed as the fraction of total dry sediment mass as determined from loss on ignition (LOI), in relation to depth for the four core sites within the Bass Harbor Marsh estuary, Mount Desert Island, Maine. 

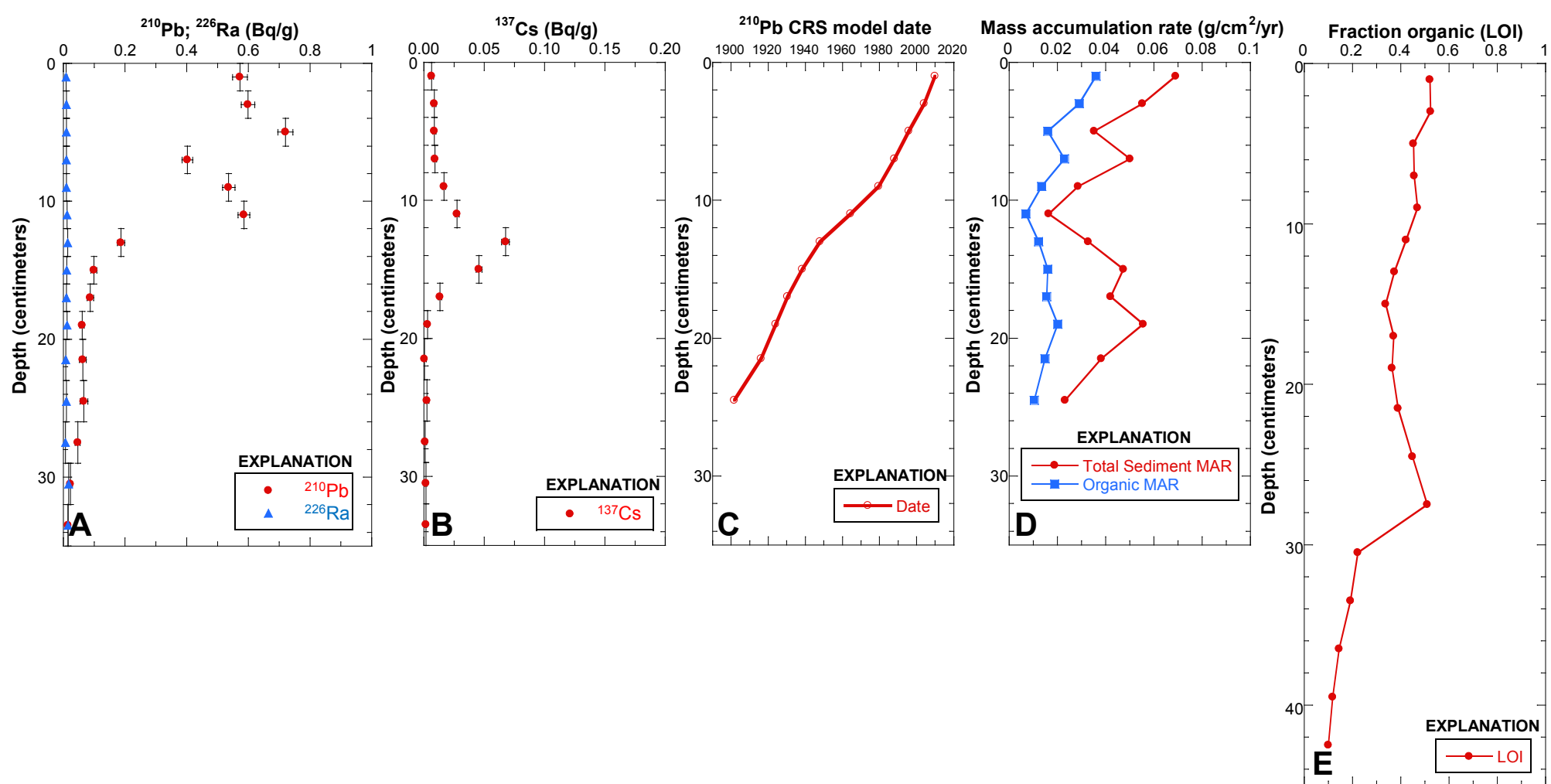

Figure 50. Graphs showing $A$, total lead-210 $(210 \mathrm{~Pb})$ and radium-226 $(226 \mathrm{Ra})$ activities, in becquerels per gram $(\mathrm{Bq} / \mathrm{g})$, in relation to depth in marsh surface sediment core BHM.S1 from Bass Harbor Marsh, Mount Desert Island, Maine (horizontal error bars depict 1-sigma uncertainty in measured activity based on counting statistics; vertical error bars depict depth range of sample interval); the location of the sediment core is shown in figure $5 ; B$, cesium-137 $\left({ }^{137} \mathrm{Cs}\right)$ activity, in becquerels per gram $(\mathrm{Bq} / \mathrm{g})$, in relation to depth; $C$, sediment deposition date in relation to depth based on the sediment mass accumulations estimated from ${ }^{210} \mathrm{~Pb}$ using the constant rate of supply (CRS) method; $D$, sediment mass accumulation rate (MAR), in grams of dry sediment per square centimeter per year $\left(\mathrm{g} / \mathrm{cm}^{2} / \mathrm{yr}\right)$, in relation to depth; and $E$, organic matter content, expressed as the fraction of total dry sediment mass as determined from loss on ignition (LOI), in relation to depth. 

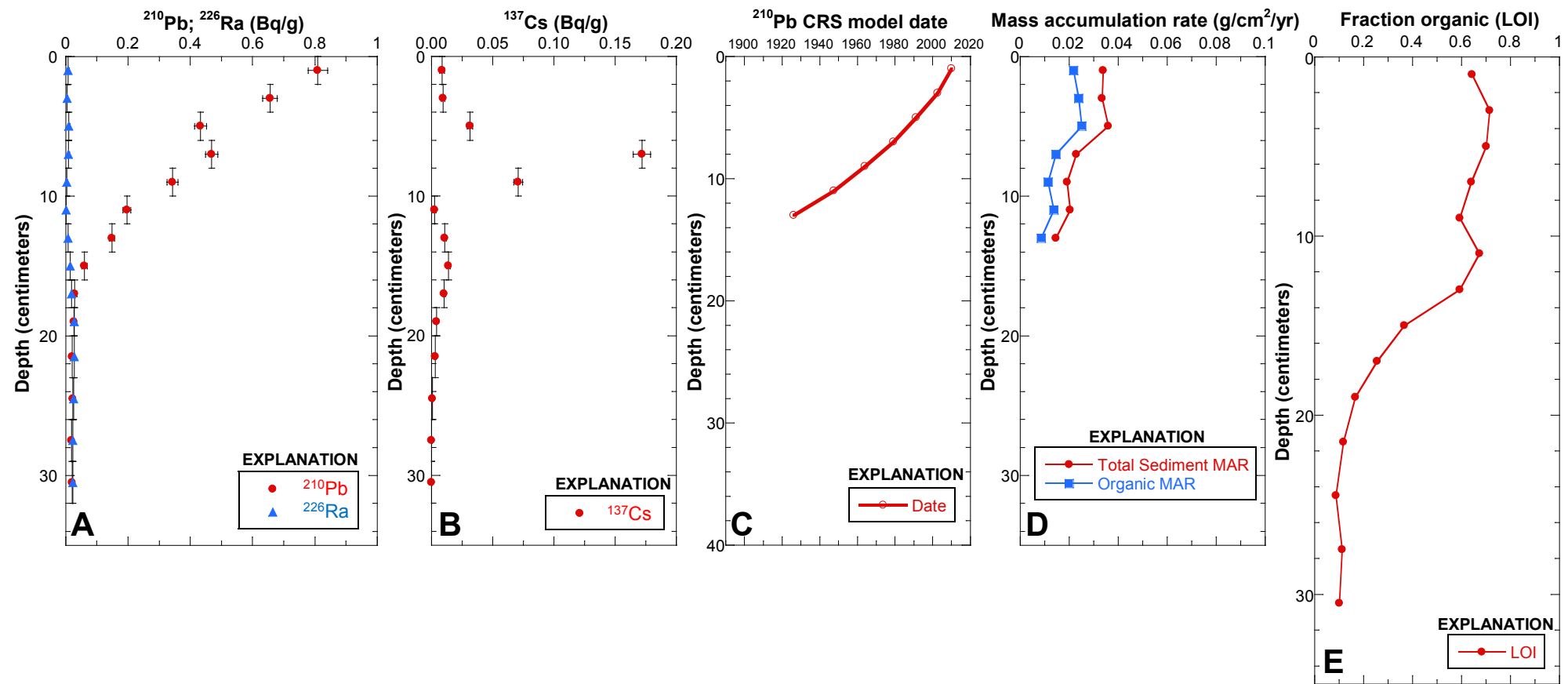

Figure 51. Graphs showing $A$, total lead-210 $(210 \mathrm{~Pb})$ and radium-226 $\left({ }^{226} \mathrm{Ra}\right)$ activities, in becquerels per gram $(\mathrm{Bq} / \mathrm{g})$, in relation to depth in marsh surface sediment core BHM.S2 from Bass Harbor Marsh, Mount Desert Island, Maine (horizontal error bars depict 1-sigma uncertainty in measured activity based on counting statistics; the location of the sediment core is shown in figure 5; vertical error bars depict depth range of sample interval); $B$, cesium-137 ( ${ }^{137} \mathrm{Cs}$ ) activity, in becquerels per gram (Bqi/g), in relation to depth. (C) Sediment deposition date in relation to depth based on the sediment mass accumulations estimated from ${ }^{210} \mathrm{~Pb}$ using the constant rate of supply (CRS) method. (D) Sediment mass accumulation rate (MAR), in grams of dry sediment per square centimeter per year $\left(\mathrm{g} / \mathrm{cm}^{2} / \mathrm{yr}\right)$, in relation to depth. (E) Organic matter content, expressed as the fraction of total dry sediment mass as determined from loss on ignition (LOI), in relation to depth. 

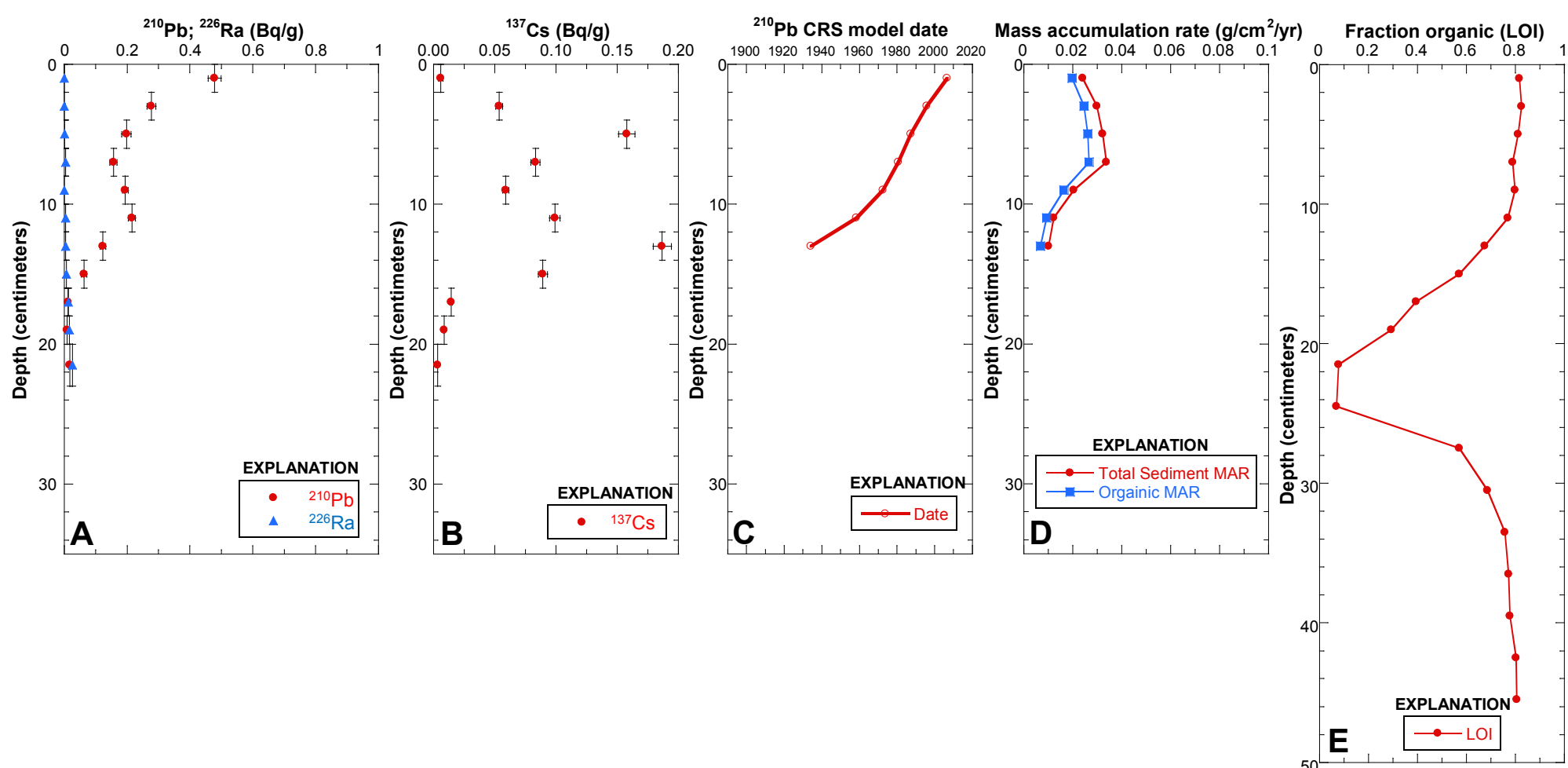

Figure 52. Graphs showing A, Total lead-210 $(210 \mathrm{~Pb})$ and radium-226 $(226 \mathrm{Ra})$ activities, in becquerels per gram $(\mathrm{Bq} / \mathrm{g})$, in relation to depth in marsh surface sediment core BHM.S3. The location of the sediment core is shown in figure 5 . Horizontal error bars depict 1-sigma uncertainty in measured activity based on counting statistics. Vertical error bars depict depth range of sample interval. $B,{ }^{137} \mathrm{Cs}$ activity, in becquerels per gram $(\mathrm{Bq} / \mathrm{g})$, in relation to depth. $\mathrm{C}$, Sediment deposition date in relation to depth based on the sediment mass accumulations estimated from ${ }^{210} \mathrm{~Pb}$ using the constant rate of supply (CRS) method. $D$, Sediment mass accumulation rate (MAR), in grams of dry sediment per square centimeter per year $\left(\mathrm{g} / \mathrm{cm}^{2} / \mathrm{yr}\right)$, in relation to depth. $E$, Organic matter content, expressed as the fraction of total dry sediment mass as determined from loss on ignition (LOI), in relation to depth. 

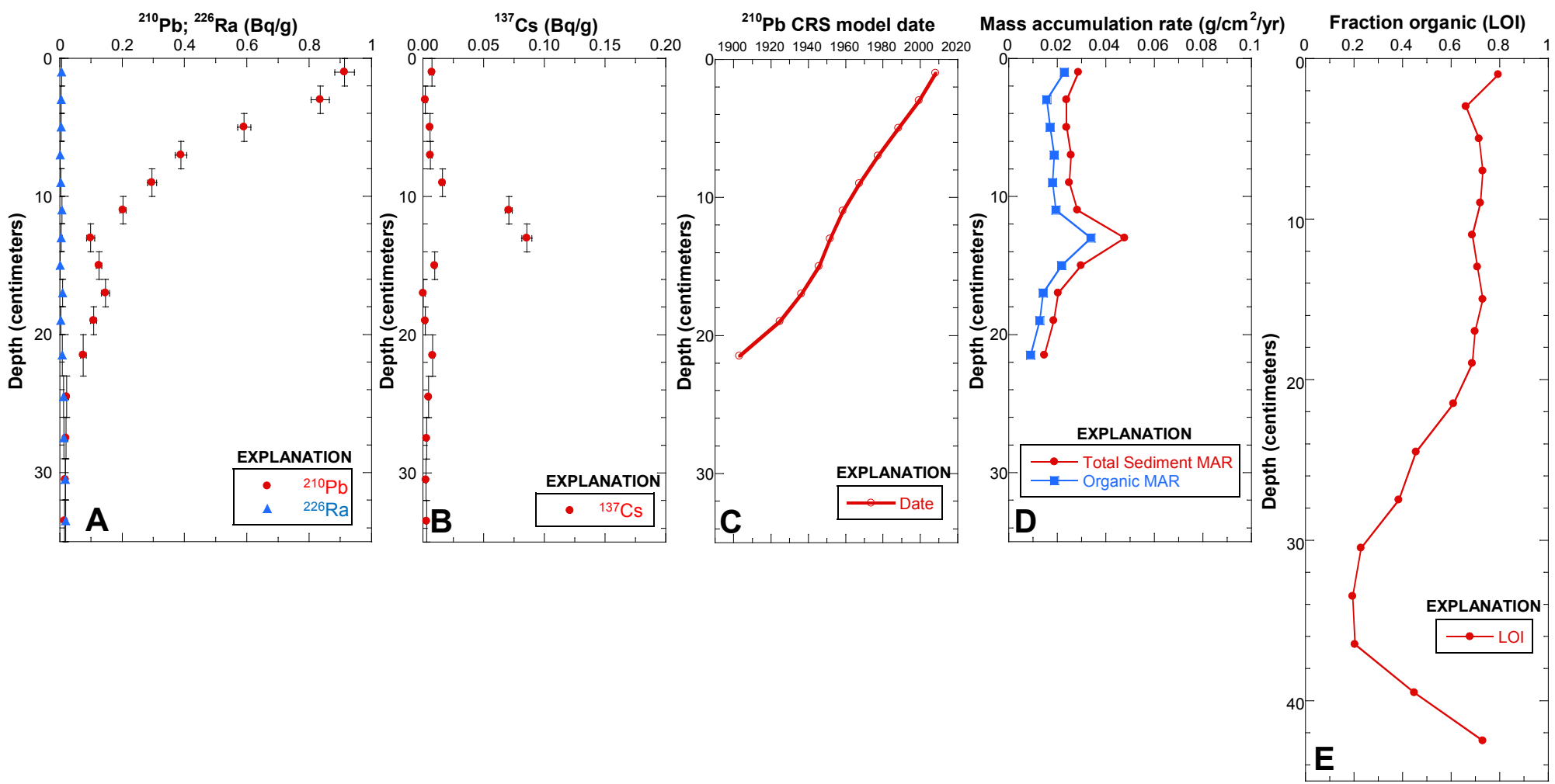

Figure 53. Graphs showing $(A)$ Total lead-210 $\left({ }^{210} \mathrm{~Pb}\right)$ and radium-226 $\left({ }^{226} \mathrm{Ra}\right)$ activities, in becquerels per gram (Bq/g), in relation to depth in marsh surface sediment core BHM.S4a. The location of the sediment core is shown in figure 5. Horizontal error bars depict 1-sigma uncertainty in measured activity based on counting statistics. Vertical error bars depict depth range of sample interval. (B) ${ }^{137} \mathrm{Cs}$ activity, in becquerels per gram $(\mathrm{Bq} / \mathrm{g})$, in relation to depth. (C) Sediment deposition date in relation to depth based on the sediment mass accumulations estimated from ${ }^{210} \mathrm{~Pb}$ using the constant rate of supply (CRS) method. (D) Sediment mass accumulation rate (MAR), in grams of dry sediment per square centimeter per year $\left(\mathrm{g} / \mathrm{cm}^{2} / \mathrm{yr}\right)$, in relation to depth. (E) Organic matter content, expressed as the fraction of total dry sediment mass as determined from loss on ignition (LOI), in relation to depth. 

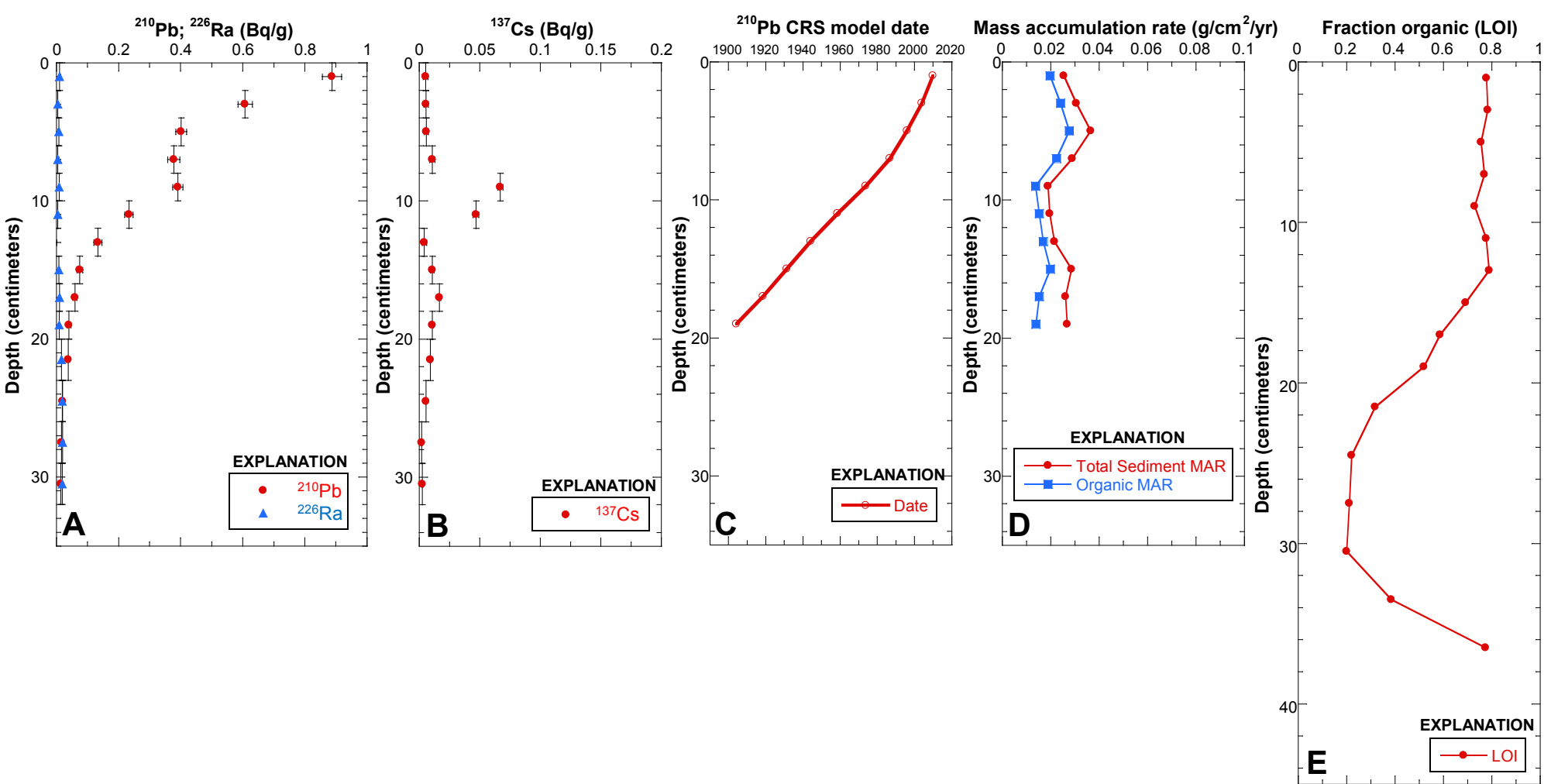

Figure 54. Graphs showing $(\mathrm{A})$ lead-210 $(210 \mathrm{~Pb}) 210 \mathrm{~Pb}$ and radium-226 $(226 \mathrm{Ra})$ activities, in becquerels per gram $(\mathrm{Bq} / \mathrm{g})$, in relation to depth in marsh surface sediment core BHM.S4b. The location of the sediment core is shown in figure 5. Horizontal error bars depict 1-sigma uncertainty in measured activity based on counting statistics. Vertical error bars depict depth range of sample interval. (B) 137Cs activity, in becquerels per gram $(\mathrm{Bq} / \mathrm{g})$, in relation to depth. (C) Sediment deposition date in relation to depth based on the sediment mass accumulations estimated from $210 \mathrm{~Pb}$ using the constant rate of supply (CRS) method. (D) Sediment mass accumulation rate (MAR), in grams of dry sediment per square centimeter per year $(\mathrm{g} / \mathrm{cm} 2 / \mathrm{yr})$, in relation to depth. (E) Organic matter content, expressed as the fraction of total dry sediment mass as determined from loss on ignition (LOI), in relation to depth. 


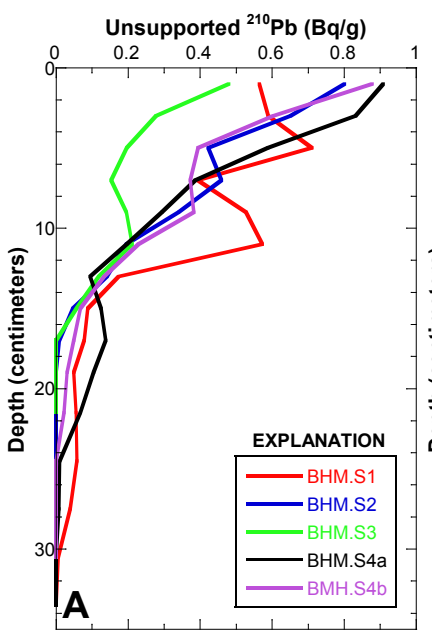

Total sediment MAR $\left(\mathrm{g} / \mathrm{cm}^{2} / \mathrm{yr}\right)$

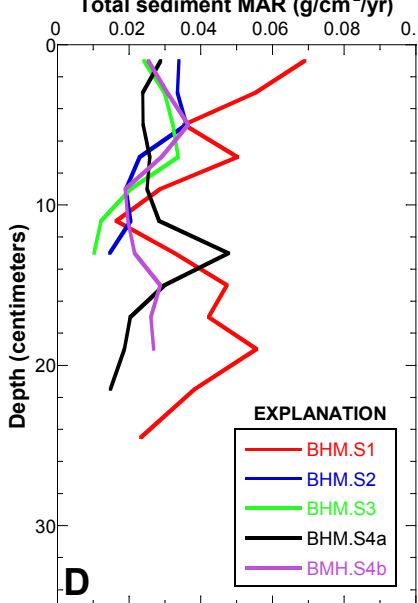

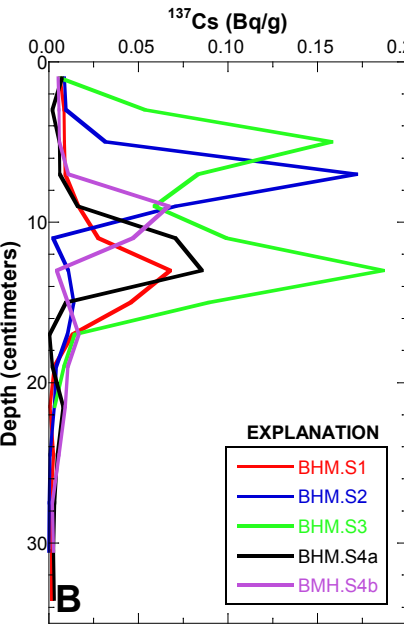

Organic sediment MAR $\left(\mathrm{g} / \mathrm{cm}^{2} / \mathrm{yr}\right)$

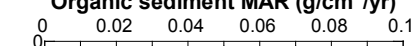

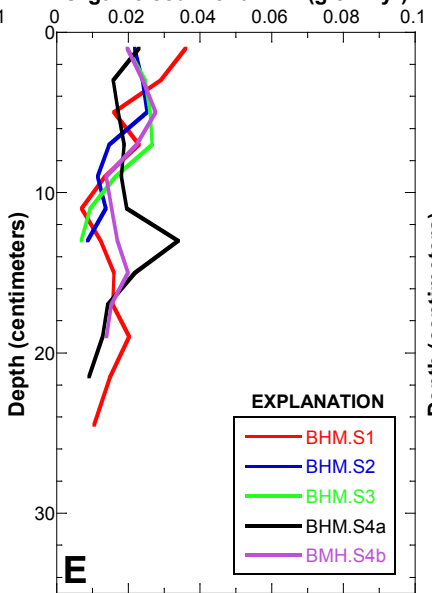

${ }^{210} \mathrm{~Pb}$ CRS model date

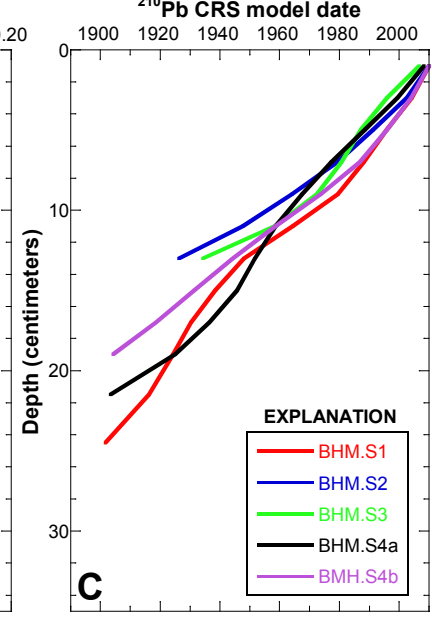

Inorganic sediment MAR (g/cm $/ \mathrm{lyr})$

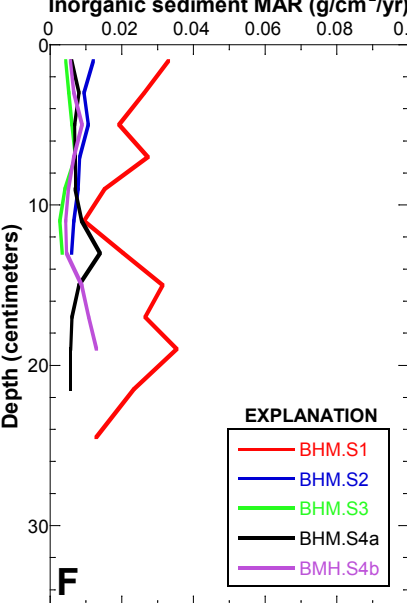

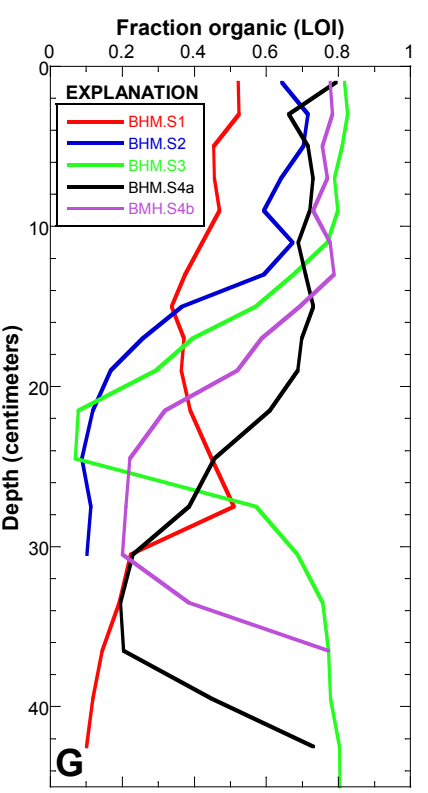

Figure 55. Graphs showing $(A)$ Unsupported lead-210 (210 Pb) activity, in becquerels per gram $(\mathrm{Bq} / \mathrm{g})$, in relation to depth, in centimeters $(\mathrm{cm})$, in the five marsh surface sediment cores. (B) Cesium-137 ( $\left.{ }^{137} \mathrm{Cs}\right)$ activity, in becquerels per gram $(\mathrm{Bq} / \mathrm{g})$, in relation to depth; $C$, sediment deposition date in relation to depth based on the sediment mass accumulations estimated from ${ }^{210 \mathrm{~Pb}}$ using the CRS (constant rate of supply) method; $D$, sediment mass accumulation rate (MAR), in grams of dry sediment per square centimeter per year in relation to year $\left(\mathrm{g} / \mathrm{cm}^{2} / \mathrm{yr}\right) ; E$, organic matter MAR in relation to depth; $F$, inorganic sediment mass accumulation rate in relation to depth; and $G$, organic matter content, expressed as the fraction of total dry sediment mass as determined from loss on ignition (LOI), in relation to depth. 
Table 1. Surface-water-streamgaging and water-quality-monitoring stations in Bass Harbor Marsh watershed in Mount Desert Island, Maine. [Sites were sampled in 2011 and 2012 for this study and in 2008 and 2009 for the study published in Huntington and others (2012). Latitude and longitude determined with Global Positioning System ( $\pm 2-5$ meters); figure 2 shows site locations. BHM, Bass Harbor Marsh; km², square kilometers; $\mathrm{n} / \mathrm{a}$, not available; $\mathrm{NH}_{4}$, ammonium; $\mathrm{NO}_{3}$, nitrate; TDN, total dissolved nitrogen; TDP, total dissolved phosphorus; USGS, U.S. Geological Survey; ${ }^{\circ}$, degrees; ', minutes; ", seconds]

\begin{tabular}{|c|c|c|c|c|}
\hline Site name & $\begin{array}{c}\text { USGS } \\
\text { streamgage } \\
\text { identification } \\
\text { number }\end{array}$ & $\begin{array}{l}\text { Latitude and } \\
\text { longitude }\end{array}$ & $\begin{array}{l}\text { Drainage area1 } \\
\qquad\left(\mathrm{km}^{2}\right)\end{array}$ & $\begin{array}{c}\text { Number of samples (TDN, } \\
\mathrm{NO}_{3}, \mathrm{NH}_{4}, \mathrm{TDP} \text { ) }\end{array}$ \\
\hline Marshall Brook near & 01022890 & $44^{\circ} 16^{\prime} 29.0^{\prime \prime}$ & $5.10(6.52)$ & $20,16,16,20$ \\
\hline Southwest Harbor, Maine & & $68^{\circ} 21^{\prime} 05.0^{\prime \prime}$ & & \\
\hline Lurvey Brook ${ }^{2}$ near & 01022892 & $44^{\circ} 16^{\prime} 44.0^{\prime \prime}$ & $0.315(\mathrm{n} / \mathrm{a})$ & $22,15,15,22$ \\
\hline Southwest Harbor, Maine & & $68^{\circ} 21^{\prime} 28.0^{\prime \prime}$ & & \\
\hline $\begin{array}{l}\text { Heath Brook near Tremont, } \\
\text { Maine }\end{array}$ & 01022895 & $\begin{array}{l}44^{\circ} 16^{\prime} 40.0^{\prime \prime} \\
68^{\circ} 22^{\prime} 05.0^{\prime \prime}\end{array}$ & $2.33(2.93)$ & $23,17,17,23$ \\
\hline Adams Brook, near & $\mathrm{n} / \mathrm{a}$ & $44^{\circ} 14^{\prime} 37.4^{\prime \prime}$ & $4.14(5.01)$ & $8,8,8,8$ \\
\hline Tremont, Maine & & $68^{\circ} 19^{\prime} 58.3^{\prime \prime}$ & & \\
\hline $\begin{array}{l}\text { BHM watershed, Estuary } \\
\text { outlet }\end{array}$ & 010228955 & $\begin{array}{l}44^{\circ} 15^{\prime} 10.5^{\prime \prime} \\
68^{\circ} 20^{\prime} 57.1^{\prime \prime}\end{array}$ & 22.00 & $\begin{array}{l}\text { Ebb tide: } 134,97,99,134 \\
\text { Flood tide: } 73,68,68,74\end{array}$ \\
\hline Estuary (open water) & $\mathrm{n} / \mathrm{a}$ & $\mathrm{n} / \mathrm{a}$ & 0.243 & $\mathrm{n} / \mathrm{a}$ \\
\hline Ungaged area & $\mathrm{n} / \mathrm{a}$ & $\mathrm{n} / \mathrm{a}$ & 9.865 & $\mathrm{n} / \mathrm{a}$ \\
\hline
\end{tabular}

${ }^{1}$ Drainage area at the sampling and discharge-measurement location. The area in parentheses is the area of the sub-watershed at the confluence with the estuary.

${ }^{2}$ Lurvey Brook flows into Heath Brook before Heath Brook flows into the estuary. 
Table 2. Constituents and minimum reporting limits for water-quality-sample analyses conducted as part of this study.

[USGS, U.S. Geological Survey; NWIS, National Water Information System; $\mathrm{km}^{2}$, square kilometers; LED, lightemitting diode; mg/L, milligrams per liter; $\mathrm{N}$, nitrogen; $\mathrm{P}$, phosphorus; $\mu \mathrm{S} / \mathrm{cm}$, microsiemens per centimeter; ${ }^{\circ} \mathrm{C}$, degrees Celsius; ${ }^{\circ}$, degrees]

\begin{tabular}{llc}
\hline $\begin{array}{c}\text { USGS } \\
\text { parameter code }\end{array}$ & \multicolumn{1}{c}{$\begin{array}{c}\text { NWIS constituent } \\
\text { (units) }\end{array}$} & $\begin{array}{c}\text { Minimum } \\
\text { reporting limit }\end{array}$ \\
\hline 62854 & Nitrogen, total $(\mathrm{mg} / \mathrm{L}$ as N) & 0.006 \\
00665 & Phosphorus, total $(\mathrm{mg} / \mathrm{L}$ as $\mathrm{P})$ & 0.002 \\
00618 & Nitrogen, nitrate, dissolved $(\mathrm{mg} / \mathrm{L} \mathrm{as} \mathrm{N)}$ & 0.0007 \\
00608 & Nitrogen, ammonia, dissolved $(\mathrm{mg} / \mathrm{L}$ as $\mathrm{N})$ & 0.0007 \\
00095 & Specific conductance, field $\left(\mu \mathrm{S} / \mathrm{cm}\right.$ at $\left.25^{\circ} \mathrm{C}\right)$ & 1 \\
00010 & Temperature, water field $\left({ }^{\circ} \mathrm{C}\right)$ & 0.1 \\
63680 & Turbidity, monochrome near infrared LED light, $780-900$ nanometers, detection & 0.1 \\
& angle $90 \pm 2.5^{\circ}$, nephelometric turbidity units & \\
\hline
\end{tabular}


Table 3. Location of sediment cores in the estuary and fringing marsh, date of core collection, and vegetation at coring sites in Bass Harbor Marsh, Mount Desert Island, Maine.

[Figure 5 shows locations of coring sites by core identifier number; ${ }^{\circ}$, degrees; ${ }^{\prime}$, minutes; ", seconds]

\begin{tabular}{lcccc}
$\begin{array}{c}\text { Core identification } \\
\text { number }\end{array}$ & Latitude & Longitude & Collection date & Vegetation \\
\hline & \multicolumn{4}{c}{ Estuary } \\
\hline BHM.01 & $44^{\circ} 15^{\prime} 27.4^{\prime \prime}$ & $68^{\circ} 20^{\prime} 39.1^{\prime \prime}$ & $9 / 1 / 2009$ & Sparse Ruppia maritima \\
BHM.02 & $44^{\circ} 15^{\prime} 49.1^{\prime \prime}$ & $68^{\circ} 20^{\prime} 45.7^{\prime \prime}$ & $9 / 1 / 2009$ & Sparse Ruppia maritima \\
BHM.03 & $44^{\circ} 15^{\prime} 19.8^{\prime \prime}$ & $68^{\circ} 20^{\prime} 46.8^{\prime \prime}$ & $9 / 2 / 2009$ & Sparse Ruppia maritima \\
BHM.04 & $44^{\circ} 15^{\prime} 21.2^{\prime \prime}$ & $68^{\circ} 20^{\prime} 36.3^{\prime \prime}$ & $9 / 2 / 2009$ & Sparse Ruppia maritima \\
\hline \multicolumn{5}{c}{ Marsh surface } \\
\hline BHM.S1 & $44^{\circ} 15^{\prime} 27^{\prime \prime}$ & $68^{\circ} 20^{\prime} 35^{\prime \prime}$ & $11 / 2 / 2011$ & Dense Spatina patens \\
BHM.S2 & $44^{\circ} 14^{\prime} 36^{\prime \prime}$ & $68^{\circ} 20^{\prime} 43^{\prime \prime}$ & $11 / 2 / 2011$ & Spatina patens \\
BHM.S3 & $44^{\circ} 15^{\prime} 35^{\prime \prime}$ & $68^{\circ} 20^{\prime} 46^{\prime \prime}$ & $11 / 3 / 2011$ & Spatina patens \\
BHM.S4a & $44^{\circ} 15^{\prime} 27^{\prime \prime}$ & $68^{\circ} 20^{\prime} 32^{\prime \prime}$ & $11 / 3 / 2011$ & Spatina patens \\
BHM.S4b & $44^{\circ} 15^{\prime} 27^{\prime \prime}$ & $68^{\circ} 20^{\prime} 32^{\prime \prime}$ & $11 / 3 / 2011$ & Spatina patens \\
\hline
\end{tabular}


Table 4. Summer nutrient budget data for Bass Harbor Marsh estuary in Mount Desert Island, Maine, in 2011 and 2012.

[n/a, not available; $\mathrm{NH}_{4}-\mathrm{N}$, ammonium as nitrogen, $\mathrm{NO}_{3}-\mathrm{N}$; nitrate as nitrogen; TDN, total dissolved nitrogen; TDP, total dissolved phosphorus; TON, total organic nitrogen]

\begin{tabular}{|c|c|c|c|c|c|c|}
\hline \multirow{2}{*}{$\begin{array}{c}\text { Component of Nutrient } \\
\text { Budget }\end{array}$} & \multirow{2}{*}{ Exchange $^{1}$} & \multicolumn{5}{|c|}{ Nutrient budget data, in kilograms } \\
\hline & & $\mathrm{NH}_{4}-\mathrm{N}$ & $\mathrm{NO}_{3}-\mathrm{N}$ & TDN & TDP & TON \\
\hline \multicolumn{7}{|c|}{$2011(5 / 24 / 2011$ to $9 / 27 / 2011)$} \\
\hline Watershed runoff & Input & 50 & 110 & 1,200 & 26 & 1,000 \\
\hline Direct precipitation & Input & 6.3 & 26 & $\mathrm{n} / \mathrm{a}$ & $\mathrm{n} / \mathrm{a}$ & $\mathrm{n} / \mathrm{a}$ \\
\hline Flood tide & Input & 650 & 380 & 2,600 & 480 & 1,600 \\
\hline Ebb tide & Export & 560 & 270 & 3,400 & 530 & 2,600 \\
\hline Residual $^{2}$ & Net & 150 & 250 & 400 & -24 & 0 \\
\hline \multicolumn{7}{|c|}{$2012(5 / 22 / 2012$ to $9 / 25 / 2012)$} \\
\hline Watershed runoff & Input & 84 & 170 & 2,600 & 63 & 2,300 \\
\hline Direct precipitation & Input & 8.6 & 30 & $\mathrm{n} / \mathrm{a}$ & $\mathrm{n} / \mathrm{a}$ & $\mathrm{n} / \mathrm{a}$ \\
\hline Flood tide & Input & 640 & 230 & 1,500 & 470 & 630 \\
\hline Ebb tide & Export & 770 & 200 & 3,500 & 490 & 2,500 \\
\hline Residual $^{2}$ & Net & -37 & 230 & 400 & 36 & 230 \\
\hline
\end{tabular}

${ }^{1}$ Exchange refers to the direction of nutrient load with respect to the estuary. Loads are inputs to the estuary, exports from the estuary, or the net exchange (sum of inputs minus sum of exports).

${ }^{2}$ The residual is with respect to the estuary during a sequential flood followed by ebb tide and is calculated as follows: Residual $=($ flood + watershed runoff + direct precipitation $)-$ ebb. If the residual is positive, then inputs to the estuary were greater than exports, implying consumption within the estuary (uptake, absorption, or flocculation/sedimentation). If the residual is negative, then exports from the estuary are greater than inputs, implying that the estuary is a net source to the ocean. 
Table 5. Projected changes in estuary area and in water volume associated with 50-, 100-, and 200centimeter sea-level rise at mean higher high water and mean lower low water at Bass Harbor Marsh estuary, Mount Desert Island, Maine.

[NAVD 88, North American Vertical Datum of 1988; n/a, not available; cm, centimeter; SLR, sea-level rise]

\begin{tabular}{|c|c|c|c|c|c|}
\hline Condition & $\begin{array}{c}\text { NAVD } 88 \\
\text { elevation (meters) }\end{array}$ & $\begin{array}{c}\text { Area inundated } \\
\text { (hectares) }\end{array}$ & $\begin{array}{c}\text { Increase in } \\
\text { area (percent) }\end{array}$ & $\begin{array}{c}\text { Estuary volume } \\
\text { (cubic meters) }\end{array}$ & $\begin{array}{c}\text { Increase in } \\
\text { volume (percent) }\end{array}$ \\
\hline \multicolumn{6}{|c|}{ Mean higher high water } \\
\hline Current condition & 1.226 & 25.7 & $\mathrm{n} / \mathrm{a}$ & 176,000 & $\mathrm{n} / \mathrm{a}$ \\
\hline 50-cm SLR & 1.526 & 50.8 & 98 & 279,000 & 59 \\
\hline 100-cm SLR & 1.826 & 77.5 & 202 & 473,000 & 169 \\
\hline 200-cm SLR & 2.426 & 136 & 430 & $1,130,000$ & 543 \\
\hline \multicolumn{6}{|c|}{ Mean lower low water } \\
\hline Current condition & 0.727 & 21.6 & $\mathrm{n} / \mathrm{a}$ & 56,800 & $\mathrm{n} / \mathrm{a}$ \\
\hline 50-cm SLR & 1.027 & 24.1 & 12 & 126,000 & 122 \\
\hline 100-cm SLR & 1.327 & 26.7 & 24 & 203,000 & 257 \\
\hline 200-cm SLR & 1.927 & 89.7 & 315 & 559,000 & 834 \\
\hline
\end{tabular}


Table 6. Historical changes in estuary channel and marsh areas based on geo-referenced aerial photographs, Bass Harbor Marsh estuary, Mount Desert Island, Maine.

[ha, hectares; n/a, not available]

\begin{tabular}{|c|c|c|c|c|}
\hline \multirow[b]{2}{*}{ Year } & \multicolumn{2}{|c|}{ Estuary channel } & \multicolumn{2}{|c|}{ Marsh surface } \\
\hline & $\begin{array}{l}\text { Area } \\
\text { (ha) }\end{array}$ & $\begin{array}{c}\text { Cumulative } \\
\text { percentage } \\
\text { change }\end{array}$ & $\begin{array}{l}\text { Area } \\
\text { (ha) }\end{array}$ & $\begin{array}{c}\text { Cumulative } \\
\text { percent } \\
\text { change }\end{array}$ \\
\hline 1944 & 19.1 & $\mathrm{n} / \mathrm{a}$ & 26.3 & $\mathrm{n} / \mathrm{a}$ \\
\hline 1955 & 20.1 & 5.03 & 25.9 & -1.33 \\
\hline 1979 & 20.2 & 5.87 & 25.8 & -1.94 \\
\hline 1997 & 20.4 & 6.93 & 25.5 & -3.08 \\
\hline 2010 & 20.5 & 7.07 & 25.4 & -3.11 \\
\hline
\end{tabular}


Table 7. Summary of total sediment mass accumulation rates (MAR) and sedimentation rates for the cores collected from the estuary in 2009 at Bass Harbor Marsh, Mount Desert Island, Maine.

[Figure 5 shows locations of coring sites by core identifier number. $\mathrm{cm} / \mathrm{yr}$, centimeters per year; g/ $\mathrm{cm}^{2} / \mathrm{yr}, \mathrm{grams}$ per square centimeter per year; --, not measured]

\begin{tabular}{|c|c|c|c|c|c|c|c|c|}
\hline \multirow{3}{*}{$\begin{array}{l}\text { Sampling } \\
\text { dates }\end{array}$} & \multicolumn{8}{|c|}{ Core identifier number } \\
\hline & \multicolumn{2}{|c|}{ BHM.01 } & \multicolumn{2}{|c|}{ BHM.02 } & \multicolumn{2}{|c|}{ BHM.03 } & \multicolumn{2}{|c|}{ BHM.04 } \\
\hline & Total $^{1}$ & ORG1 & Total1 & ORG1 & Total1 & ORG1 & Total $^{1}$ & ORG1 \\
\hline \multicolumn{9}{|c|}{ Mass accumulation rate (MAR g/cm²/yr) } \\
\hline 1980-2009 & 0.11 & 0.017 & 0.09 & 0.014 & 0.1 & 0.015 & 0.09 & 0.014 \\
\hline $1960-1980$ & 0.09 & 0.013 & 0.06 & 0.01 & 0.09 & 0.012 & 0.07 & 0.012 \\
\hline $1930-1960$ & 0.04 & 0.006 & 0.04 & 0.006 & 0.05 & 0.007 & 0.04 & 0.006 \\
\hline pre-1930 & 0.02 & 0.002 & -- & -- & 0.03 & 0.004 & 0.02 & 0.004 \\
\hline \multicolumn{9}{|c|}{ Sedimentation rate at surface $(\mathrm{cm} / \mathrm{yr})$} \\
\hline 1980-2009 & 0.5 & -- & 0.4 & -- & 0.4 & -- & 0.5 & - \\
\hline $1960-1980$ & 0.4 & -- & 0.3 & -- & 0.3 & -- & 0.4 & - \\
\hline $1930-1960$ & 0.2 & -- & 0.2 & -- & 0.2 & -- & 0.2 & - \\
\hline pre-1930 & 0.1 & -- & -- & -- & 0.1 & -- & 0.1 & - \\
\hline
\end{tabular}

${ }^{1}$ Total represents the total sediment mass accumulation rate. ORG represents the organic matter mass accumulation rate. 
Table 8. Summary of sediment mass accumulation rates (MAR), for the cores collected from the marsh surface in 2011 at Bass Harbor Marsh, Mount Desert Island, Maine.

[Figure 5 shows sites of collection of sediment cores. $\mathrm{cm} / \mathrm{yr}$, centimeters per year; CRS, constant rate of supply lead$210\left({ }^{210} \mathrm{~Pb}\right)$ isotope dating method; ${ }^{137} \mathrm{Cs}$, cesium-137 isotope; $\mathrm{Bq} / \mathrm{cm}^{2}$, becquerels per square centimeter; $\mathrm{g} / \mathrm{cm}^{2} / \mathrm{yr}$, grams per square centimeter per year; --, not measured; $\mathrm{Pb}$; lead]

\begin{tabular}{|c|c|c|c|c|c|c|c|c|}
\hline $\begin{array}{c}\text { Site (core } \\
\text { identification } \\
\text { number) }\end{array}$ & $\begin{array}{c}\text { Unsupported } \\
210 \mathrm{~Pb} \\
\text { inventory } \\
\mathrm{Bq} / \mathrm{cm}^{2}\end{array}$ & $\begin{array}{l}\text { Dated } \\
\text { range, } \\
\text { from year } \\
\text { shown to } \\
2011\end{array}$ & $\begin{array}{l}\text { Accretion } \\
\text { rate (cm/yr) }\end{array}$ & $\begin{array}{c}\text { Total } \\
\text { MAR } \\
\text { (g/cm²/yr) }\end{array}$ & $\begin{array}{c}\text { Organic } \\
\text { MAR } \\
\left(\mathrm{g} / \mathrm{cm}^{2} / \mathrm{yr}\right)\end{array}$ & $\begin{array}{c}\text { Inorganic } \\
\text { MAR } \\
\text { (g/cm²/yr) }\end{array}$ & $\begin{array}{l}{ }^{137} \text { Cs peak } \\
\text { depth }(\mathrm{cm})\end{array}$ & $\begin{array}{c}\text { CRS date } \\
\text { of }{ }^{137} \mathrm{Cs} \\
\text { peak }\end{array}$ \\
\hline BHM.S1 & 1.33 & 1902 & 0.22 & 0.036 & 0.015 & 0.0230 & $12-14$ & $1956-66$ \\
\hline BHM.S2 & 0.93 & 1912 & 0.14 & 0.023 & 0.015 & 0.0085 & $6-8$ & $1971-86$ \\
\hline BHM.S3 & 0.43 & 1916 & 0.15 & 0.018 & 0.014 & 0.0047 & double peak & -- \\
\hline BHM.S4a & 0.93 & 1903 & 0.20 & 0.024 & 0.017 & 0.0076 & $12-14$ & 1949-54 \\
\hline BHM.S4b & 0.77 & 1904 & 0.18 & 0.025 & 0.018 & 0.0068 & $8-10$ & 1965-80 \\
\hline Average & 0.88 & -- & 0.18 & 0.025 & 0.016 & 0.010 & -- & -- \\
\hline $\begin{array}{l}\text { Standard } \\
\text { deviation }\end{array}$ & 0.33 & -- & 0.03 & 0.007 & 0.002 & 0.007 & -- & -- \\
\hline
\end{tabular}


Table 9. Summary of sedimentation rates for the cores collected from the marsh surface at Bass Harbor Marsh, Mount Desert Island, Maine, in 2011.

[cm/yr, centimeters per year]

\begin{tabular}{llcccc}
\hline $\begin{array}{c}\text { Core } \\
\text { identification } \\
\text { number }\end{array}$ & $\begin{array}{c}\text { Location in } \\
\text { marsh }\end{array}$ & Years & $\begin{array}{c}\text { Accretion rate } \\
\text { (cm/yr) }\end{array}$ & Years & $\begin{array}{c}\text { Accretion rate } \\
\text { (cm/yr) }\end{array}$ \\
\hline BHM.S1 & East edge & $1980-2011$ & 0.29 & $1902-1948$ & 0.25 \\
BHM.S2 & West edge & $1979-2011$ & 0.21 & $1912-1948$ & 0.09 \\
BHM.S3 & East interior & $1981-2011$ & 0.22 & $1889-1934$ & 0.06 \\
BHM.S4a & West interior & $1983-2011$ & 0.20 & $1903-1936$ & 0.16 \\
BHM.S4b & West interior & $1981-2011$ & 0.26 & $1903-1951$ & 0.15 \\
\hline
\end{tabular}


Table 10. LOADEST-selected regression equations for the indicated tributary or tidal load.

[D, decimal time; $\mathrm{Ln}(\mathrm{Load})$, natural logarithm of load in kilograms of nitrogen or phosphorus per day; LnQ, centered natural logarithm of discharge; $\mathrm{NH}_{4}$, ammonium; $\mathrm{NO}_{3}$, nitrate; TDN, total dissolved nitrogen; TDP, total dissolved phosphorus]

\begin{tabular}{|c|c|c|}
\hline Site & Nutrient & Regression equation \\
\hline Marshall & $\mathrm{NO}_{3}$ & $\operatorname{Ln}($ Load $)=-0.4074+0.9551 \mathrm{LnQ}$ \\
\hline Marshall & $\mathrm{NH}_{4}$ & $\operatorname{Ln}($ Load $)=-2.0709+0.9864 \mathrm{LnQ}$ \\
\hline Marshall & TDN & $\operatorname{Ln}(\operatorname{Load})=0.7389+1.1070 \operatorname{LnQ}+0.1069 \operatorname{Sin}(2 \pi \mathrm{D})+0.4811 \operatorname{Cos}(2 \pi \mathrm{D})+0.0857 \mathrm{D}$ \\
\hline Marshall & TDP & $\operatorname{Ln}($ Load $)=-2.8749+1.1972 \operatorname{LnQ}+0.3608 \operatorname{Sin}(2 \pi \mathrm{D})+0.5789 \operatorname{Cos}(2 \pi \mathrm{D})+-0.0934 \mathrm{D}$ \\
\hline Heath & $\mathrm{NO}_{3}$ & $\operatorname{Ln}($ Load $)=-4.2265+0.9565 \mathrm{LnQ}+-0.2331 \mathrm{D}$ \\
\hline Heath & $\mathrm{NH}_{4}$ & $\operatorname{Ln}(\operatorname{Load})=-3.1486+0.9222 \mathrm{LnQ}$ \\
\hline Heath & TDN & $\operatorname{Ln}($ Load $)=-0.8361+0.9144 \operatorname{LnQ}+0.1911 \operatorname{Sin}(2 \pi \mathrm{D})+0.8362 \operatorname{Cos}(2 \pi \mathrm{D})+0.1109 \mathrm{D}$ \\
\hline Heath & TDP & $\operatorname{Ln}(\operatorname{Load})=-5.6194+0.8368 \mathrm{LnQ}+0.1047 \mathrm{LnQ}^{2}+-0.5848 \operatorname{Sin}(2 \pi \mathrm{D})+1.5329 \operatorname{Cos}(2 \pi \mathrm{D})$ \\
\hline Lurvey & $\mathrm{NO}_{3}$ & $\operatorname{Ln}($ Load $)=-5.7385+0.5069 \operatorname{LnQ}+0.1269 \operatorname{Sin}(2 \pi \mathrm{D})+-0.6736 \operatorname{Cos}(2 \pi \mathrm{D})$ \\
\hline Lurvey & $\mathrm{NH}_{4}$ & $\operatorname{Ln}($ Load $)=-4.7318+0.9714 \mathrm{LnQ}$ \\
\hline Lurvey & TDN & $\operatorname{Ln}($ Load $)=-4.0347+0.9818 \mathrm{LnQ}+0.1043 \mathrm{D}$ \\
\hline Lurvey & TDP & $\operatorname{Ln}($ Load $)=-8.3393+0.9415 \operatorname{LnQ}+0.0049 \mathrm{LnQ}^{2}+-0.0296 \operatorname{Sin}(2 \pi \mathrm{D})+-0.9511 \operatorname{Cos}(2 \pi \mathrm{D})+-0.0839 \mathrm{D}$ \\
\hline Adams & $\mathrm{NO}_{3}$ & $\operatorname{Ln}(\mathrm{Load})=-3.1438+-0.9551 \mathrm{LnQ}$ \\
\hline Adams & $\mathrm{NH}_{4}$ & $\operatorname{Ln}($ Load $)=-1.0541+0.9864 \mathrm{LnQ}$ \\
\hline Adams & TDN & $\operatorname{Ln}(\operatorname{Load})=1.4875+1.1070 \mathrm{LnQ}+0.1069 \operatorname{Sin}(2 \pi \mathrm{D})+0.4811 \operatorname{Cos}(2 \pi \mathrm{D})+0.0857 \mathrm{D}$ \\
\hline Adams & TDP & $\operatorname{Ln}(\operatorname{Load})=-2.1580+1.1972 \mathrm{LnQ}+0.3608 \operatorname{Sin}(2 \pi \mathrm{D})+0.5789 \operatorname{Cos}(2 \pi \mathrm{D})+-0.0934 \mathrm{D}$ \\
\hline Estuary ebb & $\mathrm{NO}_{3}$ & $\operatorname{Ln}(\operatorname{Load})=2.4681+1.5625 \mathrm{LnQ}+-0.0237 \mathrm{LnQ}^{2}+-0.1073 \operatorname{Sin}(2 \pi \mathrm{D})+2.3916 \operatorname{Cos}(2 \pi \mathrm{D})+-0.4133 \mathrm{D}+1.2413 \mathrm{D}^{2}$ \\
\hline Estuary ebb & $\mathrm{NH}_{4}$ & $\operatorname{Ln}($ Load $)=2.0396+1.4788 \mathrm{LnQ}+-0.3784 \mathrm{LnQ}^{2}+0.3530 \operatorname{Sin}(2 \pi \mathrm{D})+0.8555 \operatorname{Cos}(2 \pi \mathrm{D})+-0.2778 \mathrm{D}$ \\
\hline Estuary ebb & TDN & $\operatorname{Ln}(\operatorname{Load})=4.2954+0.7242 \mathrm{LnQ}+-0.1492 \operatorname{Sin}(2 \pi \mathrm{D})+1.4370 \operatorname{Cos}(2 \pi \mathrm{D})$ \\
\hline Estuary ebb & TDP & $\operatorname{Ln}(\operatorname{Load})=0.4224+1.0853 \mathrm{LnQ}+-0.3744 \operatorname{Sin}(2 \pi \mathrm{D})+-0.9329 \operatorname{Cos}(2 \pi \mathrm{D})+-0.0956 \mathrm{D}$ \\
\hline Estuary flood & $\mathrm{NO}_{3}$ & $\operatorname{Ln}($ Load $)=3.6606+0.9869 \mathrm{LnQ}+-0.4095 \operatorname{Sin}(2 \pi \mathrm{D})+2.4833 \operatorname{Cos}(2 \pi \mathrm{D})+-0.5450 \mathrm{D}$ \\
\hline Estuary flood & $\mathrm{NH}_{4}$ & $\operatorname{Ln}($ Load $)=2.6201+0.8738 \mathrm{LnQ}$ \\
\hline Estuary flood & TDN & $\operatorname{Ln}(\operatorname{Load})=4.7289+0.5668 \mathrm{LnQ}+0.0093 \mathrm{LnQ}^{2}+-0.4195 \operatorname{Sin}(2 \pi \mathrm{D})+0.6814 \operatorname{Cos}(2 \pi \mathrm{D})+-0.5397 \mathrm{D}+-1.9252 \mathrm{D}^{2}$ \\
\hline Estuary flood & TDP & $\operatorname{Ln}($ Load $)=2.1645+1.0037 \mathrm{LnQ}+-0.2666 \operatorname{Sin}(2 \pi \mathrm{D})+-0.2811 \operatorname{Cos}(2 \pi \mathrm{D})$ \\
\hline
\end{tabular}


Table 11. Number of observations and selected model statistics from LOADEST regression model runs.

$\left[\mathrm{B}_{\mathrm{P}} \%\right.$, load bias in percent; $\mathrm{E}$, Nash-Sutcliffe efficiency index; $\mathrm{NO}_{3}$, nitrate; $\mathrm{NH}_{4}$, ammonium; $\mathrm{R}^{2}$, regression model correlation coefficient; TDN, total dissolved nitrogen; TDP, total dissolved phosphorus]

\begin{tabular}{|c|c|c|c|c|c|}
\hline Site & Nutrient & $\begin{array}{c}\text { Number of } \\
\text { observations }\end{array}$ & $\mathbf{R}^{2}$ & $\mathrm{E}$ & Bp\% \\
\hline Marshall & $\mathrm{NO}_{3}$ & 16 & 0.82 & 0.907 & -11.7 \\
\hline Marshall & $\mathrm{NH}_{4}$ & 16 & 0.92 & 0.954 & 10.0 \\
\hline Marshall & TDN & 20 & 0.97 & 0.990 & -4.64 \\
\hline Marshall & TDP & 13 & 0.99 & 0.998 & -2.72 \\
\hline Heath & $\mathrm{NO}_{3}$ & 17 & 0.67 & 0.753 & 5.30 \\
\hline Heath & $\mathrm{NH}_{4}$ & 17 & 0.86 & 0.956 & 9.48 \\
\hline Heath & TDN & 22 & 0.89 & 0.978 & -0.98 \\
\hline Heath & TDP & 14 & 0.94 & 0.994 & -2.30 \\
\hline Lurvey & $\mathrm{NO}_{3}$ & 15 & 0.86 & 0.773 & -23.5 \\
\hline Lurvey & $\mathrm{NH}_{4}$ & 15 & 0.95 & 0.969 & 14.2 \\
\hline Lurvey & TDN & 21 & 0.99 & 0.988 & 6.54 \\
\hline Lurvey & TDP & 16 & 0.99 & 0.996 & -5.22 \\
\hline Adams & $\mathrm{NO}_{3}$ & 16 & 0.82 & 0.907 & -11.7 \\
\hline Adams & $\mathrm{NH}_{4}$ & 16 & 0.92 & 0.954 & 10.0 \\
\hline Adams & TDN & 20 & 0.97 & 0.990 & -4.64 \\
\hline Adams & TDP & 13 & 0.99 & 0.998 & -2.72 \\
\hline Estuary ebb & $\mathrm{NO}_{3}$ & 97 & 0.86 & 0.795 & 6.13 \\
\hline Estuary ebb & $\mathrm{NH}_{4}$ & 99 & 0.74 & 0.283 & 18.9 \\
\hline Estuary ebb & TDN & 134 & 0.46 & 0.426 & -1.98 \\
\hline Estuary ebb & TDP & 135 & 0.89 & 0.812 & 0.339 \\
\hline Estuary flood & $\mathrm{NO}_{3}$ & 68 & 0.54 & 0.029 & 5.36 \\
\hline Estuary flood & $\mathrm{NH}_{4}$ & 68 & 0.44 & 0.246 & 2.75 \\
\hline Estuary flood & TDN & 73 & 0.30 & 0.427 & 1.79 \\
\hline Estuary flood & TDP & 74 & 0.87 & 0.787 & 0.69 \\
\hline
\end{tabular}


Table 12. Mean loads and associated 95-percent confidence intervals based on the chosen adjusted maximum likelihood estimate regression model for tributary or tidal fluxes.

$[\mathrm{kg} / \mathrm{d}$, kilograms of nitrogen or of phosphorus per day; TDN, total dissolved nitrogen; TDP, total dissolved phosphorus; \%, percent]

\begin{tabular}{|c|c|c|c|c|c|c|}
\hline \multirow[b]{3}{*}{ Site } & \multirow[b]{3}{*}{ Nutrient } & \multirow{3}{*}{$\begin{array}{l}\text { Mean } \\
(\mathrm{kg} / \mathrm{d})\end{array}$} & \multicolumn{4}{|c|}{ 95-Percent confidence intervals } \\
\hline & & & \multicolumn{2}{|c|}{ Lower } & \multicolumn{2}{|c|}{ Upper } \\
\hline & & & $\mathrm{kg} / \mathrm{d}$ & $\begin{array}{c}\text { Percenta } \\
\text { ge of } \\
\text { mean }\end{array}$ & $\mathrm{kg} / \mathrm{d}$ & $\begin{array}{c}\text { Percenta } \\
\text { ge of } \\
\text { mean }\end{array}$ \\
\hline \multirow[t]{4}{*}{ Marshall Brook } & Nitrate & 1.06 & 0.48 & 55 & 2.06 & 94 \\
\hline & Ammonium & 0.19 & 0.12 & 37 & 0.30 & 58 \\
\hline & TDN & 5.73 & 3.80 & 34 & 8.30 & 45 \\
\hline & TDP & 0.13 & 0.09 & 31 & 0.18 & 38 \\
\hline \multirow[t]{4}{*}{ Heath Brook } & Nitrate & 0.0174 & 0.00428 & 75 & 0.0486 & 179 \\
\hline & Ammonium & 0.0542 & 0.00346 & 94 & 0.0810 & 49 \\
\hline & $\mathrm{TDN}$ & 1.10 & 0.73 & 34 & 1.59 & 45 \\
\hline & TDP & 0.01537 & 0.007937 & 48 & 0.02699 & 76 \\
\hline \multirow[t]{4}{*}{ Lurvey Brook } & Nitrate & 0.003728 & 0.001982 & 47 & 0.006411 & 72 \\
\hline & Ammonium & 0.02783 & 0.01496 & 46 & 0.04811 & 73 \\
\hline & TDN & 0.55 & 0.39 & 29 & 0.76 & 38 \\
\hline & TDP & 0.01349 & 0.008819 & 35 & 0.01978 & 47 \\
\hline \multirow[t]{4}{*}{ Adams Brook } & Nitrate & 0.05 & 0.02 & 60 & 0.10 & 100 \\
\hline & Ammonium & 0.54 & 0.33 & 39 & 0.83 & 54 \\
\hline & TDN & 12.11 & 8.03 & 34 & 17.54 & 45 \\
\hline & TDP & 0.26 & 0.18 & 31 & 0.36 & 38 \\
\hline \multirow[t]{4}{*}{ Estuary ebb 2011} & Nitrate & 2.69 & 2.29 & 15 & 3.13 & 16 \\
\hline & Ammonium & 5.63 & 4.49 & 20 & 6.97 & 24 \\
\hline & TDN & 27.37 & 24.09 & 12 & 30.95 & 13 \\
\hline & TDP & 5.36 & 5.05 & 6 & 5.67 & 6 \\
\hline \multirow[t]{4}{*}{ Estuary ebb 2012} & Nitrate & 2.17 & 1.81 & 17 & 2.57 & 18 \\
\hline & Ammonium & 7.88 & 6.14 & 22 & 9.96 & 26 \\
\hline & $\mathrm{TDN}$ & 29.88 & 26.00 & 13 & 34.18 & 14 \\
\hline & TDP & 4.63 & 4.25 & 8 & 5.05 & 9 \\
\hline \multirow[t]{4}{*}{ Estuary flood 2011} & Nitrate & 5.98 & 4.02 & 33 & 8.55 & 43 \\
\hline & Ammonium & 10.5 & 8.7 & 17 & 12.55 & 20 \\
\hline & $\mathrm{TDN}$ & 46.91 & 30.91 & 34 & 75.59 & 61 \\
\hline & TDP & 7.43 & 6.97 & 6 & 7.92 & 7 \\
\hline \multirow[t]{4}{*}{ Estuary flood 2012} & Nitrate & 3.88 & 2.83 & 27 & 5.21 & 34 \\
\hline & Ammonium & 10.34 & 8.53 & 18 & 12.41 & 20 \\
\hline & $\mathrm{TDN}$ & 28.29 & 18.8 & 34 & 40.93 & 45 \\
\hline & TDP & 7.15 & 6.70 & 6 & 7.63 & 7 \\
\hline
\end{tabular}


Prepared by the Pembroke Publishing Service Center

For more information concerning this report, contact:

Office Chief

U.S. Geological Survey

New England Water Science Center

Maine Office

196 Whitten Road

Augusta, ME 04330

dc_me@usgs.gov

or visit our Web site at:

http://me.water.usgs.gov/ 
3

$\frac{9}{9}$

言

훙

ํํㄹ

C

올

옴

음

$\stackrel{\circ}{\circ}$

क

京

嗯

폰

윽

종

罗

ํㅗํ

宽 